\title{
Het meten en managen van klant-organisatie relaties
}

Citation for published version (APA):

Schijns, J. M. C. (1998). Het meten en managen van klant-organisatie relaties. [Doctoral Thesis, Maastricht University]. Universiteit Maastricht. https://doi.org/10.26481/dis.19990114js

Document status and date:

Published: 01/01/1998

DOI:

10.26481/dis.19990114js

Document Version:

Publisher's PDF, also known as Version of record

\section{Please check the document version of this publication:}

- A submitted manuscript is the version of the article upon submission and before peer-review. There can be important differences between the submitted version and the official published version of record.

People interested in the research are advised to contact the author for the final version of the publication, or visit the DOI to the publisher's website.

- The final author version and the galley proof are versions of the publication after peer review.

- The final published version features the final layout of the paper including the volume, issue and page numbers.

Link to publication

\footnotetext{
General rights rights.

- You may freely distribute the URL identifying the publication in the public portal. please follow below link for the End User Agreement:

www.umlib.nl/taverne-license

Take down policy

If you believe that this document breaches copyright please contact us at:

repository@maastrichtuniversity.nl

providing details and we will investigate your claim.
}

Copyright and moral rights for the publications made accessible in the public portal are retained by the authors and/or other copyright owners and it is a condition of accessing publications that users recognise and abide by the legal requirements associated with these

- Users may download and print one copy of any publication from the public portal for the purpose of private study or research.

- You may not further distribute the material or use it for any profit-making activity or commercial gain

If the publication is distributed under the terms of Article $25 \mathrm{fa}$ of the Dutch Copyright Act, indicated by the "Taverne" license above, 


\section{HET METEN EN MANAGEN VAN}

KLANT-ORGANISATIE RELATIES 
(c) 1298, Jos M.C. Schijins, Maastricht

All rights reserved. No part of this publication may be reprinted or utilized in any form or by any electronic, mechanical or other means, now known, or hereafter invented, including photocopying and recording, or in any information storage or retrieval system, without written permission from the copyright owner.

ISBN: $\quad 90-9012249-4$

Trefw: relatiemarketing relatiesterkte direet marketing klantenclub

Druk: Datawyse Boekprodukties, Maastricht 


\title{
HET METEN EN MANAGEN VAN KLANT-ORGANISATIE RELATIES
}

\author{
PROEFSCHRIFT.
}

ter verkrijging van de graad van doctor aan de Universiteit Maastricht, op gezag wan de Rector Magnificus, Prof. dr. A.C. Nieuwenhuijzen Kruseman, volgens het besluit van het College van Decanen, in het openbaar te verdedigen op donderdag 14 januari 1999 on 14.00 uur

$$
\text { door }
$$

Jozef Maria Christiaan Schijns 


\section{PROMOTOR:}

Prof. dr. J.D.P. Kasper

\section{CO-PROMOTOR:}

Dr. J.G.A.M. Lemmink

\section{BEOORDELINGSCOMMISSIE:}

Prof dr. G.A. Pfann (voorzitter)

Prof. dr. J.C. Hoekstra (Rijksuniwersiteit Groningen / Erasmus Universiteit Rotterdam) Dr. C.F. W. Pahud de Mortanges

Financièle en/or materiele steun werd verleend door:

R\&M, Research and Marketing b.v te Maastricht

Gulpener Bierbrouwerij b.v. te Gulpen

Gall \& Gall te Hoofddorp 


\section{WOORD VOORAF}

Ondanks dat een proefschrif in eerste instantie een individueet werksuk heet te zijn is het onmogelijk zo'n werkstuk tot een goed ainde te brengen zonder de onvoorwaardelijke steum van anderen. De sterkte van de relaties die met deze mensen onderhouden worden, heeft er toe geleid dat dit proefschrift wollooid werd. Hun onwoorwardelike vertrouwen in mij als promovendus en in het onderwerp van mijn proefschrift, de overstapkosien van het niet voltooien van het proefschrift en de attractiviteit van het wel voltooien ervan, hebben ertoe geleid dat het proefschrift over het meten en managen van klant-organisatie relaties uiteindelyk kon worden afgerond!

Tot degenen die een directe, inhoudelijke bijdrage aan het proefschrift hebben geleverd, dienen in eerste instantie promotor prof dr. Hans Kasper en co-promotor dr. Jos Lemmink gerekend te worden. Ik dank hen voor de geboden gellegenheid en vrijheid me te verdiepen in het onderwerp wan dit proefschrift. Daamaast wist ik me de afgelopen jaren gesteund door een aantal verstandige helpers. In chronologische volgorde wil ik noemen de (voomalige) studentassistenten Susan Haafkes-Jansen, Katja van Schie, Pascal Peeters, Nicole Fleischeuer en Ronald Paulissen. Naast bovengenoemde personen gat mijn dank eveneens uit naar die collega's (zowel intern als extern), die interesse toonden in het onderzoek en bereid waren mij, gevraagd of ongevraagd, van commentaar te voorzien.

Dank ook aan de studenten, niet alleen zij die in de afgelopen jaren hebben deelgenomen aan de cursus 'Relationship Marketing and Direct Marketing Management', maar ook de diverse stagiaires en afgestudeerden die ik heb mogen begeleiden. Zij zorgden veelal voor frisse, onbevangen benaderingen en belichten soms de door mij onderbelichte aspecten. Van dic afstudeerders wil ik hier in het bijzonder Gaby Odekerken-Schröder noemen. Samen met haar werd, in de vorm van een pilot-studie, de basis voor dit proefschrift gelegd.

De enorme last van het veldwerk werd aanzienlijk verlicht door de medewerking van $\mathbb{R} \& M$, Research and Marketing b.w. R\&M nam het complete veldwerk voor haar rekening. Mijn dank gaat daarbij met name uit naar drs. Piet Nelissen en drs. Wil Nelissen.

Mijn dank gaat ook nit naar de Culpener Bierbrouworij b.v., met name drs. Paul Ruticn en dhr. Henk Meijers, alsmede naar Gall \& Gall, met name dhr. Erik Visser. Beide organisalies stelden hun klantenbestanden ter beschikking teneinde hun klanten gericht te kumen benaderen woor het onderzoek.

Tot slot hebben ook de leden van de beoordelingscommissie, te weten prof. dr. Gerard Plann, prof. dr. Janny Hoekstra en dr. Charles Pahud de Mortanges, inhoudelijk bijgedragen door hel manuscript nauwgezet te bestuderen en van commentaar te voorzien. In het bijzonder prof. dr. Janny Hoekstra, met wie ik reeds jaren op een bijzonder prettige nanier mag samenwerken, ben ik zeer erkentelijk woor hat inbreng.

Met de personen die indirect bij (de inhoud van) het proelschrift betrokken zijn, heb ik in het algemeen het meest directe, intense en durzame contack Zij die zich mogelijk hot minst realiseren een bijdrage te hebben geleverd aan dit proefschrift zijn de clubleden wan Hei-Sei-Do sport. Zij hebben mij in staat gesteld de juiste balans te bewaren respectievelijk te herkrijgen tussen lichaam en geest. En op momenten dat die balans tijdelijk verstoord was, hebben zij (en ik) dat letterlijk aan den lijve moeten ondervinden. In het bijzonder wil ik hicr mijn dank uitspreken voor sensei Karel Langen. Door zijn specifieke kijk op de maatschappij in het 
algemeen en op de judosport in het bijzonder is hij niet alleen op, maar ook buiten 'de mat' als een bijzonder leemeester te kenschetsen. Onder zijn begeleiding heb ik ook op sportief vlak promotic mogen maken.

Jeugdwiend Will Somers vormi voor mij het overtuigende bewijs dat een sterke relatie niet per definitie gepard hoeft te gaan met een hoge (bezoek)frequentie, maar wel met wederzijds vertrotwen.

Tot hen dic het proces, dat tot dit proefschrift heeft geleid, intensief hebben meebeleefd behoren zonder enige twijfel mijn ouders en schoonouders: beide paren onderhouden inmiddels meer dan 40 jaren ean huwelijksrelatie en fungeren daamee uitstekend als referentiekader voor mijn studie. Zij stonden altijd woor me klaar en toonden begrip indien dat omgekeerd niet altijd hat geval bleek to zijn. Voor hen heb ik enorm veel respect en waardering.

Mijn grootste dank en respect gaxa echter uil naar Miriam. Miriam, voor mij staat vast dat jouw onverbiddelijke steun en onbegrensde vertrouwen in een goede afloop ertoe hebben bijgedragen dat het proefschrift met het beoogde resultaat kan worden afgerond. Hoewel je hier als latste genoend wordt, verdien je mijn meeste waardering. Ik realiseer mij terdege dat ik dankzij jou dit proefschrift heb kunnen voltooien. Jij creëerde alle mogelijkheden voor mij om me te kunnen concentreren op deze studie, maar bleef zelf altijd in de schaduw staan. Daarwoor heb ik enorm veel bewondering en wardering. Eindelijk kun je nu de tastbare vrucht van je onuitputtelijke investeringen, opofferingen, inspanning en soms ook frustratie aanschouwen. De warde van jouw steun die ik heb mogen ondervinden en jouw wertrouwen in een goede afloog gedurende het gehele proces is niet in woorden uit te drukken. Aan jou en aan mijn ouders draag ik dit proefschrift op.

Jos Schijns

november 1998, Wijlre 


\section{INHOUDSOPGAVE}

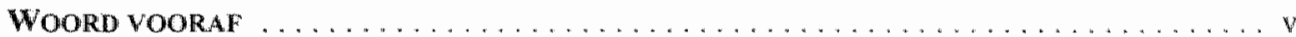

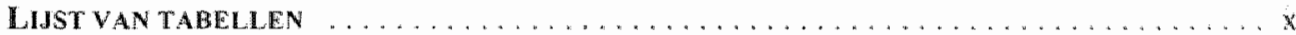

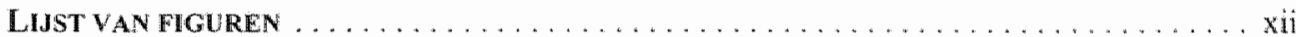

\section{HOOFDSTUK 1 : INLEIDING}

1.1 Aanleiding tot het onderzoek $\ldots \ldots \ldots \ldots \ldots \ldots \ldots \ldots \ldots \ldots \ldots \ldots$

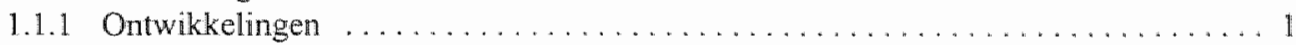

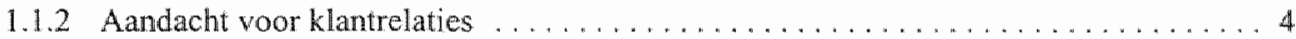

1.2 Probleemstelling . . . . . . . . . . . . . . . . . . . . . . 5

1.3 Belang, afbakening en positionering van het onderzoek . . . . . . . . . . . 6

1.4 Opbouw van het proefschrift $\ldots \ldots \ldots \ldots \ldots \ldots \ldots \ldots \ldots \ldots \ldots \ldots$

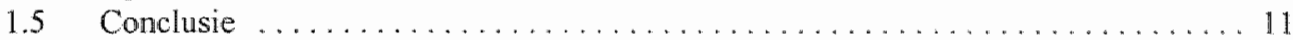

\section{HOOFOSTUK 2: RELATIEMARKETING}

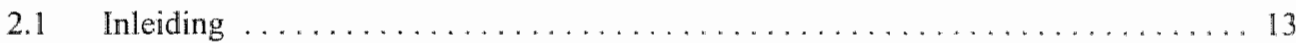

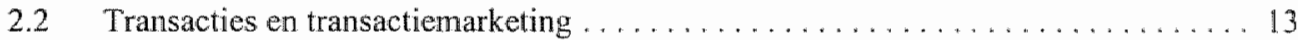

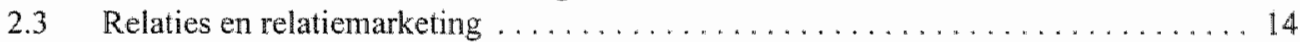

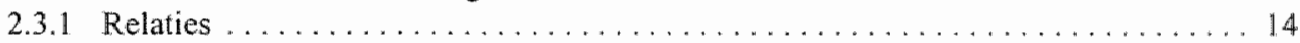

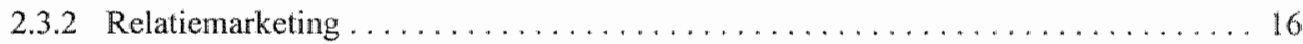

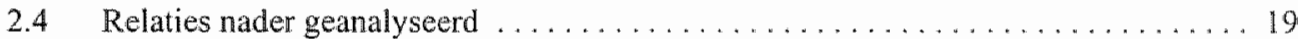

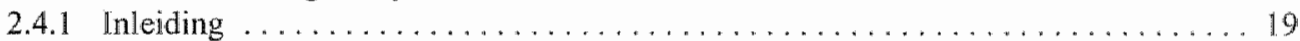

2.4.2 De prestatiedimensie en de persoonsdimensie . . . . . . . . . . . . . . . . . 19

2.4.3 De gedragsdimensie en de belevingsdimensie $\ldots \ldots \ldots \ldots \ldots \ldots \ldots \ldots \ldots \ldots$

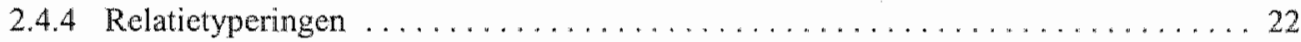

2.5 Het relatie- en marketingstrategie continuüm $\ldots \ldots \ldots \ldots \ldots \ldots \ldots \ldots \ldots \ldots$

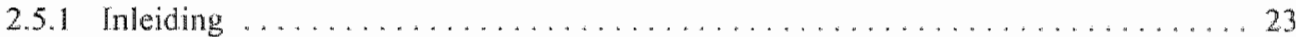

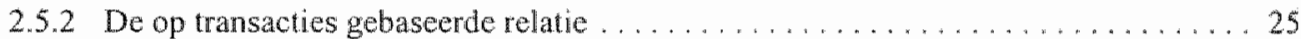

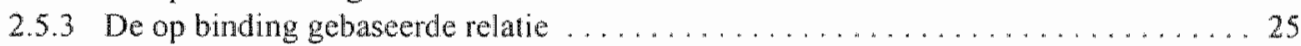

2.5 .4 Aard binding . . . . . . . . . . . . . . . . . . . . . . . . . . 26

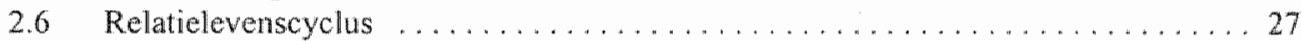

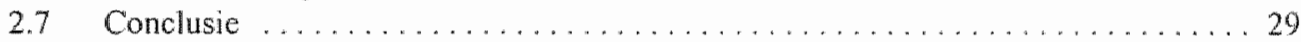

HOOFDSTUK 3: RELATIEMARKETING: STRATEGISCHE EN INSTRUMENTELE INVULLING

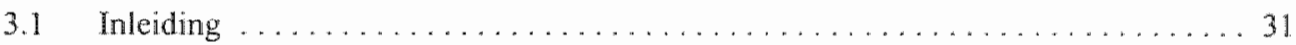

3.2 Direct Marketing: inhoud en niveaus $\ldots \ldots \ldots \ldots \ldots \ldots \ldots \ldots \ldots \ldots \ldots$

3.3 Relatiemarketing en direct marketing . . . . . . . . . . . . . . . . . . 35

3.4 Relatienarketingprogramma's . . . . . . . . . . . . . . . . . . 36

3.5 Klantenclubs . .................................... 40

3.5 .1 Definiëring . . . . . . . . . . . . . . . . . . . . . . . . . . 40

3.5.2 Redenen voor het oprichten van een klantenclub . . . . . . . . . . . . . 40

3.6 Conclusie . . . . . . . . . . . . . . . . . . . . . . . . 41 
wiii

HOOFDSTUK 4: HET METEN YAN RELATIESTERKTE: DE DESTAANDE THEORIE

4.1 Inleidirig

4.2 Altematieven woor het meten wan relatiesterkte $\ldots \ldots \ldots \ldots \ldots \ldots \ldots \ldots \ldots \ldots . \ldots . \ldots$

4.2 .2 Indicatoren

4.2.3 Relationship commitment $(\mathrm{RC})$ en de relationship commitment questionnaire (RCQ) 47

4.3 Segmerteren, beschrijven en monitoren van relaties .................... 50

4.4 Hel verklaren van relatiesterkte: een model . . . . . . . . . . . . . . . . . . . . . 62

4.4.1 Selectieproces: de procedure ............................. 62

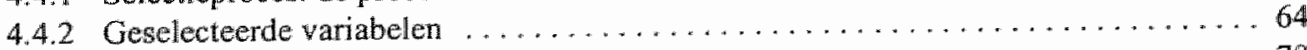

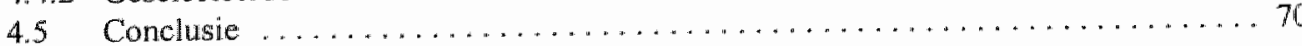

\section{HOOFDSTUK 5: OPZET EN UITVOERING VAN HET ONDERZOEK}

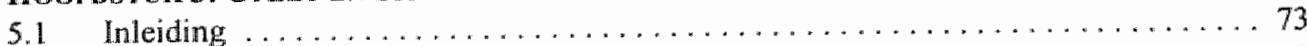

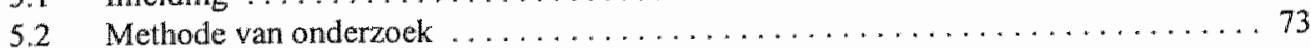

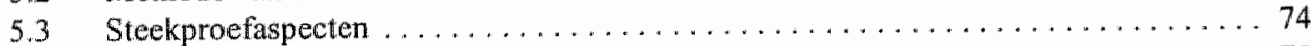

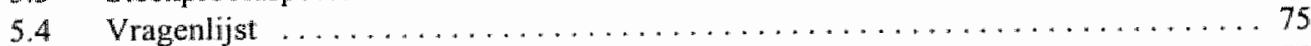

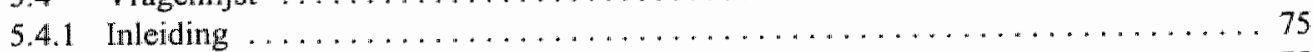

5.4 .2 Vo\|gorde en typering van de vragen en lengte van de vragenlijst $\ldots \ldots \ldots \ldots \ldots \ldots 75$

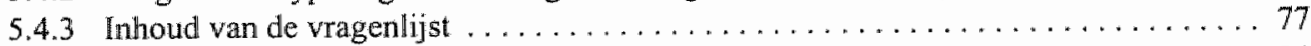

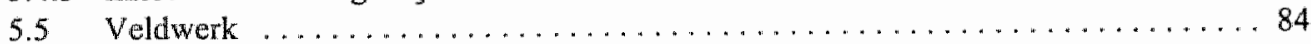

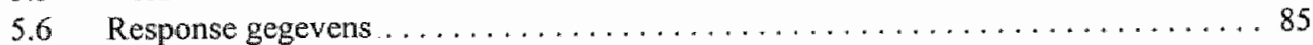

5.7 Profielen van de respondenten $\ldots \ldots \ldots \ldots \ldots \ldots \ldots \ldots \ldots \ldots \ldots \ldots \ldots$

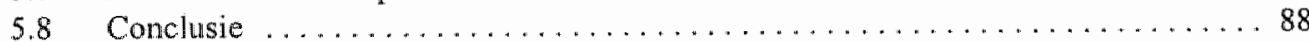

HoOfDSTUK 6: ANALYSE VAN GeGeVENS

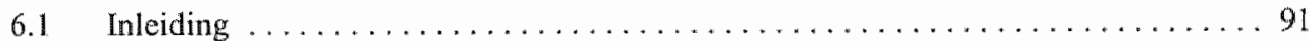

6.2 Resultaten Gulpener studie $\ldots \ldots \ldots \ldots \ldots \ldots \ldots \ldots \ldots \ldots \ldots \ldots \ldots \ldots \ldots$

62.1 Inleiding . . . . . . . . . . . . . . . . . . . . . . . . . . . 91

6.2 .2 Loyaliteit . . . . . . . . . . . . . . . . . . . . . . . . . . 92

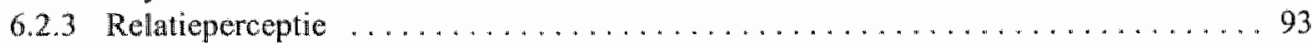

6.2 .4 Het RLM-model voor de Gulpener studie . . . . . . . . . . . . . . . . . . . . 99

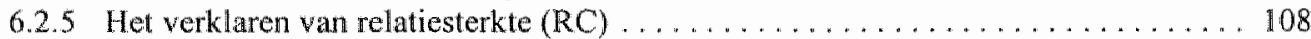

6.3 Resultaten Gall \& Gall studie . . . . . . . . . . . . . . . . . . . . . . 113

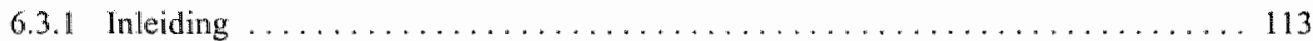

6.3 .2 Loyaliteit . . . . . . . . . . . . . . . . . . . . . . . . . . . 113

6.3 .3 Relatieperceptie ................................ 114

6.3 .4 Het RLM-model voor de Gall \& Gall studie $\ldots \ldots \ldots \ldots \ldots \ldots \ldots \ldots \ldots \ldots \ldots \ldots$

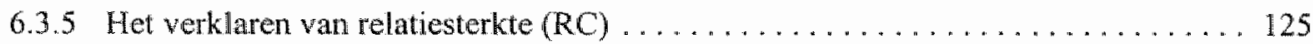

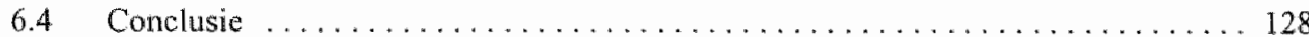


HOOFDSTUK 7: CONCLUSIES, IMPLICATIES EN SUGGESTIES VOOR VERDER ONDERZOEK

$7.1 \quad$ Inleiding . . . . . . . . . . . . . . . . . . . . . . . 133

7.2 Conclusies en implicaties ten aanzien van de onderzoeksvragen . . . . . . . . . . 133

7.2.1 Conclusie en implicaties betreffende het meten van relatiesterkte . . . . . . . . 133

7.2.2 Conclusie en implicaties betreffende het gebruik van de relationship commitment

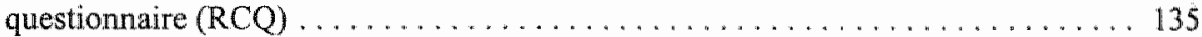

7.2.3 Conclusie en implicaties betreffende het beïnvloeden van relatiesterkte . . . . . . . 139

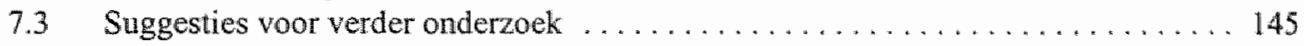

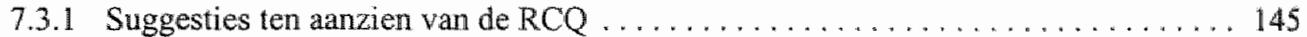

7.3.2 Suggesties ten aanzien van het RLM-model $\ldots \ldots \ldots \ldots \ldots \ldots \ldots \ldots \ldots . \ldots \ldots$

7.3.3 Suggesties ten aanzien van het model ter verklaring van relatiesterkte $\ldots \ldots \ldots 152$

BIJlage 1: VRAGENLIIJST TEN BEHOEVE VAN DE GULPENER STUdie $\ldots \ldots \ldots \ldots \ldots 155$

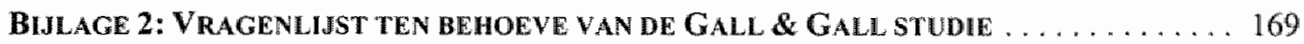

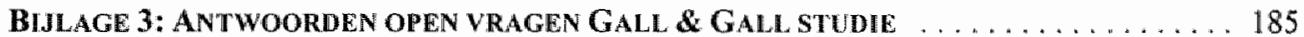

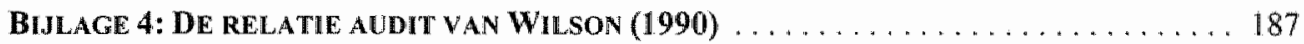

BiJlage 5: De Organizational Commitment Questionnaire (OCQ) . . . . . . 189

BIJLAGE 6: VERGELIJKING RESPONDENTEN IN HET KADER VAN SELECTION BIAS ALS

GEVOLG VAN ITEM NON-RESPONSE $\ldots \ldots \ldots \ldots \ldots \ldots \ldots \ldots \ldots \ldots \ldots \ldots$

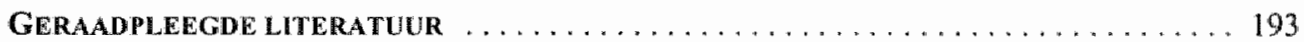

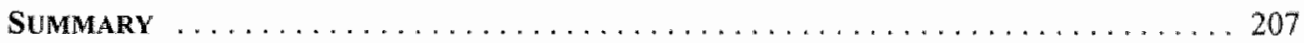

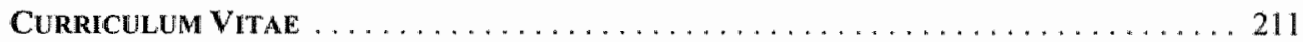




\section{LIJST VAN TABELLEN}

2.1 Overzicht van auteurs die zowel en prestatiedimensie als cen persoonscimensie binnen een relatie onderkennen

2.2 Overzicht van auteurs die zowel een gedragsdimensie als een belevingsdimensie binnen een relatie onderkennen

2.3 Typen relaties naar aanleiding van het onderscheid in prestatie- en persoonsdimensie . 22

2.4 Typen relaties naar anleiding van het onderscheid in gedrag en beleving ........ 23

2.5 Vergelijking tussen de kenmerken van transactie-respectievelijk relatiemarketing . . . 30

3.1 Indelingen, karakteristieken en woorbeelden van relatiemarketingprogramma's ...... 39

5.1 Vragen die transactie-informatie verschaffen $\ldots \ldots \ldots \ldots \ldots \ldots \ldots \ldots \ldots \ldots \ldots \ldots$

5.2 Vragen die contact-informatie verschaffen $\ldots \ldots \ldots \ldots \ldots \ldots \ldots \ldots \ldots \ldots \ldots$

5.3 Vragen die de beleving van de relatie meten $\ldots \ldots \ldots \ldots \ldots \ldots \ldots \ldots \ldots \ldots \ldots$

5.4 Items van de Relationship Commitment Questionnaire . . . . . . . . . . . . . 83

5.5 Vragen die profielgegevens van de respondenten verschaffen . . . . . . . . . . 83

5.6 Overzicht steekproefgegevens Gulpener studie en Gall \& Gall studie ... . . . . . . 86

6.1 Transactie-informatic: feitelijk koopgedrag . . . . . . . . . . . . . . . . . . 93

6.2 De Relationship Commitment Questionnaire (RCQ) . . . . . . . . . . . . . 94

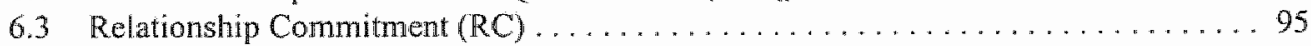

6.4 Principale Componenten Analyse op de negen items van de $\mathrm{RCQ} \ldots \ldots \ldots \ldots$

6.5 Overzicht Cronbach alpha waarden voor de variabelen: gepercipieende overstapkosten, vertrouwen en alternatief commitment . . . . . . . . . . . 97

6.6 Beleving van de relatie: samengestelde variabelen $\ldots \ldots \ldots \ldots \ldots \ldots \ldots \ldots$

6.7 Pearson correlaties $(r)$ tussen RC enerzijds en het alternatieve commitment construct, overstapkosten, attractiviteit, tevredenheid en vertrouwen anderzijds

6.8 Verdeling van leden, ex-leden en potentiële loden van het Gulpener Biergilde over de vier cellen van het RLM-model . . . . . . . . . . . . . . . . . . . 101

6.9 Waarden voor $\mathrm{RC}, \mathrm{RFM}$ en vergelijking van segmenten voor leden . . . . . . . . 102

6.10 Procentuele bestedingen en vergelijking van segmenten voor leden ......... 102

6.11 Waarden woor $\mathrm{RC}$, RFM en vergelijking van segmenten voor ex-leden ........ 103

6.12 Procentuele bestedingen en vergelijking van segmenten voor ex-leden ........ 104

6.13 Waarden voor RC, RFM en wergelijking van segmenten voor potentiële leden „... 105

6.14. Procentuele bestedingen en vergelijking van segmenten voor potentiêle leden . . . 106

6.15 Pearson correlatie-coéfficiënten voor attractiviteit, overstapkosten en vertrouwen. . 109

6.16 Transactie-informatie: feitelijk koopgedrag . . . . . . . . . . . . . . . 113

6.17 De Relationship Commitment Questionnaire (RCQ) . . . . . . . . . . . . 114

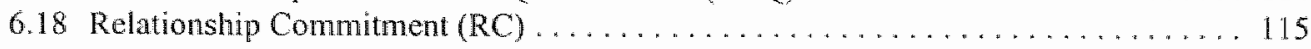

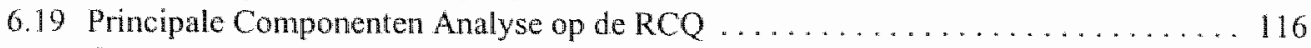

6.20 Overzicht Cronbach alpha waarden voor de variabelen: gepercipieerde overstapkosten, vertrouwen en tevredenheid $\ldots \ldots \ldots \ldots \ldots \ldots \ldots \ldots \ldots \ldots$

6.21 Beleving van de relatie: samengestelde variabelen $\ldots \ldots \ldots \ldots \ldots \ldots \ldots \ldots \ldots \ldots$

6.22 Pearson correlaties $(r)$ tussen RC enerzijds en overstapkosten, attractiviteit, tevredenheid en vertrouwen anderzijds

6.23 Verdeling van leden en ex-leden van het Gall \& Gall wijnkaarthoudersprogramma over de vier cellen van het RLM-model . . . . . . . . . . . . . . . . . . . 120

6.24 Waarden voor $\mathrm{RC}$, RFM en vergelijking van segmenten voot leden . . . . . . . 121 
6.25 Procentuele bestedingen en vergelijking van segmenten voor leden . . . . . . . 122

6.26 Waarden voor RC, RFM en vergelijking van segmenten voor ex-leden ... . . . . 123

6.27 Procentuele bestedingen en vergelijking van segmenten voor ex-leden ........ 123

6.28 Pearson correlatie-coëfficiẻnten voor attractiviteit, overstapkosten en vertrouwen... 126

BI Open vraag 2: Waarom geen houder meer? .................... 185

BII Open vraag 4: Waarom houder geworden? .................... 185 


\section{LIJST VAN FIGUREN}

1.1 Ontwikkelingen aan vraag - en aanbodzijde, die van invloed zij.jn op de marketing- en communicatiestrategie van een ondememing . . . . . . . . . . . . . . . . . 3

1.2 Schematische weergave van de opbouw van dit proefschnift ............. 11

2.1 Tien relatievomen $\ldots \ldots \ldots \ldots \ldots \ldots \ldots \ldots \ldots \ldots \ldots \ldots \ldots \ldots \ldots$

2.2 A. Het relatiecontinutim

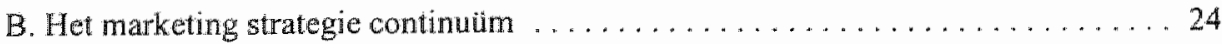

2.3 De loyaliteitsladder . . . . . . . . . . . . . . . . . . . . . . . 28

3.1 Het verband tussen relatiemarketing, direct marketing en klantenclub . . . . . . . . 36

3.2 De klantenclub als instrument ten behoeve van een direct marketing strategie,

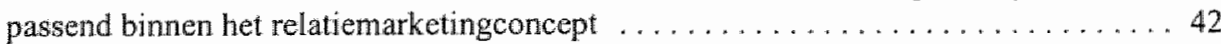

4.1 De relatieportfolio volgens Wilson $(1990) \ldots \ldots \ldots \ldots \ldots \ldots \ldots \ldots \ldots \ldots \ldots$

4.2 De Relationship Type Matrix van Krapfel et al. (1991) . . . . . . . . . . . . . . . 53

4.3 De Klant-Relatie Matrix volgens Hoekstra (1998) . . . . . . . . . . . . . . . . 54

4.4 De "relationship strength matrix' van Strandvik en Liljander (1994b) . . . . . . . . 56

4.5 De "Relative Attitude-Behavior Relationship' van Dick en Basu (1994) . . . . . . . 57

4.6 De Relatieperceptie en Loyaliteit Matrix . . . . . . . . . . . . . . . . . . . . . . . . 59

4.7 Relatiesterkte als afhankelijke van tevredenheid, vertrouwen, gepercipieerde overstapkosten en attractiviteit . ... . . . . . . . . . . . . . . . . . . . . . 69 69

6.1 Het RLM-model voor leden van het Gulpener Biergilde . . . . . . . . . . . . . . . 101

6.2 Het RLM-model voor ex-leden van het Gulpener Biergilde . . . . . . . . . . . 103

6.3 Het RLM-model voor potentiële leden van het Gulpener Biergilde . . . . . . . . . 105

6.4 Samenvatting resultaten betreffende het RLM-model voor de Gulpener studie . . . . 107

6.5 Het RLM-model voor houders van de Gall \& Gall wijnkaart . . . . . . . . . . . 121

6.6 Het RLM-model voor ex-houders wan de Gall \& Gali wijnkaart . . . . . . . . . . . 122

6.7 Samenvatting resultaten betreffende het RLM-model voor de Gall \& Gall studie ... 124

7.1 Management implicaties voortvloeiend uit het RLM-model . . . . . . . . . . . . . 142

7.2 Positionering van het Gall \& Gall wijnkaarthoudersprogramma (voordeelprogramma) en van het Gulpener Biergilde (clubprogramma) ten opzichte van een geïntegreerd relatiemarketingprogramma op basis van emotionele en rationele clubvoordelen . . 144

7.3 Het RLM-model aangevuld met de dimensie 'aard van de relatie' waarin een nader onderscheid gemakt wordt in affectief en calculatief commitment . . . . . . . 148

7.4 Een algemeen en uitgebreid onderzoeksmodel van de totstandkoming van een relatie 154 


\section{HOOFDSTUK 1: INLEIDING}

"Marketing's 'Dating Game" has evolved into a contmuing Love Comection" ".

Schlossberg (1989)

\subsection{AANLEIDING TOT HET ONDERZOEK}

\subsubsection{ONTWIKKELINGEN}

Bimen marketing heeft lang het transactiedenken centraal gestaan, warbij de winst op de transactie de drijfveer vormt van het zaken doen (Stom, 1991; Webster, 1992). Het realliseren van die winst wordt echter steeds moeilijker. Als gevolg daarvan verandert de ard van de relaties tussen bedrijf en afnemers: er vindt een verschuiving plaats van de andacht voor transacties, het werven van klanten en het denken in marktaandelen, naar de aandacht voor het opbouwen en onderhouden van rellaties, het behouden van klanten en het denken in termen van "customer share'. Deze verschuiving is aan te treffen in zowel de praktijk, als in de aandachtsvelden binnen de academische wereld (Hansen en Jeschke, 1992; Cannon en Sheth, 1994; Palmer, 1994a). Dit heeft ertoe geleid dat wij ons in dit proefschrift zullen bezig houden met de vraag op welke wijze deze relaties tussen klant en organisatie gemeten en "gemanaged" kunnen worden door de aambieder.

Voor de verschuiving van de aandacht voor transacties naar de aandacht voor relaties is een aantal redenen aan te geven. Ten eerste stellen technologische ontwikkelingen organisaties in staat op een efficiente wijze een grote variëteit in goederen en diensten te ontwerpen, te produceren en te promoten. Ontwikkelingen op het gebied van produkt- en produktietechnologie hebben tot een enorme toename in het aantal en de variëteit van goederen en diensten geleid. Dit biedt consumenten meer keuzemogelijkheden (McKenna, 1991; Barlow, 1992). Technologieën en hun toepassingen worden echter ook sneller gekopieerd, waardoor het onderscheid tussen concurrerende produkten geringer wordt (Hoekstra, 1994a). Uitgebreidere keuzemogelijkheden en minder onderscheid tussen produkten dragen ertoc bij dal consumenten gemakkelik vam aanbieder wisselen, waardoor de loyaliteit wordt aangetast (Rosenberg en Czepiel, 1984). De noodzaak on trouw te zijn dan wel te blijwen is dan immers niet zo erg groot, tenzij de aanbieder in staat is directe, structurele rellaties op te bouwen met de afnemers (Hoekstra, 1994a). Ontwikkelingen op het gebied van de informatietechnollogie bieden marketeers meer en betere mogelijkheden boodschappen te verzenden naar, en contact to onderhouden met, de individuele consument (Molenaar, 1993; Craig-Lees en Caldwell, 1994). Gebruik makend wan bestaande en nieuwe media leiden ontwikkelingen op het terrein van informatietechnologie tot meer interactic tussen aanbieders en afnemers (Hoekstra, 1994a; 1998). Consumenten worden daardoor blootgesteld aan een explosief toenemende hoeveelheid te verwerken gegevens. Daarmee wordt kiezen woor de consument ook moeilijker (Holzhater

1 Berry, 1983; Berry en Gresham, 1986; Kotler, 1988; Gromroos, 1989; Copulsky en Wolf, 1990; Anderson en Narus; 1991 b; Blattberg en Deighton, 1991; Christopher et al., 1991; MSl, 1991 ; Storm, 1991 ; Barlow, 1992; Webster, 1992; Molenaar, 1994; Parvatiyar en Sheth, 1994. 
an Zeitsen, $1993 \mathrm{c}$ ). "De consument $z$ al in toenemende mate bewust een keuze moeten maken welke informatie hij wel en welke hij niet wil gebruiken" (Bunt et aL, 1987, p. 28). Uit de geschetste technologische onwwkkelingen kan worden afgeleid dat veranderingen die op ons afkomen of die al gaande zinn, soms haaks op elkaar staan en zich bij sommige groepen in onze samenlewing wel en bij andere juist niet voordoen (Lakatos en Van Kralingen, 1985).

Ten tweede $z a l$, met name als gevolg van de verdergaande individualisering van de vraag, de samenleving uiteenvallen in allerlei groepen on subgroepen die bepalde dingen wel met elkar gemeen hebben, maar in andere opzichten weer sterk van elkaar verschillen. "Steeds duidelijker wordt dat massamarkten en homogeen gedrag zich minder vaak zullen manifesteren" (Lakatos en Van Kralingen, 1985, p. 45). "De consumenten gaan zich steeds minder als een uniforme groep en steeds meer als een groep individualisten gedragen" (Molenaar, 1993, p. 100). Daardoor word het ook steeds moeilijker om markten, aan de hand van tradicionele criteria, op te delen natr relevante segmenten (Bunt et al., 1987; Bunt en Tettero, 1987; Hockstra, 1994a). In plaats van segmentering van de markt is er in toenemende mate sprake van marktfragmentatie (Bunt et al., 1987; Shani en Chalasani, 1992; Holzhauer en Zeitsen, 1993d). Als gevolg daarvan leveren de traditionele (massa)benaderingen en universele reclameboodschappen in universele media steeds meer verspilling op en wordt het gewenste rendement niet (meer) gehaald. Marketeers hebben dan ook behoefte aan nieuwe benaderingen, aan meer efficiënte en meer effectieve manieren van communiceren (Lakatos en Van Kralingen, 1985; McKenna, 1991; Barlow, 1992; Naumann en Shannon, 1992; Shani en Chalasani, 1992; Webster, 1992). Het behouden wan klanten om redenen van effectiwiteit en elficiency verdient dan ook meer aandacht (Rosenberg en Czepiel, 1984; Ferguson en Brown, 1991). De kiosten van het werliezen van een klant en het werven van een nieuwe zijn relatief hoog (Craig-Lees en Caldwell, 1994; Berry, 1995). Marketinginspanningen gericht op bestaande klanten blijken een hoger rendement op te leveren dan de pogingen om nieuwe klanten te werven. Op basis van onderzoek is aangetoond dat het werven van een klant vijfkeer zo duur is dan het behouden wan een klant (Bunk, 1992; Naumann en Shannon, 1992; Alberts en Buitendijk, 1995a). Reichheld en Sasser (1990) en Reichheld (1996) tonen bovendien aan dat de winst sterk toeneemt indien een bedrijf er in slaagt het witreden wan klanten te beperken en dus de huidige klanten langer te behouden.

Als derde reden kan aangegeven worden dat de klant om een meer persoonlijke benadering en behandeling vaagl (Barlow, 1992; Molenar, 1994). Dit is mede een gevolg van de eerder genoende individualiseringstendens en marktfragmentatie. Ook ná de aankoop is het noodzaak goed voor de klant te (bljiven) zorgen teneinde ontewredenheid bij die klant te reduceren (Rosenberg en Czepiel, 1984). Het komt er steeds meer op neer dat het marketingproces feitelifk pas begint "After the sale is over..." (Levitt, 1983a).

Tot slot kan nog een aantal ontwikkelingen genoemd worden dat ertoe heeft bijgedragen dat de concurmentic in bepaalde sectoren van het bedrijfsleven intensiever is geworden en dat de noodzak tot het beschermen van het eigen klantenbestand verder onderstreept (Barlow, 1992; Berry, 1995; Sheth en Parvatiyar, 1995). Daarbij valt te denken aan ontwikkelingen als: de verdergaande intemationalisering, het verzadigen van markten, perioden van economische teruggang en veranderingen in het consumptiepatroon en bestedingsgedrag van consumenten.

Samenvattend geef figur 1.1 enkele van de voornatnste ontwikkelingen weer die van invloed zijn op de marketing-en communicatiestrategie van een onderneming. Ondememingen aan de aanbodzijde van de markt zien zich geplaatst voor de uitdaging om aan de wensen en behoeften aan de vraagzijde te voldoen. Nieuwe produkt(ie)technologieen stellen de fabrikanten in staat 
beter tegemoet te komen aan de vraag naar meer verschillende produkten. Andertijs stelt deze technologie de fabrikant in staat zijn produkten verder te differentioren en damme de vrang naar meer verschillende produkten verder te stimuleren. Informatietechnologie makt het aanbieders mogelijh beter aan de vraag naar persoonlike behandeling en communicatio tegemoet te komen.

$$
\text { vraagzijde }
$$

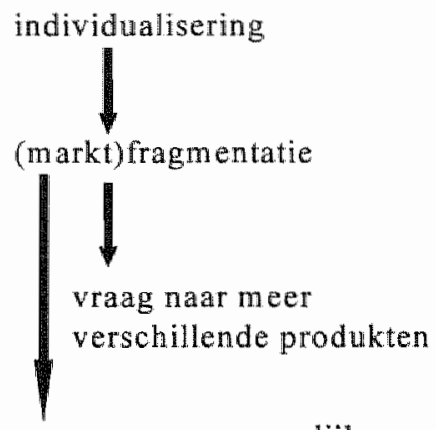

vraag naar persoonlijke behandeling en communicatie aanbodzijde

technologie

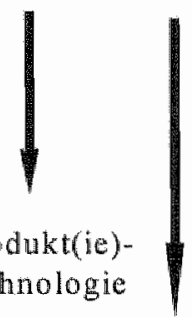

in formatietechnologie

Figuur 1.1 Ontwikkelingen aan vraag- en aanbodzijde, die van invloed zijn op de marketing- en communicatiestrategie van een onderneming

Ondernemingen zullen, onder andere op basis van markionderzoek en door middel van hun marketing-en communicatiestrategie, op deze ontwikkelingen moeten inspelen en "superior" customer value' aan de afnemers dienen te leveren, teneinde de concurrentieposilie van de organisatie te verdedigen (Treacy en Wiersema, 1993; Blijetiberg et al., 1996).

Treacy en Wiersema (1993) hebben een theorie ontwikkeld die aansluit bij de huidige ontwikkelingen bimen marketing. Daarbij ligt het accent minder op een vergelijking met de concurrentie (Porter, 1980; 1985), maar meer op de waarde die de klant ontlent aan de aanschaf of het gebruik van het produkt. Treacy en Wiersema stellen dat succesvolle ondermemingen zich onderscheiden door op minstens én van de volgende drie gebieden uit te blinken (zie ook Hoekstra, 1998):

- 'operational excellence': het leveren van betrouwbare goederen en/of diensten tegen concurrerende prjizen, geleverd met zo weinig mogelijk ongemak, onder meer le realiseren door het minmaliseren van overheadkosten en het optimaliseren van bedrijfsprocessen;

- "customer intimacy": het voortdurend aanpassen van goederen en/of diensten aan de wensen wan de klant op basis van gedetailleerde kennis van het individu, waardoor wordt voorzien in heterogene behoeften. Dit impliceer onder meer het investeren in cusiomer loyalty en 
directe communicatie. Daarbij krijgt de CLTV ${ }^{2}$ de voorkeur boven de waarde van een afzonderlijke transactie;

- "product leadership": voordurende innovatie op basis wan marktonderzoek ofwel geaggregeerde gegevens van de doelgroep, gebruikmakend van creativiteit en het snel commercialiseren van nicuwe ideeën bij grote groepen afnemers, onder meer via flexibele produktie en het verkorten van produktietijden.

In 'customer intimacy' staat het aangaan van directe relaties met afnemers centraal. In het bijzonder op deze worm van klantgerichtheid ten behoeve van het creëren van waarde voor de klant, wordt in dit proefschrift nader ingegaan, gelet op de eerder genoende verschuiving van de aandacht voor transacties naar de aandacht voot relaties met afnemers. Vandaar dat wij ons in dit proefschrift richten op (de) consequenties van de cerdergenoemde ongevingsontwikkelingen op de marketing-en communicatiestrategie(ën).

In de volgende paragraaf zal dieper ingegaan worden op de verschuiving binnen marketing van de aandacht voor transacties naar de andacht voor relaties met afnemers.

\subsubsection{AANDACHT VOOR KLANTRELATIES}

Demassificatie van onze samenleving in steeds meer groepen en subgroepen wraagt om een gediversificeerd beleid "waarbij meer en verschillende produkten worden aangeboden en innovatie en renovatie een belangrijke plaats zullen innemen. Daarnaast betekent demassificatie ook dat de marketingman ... zich ook weer moet gaan afvragen wat hij voor de consument kan betekenen" (Lakatos en Van Kralingen, 1985, p. 47). Meer en verschillende produkten leiden echter, zoals reeds eerder geconcludeerd werd, tot een keuzeprobleem bij de consument. "Het gevolg is dat consumenten een minder uitgesproken voorkeur krijgen voor een bepaalde produktvariëteit. Deze situatie wordt nog bemoeilijkt doordat produktlevenscycli steeds korter worden" (Peelen, 1990b, p. 9). Produktintroducties volgen elkaar sneller op, de terugverdienperiode wordt korter en aanbieders moeten zich in kortere tijd verzekerd weten van een voldoende winstgevend deel van de markt (Hoekstra, 1994a; 1998). Het gevaar bestaat dan dat bedrijwen geconfronteerd worden met een afname in klantenloyaliteit (McKenna, 1991; Ruekert, 1992). Dit hebben zij deels zelf geîntroduceerd door de toegenomen differentiatie in hun aanbod. Door meer keuzen zetten zij de klant zelf min of meer aan tot "switchen". Daardoor kan de aumbieder zich steeds minder verlaten op de eens zo trouwe klanten (Kreutzer, 1990). En dat terwiji het steeds korter worden van produktlevenscycli mede tot gevolg heeft dat de gedane investeringen in onderzoek en ontwikkeling (R\&D) steeds sneller moeten worden tengyerdiend. Om de strijd aan te binden met die bedreiging wordt - veelal via (her)positionering of via kortstondige sales promotion activiteiten als prijskortingen, premiums, monsters en refund acties - getracht die loyaliteit te herstellen. Ironisch genoeg heeft dit soort pogingen de loyaliteit van de consument te herstellen er juist toe bijgedragen dat consumenten aangemoedigd worden minder conservatief en meer avontuurlijk te zijn in hun koopgedrag. Door deze pogingen wordt de loyaliteit dus alleen maar verder ondermijnd (Otsmaa en Greenberg, 1989; Shani en Chalasani, 1992; Van Waterschoot en Van den Bulte, 1992; Hooper, 1997; Schriver, 1997).

\footnotetext{
2 De CLTV ('customer's lifetime value to the company") kan op meerdere manieren worden gedefinieerd. Peppers en Rogers (1993) omschrijwen het als de netto contante warde van alle toekomstige winsten die een klant mogelijk gaat opleveren.
} 
Hoe creèert en behoudt men dan wèl klantenloyaliteit, vragt Mckenna (199) zioh dan ook terecht af. Zelf beweert hij dat de echte oplossing nief in meer, maar in betere manketing gevonden kan worden. En dat betekent volgens hem dat marketing narar mogelijkheden moet zoeken de klant in de organisatie te integreren, door een relatie tussen de organisatie en de klant tot stand te brengen en deze relatie te continweren McKenna, 1991). McKemma beoogi hiermee aan te geven dat het habben van een sterk merk op zich onvoldoende waaborg bied voor omzet en continuïteit. Het opbouwen en onderhouden van een relatie fussen aanbieder en afnemer draagt bij aan een grotere merktrouw en kan als een mogelijkheid worden gezien om klanten tot herhalingsaankopen te bewegen (Peelen, 1990b).

Naast gevolgen voor de marketingstrategie in het algemeen hebben de in $\$ 1.1 .1$ genoende omgevingsontwikkelingen in het bijzonder gevolgen voor de efficiency en effectiviteit van de markelingcommunicatiestrategie.

"Demassificatie van de samenleving zal eveneens gevolgen hebben voor de manier warop reclamemakers met consumenten zullen gaan communiceren. ... Universele reclameboodschappen in universele media zullen steeds neer verspilling opleveren. De efficiency van massacommumicatie neemt (althans voor een deel) af" (Lakatos en Van Kralingen, 1985, p. $52)$.

Daarnaast hebben marktfragmentatie en de in aantal toegenomen soorten produkten en mediamogelijkheden bijgedragen aan een afname in effectiviteit van reclame: eenrichtings* communicatie en de traditionele massamediale beinvloeding verliezen hun effect (Naumann en Shannon, 1992; Alberts en Buitendijk, 1995a). "Groepjes kopers zullen met specifiek op hen gerichte boodschappen via speciaal op hen gerichte media bereikt moeten worden" (Gischler, 1988a, p. A1000-5). Bedrijven kunnen het zich niet langer veroorloven om met hagel te blijven schieten (Molenaar, 1993). Ook Webster (1992, p. 15) stelt dat "Impersonal, mass communications, especially media advertising, are becoming less effective, whereas personal, targeted, special purpose communications have become more important". Communicatie zal dus meer en meer direct dienen plaats te vinden (Hönig, 1990; McKenna, 1991). Dit suggereert dat bedrijven andere mechanismen gaan gebruiken om met hun afnemers te communiceren. Deze mechanismen zullen de mogelijkheid moeten bieden tot het onderhouden van meer individuele contacten (Bunt et $\mathrm{al}_{.}, 1987$ ) en dienen een conlinue interactie tussen marketers an afnemers met een constante uitwisseling van informatie mogelijk te maken (Alberts en Buitendij, 1995a). Direct mail, nieuwsbrieven en dectronische media zijn slechts enkolo voorbeelden van nieuwe technieken en mogelijkheden om toch efficiënt en effectief to operenen om de voorsprong op de concurrentie te behouden C.q. te bewerkstelligen (Gischler, 1988a).

De ontwikkelingen zoals die tot nog toe geschetst zijn en de gevolgen daarvan voor do marketing(communicatie)strategie uiten zich in een verschuiving van de andacht van transacties in de richting van relaties. (Schijns, 1994; 1996a) en vormden de aanleiding tot de in de volgende paragraaf geformuleerde probleemstelling.

\subsection{Probleemstelling}

Naar aanleiding van de in $\$ 1.1$ geschetste ontwikkelingen is het dus zinwol de overdaad aan (reclante)boodschappen in de massamedia te ontwijken en te kiezen woor rechtstreekse 
interactieve communicatie (Hockstra en Raaijmakers, 1992; Molcnaar, 1993). Interactieve communicatie is een belangrijk basiselement voor het opzetten van een werkzame en duurzame. marketingrelatie. Veel organisaties zijn zich er inmiddels van bewust geworden dat het in hum marketing(communicatie)strategie meer en meer gaat om het opbouwen, onderhouden en versterken van relaties mel (individuele) afnemers en dat hun strategie daar op gebaseerd moet zijn. Vervolgens concretiseren zij dit in diwerse activiteiten, zoals het oprichten wan een klantenclub, teneinde de relatie met hun afnemers te versterken of anders gezegd de mate van binding met hen te vergroten. Dergelijke activiteiten hebben in veel gevallen, in financieel opzicht, tot betere resultaten geleid. Onduidelijk is echter wat het effect van op relaties gerichte marketingstrategieen en -activiteiten is op een ander vaak genoemd doel van dergelijke strategieën en activiteiten, namelijk het versterken van de relatie: het vergroten van de mate van binding tussen aanbieder en afnemer. Dit komt met name omdat een duidelijk meetinstrument voor relatiesterkte nog ontbreekt (Peter, 1998). Vragen als: 'Ervaart de afnemer een sterke relatie?' of 'Ondervind hij een grote mate van binding?" kunnen derhalve (nog) niet afdoende beantwoord worder. Met andere woorden: de strategische onderbouwing voor en evaluatie wan bepaalde marketingbeslissingen gericht op het versterken van relaties ontbreekt nog.

De centrale vraag, waarop door middel van dit onderzoek getracht wordt een antwoord te vinden, luidt derhalve:

Hoe kan de sierkte van relaties (nate van binding) tussen consumenten en organisaties worden gemeten?

Om de noodzakelijke informatie te verkrijgen om bovenstaande centrale probleemstelling te kunnen beantwoorden, is een aantal onderzoeksvragen opgesteld:

1. Welke gegevens geven een indicatic van de sterkte van een relatie tussen (eind)afnemen: en aambieder en welke daarvan kumnen worden gebruikt in operationele zin voor de samenstelling van een instrument voor het meten van de relatiesterkte? $(\$ 4.2)$;

2. (hoe) kan het meetinstrument woor de rellatiesterkte gebruikt worden voor het segmenteren, beschijiven en monitoren van relaties? ( $\$ 4.3$ en hoofdstuk 6 ); en,

3. welke factoren spelen een rol bij het verklaren van relatiesterkte? ( $\$ 4.4$ en hoofdstuk 6 )

Het belang van het verkrijgen van een antwoord op de centrale probleemstelling zal in de volgende paragraal aangeduid worden.

\subsection{BELANG, AFBAKENING EN POSITIONERING VAN HET ONDERZOEK}

De klassieke marketingtheorie en -praktijk concentreren zich voomamelijk op het werven van nieuwe klanten, meer dan op het behouden van bestaande klanten (Kotler, 1994). Onder de geschetste nieuwe omstandigheden schiet deze zogenaamde klassieke marketing in hel algemeen tekort om een duurzaam concurrentievoordeel op te bouwen. Economen hanteren veelall een marktwom van volledige mededinging. Het succes voor een marketeer daarentegen ligt juist in het ontsnappen aan die volledige mededinging (Houston en Gassentheimer, 1987 ). 
Relaties hebben de potentie een duunam concurtentievoonded te crëren, indien de relaties bijdragen aan produktdifferentiatie en uitredingsbarrieres creeren (Day en Wensley, 1983; Dwyer et al., 1987; Poiesz en Van Raai, 1993). "Despite this potential, sellers commonly fail to see the necessity of managing their relationships with customers" (Dwyer et a1., 1987, p. 14; zie ook Goldberg, 1988). Relatienarketing tracht marketeers meet bewhst te laten worden van het belang van het managen van hun relaties met afnemers.

Veel van het empirische en theoretische onderzoek dat verricht wordt, richt zich cchter met name op relaties tussen organisaties ${ }^{3}$ en op relaties in de dienstverlening ${ }^{4}$. Tof nog toe is weing aandacht besteed aan relaties in de context van consumentengoederen voor individuele consumenten (Shani en Chalasani, 1992; Diller, 1994; Sirgy en Lee, 1994; Peterson, 1995). Dit ondanks het feit dat "as far as the marketing of consumer goods from the manufacturer to the ultimate consumers is concerned, there is a growing debate whether one can continue to apply marketing in the traditional mass marketing way" (Grönroos, 1994b, p. 354). Het enthousiasme voor toepassing van relatiemarketing is in consumentenmarkten minder dan in de andere genoende markten omdat het realiseren van relaties tussen aanbieder en consument word bemoeilijkt doordat (Peelen, 1990a):

- het bedrag dat een consument per transactic besteedt in verband met de aanschaf en het geof verbruik van huishoudelijke goederen en diensten veelal geen financiële rumte toelaat om de ontwikkeling van een duurzame, directe en interactieve relatie te bekostigen;

- het onderhouden van een relatie met een relatief groot aantal consumenten cen grote werkbelasting met zich mee brengt; en,

- de kosten van het vergaren van gegevens betreffende een relatief groot aantal consumenten en het vastleggen en bijhouden daarvan in een databestand vooralsnog vrij hoog zijn en een redelijk hoge marge op produkten vereisen (Blijenberg et al., 1996). Deze kosten zijn met name voor de "fast moving consumer goods" relatief hoog omdat adressemregistratie veelal (nog) geen onderdeel uitmaakt van het normale bedrijfsproces.

$\mathrm{Nu}$ het belang van relaties ook in consumentenmarkten en met name voor consumentengoederen sterker onderkend wordt, richt de aandacht zich, zowel in theorie als in praktijk, meer op de vraag hoe deze relaties opgebouwd, onderhouden en wersterkt kumen worden (Webster, 1992; Shetli en Parvatiyar, 1995; Peter, 1998). Het onderzock dat dartoo werricht is, is eclter woomamelijk praktijkgeorienteerd en mist een wetenschappelijktheoretische fundering van de verkregen resultaten (Bruhn en Bunge, 1994). Door relatiestoktc te definieren en te meten met een specifiek daarvoor ontwikkeld instrument, en te onderzoeken hoe deze sterkte verklaard kan worden, trachten wij middels ons onderzoek een wetenschappelijk fundament te ontwikkelen. Daartoe zal het empirisch deel van het onderzoek betrekking hebben op niet-duunzame verbruiksgoederen op de consumentenmarkt, de zogenaande 'fast mowing consumer goods' (fmcg). Hoewel deze studie zich dus in hoofdzak richt op de betrekkingen tussen particulieren (consumenten) en aanbieders van niet-duurzame

\footnotetext{
"Häkansson, 1982; Levitt, 1983a; Campbell, 1985; Jackson, 1985; Tumbull en Valla, 1986; Dwyer e1 at. 1987; Frazier et al., 1988; Kaufmamn en Stern, 1988; Anderson en Narus, 1990; Heide en John, 1992; Anderson en Weitz, 1992.
}

* Berry, 1983; Berry en Gresham, 1986; Crosby en Stephens, 1987; Gummessom, 1987b; Crosby ct al., 1990; Grönroos 1990 a; Venetis, 1997; de Ruyter et al., 1997. 
consumentengoederen, steunt zij sterk op literatuur op het gebied van zowel dienstennarketing als industriele marketing. Dit geldt in het bijzonder voor de engelstalige literatuur; in duistalige literaturu word namelijk wel relatief veel andacht besteed aan relatiemarketing in consumentenmarkten. Een aantal van onze hypothesen zal dan ook voortkomen uit ervaringen en bevindingen op het vakgebied wan zowel dienstverlening als industriele markien. We maken daxbij duidelijk dat die crvaringen en bevindingen ook opgaan voor consumentenmarkten.

Relatiesterkte moet bimen een bepalde context worden gemeten. Dat het empirisch deel van het onderzoek betrekking zal hebben op niet-duurzme verbruiksgoederen op de consumentenmarkt is daartoe nog te rum geformuleerd. Het empirische gedeelte van hel onderzoek wordt dan ook verder afgebakend door te kiczen voor de 'klantenclub' als marketinginstrument. Zo'n club word algemeen gezien als een middel om klanten te binden en de loyaliteit te verhogen. Ondememers investeren veelvuldig in dit soort klantenbindingssystemen (Gruen en Ferguson, 1994). Echter, de strategische onderbouwing voor dit soort investeringsbeslissingen ontbreekt veelal. Door rellatiesterkte te meten, de sterkte van de relatie voor verschillende klantengroepen net elkaar te vergelijken en te onderzoeken hoe deze sterkte verklaard kan worden, levert ons onderzoek cen bijdrage aan de strategische onderbouwing van op relatieversterking gerichte marketingstrategiebn en marketingactiviteiten in het algeneen en van klantenbindingssystemen in het bijzonder.

Vaak wordit bij het meten van de relatiesterkte gebruk gemaakt van gegevens betreffende het koopgedrag of de koopintentie. Binnen het vakgebied marketing wordt er veelal vanuit gegaan dat een klant die een sterke relatie percipieert, gelijk is aan een goede klant (0.a.: Peelen et al., 1989; Berry en Parasuraman, 1991; Liljander en Strandvik, 1994; Dowling en Uncles, 1997). Met behulp van ons special ontwikkelde instrument zijn we in stat om deze assumptie kritisch te evalueren.

Resumerend levert ons onderzoek de volgende bijdragen:

- willen de effecten van relatieversterkende maatregelen geevvalueerd worden, dan is het noodzakelijk te beschikken over een instrument dat de sterkte van de relatie op een walide en betrouwbare manier meet. Het atantal onderzoeken, gericht op het meten van rellatiesterkte, is echter gering en de wetenschappelijke theorievorming op dit terrein beperkt. Derhalve is het ontwikkelen vaty een meetinstrument op zich nodig en zinvol;

- een tweede bijdrage bestaat daaruit dat relatiesterkte gebrukt zal worden als segmentatiecritertum. Eerder werd opgemerkt dat als gevolg van individualisering en marktfragmentatie het steeds moeilijker wordt om markten, aan de hand van traditionele criteria, in te delen natar relevante segmenten. Relatiesterkte, zoals door ons gemeten, is een viet-traditioned criterium dat, in combinatie met traditionele criteria zoals koopgedraggegevens, tot nieuwe inzichten en verbeterde managenentimplicaties kan leiden; en,

- als relatiesterkte gemeten kan worden is het van belang te weten hoe relatiesterkte beinvloed kan worden leneinde daar de marketingstrategie en -activiteiten op af te stemmen. Derhalve wordt relatiesterkte tevens in een model opgenomen als te verklaren variabele. Als derde bijdrage geldt dat een beter inzicht geboden wordt in factoren die invloed kumen wiltoefenen op relatiesterkte. 
Teneinde tot het beoogde meetinstrument te komen is een theoretisch en empirisch onderzoek opgezet en vigevoerd. Van het theoretische gedeelte wordt in de hoofdstukken 2, 3 en 4 verslag gedaan, van het empirische gedeelte in de hoofdstukken 5 en 6 . Zie figur 1.2 voor een overzicht wan de indeling van dit proefschrift.

De methodologische aspecten van het empirisch onderzoek komen in hoofdstuk 5 nader ande orde, maar kunnen als volgt beknopt worden weergegeven. Het empirisch onderzoek onvat twee dwarsdoorsnede studies. Daarbij zijn primaire data verzameld door telefonisch zowel leden als niet-leden van twee klantenclubs te benaderen. Deze iwee klantenelubs zijn door woe aanbieders van 'fast moving consumer goods' (fmeg) in het leven geroepen: het Gulpener Biergilde is door de Gulpener Bierbrouwerij B.V. geintroduceerd, terwijl Gall \& Gall cen wijnkarthoudersprogramma introduceerde. De doot deze organisaties ten behoeve van hat onderzoek beschikbaar gestelde besianden met NAW-gegevens van leden w nit-leden fungeren als populatiekaders. In beide studies is gewerkt met steekproeven van nello 250 respondenten per bestand wan leden en niet-leden. Op basis van de verzamelde kwantitatieve gegevens is een aantal hypothesen getoetst. In deze 'multiple study, multiple sample' antak kumen individuele en groepen consumenten getraceerd worden die verschillan in de sterkte van de relatie met hun anbieder. Daamee bestaat de mogelikheid het voor het meten van rellatiesterkte gebruikte instrument te vallideren.

\subsection{OPBOUW VAN HET PROEFSCHRIFT}

In de hoofdstukken 2, 3 en $4 \mathrm{zal}$ een theoretisch raamwerk geschetst worden op basis van cen uitgebreide literatuurstudie. Daarin zal aandacht besteed worden aan achtercenvolgens: de concepten van transactiemarketing en relatiemarketing (hoofdstuk 2), direct marketing als marketingstrategie en de klantenclub als marketing instrument (hoofdstuk 3).

Transactiemarketing, ook wel traditionele marketing of klassieke marketing genoemd, omvat de marketing zoals gedefinieerd door de American Marketing Association: "Marketing is the process of planning and executing the conception, pricing, promotion, and distribution of ideas, goods, and services to create exchanges that satisfy individual and organizational objocheses" (Marketing News, 1985). In transactiemarketing stan de marketing-mix instrumcnten contral ten behoeve van het bewerkstelligen van mansaches met doelgroepelementen. Relatiemarketing daarentegen richt zich op het identificeren, opbouwen en onderhouden (en eventueel afbouwen) van relaties met individuen. De marketing-mix instrumenten zijn daarbij ondersteunend en minder dominant.

Direct Marketing wordt in hoofdstuk 3 gedefinieend als "een wom van marketing die bimen éen of meer produkt/marktcombinaties is gericht op het verkrijgen en onderhouden van directe relaties tussen een anbueder en de afnemers. De marketingactiviteiten zijn gebaseerd op kenmis van de individuele (potentiële) klanten. De marketinginstrumenten hebben een eigen speciliekc invulling. Het meest kenmerkend is het hanteren van directe communicatic entor directe levering" (Hoekstra en Schijns, 1997). Relatiemarketing en direct marketing hebben weliswaar, gegeven het streven naar individuele relaties, een vergelijkbare strokking, maar relatiemarketing besteedt nawwelijks aandacht aan de marketing-mix, in tegenstelling tol direct

\footnotetext{
${ }^{5}$ Naam, Adres en Woonplaats gegevens
} 
marketing (Hoekstra, 1998). Relatiemarketing geeft dan meer het concept, de idee weer vam waruit activiteiten worden verricht, terwijl direct marketing die verzameling activiteiten juisst specificert.

Het oprichten van een klantenclub door een aanbieder wordt gezien als een geschikte direct marketing activiteit on de tegelmatige uitwisseling van informatie met gebruikers, eem essentiee fundament voor een relatie, mogelijk te makern (Hönig, \990).

De hoofdstukken 2 en 3 schetsen de achtergrond voor het empinish onderzoek. In hoofdstuk: 4 wordt een instrument voot het meten van relatiesterkte ontwikkeld. Tevens wordt ingegaan opp de gebruiksmogelijkheden van dit meetinstrument voor relatiemanagement en -marketing doeleinden. Afnemers kunnen nu aan de hand van dit nieuwe meetinstrument worden gesegmenteerd op basis van enerzijds hun koopgedrag (gedragsdimensie) en anderzijds dle wijze waarop zij de relatie beleven in termen van relatiesterkte (belevingsdimensie). Eem andere gebruiksmogelijkheid van relatiesterkte heef betrekking op het meer gedetailleerd analyseren en beschrijven van relaties. Het zal blijken dat met name de wijze waarop dle belevingsdimensie geoperationaliseerd wordt, vernieuwend is en mogelijkheden biedt tot eem gedifferentieerde klantbenadering. De operationalisering gebeurt op cen dusdanige wijze dat deze voor wetenschappelijke doeleinden en praktische toepassingen bruikbaar is.

Vervolgens zal in de hoofdstukken 5 en 6 verslag worden gedaan van het empirisch onderzoek. De opzet en uitvoering wan dit onderzoek passeren in hoofidstuk 5 de revue. De resultaten vam dat onderzoek worden in hoofdstuk 6 gepresenteerd.

In hoofdstuk 7 zullen de resultaten geinterpreteerd worden. Eerst worden de resultatern teruggekoppeld aan de onderzoekswragen en worden conclusies getrokken. De met de conclusies verbonden implicaties komen eweneens aan bod, gevolgd door suggesties voor nadepr onderzoek.

Figuur 1.2 geeft de opbouw van het proefschrift schematisch weer. 


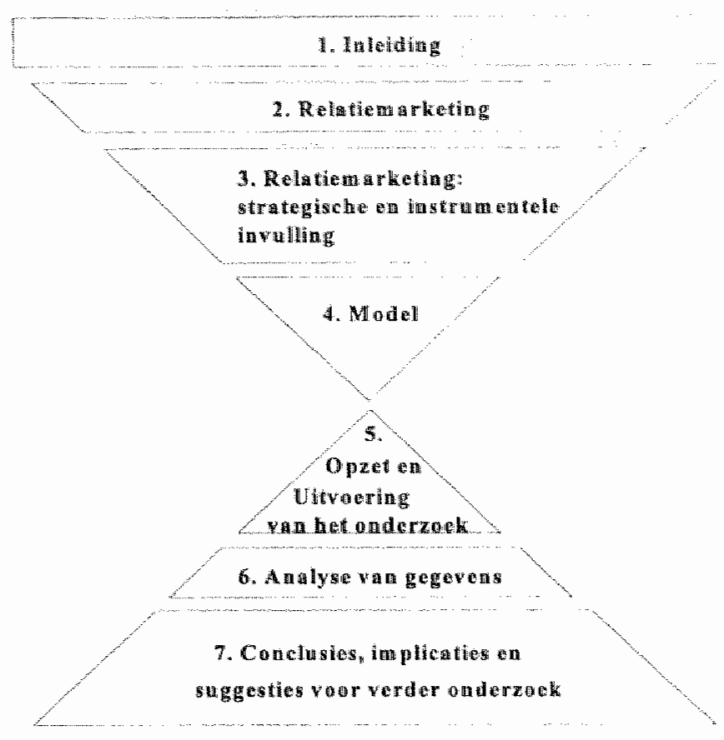

Figuur 1.2 Schematische weergave van de opbouw van dit proefschrin

\subsection{CONCLUSIE}

Organisaties zijn meer en meer genoodzaakt gebruik te maken varu de technologische mogelijkheden teneinde in te spelen op de verdergaande individualiseringstendens en marktfragmentatie. De uit deze tendensen voortvloeiende en alsmaar toenemende vraag naar meer en naar meer verschillende produkten enerzijds en de vraag naar persoonlijke behandeling en communicatie anderzijds zal zijn weerslag hebben op de te voeren marketing(communicatie)strategie van een onderneming. Daarbij zal de andacht van de marketingmanager niet langer alleen gericht kunnen zijn op het werwen van nieuwe klanten, maar zal daarnaast ook gericht moeten zijn op het behouden van bestaande klanten: "Marketing's 'Dating Game' has evolved into a continuing 'Love Connection" "zoals het motto van dit hoofdstuk luidt.

Het behouden van klanten impliceert het managen van relaties. Relatiemanagennent vereist op zijn beurt "relationship measurement", het meetbaar en bruikbaar maken van het relatieconcept. Teneinde de effecten van relatieversterkende matregelen te kunnen evalueren, is het nodig de sterkte van relaties (de mate van binding) tussen consumenten en organisaties te kunnen meten en verklaren. Dit proefschrift richt zich op het ontwikkelen van een instrument om enerzijds relatiesterkte te meten en anderzijds aanbevelingen te doen voor het gebruik van dat instrument ten behoeve van managementdoeleinden. 


\section{HOOFDSTUK 2: RELATIEMARKETING}

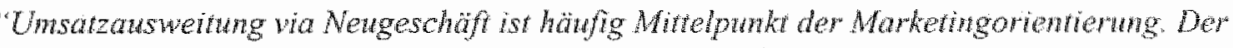
Kundenbindung den gleichen Stellenwert zuzwweisen. erfordert einscheidende Korrektw. ren der Marketingstrategie. "s

Bunk (1992, p. 44)

\subsection{INLEIDING}

Voordat nader ingegaan word op de verschuving wan transactiemakeding nat meer op het individu gerichte relatiemarketing, zal eerst andach worden besteed adu wat onde* transacties en ransactienaketing verstaan wordt $(\$ 2.2)$. Vervolgens wordt roegelicht wat relaties en relatiemarketing behelzen (\$2.3). Hier zal bliken da velatiemarketmg past bimen en voonboum op het strategische makkting concept. Fandad dat relatienaweting hier als een concept gepositioneerd wordt. Aanshitend zullen relaties nader geanalyseerd" worden door deze vanuit twee verschillende invalshoekent te belichten. De eerste invalshoek onderscheidt een prestatiedimensie en een persoonsdimensie binnen een relatie. De meede invalshoek benadent relaties wantit een gedragsdimensie en een belevingsdimensie (52.4). De geroewde verschwing van transactiewarketing naar relariemarketing kan aan de hand van een relatiecontimüm nader geilhstreerd worden (\$2.5). Dit relatiecontimuim kan tenens aangewend worden om aan te geven dat ook een individuele relatie veelat begint met een enkevoudige transactie on verolgens via herhalingsaankopen mogelijkerwijs tor een op binding gebaseerde relatie wit te groeien. Met ander woorden een relatie ken een levenscychs waarin de relatiesterkte varieert $(\$ 2.6)$.

\subsection{TRANSACTIES EN TRANSACTIEMARKETUNG}

Marketing is van oudsher gericht op het bewerksteligen van transacties met anonieme (elementen uit) doelgroepen: "(..) there has been a long-standing and clear tendency for marketing practice and theory to focus on the sale, the single event of a transaction, as the objective of marketing activity and the dependent variable for analysis. This emphasis on single transactions fits well with the profitmaximization paradigm and the related analyical techniques of optimization" (Webster, 1992, p. 6). Bij een transactie vind cen ruil plats, meestal van goederen or diensten tegen geld. Een pure transactic is een eenmalige uitwisseling van waarden tussen twee partien, zonder voorafgaande of opvolgende interactie. De prijs, die in een competitieve markt tot stand is gekomen, bevat woor beide partijen alle noodzakelijke informatie on de uitwisseling tot stand te brengen. Een eenmalige arakoop wan merkloze benzine bij een onafhankelijk tankstation in een vreende ongeving, waarvoor contant betald wordt, benadent een discrete transactie. Pure transacties komen in werkeligheid echler maar zelden woor en ziju in dat opzicht abstract. Zij markeren echter het begin warn cen continuim voor relaties en allianties en zorgen voor een bruikbaar startpunt voor theorstische analyso 
(Hakansson, 1982; Dwyer et al., 1987; Webster, 1992). Een discrete transactie vormt aldus het fundament warop een relatie gebouwd kan worden.

Transacties worden door allerlei soorten organisaties aangegaan. Dergelijke organisaties kunnen marketing toepassen. Indien de marketing activiteiten zich daarbij concentreren op de ad hoc transactie en de daanut woortwloeiende ruil van een goed of dienst tegen geld, met in het algemeen anoneme klanten, dan is sprake van ransactiemaketing (zic ook Kotler, 1988). Deze "new customer only" marketingbenadering (Berry, 1983, p. 25) is een korte termijn orientatie, geschikt indien zowel afnemer als aanbieder een korte termijn visie hebben en primair op de nuil gericht zin (Peelen et al., 1987). Als maatstaven van succes van de ondeneming hanteren zij daarbij huidige omzet en winst op de transaciles. Het dominante koopcriterium is de huidige waarde van het verkregene. Samenvattend worden transactienarketing de volgende kenmerken toegedicht (Christopher et al., 1991):

- nadruk op eenmalige verkoop;

- oriẻntatic op produkt kenmerken;

- korte termijn denken;

- weinig aandacht voor klantenservice;

- beperkte klantenbinding;

- matig contact met klanter; en,

- kwaliteit is primair een zorg van produktie.

Transactiemarketing is de meest traditionele en elementalre worm van marketing en wordt daarom ook wel als traditionele, klassieke of massa-marketing aangeduid. Daarin wordt de verkoop gezien als het eindresultaat van het marketingproces en is er geen betekenisvolle, voortdurende relatie tussen organisatie en klant (Webster, 1992). Er is als het ware sprake van "exchanges as discrete events" (Dwyer et al., 1987, p. 11), "... being conducted on an ad hoc basis" (Arndt, 1979, p. 70). Dit "n tegenstelling tot relatienarketing, waar in de volgende paragraf nader op wordt ingegaan.

\subsection{RELATIES EN RELATIEMARKETING}

\subsubsection{RELATIES}

"If we limit our attention to the study of single, isolated exchanges we ignore much of the heart of what we call "marketing". Good marketing management emphasizes the building of longterm relationships" (Houston en Gassenheimer, 1987, p. 10). Daarbij komt dat veel transacties in feite plaatsvinden in de context van voortdurende relaties tussen organisaties en klanten (Webster, 1992). Het geven van een sluitende definitie van relaties zou hier gewenst zijn. Echter, relaties komen in verscheidene en complexe vormen voor. Enerzijds wordt het begrip relatie dan ook nauwelijks gedefinieerd in de relatiemarketing literatuur (Strandvik en Liljander, 19946). Anderzijds, daar waar dat wel gebeunt, maakt dat het definiëren van het begrip relatic onvermijdelijk arbitrair (Hinde, 1979) en is er geen sprake van een unieke en algemeen geaccepteerde definitie van het begrip relatie (Poiesz en Van Raaij, 1993). Door de gecompliceerdheid van een relatie lijkt het derhalve aangewezen on eerst naar de kenmerken van relaties te kijken en vervolgens te definiëren wat een relatie is. Het betreft de volgende eigenschappen van een relatie (Diller en Kusterer, 1988; Poiesz en Van Raaij, 1993):

a) er is een bepaalde mate van interactie tussen tenminste twee partijen,

b) die gedurende langere tijd plaatsvindt, en die 
c) gekarakteriseerd word door een bepaalde mate wan continuiteit in die zin dat interacties uit het verleden de huidige interacties beinvloeden en de huidige interacties de toekomstige interacties beinyloeden;

d) de effecten van de interactie hangen af van feitelijke gebeurtenissen en van de subjectieve beoordeling van gebeurtenissen;

e) bij het beschrijwen wan de aard van een relatie kan een onderscheid worden gemaakt tussen de formele aspecten en de informele aspecten van de interactie!

Hoewel Diller en Kusterer (1988) en Poiesz an van Raaij (1993) expliciet aangeven dat het eigenschappen betreft van relaties tussen organisaties, noemen Peelen (1989b) en Diller (1994) overeenkomstige kenmerken bij relaties tussen orgamisaties en consumenten. Bovenstaande kenmerken kunmen dan ook als algemene kemmerken wan een relatie beschouwd worden. Gelet op de context van ons onderzoek zal de definitie van een relatie, zoals deze door Diller (1994) wordt aangereikt, als uitgangspunt genomen worden. Een commerciêle relatie tussen een aanbieder en een consument laat zich dan als volgt definièrem:

Een relatie is een door economische en nief-economische doelstellingen (1) geleid, direct (2), integretend (3) en op meerdere transacties betrekking hebbend (4) interactieproces (5) tussen een aanbieder en een consument (6) in verband met de aanschaf en het ge-/verbruik van huishoudelijke goederen en diensten (7).

Deze zeven elementen zullen wij nu kort toelichten";

(1): Aan Business-to-Business (B-to-B) relaties liggen in het algemeen voomamelijk economische of rationele overwegingen ten grondslag. Ook in een relatie tussen een aanbiedende organisatie en een consument wordt de aanbieder voonamelijk door economische of rationele motieven geprikkeld deze relatie te continueren. Vanuit de consument gezien kunnen de redenen voor de relatie daarentegen veelal in twee categorieën worden ondergebracht: emotionele (niet-economische) gronden en rationele (economische) gronden. Sheth en Parvatiyar (1995) geven aan dat consumenten relaties aangaan als gevolg van persoonlijke invloeden, sociale invloeden en institutionele invloeden. Met name de sociale en institutionele factoren zijn weelal niet-economisch van aard.

(2): Noodzakelijk voor een relatie is de mogelijkheid tot direct, interactief contaci, hetzij persoonlijk ("face-to-face") hetzij via directe media als brief, telefoon of interacheve electronische media. Alleen door een dergelijk direct contact kan zïch, met name vanuit het perspectief van de consument, een individuele relatie ontwikkelen.

(3) en (4): Herin komt de voor relaties belangrijke eigenschap tot uitdrukking dat interacties uit het verleden de huidige interacties beinvloeden en de huidige interacties de toekomstige interacties beïnloeden. In de relatie ontstat arvaring met de alhandeling van de transactic,

\footnotetext{
'Formele aspecten wan de interactie hebben betrekking op de meer objectieve economische, financièle en juridische beperkingen die de aard en de dutur van de relatic in bepaalde mate, en in sommige gevallen zelfs volledig, kunnen bepalen. De informele aspecten betreffen subjectieve, psychologische elementen, zoals wederzijdse verwachtingen, affectic of watardering, vertrouwen en commiment (Poiesz en Van Ravij, 1993).

${ }^{2}$ Daarbij baseren wij ons op: Dwyer et al. (1987); Diller en Kusterer (1988); Peelen (1989a; 1989b); Peelen et al. (1989); Poiesz en Van Raaij (1993); Bruhn en Bunge (1994); Diller (1994).
} 
ervaring die de verwachtingen voor toekomstige interacties belnwloedt. Transacties maken aldus een integrerend bestanddeel wit van cen relatie.

(5): De definiering als interactieproces maakt duidelijk dat een relatie een dynamisch proces is en geen statische toestand. Een relatie ontwikkelt zich en kan meerdere fasen doorlopen.

(6) en (7): De beperking tot relaties tussen een aanbieder en een consument in verband met de aanschaf en het ge/verbruik van huishoudelike goederen en diensten voeit voont uit de in deze studie gekozen optick on heef uitsluitend tot doel andersoortige relaties, waaronder ook privé-relaties, buiten de definitie te houden.

\subsubsection{RELATHEMARKETING}

Relaties kunnen worden opgebouwd met voor de organisatie belangrijke belangengroepen, zowel binnen als buiten de organisatie. Daarbij walt te denken aan (Morgan en Hunt, 1994; Christopher et al., 1991; Grönroos, 1990b; zie figuur 2.1):

'Supplier partwerships':

1 relaties tussen fabrikanten en hun leveranciers van goederen en onderdelen, resulterend in bijvoorbeeld 'Just-In-Time'-levering en 'Total Quality Management';

2 relaties tussen een bedrijf en haar dienstverlenende organisaties, waaronder reclame- en marktonderzoekbureaus, financiële diensverleners en verzekeringsmaatschappijen;

'Lateral partmerships'?"

3 strategische allianties tussen bedrijven en hun concurrenten, bijwoorbeeld waar het technologische ontwikkelingen betreft;

4 allianties tussen een bedrijf en non profit organisaties, waaronder milieubewegingen;

5 partnerships voor gezamenlijke onderzoeks- en ontwikkelingsprojecten, zoals tussen bedrijven en locale, regionale, provinciale of (inter)nationale overheden;

'Buyer partnerships:

6 lange termijn relaties tussen bedrijven en eindafnemers;

7 werkrelaties, zoals deze voorkomen tussen een bedrijf en haar tussenpersonen in het distributiekanaal;

'Tnernal partnerships":

8 relaties tussen functionele afdelingen binnen een organisatie;

9 relaties tussen een bedrijf en haar werknemers, het aandachtsveld van Human Resource Management (HRM) en interne marketing;

10 relaties binnen een organisatie tussen afzonderlijke eenheden, zoals dochterondernemingen, divisies en strategische bedrijfseenheden.

Teneinde al deze relatievomen in hun detinitie te betrekken onschrijwen Morgan en Funt (1994, p. 22) relatienarketing als volgt: "Relationship marketing refers to all marketing activities directed toward establishing, developing, and maintaining successful relational exchanges".

In ons onderzoek richten wij ons, zoals in hoofdstuk 1 aangegeven, op de zogenaamde 'buyer partmerships", in het bijzonder "lange termijn relaties tussen bedrijven en eindafnemers" (relatievorm 6, zie figuur 2.1). 


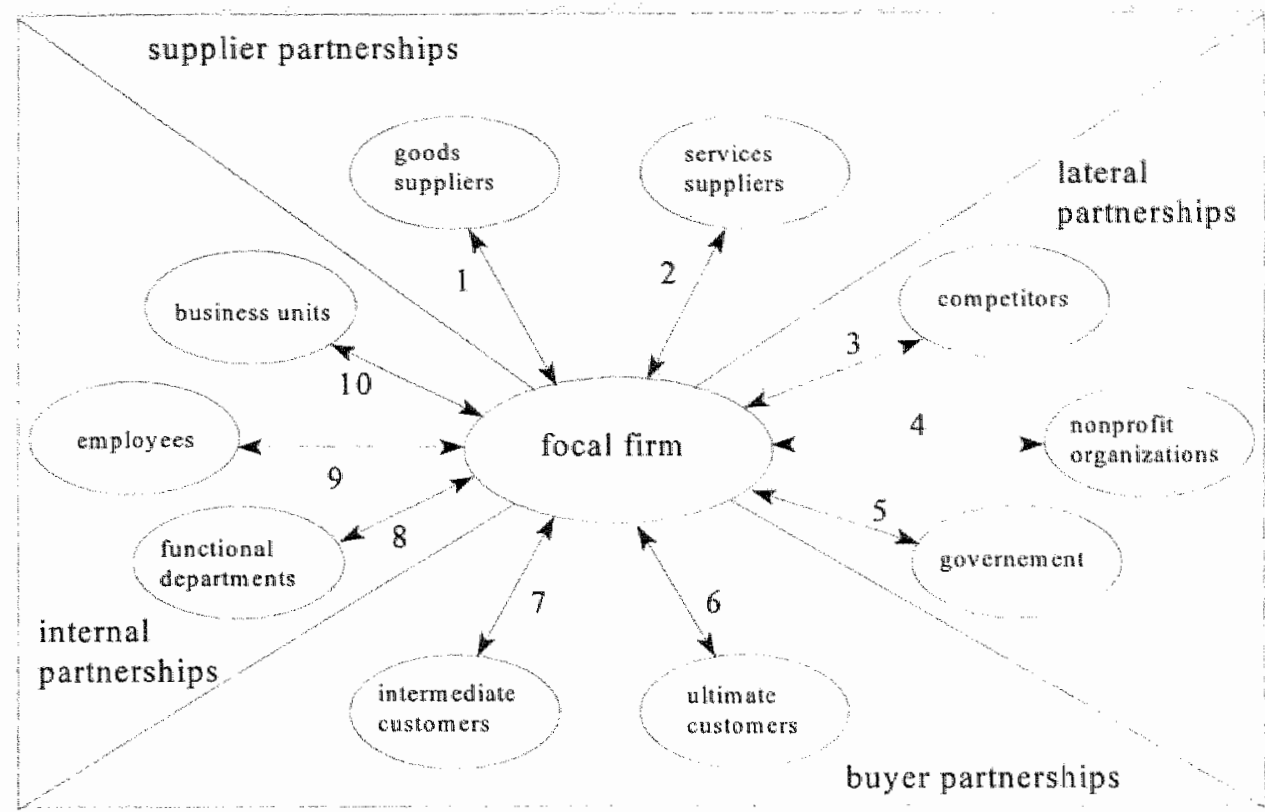

Figuur 2.1 Tien relatievormen

Bron: Morgan en Hunt (1994, p. 21)

Relatiemarketing houdt dan in het streven naar duurzame, individuele betrekkingen tussen aanbieder en afnemer, gericht op het bevredigen van wederzijdse wensen en behoeften (Peelen et al., 1987; Hoekstra en Raaijnaakers, 1992). Dit streven past bimen het strategische marketingconcept zoals geformuleerd door Day en Wensley (1983, p. 83): "... the marketing function initiates, negotiates, and manages acceptable exchange relationships with key interest groups, or constituencies, in the pursuit of sustainable competitive advantages, within specific markets, on the basis of long run consumer and channel franchises". Uit dit strategische marketingconcept blijkt dat het woor het bewerkstelligen van een verdedigbaar concurrentievoordeel van belang is, relaties tot stand te brengen en te onderhoudten met woor de organisatie belangrijke belangengroepen, zowel binnen als buiten de organisatie, wataronder afnemers (Leeflang, 1986). Overeenkomstig Bruhn en Bunge (1994) kan geconcludeerd worden dat relatiemarketing primair een consequente, vendere ontwikkeling van thet marketingconcept is. Vanuit dat gezichtspunt waargenomen is relaticmarketing geen nieuwe fase in de ontwikkeling van managementfilosofieen (na de op het produkt georienteerde filosofie, de op de verkoop georiënteerde filosofie en de marketing conceptie) en kan niet als 
een nieuw makketingparadigma gezien worden. Relatiemarketing is eerder te beschouwen als een fase in de ontwkkling van de marketing conceptie zelf. Daarbij vindt opnieuw een verbreding en verdicping van deze conceptie plaats.

Binnen relatiemarketing gaal het, in tegenstelling tot transactiemarketing, niet primair om de winst op de transacties, maat on de winst op de relaties. Dat kan alleen bij ruil met bestaande klanten. In sommige gevallen kan dat betekenen dat individuele transacties zelfs verliesgevend zijn. Doel is echter een winstgevende relasie op te bouwen (Grönroos, 1994a). De relatie staat primair, de ruil is hiervan een uitvloeisel en dus secundair. Via tevredenheid wordt gepoogd de toekomstige omzet en winst en darmee de continufteit van de onderneming veilig te stellen. Als maatstaf voor succes geldt de lange termijn waarde van de klant, ook wel Customer Life Time Value (CLTV) genoend.

Samenvattend worden aan relatienarketing de volgende kenmerken toegeschreven (Christopher at al, 1991):

- nadruk op behouden van klanten;

- orientatie op produkt 'benefits';

- lange termijn denken;

- veel alandacht voor klantenservice;

- grote klantenbinding;

- veel contact met klanten; en,

- kwaliteil is een zorg van iedereen.

Relatiemarketing beoogt het aantal herhalingsaankopen te stimuleren en de klantenbinding en merktrouw te vergroten: "... a goal to which advertising has always aspired. Relationship marketing does not change that goal - it only provides a surer path for realizing it" (Copulsky en Wolf, 1990 , p. 20 ).

Dit onderzoek concentreert zich op de witeindelijke consument als relatiepartner. In dat kader wordt relatiemarketing overeenkomstig Shani en Chalasani (1992, p. 44) gedefiniëerd als:

"an integrated effort to identify, maintain, and build up a network with individual consumers and to continuously strengthen the network for the mutual benefit of both sides, through interactive, individualized and value-added contacts over a long period of time".

3 Ook Willenborg en Leeflang (1997). Petrof (1997) en Gelderman en Tuninga (1998) ontkennen dat er sprake is van een paradigmawisseling in marketing. Op basis van de onderling sterke overeenkonsten tussen transacticmarketing en relatiemarketing zijn Willenborg en Leeflang (1997) van mening dat transactiemarketing en relatiemarketing beter op te vatten zijn als alternatieven woor verschillende marktsituaties. In beide benaderingen is sprake van wederzijdse afhankelijkheid tussen partijen, cooperatief gedrag, het nastreven van het gemeenschappelijk belang en cen 'win-win' verdeling van uitkomsten. Bij transactiemarketing wordt echter een korte-temijn orientatie gehanteerd die zich uitstrekt tot en met de consumpticfase en consumententevredenheid, terwijl bij relatiemarketing een lange-termijn oriëntatie gehanteerd wodt die zich over meerdere transacties uitstrekt. Petrof (1997) en Gelderman en Tuninga (1998) zijn van mening dat op imboudelijke gronden geen sprake is van een nieuw marketingparadigma: het wasthouden en tevredenstellen van afnemers heef altijd aan de basis van het marketingdenken gelegen en het zou weinig. zinvol zijn om binnen het vakgebied marketing relaties le bestuderen die niet zijn alangegaan met het oog op (potentięle) transacties. 
'Over a long period of time' houdt, gelet op onze definitie van een relatie, in dat de contacten op meerdere, achtereenvolgende transacties betrekking hebben en dat de relatie vanuit die optiek duurzam is.

Nu de begrippen relatie en relatiemarketing zijn gedefuneerd zal exn relatie nader geanalyseerd worden teneinde een beter inzicht te krijgen in de componenten van een relatie en dammee in de mogelijkheden de sterkte van een relatie te meten.

\subsection{RELATIES NADER GEANALYSEERD}

\subsubsection{INLEIDING}

Relaties zijn wanuit twee invalshoeken te typeren. Elke invalshoek kent weet twee dimensies. De eerste invalshoek let op de aard van de ruil en maakt daarbij een onderscheid tussen wat genoemd zal worden de prestatiedimensie en de persoonsdimensie. In de prestatiedimensie staat de economische nil (de transactie) centraal, terwijl in de persoonsdimensie de sociale ruit (de communicatie) centraal staat. De tweede invalshoek benadert relaties vanuit een gedragsdimensie en een belevingsdimensie. Darin staan de feitelijke gebeurtenissen respectievelijk de subjectieve beoordeling van de gebeurtenissen centraal.

Hoewel beide invalshoeken theoretisch te onderscheiden zijn, staan ze in de praktijk niet los van elkaar en komen veelal gezamenlijk voor. Zo vind in een relatic commumicatie plaats tussen personen (persoonsdimensie) over de zakelijke aspecten van de transactio (prestatiedimensie) hetgeen kan uitmonden in daadwerkelijke ruil (gedragsdimensie) en het ontstaan van bijvoorbeeld vertrouwen (belevingsdimensie) in de handelspartner (Diller, 1994). Echter om analytische redenen worden de twee invalshoeken met hun dimensies hier separat behandeld, teneinde een beter inzicht te krijgen in de componenten van een relatie.

\subsubsection{DE PRESTATIEDIMENSIE EN DE PERSOONSDIMENSIE}

Het onderscheid tussen economische en sociale ruil is terug te vinden bij bijvoorbeeld Gummesson (1987a). Hij onderscheidt twee typen relaties die de door de klant waargenomen kwaliteit beïnvloeden. Ten eerste de professionele relaties, waar de contactpersoon verstand van zaken heeft. Ten tweede de sociale relatices die essentice zijn in combinatie met de professionele relaties en mede bepald worden door de communicatieve vaardigheden van de handelspartmer. Sociale relaties refereren ook aan de mogelijkheid tot en persoonlijke vriendschap te komen. In datzelfde verband spreken Tumbull en Wilson (1989) over structurele binding, respectievelijk sociale binding. Peelen (1989b) geeft aan dat binnen een relatie enerzijds ruiltransacties plaatswinden (in hel algemeen uitwisselingen van goederen en/of diensten tegen geld) en anderzijds tweezijdige communicatie tussen de betrokken partijen plaatsvindt, die verband houdt met de ruiltransactie. Wilson (1990) en Czepiel (1990) gebnuken in overeenkomstige betekenis de temen economische en persoonlijke (of sociale) ruil. Wilson (1990, p. 1) concludeen dat "The fundamental basis of a relationship is an economic exchange relationship in which each party believes that they have received fair value in the exchange. Another important element is the personal exchange that results as a byproduct of the economic exchange. If the personal exchange and the economic exchange are satisfactory, then the basis for an enduring relationship exists". Een professionele zakenrelatie omschrijft Wilson als een relatie waarbij de economische tevredenheid groot is en de sociale 
tevredenheid aan een minimum voldoet. Sociale banden zijn volgens hem "the glue that holds individuals together". Steenkamp (1991) baseert zich op Wilson en onderscheidt ten aanzien van de geleverde prestatie twee soortgelijke dimensies: de economische prestare en de persoonlike prestatie. Daarbij zinn. volgens Steenkamp kwaliteil (inclusief de service) en de verhouding tussen prijs en geleverde kwalliteit (value") de twee aspecten van de economische prestatie, terwijl de persoonlijke prestatie bepaald wordi door de mate waarin de managers in kwestie uit de contacten persoonlijke bevrediging halen. De relatie kan dan variëren tussen strikt zakelijk (economische prestatie) en goede persoonlijke vrienden (persoonlijke prestatie). Stom (1991) maakt een onderscheid tussen de object-subject relatie op basis van de $4 \mathbb{P}^{9} \mathrm{~s}$ (produkt, promotie, plaats on prijs) en de subject-subject relatie op basis van de 3 R's (reputatic, relatie, ruiliransactie). Diller (1994) tenslotte, brengt het onderscheid tussen prestatiedimensie en persoonsdimensie tot uitdrukking met de termen 'Sachebene" en 'Kommunikationsebene'.

Samenvattend geef tabel 2.1 een oxerzicht wan de auteurs en de door hen gehanteerde begrippen. Daaruit blijkt op welke wijze in verschillende studies een prestatiedimensie en een persoonsdimensie onderscheiden worden bimen relaties.

Tabel 2.1 Overzicht van auteurs die zowel exn prestatiedimensie als een persoonsdinensie binnen een relatio onderkennen

\begin{tabular}{|c|c|c|}
\hline Aweur & Prestatiedinensie & Persoonsidimensie \\
\hline Gummesson (1987a) & professionele relatie & sociale relatie \\
\hline Tumbull en Wilson (1989) & structure le binding & sociale binding \\
\hline Peelen (1989b) & $\begin{array}{l}\text { aankopen } \\
\text { rulltransactie } \\
\text { "exchange" }\end{array}$ & $\begin{array}{l}\text { communicatic } \\
\text { informatie }\end{array}$ \\
\hline Wilson (1990) & $\begin{array}{l}\text { professionele binding } \\
\text { "economic exchange" }\end{array}$ & $\begin{array}{l}\text { sociale binding } \\
\text { 'personal exchange" }\end{array}$ \\
\hline Czepiel $(1.990)$ & "economic exchange" & 'social exchange" \\
\hline Steenkamp (1991) & economische prestatie & persoonlijke prestatie \\
\hline Storm (1991) & objectosubject relatice & subject-subject relatie \\
\hline Diller $(1994)$ & "Sáchebene" & 'Kommunikationsebene' \\
\hline
\end{tabular}

\subsubsection{DE GEDRAGSDIMENSIE EN DE BELEVINGSDIMENSIE}

Relaties bevatten een gedragsdimensie: "A relationship implies first some sort of intermittent interaction between two (or more) people, involving interchanges over an extended period of lime" (Hinde, 1979, p. 14). Daanatst beïnloedt iedere participant de andere: iedere handeling is (deels) een reactie op het gedrag van de ander in het verleden en wormt mogelijk een stimulus voor zijn toekomstig gedrag. Een relatic is daamee totaal icts anders dan cen pure transactie: een relatie bestaat uit een aaneenschakeling van interacties in de tijd. Herhalingsaankopen en de daarmee gepaard gaande uitwisselingen van geld, goederen, informatie en diensten duiden op het ontstaanbestaan van een relatie (Webster, 1992). Ook. Strandvik en Liljander (1994b) stellen dat, in geval van een discrete dienst (zoals bijvoorbeeld cen verblij in een hotel of een restaurantbezoek), er een relatie ontstaal wanneer de tweede 
aankoop plaatsvindt. Daarbij merken zij op dat "It is, however, not sufficient to focus on only repurchase events as this gives a very simple picture of relationships. In this case consideration is meither given to whether the customer has a choice or not, nor to the customer's commiment towards the service firm". Met andere woorden: het tot tweemaal toe kopen van een produkt is slechts een minimum vereiste om van een relatie te kunnen spreken (Diller, 1994; Strandvik en Liljander, 1994b; Bames, 1995). Het wordt als belangrijker aangenerkt dat de interaches in de tijd aaneengeschakeld zijn: de huidige interacties worden beinvloed door die in het verteden èn beinvloeden die in de toekomst (Hinde, 1979; Dwyer et al, 1987; Peelen, 19896; Poiesz an Van Raaij, 1993; Diller, 1994).

Dit impliceert dat een consument de voorgaande interacties beleeft en verwerkt hetgeen bepalend is voor toekomstige interacties (Peelen, 1991). Naast een gedragsdimensie kan in relaties dus ook een belevingsdimensie onderscheiden worden. De gedragsdimensie komt bij Peelen (1989b) en Peelen et al. (1989) tot uitdrukking in de termen 'gedrag' en "interactie", terwill zij voor de belevingsdimensie de termen 'binding", "beleving' en 'attitude' gebruiken. De begrippen "behavior" en "shared experiences" van Czepiel (1990) brengen eveneens het onderscheid tussen gedrag en beleving tot uitdrukking. Het onderscheid dat Wilson (1990) maakt tussen economische en socialle ruil enerzijds en economische en sociale tevredenheid anderzijds geeft aan dat ook hij een gedragsdimensie en een belevingsdimensie onderkent.

Storm (1992) onderscheidt met betrekking tot relaties een zichtbare bovenbouw en een an het oog onttrokken onderbouw. De bovenbouw omvat de zichtbaar verlopende zakelijke interacties, de uitwisseling van waarden op verschillende tijdstippen en betreft dus de interacties tussen personen, de op elkaar gerichte activiteiten. De onderbouw betreft het aan de interacties ten grondslag liggende geheel van gedachten, gevoelens, zingevingen en strevingen. Beide moeten positief geladen zijn om van een effectieve samenwerkingsrelatie te kumnen spreken: de zakelijke bovenstroom dient door een emotionele onderstroom te worden ondersteund.

Uit de eerder vermelde eigenschappen van een relatie blijkt dat ook Poiesz en Van Raaij (1993) het onderscheid tussen een gedragsdimensie en een belevingsdimensie maken: de effecten van de interactie hangen af van feitelijke gebeurtenissen en van de subjectieve beoordeling van gebeurtenissen. Verder stellen zij dat bij het beschrijwen van de aard van een relatie een onderscheid kan worden gemakt tussen de formele aspecten en de informele aspecten van de interactie: "Elaborating on this last characteristic, the objective, fomal aspect includes economic, financial, and judicial constraints which dictate to some extent, or in some cases even to the full extent, the nature and the duration of the relationship. The informal aspect includes subjective, psychological elements such as mulual expectations, affect or appreciation, trust and commitment" (p. 5). Zij gaan er dus eveneens van uit dat een relatie voor een deel economisch en utilitair is en woor een deel psychologisch.

Diller (1994) tenslatte maakt in dit verband een onderscheid tussen rationeel gedrag en emotionele houding.

Samenvattend geeft tabel 2.2 een overzicht van de auteurs en de door hen gehanteerde begrippen gerangschikt naar een gedragsdimensie en een belevingsdimensie van cen relalie. 


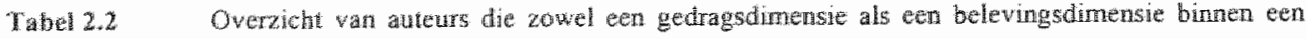
relathe onderkenten

\begin{tabular}{|c|c|c|}
\hline Awten & Gedrags distenste & Beleningstimensie \\
\hline $\begin{array}{l}\text { Peten }(19896) \\
\text { peter et a }(1989)\end{array}$ & $\begin{array}{l}\text { interactics } \\
\text { gedrag }\end{array}$ & $\begin{array}{l}\text { binding } \\
\text { beleving } \\
\text { athitude }\end{array}$ \\
\hline Czepiell (1990) & 'Gehavior' & "shared experiences" \\
\hline Wison $(1900)$ & $\begin{array}{l}\text { "economic exchanges" } \\
\text { = business outcomes) } \\
\text { "personal exchange" } \\
\text { (= personal outcomes) }\end{array}$ & $\begin{array}{l}\text { "economic satisfaction" } \\
\text { "social personal satusfaction" }\end{array}$ \\
\hline Storm (1992) & bowerbouw & onderbouw \\
\hline Proverz \& Van Raraj (1993) & $\begin{array}{l}\text { "actual events" } \\
\text { whilitatir }\end{array}$ & $\begin{array}{l}\text { "subjective appraisal of events" } \\
\text { psychologisch }\end{array}$ \\
\hline Diller $(1994)$ & "Rationales Verhalten" & "Emotionales Verthalten" \\
\hline
\end{tabular}

\subsubsection{RELATIETYPERINGEN}

De wee bowengenownde invalshoeken kunnen worden gebruikt om verschillende typen van relaties te onderscheiden. Gelet op het onderscheid tussen prestatiedimensie en persoonsdimensie kunnen de volgende relatietypen worden onderscheiden. Betreffen de interacties in hoofdzaak economische ruiltransacties, dan betreft het een professionele relatie of economische ruilrelatie (Gummesson, 1987a; Czepiel, 1990; Wilson, 1990). Storm (1991) spreekt in dit verband van een object-subject relatie. Indien de interacties daarnaast ook persoonlijke uitwisselingen omvatten, dan is er sprake van sociale relaties (Czepiel, 1990; Wilson, 1990), "... which are essential in combination with the professional relations ..." (Gummesson, 1987a, p. 42). Storm gebrukt hierwoor de aanduiding subject-subject relatie. Tabel 2.3 geeft de werschillende relatietyperingen op basis wan het onderscheid in prestatie- en persoorsdimensie kort weet.

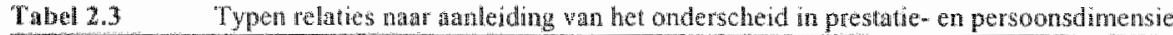

\begin{tabular}{|c|c|c|}
\hline Antem & $\begin{array}{l}\text { Rohates gebasend ap: } \\
\text { prestatsedinemsie }\end{array}$ & $\begin{array}{l}\text { Relaties gebaseard op: } \\
\text { prestatedimensie + persoonsdonense }\end{array}$ \\
\hline Gumnesson $(1987 a)$ & \multirow{2}{*}{ professionele relatie } & \multirow{3}{*}{ socinle relatie } \\
\hline Canpial (1990) & & \\
\hline Wilson (1990) & cononische ruilrelatie & \\
\hline Storm (1991) & object-subject relatie & whibectusubject relatic \\
\hline
\end{tabular}

Gelet op de dimensies gedrag en beleving kumnen de volgende typen relaties onderscheiden worden. Is een relatic met name te beschrijven aan de hand van kenmerken van de gedragsdimensie dan is er sprake van een "spurious relationship": "... a spurious relationship is based upon the mere contimuation of past behavior" (Poiesz en Van Raaij, 1993, p. 5). Schijns en Lemmink (1994) spreken van een transactierelatie: een op transacties gebaseerde relatie. Is 
de relatie daamaast ook sterk gebaseerd op kemmerken van de belevingsdmensie dan is ct sprake van een echte relatie: "A true relationship is based on dedication and nutual commiment" (Poiesz en Van Raaij, 1993, p. 5). Dit relatietype wordi door Selinns en Lemmink (1994) angeduid als een coopperatieve relate: een op binding gebasecrde rebatio. Tabel 2.4 wat de verschillende relatietyperingen op basis van het onderscheid in gedragsdimensie en belevingsdimensie samen.

Tubel 2.4

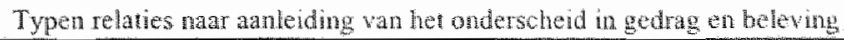

\begin{tabular}{|c|c|c|}
\hline Areur & $\begin{array}{l}\text { Reloties gebaseend op }{ }^{*} \\
\text { gindragsdmensiz }\end{array}$ & 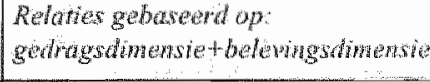 \\
\hline Poiess en Van Ratij (1993) & "spurious relationshipg" & "frae relationslitip' \\
\hline Sching eq Lemmik (1994) & 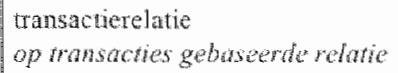 & 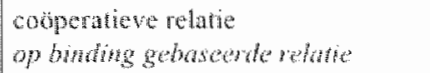 \\
\hline
\end{tabular}

Gelet op de eerdere opmerking dat de twee invalshoeken met hun dimensies naw net elkat verbonden zijn en veelal gezamenlijk voorkomen, alsmede de bevinding van Liljander on Strandvik (1994) dat het in consumentenmarkten relevant is een relatie te omschrijen op basis van de attifude en het gedrag van de consument, zal het onderscheid in gedragsimensie en belewingsdimensie ons primaire untgangspunt zijn bij ons verdere onderzoek nar de sterkte van relaties.

\subsection{HET RELATIE- EN MARKETNGSTRATEGIE CONTINUÜM}

\subsubsection{INLEDDNG}

De in $\$ 1.1$ beschreven verschuiving van een op transacties georienteerce marketingbenadering naar een op relaties georiènteerde marketingbenadering komt tot uitdrukking in een verandering in de aard van de transactie van 'ad hoc' naar' 'ongoing". In de "ad hoc" situatie zijn de marketingactiviteiten gericht op én enkele, geisoleerde transactie met een niet nader bepalde afnemer, zonder weloverwogen pogingen om met die aheme en relatic op to bouwen (Grönoos, 1990b). In de "ongoing" situatie zijn de marketingactiviciten bewust gericht op het opbouwen en onderhouden van relaties, die meer dan een fransactic omwatlon. Bimen die relatie worden transacties gepland en beheerd in plaats van uitgevoerd op ad hoc basis (Andt, 1979). Een relatie is echter geen discrete variabele, maar een continuc warbuble. Relaties kunnen dan ook op een continuüm weergeven worden (Anderson en Narus, 1991a; $1991 \mathrm{~b}$; Grönroos, 1990b; Webster, 1992). Op het relatiecontinuüm kunnen diverse gradaties worden weergegeven, variërend van en enkele, geisoleerde transactic to ecn op binding gebaseerde relatie (zie figum 2.2A): "The existence of a continum ranging from the interaction involved in the purchase of a chocollate bar from a wending machine al a molorway rest shop to the relationship between a paticnt and his on her physicin is obvious. Near the transaction end are exchanges which are discrete, short-tem, and often mechanical; there is little commitment on either side. At the opposite ond is a relationship which is on-going, complex, highly personal and characterized by complete trust and discretion. At some poin along this continum, it may be said that a transaction approach to marketing ceases to be 
appropriate and the possibility for the establishment of a genuine relationship begins"3 (Bames, $1994, \mathrm{pp} .566-567)$

Parallel aan het relatiecontinuam kan het 'marketing strategie continuüm' weergegeven worden (Gronroos, 1990b). Afhankelijk van de (gewenste) positie van de consument op het relatiecontinutum kan door de aanbieder een bij die positie passende marketingstrategie aangeduid worden (zie figur $2.2 \mathrm{~B}$ ).

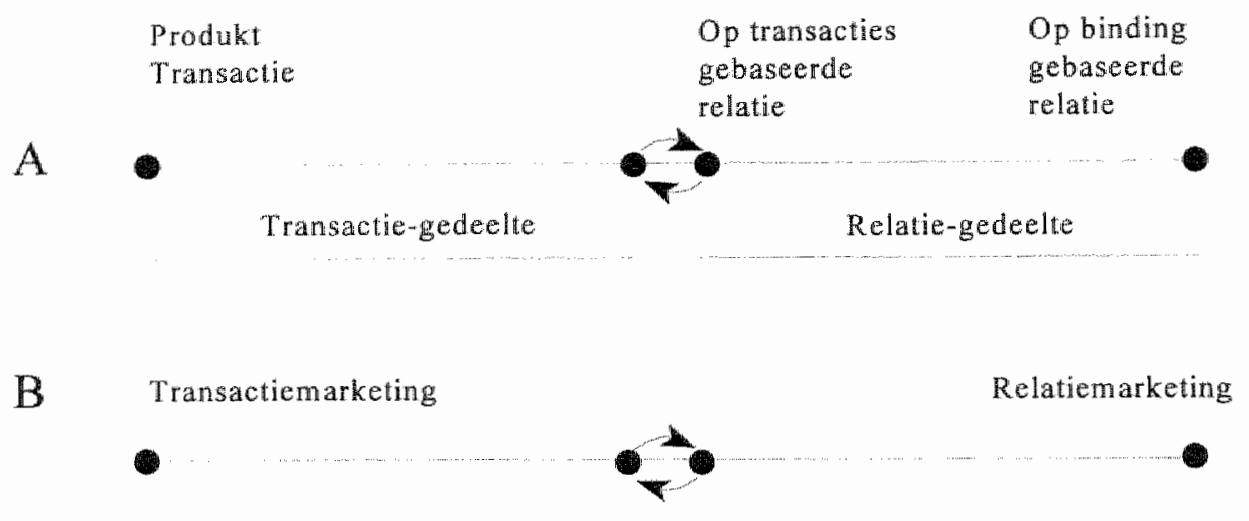

$\begin{array}{ll}\text { Figutur 2.2 } & \text { A. Het relatiecontinuüm } \\ & \text { B. Het marketing strategie continuüim }\end{array}$

Toelichting:

Het relatiecontinuam (A) geft weer de mate waarin interacties variëren van een enkele, ge isoleerde transactie (links) tot een op binding gebaseerde relatie (rechts).

Het marketing strategie continum (B) geef weer de mate waarin een transactiemarketing benadering (links), respectievelijk een relatiemarketing benadering (rechts) de voorkeur geniet, afhankelijk van de (gewenste) positic van de consument op het relatiecontinutum.

De pijlen duiden er op dat ergens langs het relatiecontinutum een transactiemarketing benadering niet langer geschikt lijkt en de nogelikkeid ontstat voor het ontwikkelen wan een relatie (relatiemarketing benadering).

Daur ons onderzok zich richt op het opbouwen en onderhouden van relaties, blijf het linkergedcelte van het relatiecontinuin (daar wat de marketingactiviteiten betrekking hebben op éen enkele, geïsoleerde transactie) hier onbesproken. Tevens beperkt ons onderzoek zich tot de consumentenmarkt. Dit inpliceert dat samenwerkingsmogelijkeden, die veelal binnen industriele markten aangetroffen worden, zoals verticale integratie, buiten beschouwing gelaten worden. 
Derhalve zullen de volgende twee vormen wan een relatie nader besproken worden (zic tabel 2.4): - de op transacties gebaseerde relatie; en,

- de op binding gebaseerde relatie.

\subsubsection{DE OP TRANSACTIES GEBASEERDE RELATIE}

In de op transacties gebaseerde relatie hebben afnemers veelal geen of lage transactiekosten. omschakelingskosten of switchingkosten. Bij een aanbod van een aantrekkelijke combinatie van prijs, produkt, service en/of andere voordelen zullen zij direct daarop ingaan. De afnemer hanteert in zijn relatie tot aanbieders meestal een korte tijdhorizon. Zelfs bedrijven die regelmatig met de afnemer zaken doen, zijn genoodzaakt orn hem bij iedere transactie goede, direct geldende redenen te geven om de relatie woort te zetten. Barlow (1992, p. 35) spreekt in dit verband over 'hard benefits': voordelen die direct een bepaalde geldwaarde vertegenwoordigen, zoals kortingen op produkten of gratis extra"s zoals accessoires (Blijenberg et al., 1996). Herhalingsaankopen kumnen ook werricht worden wil gewoonte of omdat het eenvoudiger en gemakkelijker is om in dezelfde winkel hetzelfde produkt te kopen en aldus de tijd en inspanning, die nodig is on informatie over verschillende koopaltematieven ie verkrijgen en te verwerken, te minimaliseren (Webster, 1992). Poiesz en Van Raaij (1993) spreken in dit verband van 'a spurious relationship': herhalingsaankopen zijn een automatische voortzetting van het gedrag in het verleden en vloeien voort uit beslissingsgemak, inertie of gewoonte. Er is bij de op transacties gebaseerde relatie nauwelijks of geen sprake van binding met de aanbieder als motief voor het verrichten van herhalingsaankopen. Dit in tegenstelling tot de op binding gebaseerde relatie.

\subsubsection{DE OP BINDING GEBASEERDE RELATIE}

In de op binding gebaseerde relatie staat de afnemer voor relatief hoge kosten als hij van aanbieder wil veranderen en hij zal daarom ook alleen als het echt niet anders kan tot een dergelijke verandering overgaan. De overstapkosten kunnen van financiële en/of niet-financięle aard zijn en bestaan uit: inspanning en tijd die het overstappen vergt; geld dat gemoeid is met overstappen; en, het risico dat de nieuwe aanbieder zijn beloften niet nakomt (Jackson, 1985; 1986; Peelen, 1989b). De afnemer hanteert in de relatic een lange tijdhorizon. Bij het kiezen van een aanbieder zal hij dan ook rekening houden met het te verwachten toekomstige vermogen van de verkoper om in zijn behoeften te voorzien en niet uitsluitend afgaan op zijn directe capaciteiten en pluspunten. De aanbieder kan grote invesieringen vooraf rechtvaardigen om niewwe orders van dergelijke klanten te winnen. Voorbcelden in Business to Business $(B-$ to-B) marketing kunnen worden aangetroffen op de gebieden van: communicatie-apparatuur, computers; kantoor-automatiseringssystemen; machines en vliegtuigmotoren. Voor cen zorgvuldig relatiebeheer is het van fundamenteel belang dat de aanbieder begrijpt welke factoren hem binden aan zijn afnemers. Zijn de 'hard benefits' het aas om klanten to lokken, "Research and experience show, however, that it is the soft benefits - the special events, the recognition, the upgrades, the private sales, the advanced information - that really build the rellationship with the customer" (Barlow, 1992, p. 35). De 'hard benefits' zorgen ervoor dat de klant terugkomt, de 'soft benefits' weerhouden de klamt om weg te gaan. Zachte voordelen vertegenwoordigen niet direct een bepaalde geldwaarde, maar meer een emotionele waarde voor de klant (Blijenberg et al., 1996). Poiesz en Van Raaij (1993) spreken in dit verband van 'a me relationship": herhaald aankoopgedrag is gebaseerd op voorkeur voor en binding (commitment) met de aanbieder. 


\subsubsection{AARD DHDING}

De binding kan van financiele, sociale en/or structurele ard zijn (Tumbull en Wilson, 1989; Berry en Parasuraman, 1991; Berry, 1995).

Bij het streven naar een fincheiele binding richt de aanbieder zich primair op het creëren van een band wia frnancicle prikkels, zoals kortingen, om zich te verzekeren van de klatutenloyaliteit. De afnemer moet het recht op het verkrigen van dergelijke financiele voorcelen zoals kortingen echter verwerven. Met andere woorden: de binding is gebaseerd op (uilgestelde) beloning voor verrichte aankopen (Buigholt et al., 1996a). Dit kan op verschillende maneren. Een mogelijkheid is dat de afnemer het recht in de loop van de bjd opbouwt (spaart), bijwoorbeeld op basis van hel aantal transacties of de (gecumuleerde) geldswaarde daarwan. Een andere mogelijkheid is dat de afmemer het recht verwerf door deelname (al of niet tegen betaling) aan en programma. Veel frequent buyerffyer/user programma"s zign hictop gebaseerd. Daar prijs het meest eenvoudig te imiteren marketingmix instrument is, is het potentieel concurrentievoordeel in deze benadering zwak. Bovendien zijn deze zogenaamde prijskopers ook gevoelig voor aanbiedingen van concurrenten en dus snel geneigd wan leverancier te switchen. Wil de leverancier sterke(re) relaties opbouwen dan zal hij] meer moeten doen dan alleen op prijs concurreren.

Een sociale binding kan ontstan indien de relatie gepersonaliseerd wordt, bijvoorbeeld door regelmatig persoonlijk en eventueel op meerdere manieren te communiceren. Daardoor ontstan positieve interpersoonlijke relaties tussen koper en werkoper. Als voorbeeld voor het ontstaan van een sociale band tussen fabrikant en eindafnemer kan genoemd worden de gepersonalisecrde mailings van een luterfabrikant aan zwangere vrouwen en jonge moeders, die een (emotionele) band creüren (Copulsky en. Wolf, 1990). Ondanks dat de aandacht primair is gericht op het creëren van socialle binding kan een agressieve prijsstelling een belangrijk deel uitmaken van de marketing mix. Voorwarde is daamaast ook dat het kemprodukt concurrerend is. Sociale binding is namelijk niet altijd in staat een niet-concurrerend produkt te compensenen. Met andere woorden: indien de kwaliteit van het produkt en/of de prijsstelling niet concurrerend zijn, dan leidt dat tot ontevredenheid bij de afnemer. De sociale band is niet altid in staat de gevolgen van deze ontevredenheid te neutraliseren. Indien het produkt echter net wezenlijk verschilt van dat van de concurrent, zijn sociale bindingselementen vatk doorshggevent voor wat betmen de utuindeljke leverancierskeuze. Ook kan sociale binding crvoor zorgen dat de klant ioleranter is in geval van een tekortkoming van de leverancier. De sociale band vervult als het ware de rol van "satisfier": thet dragt bij aan de reeds aanwezige tevredenheid.

Simturele binding ontstat wanneer de betrokken partijen investeringen doen die niet lefugverkregen kunnen worden indien de relatie beeindigd wordt. Ook is er sprake van structurele binding indien het moeilik is de relatie te beeindigen als gevolg van de complexiteit van en kosten verbonden aan het overstappen naar een andere handelspartner (Tumbull en Wilson, 1989). Structurele binding kan betrekking hebben op economische, organisatorische en juridische banden (Steenkamp, 1991). Hierbij kan in de B-to-B markt gedacht worden aan 'Just-In-Time' (JT) management, specifieke bestel-en voorraadprocedures, gezamenlijk bezit en gebruik van activa of technologieen, technische en/f financiele ondersteuning, of bepaalde dienstwertening, zoals het verzorgen van en specifieke opleiding. In de consumentenmarkt kan gedacht wotden aan mensen die investeren in hard-er/of software teneinde op een 
electronische wije hun (post)bankzaken te kumen afhandelen (ielebankieren of etectronte banking"). Ook het afsluiten van leningen, hypotheken on verekeringen bij finunciole dienstverleners en verzekeringsmaatschappjen leidt tot een vorm van structurele binding. Deze vormen van siructurele binding zijn in hoofdzak gericht op het bieden van een structurele oplossing voor problemen bij de klant. De band hoeft niet absoluut te zijm, maar stork genoeg on de afnemer te weerhouden var leverancier te veranderen. Naamate de structurele binding ZWwakker is, wordt de prijs een steeds sterker concurrentiemiddel. Tenzij er (ook) sprake is wan een vorm van sociale binding. Indien naast structurele binding ook gestreofd wordt natr financièle en sociale binding, dan is het voor de concurrent moeilijk on in deze relatie in te breken.

\subsection{RELATIELEVENSCYCLUS}

Een relatie werd gedefinieerd als een interactieproces. Dit duidt ar op dat een relatie tussen afnemer en aanbieder, en dus ook haar sterkte, zich in de tijd ontwikkelt en verschillende Gasen doorloopt (Diller, 1994). Vandaar dat in deze paragraf kort aandacht word besteed aan de relatielevenscyclus (RLC).

De relatie maakt in de loop van de tijd een ontwikkeling door (Dwyer et al., 1987; Pcelen, $1989 \mathrm{a}_{;}$Bruhn en Bunge, 1994). In de samenwerking tussen de bij de relatie betrokken partijen doorloopt de relatie een aantal achtereenwolgende ontwikkelingsfasen. Dwyor of al. (1987) stellen dat relaties vijf fasen (kumen) doorlopen:

1 awareness of bekendheidsfase. De ene partij onderkent dat de andere partij een geschikto ruilpartner is. Er heeft echter nog geen interactie tussen de partijen platsgewonden. De enige activiteiten die plaatsvinden betreffen de communicatie wan aanbieder naar consument die derhalve nog eenzijdig is;

2 exploration of aftastfase. Hierin bevinden zich klanten die hum eerste aankoop hebben gedara;

3 expansion of groeffase. Hierin doet zich een progressieve toename woon in hat antal transacties;

4 commitment of verzadigingsfase. Het aantal transacties bereikt har maximale hveat, en,

5 dissolution of neergangsfase. Klanten gaan minder interacteren mel de aabicder on de relatie dreigt verbroken te worden of wordt daadwerkelijk verbroken.

Peelen (1989a) rekent de bekendheidsfase niat tot de RLC, gelet op de kemmerken dat een relatie meerdere transacties omwat en de interacties uit het verleden de huidige interacies beinvloeden en de huidige interacties invloed hebben op toekomstige interactes. In de bekendheidsfase heef noch een transactie platsgevonden, noch is er sprake van interactic.

De relatielevenscyclus is rechtstreeks te koppelen aan de loyaliteitsladder (figun 2.3). Deze geeft een aantal identificeerbare fasen weer in de ontwikkeling van een relatie met een klant. Aan de voet van de ladder bevindt zich de prosped, een element wan de doelgroep. 


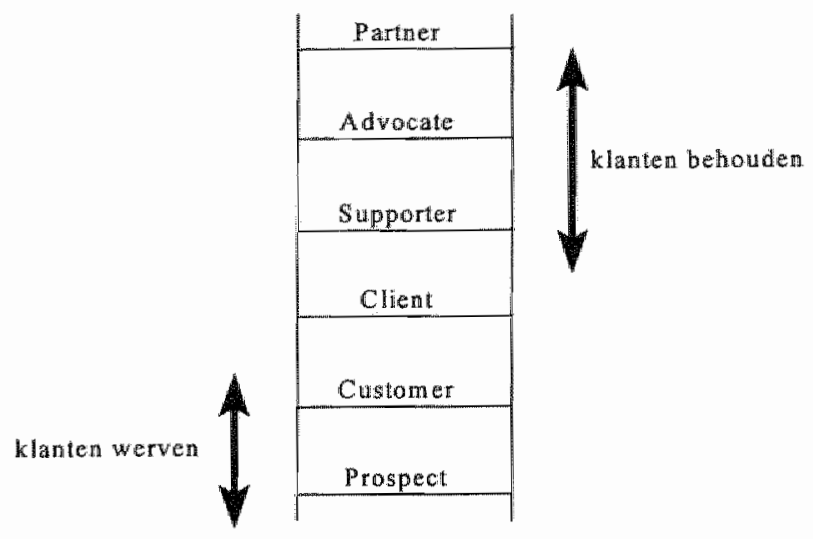

Figuur 2.3 De loyaliteitsladder

Bron: Christopher et al. (1991); Payne et al. (1995)

Traditioneel richt (transactie)marketing zich op het opsporen van deze prospects teneinde deze tot klant (customer) te maken. Met klant wordt dan iemand bedoeld die hetzij éen keer, hetzij zo nu en dan iets koopt. Een cliët daarentegen is bereid herhalingsaankopen te verrichten, hetzij op basis wan gemak, gewoonte of inertie, hetzij op basis van binding.

Het verschil tussen een customer en een cliënt wordt door Donnelly et all. $(1985, \mathrm{p} .113)$ als volgt omschreven:

"Customers may be nameless to the institution; clients cannot be nameless. Customers are served as part of the mass or as part of larger segments; clients are served on an individual basis. Customers are statistics; their needs are reflected on computer printonit summaries. Clients are entities in and of themselves; specifics about them - background data, services used, special requirements - are captured in a data base. Customers are served by anyone who happens to be available; clients are served - at least for nomroutine needs - by the professional ... assigned to them."

Relatiemarketing richt zich op het behouden van deze cliënten en het trachten hen hoger op de loyaliteitsladder te brengen. Overeenkomstig de eerste sporten van de loyaliteitsladder hebben de beginfasen van de RLC betrekking op het werven van klanten: de potentiële klant (prospect) wordt klant (customer). De volgende fasen in de RLC zijn er op gericht de klant voor de organisatie te behouden en tot aanhanger (supporter), vertegenwoordiger (advocate) of zelfs tot partner te ontwikkelen. De latste fase van de $\mathrm{RLC}$, beëindiging van de relatie, kan ieder moment intreden maar dient voorkomen te worden zolang de klant dle orgamisatie meer oplevert dan dat het behouden van deze klant kost. In termen van 'Customer Life Time Value' (CLTV) houdt dat in dat de klant behouden dient te worden zolang de CLTV positief is. Indien dat niet 
meer het geval is, is het zaak dat de organsatie bewust en op gepaste wijze afscheid durfte nemen van de klant en de relatie beëindigt.

Uit de RLC kan afgeleid worden dat de relatiesterkte verondersteld wordt toe to nemen, haar naximum bereikt in de voorlaatste fase en vervolgens afneent. Daarbij dient echter opgemerkt te worden dat de kritiek ten aanzien van de produktlevenscyclus (Dhalla en Yuspeh, 1976), ook hier van toepassing is. Zo kan het verloop van de RLC niet als een gegeven, maar cerder als een resultante van ondemomen activiteiten gezien worden. Kennis van de RLC echter helpt cen organisatie bij het opstellen van haar marketing(communicatie)strategie. De relatielevenscyclus. is wat dat betreft vergelijkbaar met de portfollo-analyse: een instrument on de evenwichtige samenstelling van relaties te onderzoeken, alsmede om de inzet van de diverse marketing(mix) instrumenten te bepalen. Zo kan een organisatie emaar streven consumenten sneller bepaalde fasen te laten doorlopen of then juist zo lang mogelijk in een bepaalde fase te laten werblijwen. Ook kan haar beleid er (mede) op gericht zijn het aantal consumenten dat de relatie verbreekt ("defectors") te minimaliseren, gelet op de empirische bevindingen van Reichheld en Sasser (1990) en Reichbeld (1996) dat de winst sterk toeneemt indien een bedrijf er in slaggt het uittreden van klanten te beperken. Om de ontwikkeling van hun relaties met afnemers makkelijker te kunnen volgen en de verdere ontwikkeling ervan beter te kumnen beheren zijn veel aanbieders direct marketing gaan toepassen en hebben zij hun eigen relatiemarketingprogramma's ontwikkeld. Direct marketing en relatiemarketingprogramma's zijn de onderwerpen van het volgende hoofdstuk.

\subsection{CONCLUSIE}

Een pure transactie is een eenmalige uitwisseling van waarden tussen twee partijen, zonder voorafgaande of opvolgende interactie. Pure transacties komen in werkelijkheid maar zelden voor en zijn in dat opzicht abstract. Zij vormen echter het beginpunt van een continuüm voor relaties en allianties en zorgen voor een bruikbaar startpunt voor theoretische analyse. Een discrete transactie vomt aldus het fundament watop een relatie gebouwd kan worden.

Een relatie wordt omschreven als een door economische en niet-economische doelstellingen geleid, direct, integrerend en op meerdere transacties betrekking hebbend interactieproces tussen een aanbieder en een consument in verband met de anschaf en het ge-/verbiuik van huishoudelijke goederen en diensten.

Indien de marketing activiteiten zich concentreren op de ad hoc transactie en de dearuit voortwloeiende ruil van een goed of dienst tegen geld, met in het algemeen anomieme klanten, dan is sprake van trawsactiemarketing.

Relatiemarketing wordt gedefiniëerd als een geïntegreerde inspanning door de organisatie teneinde een netwerk met individuele consumenten te identificeren, te behouden en op te bouwen en dat netwerk continu te versterken in het voordeel van beide partijen, door niddel van interactieve, op het individu afgestemde en watrdetoevoegende contacten die op meerdere, achtereenvolgende transacties betrekking hebben.

In tabel 2.5 worden de kenmerken van transactiemarketing en relatiemarketing kort weergegeven. 


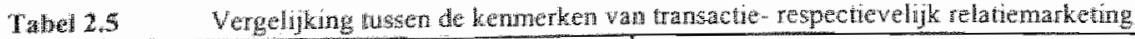

\begin{tabular}{|c|c|}
\hline Transact enarheting & Relathewarketivg \\
\hline - riadnk og cemmalige verkoop & - nadrak op behouden van klanten \\
\hline - orientatie op produk kentherker & - onenutie op produkt "benefits" \\
\hline - korte teming denken & - lange termin denken \\
\hline 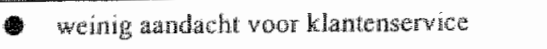 & - Wect andacht mor hanenservice \\
\hline - beperkte klamtenbinding & - grote klantenbinding \\
\hline - matig contact met klanten & - veel contact met kilanten \\
\hline - kwalleit is primatr en zorg van produktie & - kwaliter is een zorg van iodereen \\
\hline
\end{tabular}

Relaties kunnen vanuit twee invalshocken geanalyseerd worden. De eerste invalshoek let op de aard van de ruil en makt daarbij een onderscheid tussen de prestatiedinensie en de persoonsdimensie. In de prestatiedimensie staat de economische ruil (de transactie) centraal. lerwij] in de persoonsdimensie de sociale ruil. (de communicatie) centraal staat. De tweede invalshoek benadert relaties vanuit een gedragsdimensie en een belevingsdiwensie. Daarin stalan de feitelijke gebeurtenissen respectievelijk de subjectieve beoordeling van de gebeurtenissen centraal.

Het onderscheid in een gedragsdimensie en een belevingsdimensie zal ons primaire uilgangspunt zijn bij ons verdere onderzoek naar de sterkte van relaties ondat de twee invalshoeken met hun dimensies natuw met elkaar verbonden zin en veelal gezamenlijk voorkomen, alsmede ondat het in consumentenmarkten relevant geacht wordt een relatie te omschrijven op basis van de attitude en het gedrag van de consument.

Er is een onderscheid genaakt in relaties die op transacties gebaseerd zijn en relaties die op binding gebaseerd zijn. Op transacties gebaseerde relaties zijn net name op basis van de gedragsdimensie te beschrijven en te analyseren. Bij de op binding gebaseerde relatie - waarbij de binding van financiele, sociale of structurele aard kan zijn - dient bij het beschrijven en analyseren van de relatie daanaast en met name met de belevingsdimensie rekening gehouden te worden.

Een relatie ontwikkelt zich in de tijd en kan én of meerdere fasen uit de relatielevenscyclus doorlopen. Daarom is het zinvol het verloop van een relatie te volgen en te beinvloeden. Daartoe wordt meer en meer gebruik gemaakt van relatiemarketingprogramma's. Deze stellen bedrijuen in stat on directe relaties met kanten te onderhouden. 


\section{HOOFDSTUK 3: RELATIEMARKETING: STRATEGISCHE EN INSTRUMENTELE INVULLING}

Direct matheting is an ideal method to stustain and enthance the relationship beween a conpany and its customers."

(Goldberg, 1988, p. 104)

Loyaly programmes are oflen an importan part of a relationship mankering strategy. for example monetary and non-monetary rewards given for tepeat purchases, or special privileges afforded to individuals who have entered into some form of relationship with the company.

(Palmar, 1994b)

"Eine geeignete Direkmarketing-Massnahme fur den regelmässigen Iw formationsanstansch mit den Verbrawchern knn unter anderem auch die Giundung eines Clubs sein."

(Hönig, 1990, p. 20)

\subsection{INLEIDING}

In het worige hoofdstuk werd relatiematketing gepresenteend ats het concept wan watuit actwiteiten worden wernicht. Voor de strategische invuling van dat concept is het echter zank die verameling activiteiten nader te specificeren. In direct marketing (DM) stat het opbouwen, onderhouden en versterken van directe relaties centraal. Daarbij besteedt direct marketing specifick aandacht aan de invilhng vam de marketing-mix instmmenten. Eerst zal aiteengezet worden wat in ons onderzoek onder DM wordt werstan (\$3.2). Daabij zal worden aangegeven welke niveaus van DM onderscheiden kumen worden. Vemolgens zal nader

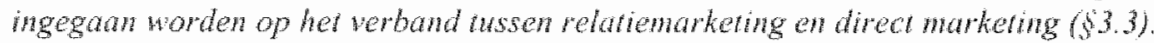

Een werschinsel warbij retatevorming hussen anbieder en consument expliciet plaasvind en warbij sprake is van directe communicatie tussen beide parijen is de klawkenclub. De klantenchb is een vorbeed wan een syshem wh verticale handelsberekkingen, "die auf

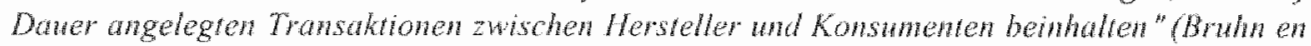
Bunge, 1994. p. 19). Andere woorbelden wan swstemen van verticale handelshetrekingen zijn

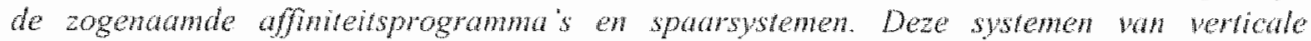
handelsrelaties worden gezamenlik wel met de term loyaliteitsprogramma's of relatienarketingprogramma's aangedud (Molenata. 1993). In 93.4 wordt een zestal relatiemarketimgprogramma's anderscheiden en kor besproken. In 83.5 wordt de andach specifiek gerich op de hlanenchiss, omdat het empirisch onderzoek binmen de context wan deze relatiemarketingprogxamma's heef plaatsgevonden. Paragrad 3 .6 wat de bolangrijkste bevindingen van dir hoofdstak kor samen. 


\subsection{DIRECT MARKETING: INHOUD EN NIVEAUS}

Net als marketing heeft DM zich primair in de Verenigde Staten sterk ontwikkeld. De eerste, van oorsprong Amerikaanse, definities van DM waren, net zoals dat bij marketing het geval was, in het algemeen (trans)actiegericht. Met andere woorden: DM-methoden en -technieken werden met name gebruikt om direct en meetbare resultaten te behalen, waarbij de nadruk lag op thet realiseren van (winst op) de transactie. Zo luidt de omschrijving van DM door de Amerikaanse Direct Marketing Association (DMA) als volgt (zie bijvoorbeeld: Baier, 1985):

"Direct marketing is an interactive system of marketing which uses one or more advertising media to effect a measurable response and/or transaction at any location".

De begrippen 'interactive", 'measurable', 'response' en 'at any location' staan in deze definitie centraal en worden geacht DM te onderscheiden van traditionele marketing. Hierover bestaat echter verschil van mening (Hoekstra en Raaijmaakers, 1991; Bauer en Miglautsch, 1992; Schofield, 1995; Tapp, 1998). Een belangrijk punt van kritiek is dat DM veelal nog steeds gepresenteerd wordt als een specifieke verkoop- en reclamemethode, die soms zelfs deel uitmaakt van de communicatie-mix (zie bijwoorbeeld Kotler, 1996). DM is inmiddels echter uitgegroeid tot een specifieke vorm van marketing, met een eigen specifieke invulling van de marketingmix.' Primair maakt DM dan ook niet deel uit van, maar vindt (al of niet geïntegreerd) plaats naast, een traditioneel marketing systeem². Als gevolg van deze ontwikkeling van DM sluiten oudere definities (zoals de vermelde DMA delinitie) niet langer aan bij wat tegenwoordig onder DM wordt verstalan. Ook de DMA-definitie beperkt DM tot een onderdeel van de communicatie-mix (Tapp, 1998). Daarnaast ontbreekt in de DMAdefinitie een belangrijk element en dat is de wens om op basis van individuele gegevens inzichi te krijgen in het gedrag en de preferenties van de klant met als doel het opbouwen en onderhouden van directe relaties (Hoekstra, 1998; Tapp, 1998). Een goede definitie van DM dient volgens Murrow en Hyman (1994) het streven naar een relatie tussen aanbieder en afnemers te bevatten. In deze studie zal DM gedefinieerd worden als (Hoekstra en Schijns, 1998):

een vorm van marketing die binnen één of meer produkt/marktcombinaties is gericht op het verkrijgen en onderhouden van directê relaties tussen een aanbieder en de afnemers. De marketingactiviteiten zijn gebaseerd op kennis van de individuele (potentiële) klanten. De marketinginstrumenten hebben een eigen specifieke invulling. Het meest kenmerkend is het hanteren wan directe communicatie en/of directe lewering.

'De ontwikkeling van DM wordt zowel door Fletcher et al. (1991) als door Hoekstra (1994a; 1995a) geschetst. Fletcher et al. onderscheiden daarbij een 'sales oriented' fase (waarin DM gezien wordt als distributiekanaal), een "image building" fase (warin DM gebruikt wordt als medium) en een 'integrated system' fase (waarin DM zowel voor het realiseren van (korte termin) tactische als voor strategische doeleinden word gebruiki. In deze fase is DM dus geïntegreerd in het algehele strategische marketing proces en streeft relaties na).

Hoekstra trekt, bij het schetsen van de ontwikkeling van direct marketing, een parallel met de ontwikkeling van markeing wan produkt(ie)concept naar strategisch marketingconcept.

${ }^{2}$ Baier, 1985; Beukenkamp en Leeflang, 1988a; 1988b; Roomer, 1990b; Bauer en Miglautsch, 1992; Hoekstra en Raajmaakers, 1991; 1992; Schofield, 1995; Tapp, 1998. 
Kenmerkend voor deze definitie zijn de volgende elementen: relaties en daamee samenhangend de kennis van de individuele klanten; produkt/marktcombinaties en marketinginstrumenten.

\section{Relaties en kennis wan de individuele klanten}

Het verknjgen en onderhouden van ditecte relaties staat centraal in onze definitie. Daarbij kan het zowel gaan on een op transacties gebaseerde relatie als om een op binding gebaseende relatie.

In het streven naar een directe relatie is het denkbaar dat de direct-marketingactiviteiten zelf op de eerstvolgende transactie zijn afgestemd. De aanbieder tracht in dat geval zijn afnemers telkens weer opnieuw te boeien met een aantrekkelijke commerciele propositie on hen te prikkelen opnieuw een aankoop te verrichten en op die manier de relatie voort te zetten. Op die manier ontwikkelt zich een op transacties gebaseerde relatie. Dit is met name het geval indien organisaties direct-marketingactiviteiten primair verrichten vanuit een interne focus: overwegingen van interne efficiency, zoals maximalisatie van de response en reductie van verspilling, zijn doorslaggevend voor het handelen van de aanbieder. Kennis van de individuela klant wordt ontleend aan inteme databronnen zoals de order-en debiteurenadministratie en is dus in het bijzonder gebaseerd op gegevens ten aanzien van het (koop)gedrag. Deze gegevens kunnen ook gebruikt worden om een beeld te krijgen van het te verwachten verloop van de relatielevenscyclus betreffende de individuele afnemer en van de economische warde die daaraan kan worden ontleend. Er bestaat echter nawwelijks of geen inzicht in de beleving van de relatie bij de klant. Een dergelijke aanpak is gerechtvaardigd indien afnemers niet of nauwelijks open staan voor een op binding gebaseerde relatie en het voor de aanbieder dus niot zinvol is daarin te investeren.

Staat de klant wel open voor binding, dan is het zinvol om bij het streven naar een directe relatie ook direct-marketingactiviteiten op te nemen waarvan de invloedssfeer verder reikt dan de eerstvolgende transactie. Met andere woorden: activiteiten die de afnemer niet ommiddellijk, maar pas na meerdere transacties een bepald voordeel opleveren en die door de afinemer dan ook zodanig gewaardeerd worden dat deze nawwelijks of niet overweegt, of anleiding heeft om, naar een andere aanbieder over te stappen (bijwoorbeeld in geval van een sparsysteem als dat van Shell). Of activiteiten die gericht zijn op het realiseren van positieve altitude-ffecien, zoals namsbekendheid, imago en vertrouwen in de anbieder, effecten die veelal dunzamer zijn dan het feitelijke gedrag (bijwoorbeeld in geval van een clubsysteem als dat van de Harley Owners Group). Daartoe zal de aanbieder moeten beschikken over kemis omtrent de klanten die voortkomt uit zowel interne als exteme databronnen. Exteme databronnen worden in het bijzonder gevormd door de klanten zelf. Middels primair onderzoek kan inzicht verkregen worden in de beleving van de relatie bij de klant. Het streven naar een directe relatie, die op binding gebaseerd is, vereist derhalve naast een inieme focus tevens een exteme focus.

\section{Produktmarkicombinaties}

Per produkt/marktcombinatie kan worden vastgesteld of de gehanteerde strategie een dinect marketing strategie zal zijn.

Indien een organisatie voor én of enkele, maar niet voor alle, produkt/marktcombinaties kiest voor een direct marketing strategie, dan is er sprake van DM op produkt/markt-niveau (Hoekstra en Leeflang, 1987b; Schijns, 1991; Hoekstra, 1998). Deze keuze heeft implicaties voor de hantering van alle klassen van marktinstrumenten. Primair is sprake van rechtstreckso 
levering on dircte communicalle. Bijvoorbeeld een organisatie die kiest voor hel rechtstreek. benaderen van ean segment en voor dit segment een strategte van DM hanteert. Zo biedt OAD Reizen via hat $100 \%$ dochter BEX Reizen busreizen aan per drect mail en direct response advertsing, en wel arr het segment dat behoete heef aan on gebruk maakt van volledig verorgde groepsneizen (veelal 55-plussers), terwijl andere segmenten door OAD 'traditioneel' (via de reisburaufomule) worden benaderd (Smeets, 1998). Andere voorbeelden zijn mel name te vinden op industriele markien, war enerzijs voor produkten die weing uitleg behoeven distribuanten worden ingeschakeld, terwil anderzijds produkten, waarvoor demonstratie en instruchie vereist zijn, rechtstreeks worden geleverd.

Indien voor alle produkt/marktcombinaties wordt gekozen voor een direct marketing strategie, dan is er sprake van DM op organisatienveau (Hoekstra en Leeflang, 1987b; Schijns, 1991; Hoekstra, 1998). Dit is de meest verstrekkende keuze voor cen strategic wan DM en heeft gevolgen voor de gehele organisatie. Voobeelden van organisaties die hiervoor hebben gekozen zijn: postorderbedrijven als Wehkamp, Neckemann en Otto; de Postbank; verakeringsmaatschappijen als Central Beheer, OHRA en FBTO; alsmede een organisatie als Reutler's Digest.

Naast DM op organisatie- en produkt/markt-niveau wordt ook nog DM op instrumentniveau onderscheiden (Hoekstra en Loellang, 1987b; Schijns, 1991; Hoekstra, 1998). Het gaat her on de minst ver doorgewoerde vorm van DM, gericht op het verknjgen en onderhouden van directe relaties tussen een aanbieder en de afnemers. Daarbij betreft het primair beslissingen ten aanzien van de hantering van éfn of meer, mar niet alle, klassen van marktinstrumenten. Ten aanzien van de klasse van instrumenten distributie of communicatie kan een DM-aanpak worden gekozen. Voorbeelden van organisaties die hiertoe behoren zijn de Bijenkorf en Procter \& Gamble. Ook de mailactiviteiten van Felix en Sheba kunnen hitrtoe worden gerekend. Twee andere voorbeelden, warop we in het kader war ons empirische onderzoek nog uitgebreid op terugkomen, zijn de rechtstreekse communicatieactiviteiten van het Gulpener Biergilde en het Gall \& Gall wijnkaarthoudersprogramma naar hun leden toe.

\section{Marketinginstrwituen}

Eerder werd reeds aangegeven dat DM als vorm van marketing kan plaatsvinden maast een tradilioned matketing systeem en een eigen specifieke invulling van de marketingmix kent. Primair makk DM dan ook geen deel meer uil wan een traditionel marketing systeem in het algemeen of van de marketingcommunicatiomix in het bijzonder. Alle instrumenten kumen op een specilieke manier worden ingezet. Kennis van de klant vormt daarbij de basis voon" bijvoorbeeld de ontwikkeling van produkten op maal en het verkrijgen van inzicht in prijselasticiteit. Het meest kenmerkend blijh echter het hanteren van directe conmunicatie enofidecte levering.

Voot de direct marketingactiviteiten op de drie onderscheiden niveaus (organisaticprodukt/mark- en instrumentriveau) wordt de tem strategische direct maketing gehanteerd (Hoekstra, 1994a; Hoekstra en Schijs, 1996). Indien er sprake is wan het verrichten van enkele direct marketingaviviteiten, of het hanteren van enkele direct narketing media, zonder een expliciete gerichtheid op het creeren van een database en het opbowwen en onderhouden van directe relaties, dan kan daarvoor in het kader van onze definitie niet langer de term direct marketing worden gebrukt, hoewel dat in de praktijk wel nog veelvuldig gebeurt. Het betren dan feitelijk cen tactische toepassing van DM-instmmenton. 


\subsection{RELATIEMARKETING EN DURECT MARKETING}

Na dit overzicht kan men zich afragen of, en $20 \mathrm{ja}$ in hoeverre, DM en relatienarketing hetzelfide zijn. Immers, DM en relatiemarketing hebben, gegeven het streven naar individuele relates, cen vergelijkbare strekking. Echter, binnen relatiemarketing word, in tegenstalling tot DM, nawwelijks aandacht besteed aan een nadere invulling van de marketinginstrumenten.

In hoofdstuk 2 werd aangegeven dat relatiemarketing streeft naar het stinuleren van het wantal herhalingsaankopen en het vergroten van de klantenbinding door relaties op te bouwen en te onderhouden met voor de organisatie belangrijke belangengroepen, zowel binnen als buiten de organisatie. Daarbij word niet aangegeven hoe dat opbouwen en onderhouden wan relaties strategisch gestate dient te krijgen. Relatiemarketing geeft daamee veeleer de managementflosofie ween wan waruit een nadere invulling gegeven dient te worden aan de marketing. instrumenter, echter zonder die inwulling middels activiteiten nader te specificeren.

DM daarentegen geef wel een eigen specifieke invulling aan de marketinginstrumenten en vereist dat de marketingactiviteiten gebaseerd zijn op kennis van de individuele (potentiele) klant. Het zijn met name de technologische ontwikkelingen, onder andere in de vorm van databases, die DM binnen handbereik wan marketeers brengen. In een database kan de direct marketeer namelijk die individuele klantgegevens vastleggen die nodig zijn on te bepalen:

- in weke fase van de relatielevenscyclus (RLC) de afnemer zich mogelijk bevind, gelet op zijn koopgedrag;

- hoe de afnemer de relatie beleeft;

- welke groeimogelijkheden en ontwikkelingsrichtingen er per klant zijn; en,

- of deze klant (eventueel samen met andere klanten) voor een speciale benadering in aammerking komt.

DM is vanuit dat oogpunt te beschouwen als een nadere strategische invulling van relatienarketing. De instrumenten van DM zijn door hun interactieve karakter voorbestemd on individuele relaties te onwikkelen (Hansen en Jeschke, 1992). Relatienarketing door niddel van DM is dan ook goed mogelijk (Peelen et al., 1987; Goldberg, 1988; Jackson, 1989 ; Bauer en Miglautsch, 1992).

Figuur 3.1 geef het verband weer tussen relatiemarketing on direct marketing. Relatiemarketing wordt gepositioneerd als de managementvisio die aangeen dat con verdedigbare concurrentiepositic bereikt kan worden indien door het tot stand brengen en: onderhouden van relaties waarde wordt gecreèd voor de kanten in de voor de onganisatio belangrijke inteme en externe belangengroepen. DM is een strategie die angeelt hoe het verkrijgen en onderliouden van directe relaties ussen aanbieder en afnemers nader ingevuld kan worden, nameljk door de marketinginstrumenten cen eigen specifieke invulling te geven (warbij het havteren wan directe communicatie en/of directe levering het meest kentmenken zijn), gebaseerd op kennis van de individuele (potentiële) klant. De marketingactiviteiten die daabinnen worden ontwikkeld, kumen in de wom van een gestructureerd programma an klanten worden aangeboden. Dergelijke klantenbindende programma's, zoals kantenclubs en spaarprogramma's, opereren dan als marketinginstrument (Holz, 1998). Zij vormen het onderwerp van de volgende paragrafen. 


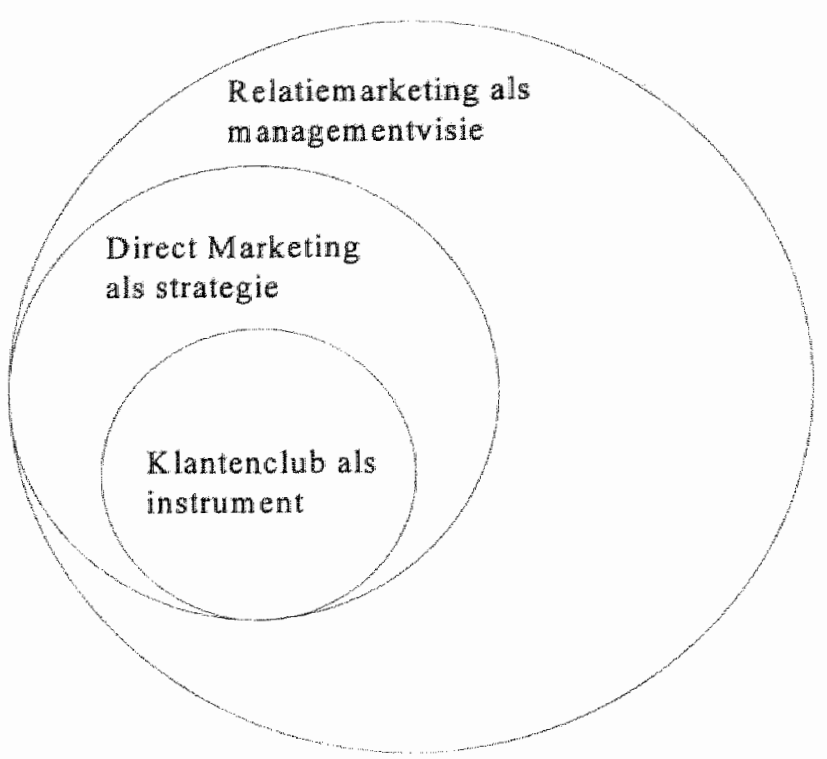

Figumr 3.1 Het verband tussen relatiemarketing, direct marketing en klantenclub

\subsection{RELATIEMARKETINGPROGRAMMA"S}

Een relatiemarketingprogramma kan gedefinieerd worden als een gestructureerd programma, bestaande uit een combinatie van marketingmix-instrumenten, dat verschillende voordelen en beloningen biedt aan (bepalde) klanten om een toegevoegde waarde van het produkt of de dienst te creëren, met als hoofddoelstellingen: klantbehoud, klantontwikkeling en relatiewersterking (Blijenberg et al., 1996). Zij onderscheiden op basis van een uitgebreid onderzoek in opdracht van de Stichting Research van de DMSA (Nederlandse Associatie voor Direct Marketing, Distance Selling en Sales Promotion) zes categorieen van relatiemarketingprogramma's (zie tabel 3.1):

(1) spaaracties; (2) spaarprogramma's; (3) affiniteitsprogranma's; (4) voordeelprogramma's; (5) clubprogramma's en (6) geïntegreerde relatiemarketingprogramma's.

De spaaractie (1) en het spaarprogromma (2) behoren tot the plain and simple points and prizes approach' (Barlow, 1992), waarbij de te verkrijgen voondelen sterk gebonden zijn aan de aankopen (Molenaar, 1993). Daarbij verkrijgt de klant een bonus woor iedere bestede geldeenheid of gekochte produkt. Deze bonus kan een premium zijn dat deel uitmaakt van een serie die verzameld moet worden (bijvoorbeeld: Flippo's), maar de bonus kan ook verstrekt worden in de vorm van zegels (bijwoorbeeld: Kristalzegels van Albert Heijn), punten (bijvoorbeeld: Douwe Egberts), coupons of welke andere promotionele rekeneenheid dan ook: (bijvoorbeeld: Air Miles). Bonussen als zegels, coupons e.d. kumen gedurende kortere of langere tijd gespaard worden en later ingewisseld worden teneinde gebruik te maken van het 
recht op een korting of antikel, al dan niet gerelateerd aan de ambieder van het relatiemarketingprogramma. Het beloningsaspect vormt het (financièle) bindmiddel. In Nederland zijn dit soort systemen zeer populair en worden toegepast door retail organisaties, benzine-, koffie- en vliegmaatschappijen. De kracht (en noodzaak) van deze strategie bleek in 1993 bij het afschaffen van het zegeltjessysteem door Shell. Terstond moest marktandeel prijsgegeven worden aan andere brandstomaatschappijen die nog wel spaarsystemen hadden. Shell was genoodzaakt op haar beslissing terug te komen en ging over tot het verstrekken van het dubbele aantal zegeltjes teneinde het verlorenterrein weer terug te winnen. Hiemil bijk tevens het gevaar dat in dergelijke spaaracties en spaarprogramma's schuilgat. Namelijk het risico dat de aanbieder niet meer kan stoppen met de actie of het programma en dat er een neerwartse spiraal ontstaat waarbij de klant slechts bereid is zijn gedrag te veranderen indien hij daamee voor de materiële beloning in aammerking komt (Kroezen, 1998). Dowling en Uncles (1997, p. 76) zeggen daar het volgende over: "For many low-inwolvement products, the incentive and not the product can become the primary reward... This might create a point of product differentiation, but once the incentive is taken away, the prime reason for purchase disappears. Many gasoline company loyalty schemes are caught in this trap, locking them onto a treadmill of continuous promotions."

De werschillen tussen de spaaractie en het spaarprogramma hebben met name betrekining op de deelnamedrempel en de termin. In geval van cen spaarprogramma wordt soms mamelijk een eigen bijdrage gevraagd, terwijl de spaaractie een beperktere tijdsdur kent dan het spaarprogramma. Indien het sparen langere tijd in beslag neemt, vindt dit meer en meer elektronisch plaats. Daarbij worden veelal ook persoonsgegevens genegistreerd, onder meer om de deememers regelmatig te kunnen infomeren over hun spaarsaldo en de bestedingsmogelijkheden daarvan (zoals bijvoorbeeld bij het Air Miles spawprogramma).

Aan spaaracties en spaarprogramma's kleven ook een aanial nadelen. Op korte termijn kan wel een voordeel bereikt worden, maar dit voordeel is veelal niet permanent verdedigbaar. Verder bestaat er een kans op vervroegde aankopen, in plaats van extra aankopen (Abraham on Lodish, 1987; Blattberg en Levin, 1987; Ehrenberg et al., 1994; Foekens, 1995). Ook is het mogelijk dat een bepaald prijsgevoelig segment wordt aangetrokken dat even zo snel weer verdwijh. Daarnaast bestaat het gevaar dat het imago bij bestaande klanten slech(er) word, ondat zij, als gevolg van de komst van dit prijsgevoelige segment, geconfonteerd worden mot langere wachttijen, drukte, langere leveringstemijnen en dus afnemende service.

Bij affiteitsprogramma's (3) is, in tegenstelling tot spaaracties en sparprogramma's, geen sprake van een eenvoudig, direct en rechtlijnig verband ussen aankoop en beloning. In tegenstelling tot spaaracties en spaarprogramma's is het beinvloeden van het koopgedrag dan ook geen primaire doelstelling van affiniteitsprogramma's. In plats van het wergaren van promotionele rekeneenheden evenredig aan het aankoopbedrag of de gekochte hoeveetheid kan er wel sprake zijn van bepaalde bestedings- of aankoopniveans die de klant dient te bereiken wil deze voortaan ook beloond worden middels een specialle behandeling, waardering en andere privileges (Barlow, 1992). De reden dit soort programma's affiniteitsprogramma's le noemen ligt dan ook met name daarin dat primair aangestuurd word op hel creëren van eon sociale binding tussen aanbieder en afnemer. Nieuwsbrieven , brochures, sponsored magazines en allerlei produktgerichte tijdschriften, die veelal gratis worden verstrekt, dragen bij aan ha informeren, waarderen en erkennen van de klant en het creëren wan die sociale binding (Molenaar, 1993). Bij deze vorm van klantenbindende programma's is het tijdselement een 
bepehere factor. Het is namelik van belang dat de activiteiten kunnen worden gestopt. Veelal is dar ook en thusfasering angegeven. Bijvoorbeeld: 'Deze actie loopt tot 31 augustus 1998 '. Ork ho op de markt brengen van een reeks van collectors items (bijoorbeeld de "Shell helpt" botkges, die handen over bepaalde, atan het produkt of merk gerelateerde onderwerpen) heef een gentinteerd karakter.

Woondelprogramma's (4). chbprogramma's (5) en gewnegreende relathenarkingprogramuma's (6) zijn vormen van 'simple memberships' (Barlow, 1992). Klanten worden uitgenodigd lid te worden van, deel te nemen aan en te genieten van de privileges van het progranma. Het is niet ongebrukelijk de deehnemers daar een vergoeding voor te vragen in de vorm van een jaarlijkse contributie. Deelnemers geven daamee aan als speciale klanten beschouwd te willen worden en zijn bereid daarvoor te betalen.

Hel voordechrogramma kent veela een kortingkaart waamee in een bepaalde winkel of groep aangesloten winkels prijsreducties op atankopen verkregen kumen worden. Voorbeelden hierwan zijn de Gall \& Gall wijnkaart en de Edah-kaart.

Het clubprogramma richt zich niet primair op het verlenen van kortingen. Indien kortingen verstrekt worden hebben die ecrder betrekking op bepaalde, aan het produkt of merk gerelateerde aankopen (bijwoorbeeld een stropdas met het logo van het Gulpener Biergille), dan op aankopen wit het kemassortiment (Gulpener bieren).

Geintegreende relatiematketingprogramma"s hebben net als voordeelprogramma"s en clubprogramma's een lange termijn perspectief. Nel als bij affiniteitsprogramma's is er bij deze programma's veelal sprake van bepaalde bestedings- of axkoopniveaus waarboven de klant beloond word middels een specialle behandeling, waardering en andere privileges, zoals betalings-, spar - krediet- en/of servicefaciliteiten. Een woorbeeld van een geïntegreerd relatiemarketingprogramma is het Flying Dutchman Programma van KLM.

Dit laatste voorbeeld geef tevens aan dat relatiemarketingprogramma's van een hogere categorie (bijvoorbeeld de categorieen 4,5 en 6, tie tabel 3.1) veelal elementen uit de lagere categorieen (bijroorbedd 1,2 en 3, zie tabel 3.1) kunnen bevatten. Daardoor zijn de grenzen tussen de diverse categorieèn niet altiju cenduidig en loopt de inhoud wan de programma"s in elkatr over. Daamee is het onderscheid tussen de diverse programma"s in de praktijk vaak niet zo cenduidig te maken als hier gepresenteerd wordt.

In de categonicen 4,5 en 6 van Blijenberg el al. (1996) is sprake van een deelnamedrempel in de vom van intekening, abonnement of lidmatschap en damee vind per defintie registratie van persoonsgegevens plaats hetgeen op het individu afgestemde communicatie mogelijk makt. Ook zijn deze latstgenoonde relaticnarketingprogramma's niet tijdelijk, maar continu van atard. Datrdoor zijn deze programma's bij uitstek geschikt voor het opbouwen van directe relaties met klanten, gekenmerk door geindiwidualiseerde communicatie. Deze typen programma's zullen in het vervolg als kantenclubs worden aangedud en dienen als kader waabinnen het empirisch onderzoek heef plaatsgevonden. Het betreft dan in het bijzonder het voordedprogramma van Gall \& Gall (wijnkaatprogramma) en het clubprogramma van Gulpener (het Gulpener Biergilde). Het voordeelprogramma van Gall \& Gall verschaft als voomamste voordeel ecn korting van $10 \%$ op wijnaakopen bij Gall \& Gall zaken en creèt in dat opzich primair en fmanciële binding en beoogt het koopgedrag positief te beïnvloeden. Het Gulpener Biergilde is expliciel gericht op het versterken van de sociale/emotionele binding met har leden. De positieve invloed op het koopgedrag wordt daarbij eerder gezien als een gevolg, dan als hot primaire doel van dit streven. 


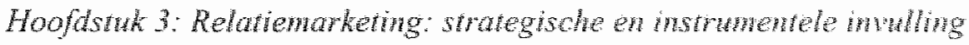

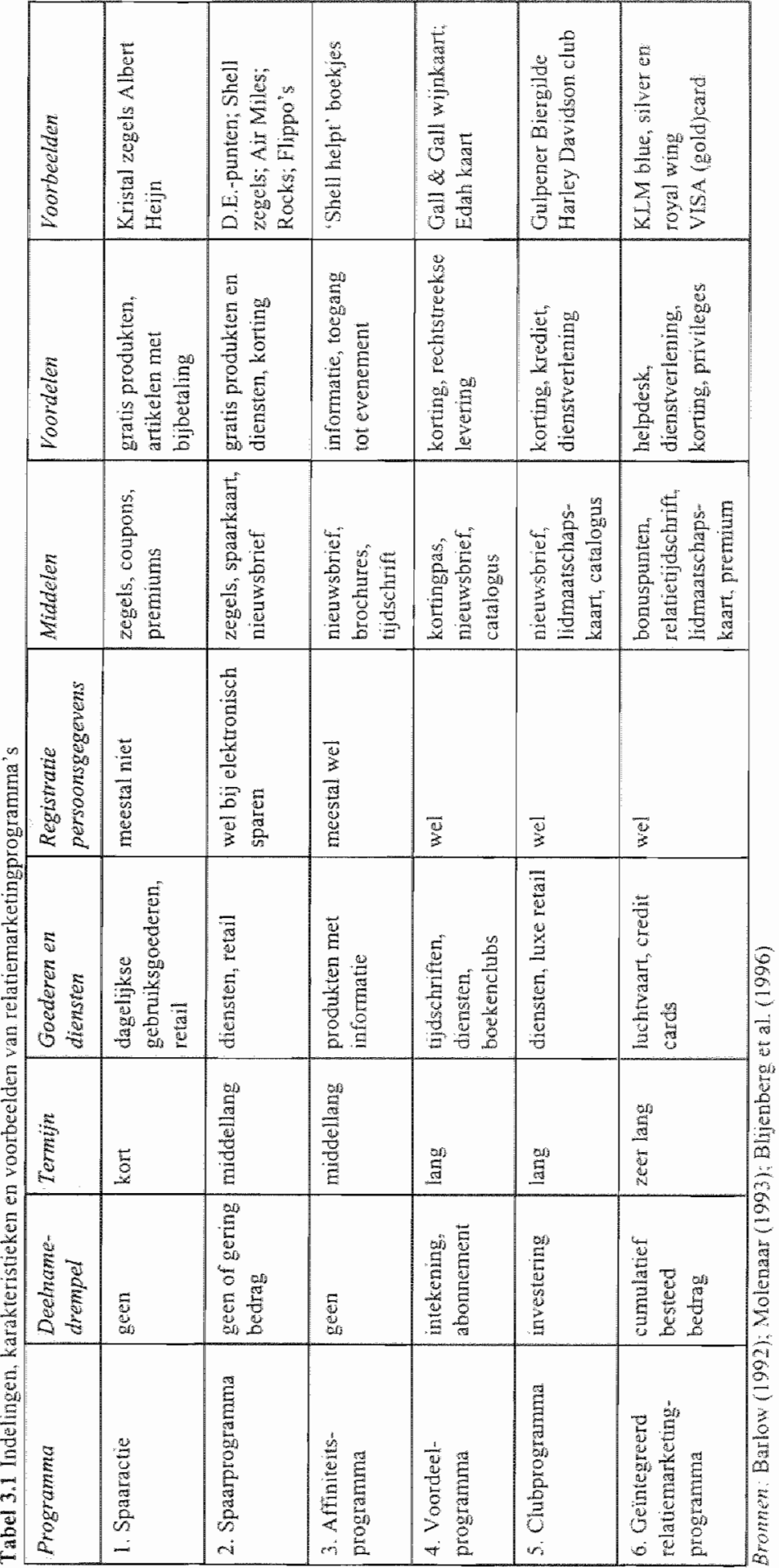




\subsubsection{DEFINUERG}

Schuring (1991) omschinft een kantenclub als ten door eén (of meerdere) aanbieder(s) georganiseerde, fictieve verenging van koopbeslissers wit een doelgroep, aan wie het lidmaatschap word aangeboden met het doel regelmatig contact met hen te onderhouden en hen te activeren. Anders dan bij een echte club komen de leden nomaal gesproken net samen en kennen akaar ook nier.

Roomer et al. (1982. p. 3.1-09) geven de volgende omschrijung van het clubconcept: "Het clubconcept is een commerciele formule, zoals het merkartikel cen commercieel idee is, dat herkenbarheid, prijs-en kwalliteisgarantie bij een loyal merkentrouw publiek probeert te vestigen om via herhalingsaankopen cen continu, vast contact met consumentengroepen te onderhouden". Het doel van een klantenclub is dus orn regelmatig contact te onderhouden met de leden, hetgeen zal leiden tot een sterkere relatie (Vavra, 1992; Butscher, 1996) en "competive hommity" in the customer base" (Gruen en Ferguson, 1994, p. 1). Het clublidmatschap van de klant is voor de aanbieder van de club dan ook niet een doel op zich, maar is een middel on andere marketing doeleinden te bereiken. Vanuit dat gezichtspunt is het lidmaatsohap met mame woor de arnbieder een hulpmiddel om een relatie op te bouwen (Gruen en Ferguson, 1994).

\subsubsection{REDENEN YOOR HET OPRICHTEN VAN EEN KLANTENCLUB}

De oprichting van een klantenclub kan om meerdere redenen verantwoord zijn (zie o.a.: Hönig, 1990; Kreutzer, 1990; Wills en Wills, 1992; Gruen en Ferguson, 1994; Diller, 1997a).

1 Kanten wordt een bizonder gevoel verschaft indien zij lid kumen worden van een (exclusieve) klantenclub. De klanten word een mogelikheid verschaft zich persoonlijk te associèren en identificeren met de overige leden of met de aanbieder. De club kan de individuele klant status werlenen en zekerheid bieden in onzekere situaties. Zeker war het persoonlijk contact ontbreekt is het essenticel de klant een gevoel var zekerheic en vertrouwen te geven. Daamee versterkt de aanbieder de klantenbinding en suggereert aldus ten opzichte wan de concurrentic cen produkivoordeel te bieden warmee (ook) de klant zich kan onderschoiden.

2 zijn de clubleden tevens teveden klanten, dan worden de voordelen van de club respectiavelijk van de produkten door hen dooverteld. Leden vervullen op die manier voor do ambieder de rol van 'Advocales' op de loyaliteitsladder en zijn ten gunste van de a anbioder in promotioneel/communicatief opzicht produktief en kostenefficient.

"De verkregen persoonsgegevens, zoals: nam, adres, woomplaats (NAWugegevens), gobootedatum on dergelijke, gekoppeld aan koopgedraggegevens stell de aanbieder in stat con specificke databank op te bouwen en darmee de effectiviteit en efficientie van zijn communicate, bijvorbeeld in de vom van direct mailings, te verbeteren. Bovendien kan

\footnotetext{
Onder een club word in het aigomeen een vrijwillige vereniging van mensen verstam, die door een geneenschappelijk interess met elkar verbonden zin. Tot de kenmerken van een club kumen worden gerekend: lidmaatschap, rumtelik trefpunt, regelmatige bijenkomsten met overige leden, gezamentijhe finamciering van activiteiten alsook oen zegrere mate van exclusiviteit. Clubs kennen in het algemeen de organisatorische vorm van en stan veelal ingeschrever als vereniging. Klantenchubs zijn in dat opzicht dan ook geen echte clubs, maar psetudoclubs (Schüring, 1991 ).
} 
de ambieder met behulp wan gegevens betreffende het koopgedrag de relatielevenscyclus analyseren. De gegevens in de database verschaffen de anbieder kemis wan de kint an geven aanleiding tot het realiseren van lagere operationele kosten.

4 De activiteiten van een klantenclub ondersteunen de publiciteit van de adnbieder. Bijzondere actriteiten van de club zoals feesten of liefdadigheidsacties laten zich relatief gemakkelijk in de media lanceren.

5 Klantenclubs helpen het marktaandeel te beschemen in markten mot meendere concurrenten. Er word als het ware monopolistische concumentie geeteerd. Het verdedigen van marktaandeel met behulp van infomatie die via de (leden van de) klantenclub beschikbaar komt en die niet woor concurrenten beschikbar is, lijkt effectiever te zin dan vomen van themareclame waarin het mek telkens weer onder de andacht wordt gebrach.

6. Door de voorturende interactie met de doelgroep kan de anbieder de acceptatio van zijn produkten door de consument continu peilen. Bovendien kunen de leden betrokken worden bij het produktontwikkelingsproces.

7 Leden zijn vak (eerder) bereid produkten te testen. hun mening daarover te geven en, bijwoorbeeld in een groepsdiscussie, toe te lichten. Hoewel chbleden mogelijk een vertekend beeld van de realiteit geven, vomen zil voor marktonderzoek een sme toegankelijke informatiebron on consumentenbehoefen op te sporen, bijvoorbectd in de vomi van een panel.

8 Tof slot vormt de klantenclub vaak een lucratieve bron van omzet voor de aanbieder. Verwacht mag worden dat de bezoekfrequentie en/of het besteed bedrag bij leden loger is dan bij miet-leden.

Deze redenen zijn voor de aanbieder/sponsor allenal rationele motieven om een marketingchb op te richten met als witeindelik doel het aantal herhalingsankopen to stimuleren en de klantenbinding te vergroten. Echter, hoe legitiem deze redenen voor hel oprichten van een klantenclub ook zijn, het is empirisch nog niet aangetoond, dat cen klantenclub aan het uteindelijke doel daadwerkelijk bijdragt. Met andere woorden: de empirische onderbouwing van het strategische effect van een klantenclub ontbreekt nog. Middels het ontwikkelen van een instrument voor het meten van relatiesterkie wil dil onderzok een bijdrage leveren an de mogelikheid he strategische offer wan oen kantanclwb empirisch te onderbouwen.

\subsection{Conclusie}

In dit hoofdstuk is DM gedefnieerd als een wom van marketing die binnen én of meer produktmarktcombinaties is gerieht op het werkrigen en onderhouden van directe relaties tussen een aanbieder en de afnemers. De natketingactivieiten zijn gebaseerd op kemm van de individuele (potentiele) klanter. De marketinginstrumenten hebben een eigen specilieke invuling. Hei meesi kenmerkend is het hanteren van directe commumicatio colof drecte levering.

Op basis van deze definitie is een drietal niveaus van DM onderscheiden, manelijk: DM op organisatieniveau; DM op produktmarktniveau, en DM op instrumentniveau. Het verband tussen DM en RM ligt daanin dat beide een wergeljkbare strekking hebben, getel op het streven naar individuele relaties. RM geef daabij het concept weer van waruit activiciten worden verricht, terwil DM die activiteiten juist specificeert. 
Een relatemarketingprogramma kan gedefinieerd worden als en gestructureerd programma, bestadnde uit en combinatic van marketingmix-instrumenten, dat verschillende voordelen en beloningen biedt aan (bepaalde) klanten om een toegevoegde waarde van het produkt of de dienst te credren, met als hoofddoelstellingen: klantbehoud, klantontwikkeling en relaticversterking.

Er kunnen in het algemeen zes categorieên van relatiemarketingprogramma's onderscheiden worden: spaaracties; spaarprogramma's; affiniteitsprogramma's; voordeelprogramma's; clubprogramma's en geintegreerde relatiemarketingprogramma's. De laatste drie categorieën werden gezamenlijk als klartenclubs aangeduid. Een klantenclub is een door én (of meerdere) aanbieder(s) georganiseerde, fictieve vereniging van koopbeslissers uit een doelgroep, aan wie het lidmaatschap wordt aangeboden met het doel regelmatig contact met hen te onderhouden en hen te activeren. Anders dan bij een echte club komen de leden normaal gesproken niet samen en kennen elkar ook niet. Bij klantenclubs is sprake van een deelnamedrempel in de vorm van intekening, abonmement of lidmaatschap en daamee vindt per definitie registratie van persoonsgegevens plaats. Ook zijn klantenclubs niet tijdelijk, maar continu van aard. Klantenclubs passen als marketinginstrument zowel binnen het kader van het relatiemarketingconcept als binnen een direct marketingstrategie. Daardoor zijn zij uitermate geschikt voor het opbouwen van directe relaties met klanten. Dat maakt deze typen programma's bij uitstek geschikt voor ons empirisch onderzoek naar het meten van relatiesterkte. De samenhang tussen de onderwerpen relatiemarketing als marketingconcept, direct marketing als marketingstrategie en de klantenclub als marketinginstrument (onderwerpen die in het algemeen afzonderlijk bestudeerd en beschreven worden), staat in niguur: 3.2 weergegeven.

RELATIEMARKETING ALS MARKETING CONCEPT (hoofdstuk 2)

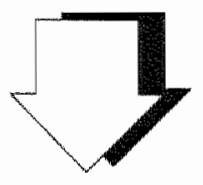

DIRECT MARETTNG ALS MARKETING STRATEGIE (paragraaf 3.2)

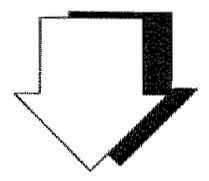

KLANTENCLUB ALS MARKETING INSTRUMENT (paragraaf 3.5)

Figur 3.2 De klantenclub als instrument ten behoeve van een direct marketing strategie, passend binnen het relatiemarketingconcept 


\section{HOOFDSTUK 4: HeT METEN VAN RELATIESTERKTE: DE BESTAANDE THEORIE}

"If yon can't measure it, you can't manage it"

Lary Ligh, DMA-congres 1996, New Orleans

\subsection{INLEIDING}

In dit onderzoek staat het onwikkelen van een instrament, dat de sterkte van de relaie (de mate wan binding) tussen consumenten en organisaties meet, centraal. Het anial onderzoeken. gericht op het meten van relatiesterkte, is gering en de wetenschapelije theorievorming op dit terrein is beperkt. Het ontwikkelen wan een valide en betrouwbar meetinstrument is alleen al on die redenen zinwol. Maar er zin nog meer redenen. Ten eerste vormt het meetinstument woor relatiestexkte een hulpmiddel bij het segmenteren en beschriven wan de makt natr (typen van) relaties. Bames (1995) steli bijoorbeeld dat hei dwideligk is da niet alle klanten een relatie willen en dat verschillende klantensegmenten verschillende vormen van relaries willen. Relatiesterkte kan naar onze mening als segmentatevariabele ingezer worden on Hantensegmenten met verschillende typen van relaties te onderscheiden die elk om een afzonderlijke benadering wagen. Segmentatie naar relatietypen heeft dus strategische beleidsconsequenties. Echter, aan segmenteren wan de mawk op basis wan (typen van) relaties is rog natwwelijks andacht besteed.

Ten tweede kan het meetinstrunent ingezet worden on de ontwikleling in relatiesterkte te volgen. Overeenkomstig de relatielevenscychs doorloopt een relatie een antal fasen, warbij de sterkte van de relatie in de fijd varieert. Het meetinstrument kan dus dienen bij het bepalen wan de fase binnen de levensowh wathin de relatie zich (bij benadeving) bevindt. Naar ankleiding daxwan kannen sirategieën, om de relatiesierkte actief te beinvloeden, witgewerkt worden. Het effect wan deze strategieen op de relavesterkte kan dan weer geneten worden. Relatiesterke kan aldus gebrukt worden wor montoring doeleinden teneinde het effect wan relatieversterkende maatregelen te volgen.

Ook kwnen met het meetinstrument de sterke en zwakke punten binnen de relatie bloorgelegd wordew. Op basis darvan kumen dan gericht acries ondernomen worden teneinde de relatie te wersterken en te bestendigen, dawel te beändigen. Een model met dawin rolatiesterkte als ahamelike variabele opgenomen kan bij deze analyse behulpzaam zijn.

Al deze redenen geven an dat het meten wan de sterkte van relaties ussen afnemens en aambieders en krachig hulpmiddel kan vormen bif het managen wan kantrelaties (Cumby en Barnes, 1996 .

In dit hooflstuk zal aandacht besteed worden aan een aantal benaderingen voor het meten wan relatiesterkte (\$4.2). Vervolgens wordt aandach besteed aan relatiemanagement, warbij relatiesterkte een belangrijk basisgegeven vorm $(\$ 4.3 \mathrm{en} \$ 4.4)$. Hoofdstuk 4 wordi afgesloten met en conchusie (\$4.5). Het wigangspunt is dus dat relatiesterkie pas adequat genanaged kan worden indien deze sterkte ook valide en betrowbaar gemeten kan worden. 


\subsection{ALTERNATIEVEN VOOR HET METEN WN RELATIESTERKTE}

\subsubsection{INLEIDING}

In deze paragraaf wordt ingegaan op mogelikheden on relatiesterkte direct of indirect (via indicatoren) te meten. Eerst worden indicatoren voor relatiesterkte geinventariseerd $(\$ 4.2 .2)$ Daarbij word een onderscheid gemaakt in gedragsvariabelen en belevingswariabelen, die in he algemeen als indicator voor relatiesterkte gebrikt worden. Vervolgens worden deze indicatorer geevalueerd. Naar aanleiding van de kritiek die ten aanzien van deze indicatoren geuit wordt worden randwoorwatden geformuleard voor het te ontwikkelen meetinstrument. In $\$ 4.2 .3$ wordt ingegaan op de relationship commitment questionmaire, als directe maatstaf voor relatiesterkte die an de geformuleerde randvoorwaarden tegemoetkomt. Tevens word relatiesterkte gedefinieerd als de sterkte van iemands identificatie met en betrokkenheid bij een organisatic.

\subsubsection{INDICATOREN}

Bij het doen wan uitspraken over de relatiesterkte tussen een leverancier en zijn afnemers wordt veelal gebruik gemaakt van variabelen die verband houden met het (koop)gedrag van de afhemers (Peelen et al, 1989; Liljander en Strandvik, 1994; Berry en Parasuraman, 1991). Enerzijde zijn gegevens ten aanzien van het koopgedrag van een klant eervoudig te verzamelen, vast te leggen en te analyseren. Anderzijds verschaffen deze gegevens informatie over het directe economische belang voor de organisatie van hel hèbben van een relatie met die kant. Deze gedragsvariabelen worden in het algeneen gebruikt als indicator voor relatiestekte. Voorbedden wan dergelijke veel gehanteerde gedragsvariabelen zijn: recentheid van de laatste aankoop, frequente van het aantal aankopen bimnen een bepaald tijdsbestek, relatieduur oftewel de duur van het klant zijn, regelmaat waarin de aankopen plaatsvinden, de monetaire waarde van de aankopen, en de breedre van het assortiment dat wordt afgenomen.

Peelen et al. (1989) geven bijvoorbeeld aan dat een hoge interactiefrequentie een sterke relatie suggeneert. Ook een geringe variantie in de regelmaat warin interacties plaatsvinden, indiceert volgens hen een sterke relatie vanwege een grotere voorspelbaarheid van toekomstig gedrag. Liljander en Strandvik (1994) suggereren een positief verband tussen de duur van de relatie en de sterkte ervan. Ook word een positief verband verondersteld tussen het bestedingsniveau en de sterkto van de relatie (Berry en Parasuraman, 1991). Tevens mag verwacht worden dat een consument niet alleen meer, maa ook meer verschillende produkten (een breder assortiment) bij eenzelfde leverancier afneemt naamate de relatie zich verder ontwikkelt (Hoekstra, 1998).

Natasl cnkelvoudige gedragsvariabelen worden, met name in de direct marketing wereld, ook wel zogenaande codes (Hoekstra, 1994a; 1998) gebruikt om een indicatie te verkrijgen van de relatiesterkte. Een code is een combinatie van een aantal gedragsvariabelen, aangezien dit type variabelen eenvondig in een electronische databank kan worden opgestagen. Een voorbeeld is do in do direct marketing praktijk gehanteerde Recency/Frequency/Monetary value (RFM) lormule (o.a.: Baier, 1985; Katzenstein en Sachs, 1992). Daarin is een aantal (enkelvoudige) variabelen samengevoegd tot én nieuw construct.

Behalve gedragsvariabelen worden ook belevingsvariabelen gebruikt als indicator voor rellatiesterkte. Voorbeelden van dergelijke belevingswariabelen zijn: tevredenheid, atractivitei, de mening over switching costs, vertrowwen, betrokkenheid en lange termijn wenwachingen. 
Dwyer et al. (1987, p. 14) bijwoorbeeld suggereren dat "the buyer's anticipation of high switching costs gives rise to the btyer "s interest in maintaining a qualiry retationship". Aldus mag verwacht worden dat gepercipieerde switching kosten en relatiesterkte een positief verband tonen (zie ook: Jackson, 1985; Sheth, 1993). Voorwaarde is wel dat de relatie net als knellend wordt ervaren als gevolg van te hoge overstapkosten. Is dat wel het geval, dan ontstat or eerder een negatieve houding ten aanzien van de relatie. De relatie wordt dan eerder voorgezet vanuit een gewoel gevangen te zijn in de relatie, dan wanuit wrije wil. Met betrekking tot lange temijn venwachingen stellen Crosby et al. (1990, p. 70) dat "low expectations of future exchange would be an outgrowth of current relational problems, whereas thigh expectations of future interchange would reflect a favorable perception of the current relationship".

Ook bij belewingswariabelen kan gebruik gemakkt worden van enkelvoudige of meervoudige indicatoren. Een voorbeeld van een meervoudige indicator is de relatie audit van Wilson. Wilson (1990) is een van de eersten en weinigen die onderzock heef gedaan dat specifick gericht was op het meten van relatiesterkte. Hij deed dit in de industriële markt, warbij hij zich in het bijzonder richtte op 'buyer-seller' of 'manufacturer-distributor' relaties. Wilson wragl zich af hoe een manager nu kan bepalen welke positie (op hel relatiecontinuum bijwoorbeeld, \$2.5) zijn organisatie inneent in de relatie met belangrijke klanten. Daarbij definieent hij niet wat een 'belangrijke' klant is, maar impliciet geeft hij aan dat een manager, op basis van bijvoorbeeld omzetgegevens, kan bepalen of een klant belangrijk is woor de organisatic of niet: De manager weet dan echter nog niet of er dientengevolge ook sprake is van een sterke of zwakke relatie. Om een uitspraak te kunnen doen ten aanzien van de sterkte van een relatie heeft Wilson een relatie audit ontwikkeld. Deze audit bepaalt de perceptie van de aanbieder ten aanzien wan de sterkte van de relatie die de organisatie met een klant heeft. Uit de audit word: tewens afgeleid of de organisatie erop is voorbereid, c.q. ervoor is toegerust, om als succesvolle partner van die klant op te treden (met andere woorden: in hoeverre de organisatie in stant is een relatie met die klant aan te gaan). De relatie audit bestaat uit een reeks vragen/items die een aantal belevingsvariabelen afdekken, zoals tevredenheid, vertrouwen, gepercipieende switching kosten en betrokkenheid; variabelen "which research has found to be critical factors in the development of relationships" (Wilson, 1990, p. 7). De som van de (i.c. twaalf) individuele itemscores (die liggen tussen 1 en 5) geeft een bervadering wan de sterkte van een relatie . Do relatie audit is opgenomen in bijlage 4. De response door de (marketing)manager vari de alanbiedende organisathe op de individuele vragen/items verschaft een indicatie van do sterke en. zwakke punten in de relatie met de klant. Op basis van de resultaten van de audit kumen programma's samengesteld worden om op de sterlkten voort te bouwen en de zwakten to corrigeren.

Bij het toepassen van zowel gedrags-als belevingsvariabelen als indicator voor relatiesterkte kan een aantal kritische kanttekeningen geplatst worden.

Ten eerste kan opgemerkt worden dat bij het gebruken van een enkelvoudige indicator, hatzij een gedragsvariabele hetzij een belevingsvariabele, de keuze woor de unteindelike varabele veelal arbitrair en op basis van intuitie lijkt plaats te vinden. Indien meerdere variabelen meegenomen worden, rijst de vraag of wel alle relevante variabellen in het meetinstrument zijn

\footnotetext{
Wilson (1990) beschouwt een totalscore tot en met 35 punten als teen indicatie voor een zwakke relatie; $36-46$ punten: gemiddelde relatie; $47-53$ punten: goede relatie; 54 tot en met het maximad te behalen aantal punten wan 60 : uitstekende relatie.
} 
wertegenwoordigd en of onder andere omstandigheden niet andere, meer, of juist minder wriabelen dienen te worden meegenomen.

Fen belangrijker punt van krthek is dat de sterkte van een relatie slechts gedeeltelijk kan worden afgeleid wit woor de aanbieder observeerbare (gedrags)grootheden: factoren als aunkoopfrequentie, omvang van de aankopen en duur van de relatie (Hoekstra, 1998). Zij geven slechts cen indicatic en zeggen in feite meer over de klant, dan over de relatie(sterkte). In de praktijk wordt cen goede (of grote) klant beschouwd als zinnde identiek aan een klant die een sterke relatic percipieert. De vraag is echter of dit terecht is. "Een goede klamt levert een relatief grote omzebijdrage per tijdseenheid. Een goede relatie is een relatie die als zodanig door de kant word ervaren" (Hoekstra, 1994a, p. 20). De sterkte van een relatie wordt in belangrijke mate bepaald door de wijze waarop de afnemer de relatie ervaart, ofwel het belang dat de afnemer aan de relatie hecht. Waar het vooral on gaat is de wijze waarop de klant de relarie beleeft (Hockstra, 1998). Of iemand een goede klant is kan veelal worden afgeleid uit (een database die gevuld is met gegevens betreffende) het koopgedrag. Or er tevens sprake is van een goede relatie kan niet direct uit (een database met daarin vastgelegd) het koopgedrag afgeleid worden. Om inzicht te krijgen in de sterkte van de relatie zoals gepercipieerd door de klant is primair marktonderzoek onder de individuele klanten nodig.

Daarmee komen we op het volgende punt van kritiek, dat relatiesterkte primair bij de klant gemeten dient te worden en niet bij de aanbieder. Ook het in beschouwing nemen van belevingsvariabelen garandeert niet dat een visie vanuit de klant wordi ingenomen. Zo werd de relatie audit van Wilson uitgevoerd onder managers an de leverende organisatie en niet onder haar klanten. Dat heeft tot gevolg dat de managers van de organisatie uitspraken moeten doen over hoe zij denken dat de klant bepaalde zaken percipieert. Zo geven zij een aordeel over de tevredenheid wan de klant met betrekking tot de prestatie van de leverende organisatie. Ook geven zij aan in welke mate de contactpersoon bij de klant, die mogelijk de relatie wil beëindigen, geconfronteerd wordt met sociale druk vanuit de klantorganisatie om dat toch vooral niet te doen. Deze invalshoek is op zijn minst niet volledig. Indien het oordeel van de klant over de relatie ontbreekt, is het immers niet mogelijk beide opvatingen ten aanzien van de sterkte van de relatie te vergelijken. Een dergelijke vergelijking is nuttig ondat deze informatie geeft over de klanten- en marktkennis bij de aanbieder, zoals dit ook in het service audit model van Parasuraman et al. (1985) het geval is. Derhalve zou ook en met name de klant an het onderzock naar velatiesterkte onderworpen moeten worden, hetgeen hierboven ook door Hoekstra (1.994a) reeds wend aangestipt. Maar ook Strandvik en Liljander (1994b) en Sheth en Parvatiyar (1995) zijn die mening toegedaan. De wederzijdse binding, zoals deze in industriele markten veelal angetroffen kan worden, ontbreekt vaak in relaties tussen consumenten en aanbieders. Om die reden is het juist in consumentenmarkten van belang relaties te omschrijven op basis van de atitudes en het gedrag van de consument, in plaats van die van de aanbieder. En daar het juist in het algemeen de klant is wiens gunst gezocht wordt, is juist zijn mening ten aamzien van de trelatie van belang (Barnes, 1995 ).

Concluderend kan wastgesteld worden dat de traditionele manieren om relatiesterkte te meten, zoals hierboven uiteengezet, nauwelijks howvast bieden en allerminst consistent zijn gelet op de gebruikte criteria en meetschalen. Naar aanleiding van het voorgaande kunnen cnkele randwoorwaarden aangegeven worden waaraan het meetinstrument dient te voldoen.

Het verdient aanbeveling op zoek te gaan naar een meetinstrument dat relatiesterkte sec, in plats van indirect via indicatoren, meet. Door gebruik te maken van indicatoren ontstat als het 
ware een vorm van instrument bias" en is de validiteit van de resultaten wak betwistbaar (Leeflang en Beukenkamp, 1981). De validiteit zal toenemen door de relatiesterkte zelf, in plaats van indicatoren te meten: "does the measure actually measure what it is supposed to measure" (Naert en Leeflang, 1978, p. 280).

Ook verdient het de voorkeur de relatiesterkte vanuit de pereptie van de klant te meten. Dat houdt dus enerzijds in dat het meetinstrument geschikt dient te zijn om primair aan de klant te worden voorgelegd en anderzijds dat het meetinstrument gericht is op het meten vam de perceptie, de attitude (bij die klant) ten aanzien van de relatie met de aanbieder.

Daamaast is het gewenst dat het instrument onder vergelijkbare onstandigheden steeds hetzelfde meet (betrouwbaarheid). Met andere woorden: ondanks (vergelijkbare) toepassingen in verschillende contexten (bijvoorbeeld werkgever-werknemer relatie versus klant-organisatie relatie) dient er van eenzelfde basis of uitgangspunt sprake te zijn (de samenstelling van de meetschaal hoeft geen drastische wijzigingen te ondergaan). Dit laatste punt geeft tevens aan dat een goed meetinstrument niet alleen tegemoetkomt an wetenschappelijke eisen als validiteit en betrouwbarheid, maar tevens praktisch toepasbaar is (Cooper en Emory, 1995 ).

\subsubsection{RELATIONSHIP COMMITMENT (RC) EN DE RELATIONSHIP COMMITMENT QUESTIONNAIRE (RCQ)}

Betreffende zijn relatie audit merkt Wilson (1990, p. 5) op dat "the dependent measure is commitment to the relationship". Indien de variabelen tevredenheid, vertrotwen, gepercipieerde switching kosten en betrokkenheid de relatie positief beinvloeden, dan is er een hoge mate van commitment. Niet alleen in studies gericht op verticale, industriele relaties ("buyer-seller relationship studies ${ }^{3}$ ) wordt commitment als afhankelijke variabele beschouwd ${ }^{2}$. Ook op het gebied van dienstennarketing wordt commitment gezien als het fundament warop relaties gebouwd worden (Berry en Parasuramen, 1991). Morgan en Hunt (1994) stellen zelfs dat commitment de centrale variabele is in elk van de tien relatievormen die zij onderscheiden (zie figuur 2.1), dus ook in relaties tussen goederen aanbiedende organisaties en hun eindafnemers, i.c. consumenten. In plaats van de eerder vermelde gedrags- en belevingsvariabelan is commitment dan ook de meest voon de hand liggende afhankelijke variabele om relatiesterkte te meten. In de makketinghteratum werd echter geen algemeen geaccepteende definitie of meetschaal voor commitment angetroffen. Dit in tegensteling toi do organisatic literatur. Daar is organizational commitment weliswaar op meerdere en verschillende manieren gedefinieerd en gemeten, de werscheidene definities en meetschalen delen echter éćn gemeenschappelijk thema. En dat is dat organizational commiment wordt beschouwd als zijnde een band of binding tussen het individu en de organisatie (Mathieu en Zajac, 1990). Het betreft dan de relatie tussen werknemer en werkgewende organisatie. Het meest bekend en toegepast is organizational commitment zoals gedefinieerd en gemeten door Porter et al. (1974, p. 604). Zij definièren organizational commitment als:

\footnotetext{
2. Jackson, 1985; Dwyer et al., 1987; Wilson en Mummalanent, 1988; Anderson en Weitz, 1989 en 1992; Wilson, 1990 en 1995; Morgan en Hunt, 1994.
} 
"the strength of an individual"s idenification with and involwement in a particular organization". Een sterke relate tusgen werknemer en werkgever wordt door drie onderling gerelateerde karkteristicken gekenmerkt: (1) een sterk geloof in en acceptatie van de doelen en waarden wan de organisatie; (2) de bereidheid om zich in te spannen voor de organisatie, en (3) een sterk verlangen om deel te blijven uitmaken van de organisatie. Om de sterkte wan de band tussen werknemer en werkgever te meten, ontwikkelden Porter et al. (1974) de zogenaamde organizational commitment questionnaire (OCQ), bestaande uit 15 items (zie bijlage 5 ).

Om en aantal redenen biedt deze $\mathrm{OCQ}$ voldoende basis voor een meetschal die gebruik kan worden voor het meten van relatiesterkte in geval van exteme belangengroepen, zoals eindafnemers. Ten eerste heeft een aantal onderzoekers (Morgan en Hunt, 1994; Kelley en Davis, 1994) de OCQ aangepast teneinde deze in een niewwe context toe te passen. In plats van het meten van de sterkte van relaties met inteme belangengroepen gebruiken zij de OCQ als uitgangspunt woor het meten van relationship commitment (RC): de sterkte van relaties met externe belangengroepen. Morgan en Hunt (1994, p. 23) definiëren relationship commitment (RC) als de overtuiging wan een ruilpartner "that an ongoing relationship with another is so important as to warrant maximum efforts at maintaining it; that is, the committed party believes the relationship is worth working on to ensure that it endures indefinitely'4. $Z_{i j}$ selecteerden wit

\begin{abstract}
${ }^{3}$ Hoewel in ae marketingliteraturr commitment en inwolwement (betrokkenheid) niet altijd duidelijk van elkaar worden onderscheiden (Bloemer, 1993) worden involvement en commitment toch vaak als verschillende begrippen gezien en gemeten. Het betreft dan wak een specifieke soort van betrokkenheid, zoals merkkeuzebetrokkenheid en produktbetrokkenheid (Mittal en Lee, 1988; 1989). De betrokkenheid bij het produkt (bijvoorbeeld een auto) en de betrokkenheid bij de merkkeuze (bijvoorbeeld Honda) zijn dan concepten die verschillen van de commitment met een specifieke aanbieder (bijwoorbeeld een platselijke autodealer). Merkkeuzebetrokkenheid en produktbetrokkenheid zijn dan inderdaad begrippen die verschillen wan commiment en kunnen verondersteld worden van invloed te zijn op (het ontstan van) commitment. Betrokkenheid (bij een organisatie) maakt in ons geval expliciet deel wit wan commitment. Met andere woorden, betrokkenheid bij de organisatie is een kenmerk van de binding met diezelfde organisatie en maakt dara ded wan wit. Zouls ate definitie al angeef, omvat commiment cehter meer dan betrokkenheid alleen.
\end{abstract}

4Hun definitie van relationship commitment slut goed an op de definitie van organizational commitment, zoals gegeven door Porter el al. (1974), met name gelet op de kemmerken (2) 'a willingness to excrt considerable effort on behalf of the organization' en ( 3 ) 'a strong desire to mantain meribership in the organization". Kenmerk (1), "a strong belief in and acceptance of the organization's goals and walues', is door Morgan en Hun (1994) als antecedent van relationship commitment opgenonen in hun model. Kenmerken (2) en (3) worden ook door Dwyer et al. (1987) en Anderson en Weitz (1992) dangeduid als belangrijke componenten van commiment. Dwyer et al. spreken in dal verband van de bereidheid om op korte termijn offers te brengen teneinde op lange termijn voordelen te realiseren. respectieveligk een impliciete of expliciete belofte de relatie te continueren. Volgens Anderson en Weitz (1992, 1). 19) omvat commitment "a desire to develop a stable relationship, a willingmess to make short-term sacrifices to mantain the relationship, and a confidence in the stability of the relationship." Ook de definities van commitment gegeven door Moorman et al. (1992), Mohr en Spekman (1994) en Gundach et al. (1995) zijn in dat opzicht consistent met die van Morgan en Huni (1994). Ondanks het veelal vage verschil tussen conmitment en gerelatecrde concepten en de vele verschillende wijzen waarop commiment geoperationaliseerd wordt. ontstant er aldus toch een basis wan gemeenschappelik inzicht in het begrip (Sölner, 1996). 
de mifuen items van de OCQ zeven items waarwan zij vonden dat deze, na ampassing, gezamenlijk als meetschaal voor Relationship Commiment gebruikt honden wotdan. Varvolgens gebruikten zij deze meetschaal (met een Cronbach alpha coëfficient wan 895 ) in hun commitment-trust theorie. Kelley en Davis (1994) modificeerden enkele items wit de organizational commitment schal on tegemoet te komen aan de context van organisatie-kiamt relaties. Zij verwijderden én item op basis wan de item-10-total correlaties. De resterende veetien items leverden en Cronbach alpha coefficient op van .86 (Cronbach, 1951), die aangeef dat de schaal betrouwbar is (Numnally, 1978; Bagozxi, 1994; Malhotra, 1996).

Tevens blijkt uit deze toepassingen door Morgan en Hunt en Kelley en Davis dat de definitie van organizational commitment ook op andere tereinen kan worden toegepast, ondanks dat de definitie betrekking heeft op "employee commitment to work organizations" (Mowday at al., 1979; 1982). Immers, ook sterke exteme relaties (relaties tussen de organisatie en exteme belangengroepen zoals weergegeven in figur 2.1) worden gekenmerkt door de drie eardet genoemde karakteristieken van commitment. Zo kan het domein van het construct worden uitgebreid naar relaties tussen een denstverlener en zijn klanten: "The employee commitment customer commitment analogy is especially relevant when one considers that service customers are often active participants in the serwice delivery process" (Kelley en Davis, $1994, \mathrm{p} .54$ ).

Een derde argument voor het gebruik van een angepaste versie van de OCQ is dat organizational commitment, zoals tot dusver besproken, gedefinieerd is als een attitude (Mowday et al., 1979; Mathien en Zajac, 1990, Geyskens en Steenkamp, 1995), hetgeen onze voorkeur heef, zoals in de vorige paragraaf aangegeven. Net als organizational commitment vertegenwoordigt relationship commitment dus "a state in which an individual identifies with a particular organization and its goals and wishes to maintain membership in order to facilitate these goals. ..., such commitment often encompasses an exchange relationship in which individuals attach themselves to the organization in return for certain rewards or payments from the organization" (Mowday el al., 1979). Bevindingen van onderzoek uitgevoerd door Denize en Young (1996) sluiten hierbij aan. Zij hebben commitment gemeten in de professionele dienstverlening: marketingmanagers die gebruik maken van de diensten van externe reclamebureaus, sales promotion organisaties of marktonderzoekbureaus. Hun commitment construct onvatte zowel een attitude component als een. gedragscomponent. Zij stelden in hun onderzok vast dat de gedragscomponent van het commitnent construct met geen van de validatiematstaven een sterk werband toonde: noch met een directe matstaf voor de mate van gepercipieerde commitment, noch met items die gericht waren op de kwaliteit van de relatie en de wens de relatie te beeindigen. De attitude component wan het commiment construct daarentegen leverde wel een significant verband op met de validatiemaatstaven: respondenten met een hoge mate van commiment hadden geen behoefte de relatie te beëindigen en gaven an zich sterk verbonden te volen met de partner. Denize en Young (1996) concluderen daaruit dat:

- de attitudecomponent en de gedragscomponent wezenlik verschillende dimensies vertegenwoordigen in de onderzochte relaties;

- dat commitment primair een attitude construct is; en,

- dat relatiesterkte het best gemeten kan worden door afnemers te vragen maar hun gevoelens ten aanzien van hun relatie met de aanbieder.

De ontwikkeling van een attitudinal relationship commitment meetschaal bied wolgens hen dan ook mogelijkheden om als hulpmiddel te woorzien in de behoefte van managers tot het monitoren van relaties met afnemers. 
Voortvloetend uit hel voorgaande betoog zullen wij relatiesterkte (relationship commitment), op basis van de definite van attitudinal organizational commitment, definieren als:

de sterkte wan iemands identificatie met en betrokkenheid bje en organisatie.

Deze sterkte zal middels de relationship commitment questionnaire (RCQ), een aan de marketingsituatie aangepaste versie van de organizational commitment questionnaire, gemeten worden. Dit meetinstrument komt tegemoet aan de in de vorige paragraaf geschetste randvoorwaarden. Ten eerste meet het relatiesterkte direct, in plaats van indirect (via indicatoren). Ten tweede is het meetinstrument geschikt om primair aan de klant te worden voorgelegd en ten derde richt het meetinstrument zich op het meten van de perceptie, de attitude (bij die klant). Daarnaast kan het instrument onder vergelijkbare omstandigheden toegepast worden zonder dat de samenstelling drastische wijzigingen behoeft te ondergaan. Met andere woorden: het instrument is eenwoudig in de praktijk toepasbaar, en ondanks toepassingen in verschillende contexten is er van eenzelfde basis of uitgangspunt sprake. Op basis van het voorgaande wordt de volgende hypothese geformuleerd:

Hypothese 1 De relationship commitment questionnaire (RCQ) is een betrouwbare en valide meetschaal voor het vaststellen van de sterkte van relaties tussen een aanbieder en zijn eindafnemers, i.c. consumenten.

De wijze warop relatiesterkte ten behoeve van ons empirische onderzoek geoperationaliseerd wordt, zal in het volgende hoofdstuk uiteengezet worden. Nu zal eerst worden aangegeven op welke wijze relatiesterkte een bijdrage kan leveren aan relatiemanagement doeleinden. Daartoe zal eerst worden ingegaan op het segmenteren, beschrijven en monitoren van relaties, mede op basis van de sterkte van de relatie (\$4.3). Daarmee wordt het belang van het ontwikkelen varn een meetinstrument nader aangetoond. Immers, indien we beschikken over een instrument voor het meten van relatiesterkte, zijn we in stat de effecten van eerder genomen welatieversterkende maatregelen te analyseren en beslissingen te nemen ten aanzien van toekomstige relatieversterkende activiteiten zodat de relatie zich in de gewenste richting ontwikkelt. Vervolgens word gekeken nat de factoren die van invloed zijn op relatiesterkte, tencinde toekonstige relatieversterkende activiteiten en beoogde ontwikkelingsrichting van de relatie meer fundament te bieden $(\$ 4,4)$.

\subsection{SEGMENTEREN, BESCHRIJVN EN MONITOREN VAN RELATIES}

In hoofdstuk 2 is vastgesteld dat een relatie zowel een gedragsdimensie als een belevingsdimensie bevat. Voor het segmenteren, beschrijven en monitoren van relaties dienen dan ook beide dimensies in beschouwing genomen te worden. Vanuit een managementperspectief worden belevingsvariabelen opgenomen om de mogeljjkheden voor het opbouwen van een relatic met de afnemer te onderzoeken, terwijl gedragsvariabelen gebruikt worden on te achterhalen of het economisch verantwoord is in een eventuele relatie te investeren. In de literatur is een aantal modellen, dat deze beide relatiedimensies combineert, aangetroffen. Het betreffen de relatieportfolio van Wilson (1990), de relationship type matrix van Krapfel et al. (1991), de klant-relatie matrix van Hoekstra (1998), de relationship strength 
matrix van Strandwik en Liljander (1994b) en de relative attitude-behavior relationship van Dick en Basu (1994), Deze modellen zullen in deze paragraaf achtereenvolgens behandeld worden. De sterke punten van deze modellen vormen de basis voor ons RLM-model: een model warin relatieperceptie en loyaliteit in de vorm van een matrix gepresenteerd worden.

\section{De relatieportfolio van Wilson}

Wison (1990) makt een onderscheid tussen de belangrikheid c.q. de warde van een kiant woor de organisatie enerzijds en de mogelijkheid on en relatie te ontwikkelen mel die klant anderzijds. Dit onderscheid wordt weergegeven met behulp wan figuur 4.1.

Company's ability to

develop relationships

with the customen

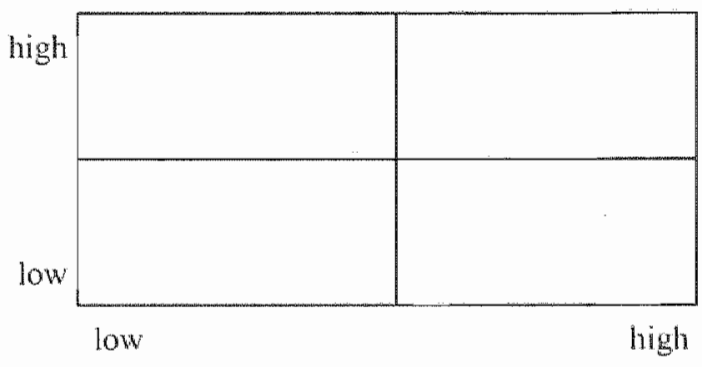

Importance and value of the account to the company

niguur $4.1^{5}$ De relatieportfolio volgens Wilson (1990)

In figun 4.1 kunnen klanten in vier cellen gepositioneerd worden, gebaseerd op hun belangrijkheid voor de organisatie en het vermogen van de organisatie om met de klant een relatie aan te gaan. Daartoe is de eerste stap die door de manager genomen moet worden, het verifièren van alle wardevolle en belangrijke klanten en potentiële klanten. Daarbij geeft Wilson (1990) niet aan wat een 'belangrijke' klant is, mat impliciet duidt hij or op dat cen manager, op basis van bijvoorbeeld omzetgegevens, kan bepalen of een $k$ lant belangrijk is woor de organisatic of niet. Vervolgens worden deze klanten verder witgesplitst op basis van het vermogen van de organisatie om met deze klanten een relatie aan te gaan. Wilson verzuiml exact aan te geven wat hij bedoelt met "Company's ability to develop relationships with the customer", maar uil de context blijkt dat hij daamee bedoelt weer te geven de polentie om met een kant een relatie aan te gaan op basis van de huidige relatiesterkte alsmede de mogelijkheden voort te bouwen op de sterke punten en het corrigeren van de zwakke punten in de relatie. De huidige relatiesterkte en de sterke en zwakke punten in de relatic worden vastgesteld met de eerder vermelde 'relationship audit' $(84.2 .2$, zic ook bijlage 4 ) en vomen het uritgangspunt voor de genoemde potentie.

\footnotetext{
${ }^{5}$ De in dit hoofdstuk opgenomen figuren, die alle in de vorm van een matrix zijn weergegewen, zijn voorzover nodig aangepast, zodat hun dimensies in dezelfde riching wijzen. Ook zajn de meesi met elkar overeenkomende dimensies op dezelfde as geplaatsi. Daarmee zijn de figuren beler we interpreteren en te vergelijken dan wanneer wij ons hadden gehouden aan het oorspronkelijke assenstelsel. Inhoudelijk is er echter niets veranderd.
} 
Alleen de klanten die tot de cel rechtshoven behoren zouden de primaire doelgroep moeten zin voor relaticontwkeling, omdat deze klanten belangrijk zijn en mogelikheden bieden voor verdere relatie ontwikkeling. De belangrike klanten warmee minder makkelik cen relatie kan worden opgeboumd (cel rechtsonder) dienen nader onderzocht te worden teneinde te achterhalen welke actie ondemomen moet worden om de mogelijkheid met deze klanten een relatie op te bouwen, te verbeteren. Indien er weinig of geen mogelikheden zijn om cen relatie op te bouwen kumnen er toch zaken gedaan worden met de klant, zij het op een meer traditionele transactiebasis.

\section{De relationship type matrix van Krapfel et al.}

Krapfel et al. (1991) hanteren cen overeenkomstige benadering als Wilson, in die zin dat zij tot een vergehjkbare matrix komen, gebaseerd op onderzoek bij de aanbieder naar hoe deze denkt dat de klant bepaalde zaken percipieert. Daanaast passen zij, net als Wilson, de gedachte van de portfoliomanalyse benadering toe op buyer-seller relaties. Op basis van de dimensies relatiewarde ("relationship value' (RV)) en de overeenstemmende belangen tussen beide partijen ('interest commonality" (IC)) onderscheiden zij vier relatietypen (zie riguur 4.2)

$\mathrm{RV}$ is de economische warde van de relatio voor de verkoper en is een functie van "criticality" (C), "quantity' (Q), "replaceability' (R) en 'slack' (S). Criticality betreft de mate van substitueerbaarheid van een goed of dienst, alsmede de contributiemarge van het produkt. Kopers die produkten afnemen, die moeilik elders te verkijgen zijn en een hoge contributiemarge hebben, vertegenwoordigen een grotere waarde voor de verkoper dan kopers van produkten die makkelijk te substitueren zijn en een lage contributiemarge hebben. Overeenkomstig worden kopers van grote hoeveelhoden (Quawity) hoger gewaardeerd. Replaceability geef aan het gemak wammee een afnemer kan worden vervangen door een andere koper en komt met name tot wildrukking in de switching kosten woor de verkoper. Slack houdt in dat een koper bijvoorbeeld zelf woorrad aamhoudt, waardoor de verkoper kosten bespaart daar hij schokken niet alléen hoeft op te vangen. Ook het prompt betalen van rekeningen en het lijdig verstrekken van afzetvoorspelingen door de koper, alsmede het participeren in geautomatiseerde bestelprocedures veroorzaken sllack bij de verkoper. Kopers zijn waardevoller naamate zij een grotere bijdrage leveren aan het realiseren van kostenbesparingen bij de varkoper. Deze vier factoren bepalen de mate warin de verkoper afhankelijk is van de koper. Met andeve woorden: naammate de verkoper afhankelijker is van de koper, op basis van C, Q, R en S, impliceent dit dat de koper een grotere waarde vertegenwoordigi voor, oftewel belangrijker is voor, de verkoper, met het oog op het vooribestan (continutieit) van dere laatste.

IC reflecteent de economische doelen van de aanbieder en zijn perceptie ten aanzien van de economische doelen van zijn handelspartner. Indien de economische doelen van koper en verkoper overeenkomen is de IC hoog.

Op basis van deze twee dimensies onderscheiden Krapfel et al, (1991) vier soorten klanten: de "partner", de 'rival', de 'Griend" en de 'acquantance". Met elk van deze klantensoorten onderhoudt de organisatie een specifieke relatie. 
Interest Commonality,

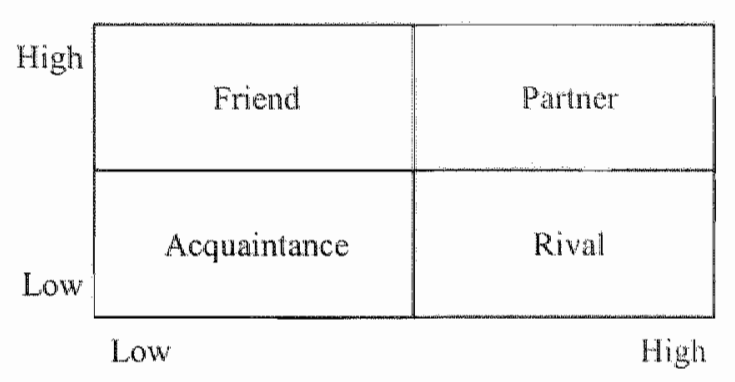

Relationship value

$R V_{i}=\left[C_{j}, Q_{j}, R_{j}, S_{j}\right]$

\section{Legenda:}

$\mathrm{RV}_{i}=$ relationship value, de economische warde van de relatie voor verkoper $\mathrm{i}$

$\mathrm{C}_{\mathrm{j}}=$ criticality, de substitueerbaarheid en contributiemarge van het door koper $\mathrm{j}$ gekochte goed

Q.j = quantity, de hoeveelheid output van de verkoper, geconsumeend door koper j

$\mathrm{R}_{\mathrm{j}}=$ replaceability, de vervangbarheid van koper $\mathrm{j}$ (d.w.z. de switching kosten om tot andere kopers toegang te krijgen)

$\mathrm{S}_{\mathrm{j}} \quad=\quad$ slack, de kostenbesparingen als gevolg van de handelwijzen en procedures van koper j

Interest Commonality $y_{i}$ de mate warin, wolgens verkoper $i$, de economische doelen van verkoper en koper met elkaar overeenkomen

Figuur 4.2 De Relationship Type Matrix van Krapfel et all. (1991)

Partyers zijn afnemers met een hoge economische relatiewarde en een sterke overeenkomst betreffende de economische doelen. Er is sprake van (mogelijk wederzijdse) allankelijkheid tussen aanbieder en partner (op basis van $\mathrm{C}, \mathrm{Q}, \mathrm{R}$ en/of $\mathrm{S}$ ). De aanbieder is veelat bereid to inwesteren in het op de afnemer afstemmen van bijoorbeeld produkten, bestel en leverprocedures (customisation). Daartoe wordt informatie onderling uitgewisseld en gedeeld en neent de athankelijkheid verder toe en stijgen de switching kosten.

Frienden zijn afnemers met een lage (huidige) economische relatiewarde. Desalniettemin neemt de verkoper een sterk gemeenschappeljk belang waar. Er is weliswaar sprake van het delen en uitwisselen van informatie, maar slechts van beperkte investeringen. Hoge inwesteringen (teneinde de relatie te koesteren) verminderen de contributiemarge (die mogelijk toch al laag is) immers verder.

De relaties die met rivalen onderhouden worden, moeten weliswaar gecontinueerd worlen (xij vertegenwoordigen immers een hoge economische relatiewaarde), maar zonder hierin al te grote transactiespecifieke inwesteringen te doen danwel al te klantgericht bezig te zijn (duar hun interessen niet overeen komen met die van de aambieder). Rivalen kumen zowel klant als concurrent blijken te zijn. Rekening moet worden gehouden met de serieuze mogelijkheid dat de relatie beëindigd dient te worden. De kans is immers groot dat rivalen zaken doen ondat zij moeten, eerder dan omdat zij willen. Om die reden zijn beide partijen dan ook veclal op zock 
naar cen andere partner en hebben plannen om de relatie met de hudige "tegenpartij" te verbreken.

Kennissen ("acquaintances') dienen benaderd te worden met gestandaardiseerde produkten en routinematige procedures. Specifieke investeringen ev/of een klantgerichte anpak worden vooralsnog niet terugverdiend. Grote aantallen van dit relatietype vragen om een meer intensieve en indirecte distributie in plaats van directe distributie. Kennissen kunnen echter woor lange fijd als handelspartner aangehouden worden, om reden van vemindering van de strategische kwetsbaarheid, waarborgen van geografische marktoegang of om de potentie om uit te groeien tot vriend of partner te kumen inschatten.

Net als Wilson gaan ook Krapfel et al. er van uit dat de relatie audit aan (managers van) de aanbieder word voorgelegd. Zoals ecrder opgemerkt is deze invalshoek op zijn minst onwolledig. Het zou met name de klant moeten zijn die aan het onderzoek naar relatiesterkte onderworpen wordt. Deze weede invalshock wordt verwolgens besproken.

\section{De klant-relatie matrix van Hoekstra}

Het onderscheid fussen een goede klant en een goede relatie wordt door Hoekstra (1998) ondergebracht in een 'klant-relatie matrix', zoals weergegeven in figuur 4.3. Een goede klant word door hatr omscheven als een klant die een relatief grote omzetbijdrage per tijdseenheid levert (kwaliteit klant = hoog). Een goede relatie is een relatie die door de klant als sterk wordt ervaren (aard relatie = sterk). De sterkte van de relatie wordt dus bepaald door de wijze waarop de klant de relatie beleeft.

\begin{tabular}{|c|c|c|c|}
\hline & & \multicolumn{2}{|c|}{ kwalleit klant } \\
\hline & & laag & hoog \\
\hline \multirow[t]{2}{*}{ Aard relatie } & sterk & 2 & 1 \\
\hline & zwak & 4 & 3 \\
\hline
\end{tabular}

\section{Figuur 4.3 De Klant-Relatie Matrix volgens Hoekstra (1998)}

Tot cel / behoren de goede klanten met wie en sterke relatie is opgebouwd. Ondanks de geringe kans dat deze klanten naur een andere aanbieder overstappen, moeten deze klanten gekoesterd worden ondat zij cen grote omzetbijdrage leveren, bereid zijn dit te blijven doen en als referentie of ambassadeur optreden. Klantbehoud is hier de hoofdzaak.

De kwaliteit van de klanten in cel 2 is minder goed tot slecht, maar de klanten ervaren wel een sterk relatie mel de organisatie. Het vertrouwen in de organisatie is dus blijkbaar wel anwezig, maar komt (nog) niet tot uitdrukking in het koopgedrag van deze klanten. Het is dus zatak on, gebaseerd op deze sterke relatie, deze klanten op temijn in goede klanten te transformeren, bijvoorbeeld door cross sell activiteiten wardoor de omzetbijdrage positief beinvloed wordt.

Met betrekking tot de klanten in cel 3 is het van belang de relatie met deze klanten te versterken. Hierdoor ontstaat er een grotere concumentie-immuniteit. In het geval de organisatic dan eens een steekje laat wallen, betekent dit niet onmiddellijk dat een belangrijk deel van de omzet van de organisatie in handen wan concurrenten terechtkomt, omdat de klant bereid is deze "misstap' te accepteren. 
In de klanten die aan cel 4 worden toegeschreven moet niet teveel geirvesteend worden. Het is namelijk nief zeker of die investering terugverdiend wordt. De database kan cen indicatie geven van de fase in de relatielevenscyclus warin de kant zich mogelijk bevindt. Op basis daarwan kan bepaald worden of het beter is de relatie met deze klant te beeindigen, danwel of het mogelijk is deze klant, daartoe gestuurd door gepaste marketingactiviteiten, op termijn to veranderen in een goede klant (cel 3), of in een klant met een sterke relatie (cel 1 ol 2 ).

In de cellen 3 en 4 kunmen de zogenaande prijskopers ("economy shoppers') verwacht worden. Prijskopers willen zich niet binden aan een aanbieder en zijn continu op zoek naar de ambieder met de beste prijs/waarde verhouding (Peelen, 1990a). Naar aanleiding daarvan zal hat warschijnlijk geen winstgevende activiteit zin om te proberen een relatie met prijskopers op to bouwen en te proberen hen te binden. De relatie, die zich hieruit ontwikkelt, zall waarschijnlijk een andere invulling hebben. Er zal eerder sprake zijn van een op transacties gebaseerde relatie (in de zin van herhalingsaankopen) dan van een op binding gebaseerde telatie.

Tot nog toe wordt bij de strategiebepaling veelal uitsluitend gekeken naar de "kwaliteit" wan de kant (Hoekstra, 1994a). Het gebruiken van de klant-relatie matrix kan dan lot andere inzichen leiden en tot andere beleidsbeslissingen aanleiding geven. Gebruik maken van deze matrix impliceert immers dat niet alleen naar de klantkwaliteitsdimensie wordt gekeken (uitgednukt in bijwoorbeeld het geldbedrag dat de klant genereert), maar ook naar de aard van de relatie zoals de klant deze beleeft. Enerzijds getuigt de aanbieder wan een klantgerichte instelling, door de perceptie van de klant ten aanzien van de relatie met de aanbieder in beschouwing te nemen. Anderzijds kan de aanbieder bedrijfseconomisch verantwoord investeren in de relatie, daat hij het (koop)gedrag van de klant kent. Per cel zal een verschillende strategie gehanteerd kunnen worden. Daartoe is meer kennis vereist betreffende de aard van de relatie. Echter, resultaten van onderzoek die een beter inzicht bieden in de aard van de relatie (sterk of zwak), uitgande wan de perceptie van de klant/consument, zijn niet of nauwelijks voorhanden. Als uilzondering daarop kan het werk van Strandvik en Liljander (1994b) genoemd worden.

\section{De relationship strength matrix van Strandvik en Liljander}

Strandvik en Liljander (1994b) hebben in Finland een kwalitatieve studie gedaan betreffonde do relaties van particulieren met banken. Het betrof 27 diepte interviews mot clienten van verschillende banken. De interviews hadden betrekking op de huidige relatie met hun primaire bank. Deze empirische studie is naar hun mening een eerste stap in de richting van do ontwikkeling van een onderzoeksinstrument voor relatiesterkte. Ook zij hadden geconstateerd dat slechts weing bekend was over hoe consumenten in feite hun relate met dienstverlenende bedrijwen percipièren. Daarom achtten zij het noodzakelijk een kwalitatieve studie te doen teneinde een beter begrip van het fenomeen te verkrijgen. Daartoe maken zij gebruik van de begrippen "relationship commitment" en "relationship loyally".

Relationship commiment wordt door hen gedefinieerd als de mate warin de klant de voorkeur geeft aan een specilieke bank en positief over de bank spreekt (optreed als referentie of ambassadeur). Daarbij onderscheiden zij drie typen van commitment. Positief commitment als de klant een positieve houding heeft ten aanzien wan de bank en er positief over spreekt. Negatief commiment indien de klant teleurgesteld is en/of negatief over de bank spreekt. Tenslotte kan de klant een neutrale houding hebben.

Relationship loyaly kan volgens Strandvik en Liljander op meerdere manieren gedefineerd en gemeten worden. Bijwoorbeeld als het aantal bankrelaties, gebruiksintensiteit (te vergelijken 
met frequentie van gebruik, gebruksconcentratie (te vergelijen met regelmat van gebruk dun van de relatic, of betuigde loyaliteit. Betugde loyaliteit wordt daarbij gedelinieerd als d door de kint gepercipicerde en verbaal uitgedrukte loyaliteit en word in casu weergegeve middels de mate watin de klant overwogen heeft een overstap natar cen andere bank te maker Hogere relatieloyaliteit wordt dan gekenmerkt door minder bankrelaties, hoger gebruksintensiteit, grotere gebruiksconcentratie, langere relaties en/of een hogere betugd loyaliteit. In hun onderzock hebben Strandwik en Liljander de respondenten gecategoriseer overeenkomstig de betuigde loyaliteil enerzijds en commitment anderzijds. Op basis van dez twee dimensies komen zjy tot hum "relationship strength mairix" (zie figutir 4.4).

\begin{tabular}{|c|c|c|c|}
\hline & & \multicolumn{2}{|c|}{ Relationship loyally to main bank } \\
\hline & & $\begin{array}{l}\text { Has considered } \\
\text { changing }\end{array}$ & $\begin{array}{c}\text { Has never considered } \\
\text { changing }\end{array}$ \\
\hline \multirow{3}{*}{$\begin{array}{l}\text { Relationship } \\
\text { commitment }\end{array}$} & Posilive & $B$ & A \\
\hline & Indifferent & $\mathrm{D}$ & $C$ \\
\hline & Negative & $\mathrm{F}$ & $\mathrm{E}$ \\
\hline
\end{tabular}

Figuur 4.4 De "relationship strength matrix" van Strandwik en Liljander (1994b)

Wit de matrix blijkt dat een hoge mate van loyaliteit (cellen A, C en E) alijid aanwezig kan zijn: onahankelijk van de mate van relationship commitment. Met andere woorden: de mate van loyaliteit hoeft niet per definitie overeen te komen met de mate van relationship commitment. Loyaliteit en commitment vertegenwoordigen verschillende dimensies.

Het onderscheid in zwakike en sterke relaties sluit aan bij het verschil tussen herhalingsatankopen ('spurious loyalty') en echte merktrouw ("true loyalty") (Bloemer, 1990; 1993a), alsmede bij het verschil tussen "spurious relationship" en 'true relationship" (Poiesz en Van Raviij, 1993). Dit onderscheid tussen spurious en true loyalty komt ook terug in de "relative athitude - behavior relationship' van Dick en Basu (1994).

\section{De "relative atitude-behavior relationship" van Dick en Basu}

Dick en Basu (1994) stellen dat customer loyalty een combinatie is van een belevingsdimensie ("relative attitude") en een gedragsdimensie ("repeat patronage"). Zie figuru 4.5. Hun model vertoont sterke overeenkomsten met de eerder besproken modellen van Wilson, Krapfel et al., Hoekstrw, alsmede Strandvik en Lillander. De gedragsdimensie wordt geoperationaliseerd middels koopgedraggegevens. De belevingsdimensie wordt geoperationaliseerd door "relative attiude" warmee de antrokkelikheid van de aanbieder ten opzichte van altematieve aanbieders tot uitdrukking komt. Met betrekking tot 'relative attitude' merken Dick en Basu (1994, pp. 100 101) op dat "Antudes have been related to behaviors, although it is important to note that one may hold a favorable attitude toward a brand but not purchase it over multiple occasions because of comparable or greater attitudinal extremity toward other brands". 
Relative Attitude

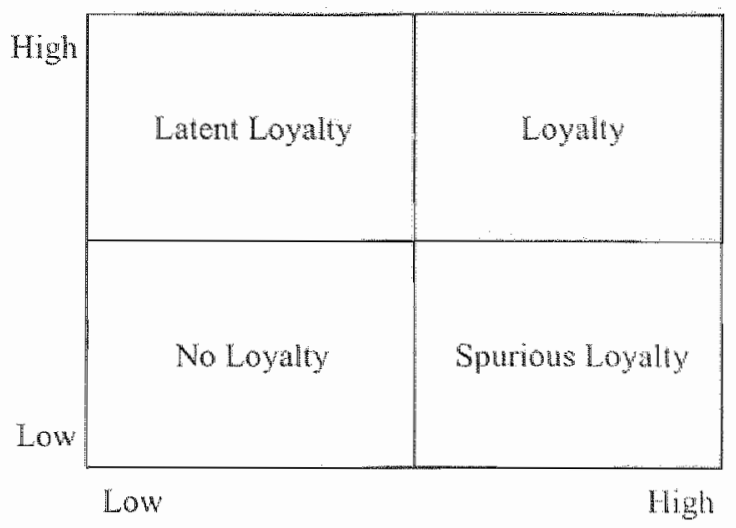

Repeat Patronage

Figuur 4.5 De 'Relative Attitude-Behavior Relationship' wan Dick en Basu (1994)

Vandaat dat Dick en Basu de voorkeur geven aan een relatieve attitude boven een absolutc attitude. Bij deze laatste vindt geen vergelijking plats tussen merken, die door de consument in een bepaalde consumptie context relevant geacht worden. Dick en Basu verwachten dat de relatieve attitude een sterkere indicator c.q. voorspeller is voor herhaald aankoopgedrag, dan de attitude die in isolatie wordt vastgesteld ondat een afnemer ten aanzien wan meerdere aanbieders een positieve, absolute atitude kan hebben. Herhalingsaankopen zullen dan met nane bij die aanbieder plaatsvinden jegens wie de meest positieve attiude bestat, met andere woorden bij die aanbieder, die volgens de mening van de consument het meest aantrekkelijk is.

\section{Het RLM-model}

Het onderling vergelijken van de voorgaande modellen levert een aantal overeenkomsten en verschillen op. Overeenkomsten en verschillen die adnleiding geven to de introductic wan cen aangepast model, dat in de praktik toepasbaar is en tot een bruikbare klantenindeling kom.

\section{Owereenkomsten}

Belangrijk is te constateren dat uit de besproken modellen van Wilson, Krapfel al al. Hockstra, Strandwik en Liljander en Dick en Bast duidelik wordt dat elk model zowel een gedrags als een belevingsdimensie kent. De besproken modellen duiden daanee expliciet op het belang van het gebruiken van belewingsvariabelen bij het segmenteren, beschrijven en monitoren van (relaties met) afnemers, naast gegevens ten aanzien van het (koop)gedrag. Daamee wordt beoogd de invulling van de marketing en communicatiestrategie niel allech te laten plaatswinden op basis van aspecten die het koopgedrag van de klant bepalen (gedragsdimensio), maar ook op basis van de wijze warop een klant de relatie beleeft (belevingsdimensic)

Ten aanzien van de nadere operationalisering wan de gedragsdimensie blijkt er cen bepaldo mate van uniformiteit in deze modellen te bestaan. En wel in die zin dat de aanbioder uit specifieke (koop)gedraggegevens (die hij zelf kan bepalen) dient af te leiden of het bedrijfseconomisch gezien voordelig is een relatie met een klant to onderhoudon on zo ja, in welke vorm. 


\section{Verschilen}

De serschillen in de voorgande modellen hebben met name betrekking op de belevingsdimensic en de operationalisering daarwan. Daar is namelik minder unifomiteit in de modellen te constatern. De belevingsdimensie krijgt in elk model, middels een ander concept, een andere invuling. Daat war" gerefereed wordt aan "relatiestekte" (Wilson, 1990; Hoekstra, 1998; Strandvik en Liljander, 1994) word deze op verschillende wijzen gemeten. Wilson mask gebruik van indicatoren woor relatiesterkte (zoals: tevredenheid, overstapkosten, wertrouwen en betrokkenheid, zie \$4.2.2). Strandvik en Liljander beperken zich tot kenmerken van een sterke relatic (vootkeur hebben voor en positiel spreken over i.c. een bank), en Hoekstra opertionaliseert de alard van de relatie ( $5 t e r k / 2 w a k$ ) niet.

De mate warin (i.c. economische) doelen van koper en verkoper met elkarr overeenkomen ('interest commonalily", Krapfol el al, 1991), is cen belangrijke voorwarde voor de acceptatie van de doelen en waarden van de wederpartij en is in dat opzicht eveneens een belangrijk kenmerk wan rolatiesterkte, maar meet relatiesterkte zelf niet.

"Relative attitude" van Dick en Basu (1994) is eveneens weinig concreet en biedt daardoor weinig houvast on tot een bruikbare operationalisatic te komen. Dick en Basu operationaliseren deze variabele niet.

Een ander punt van verschil is dat de houding van de klant ten aanzien van de relatie in het model van Wilson en de mate waarin de economische doelen varn verkoper en koper met elkaar overenkomen in het model van Krapfel at al. gemeten worden bij de aambieder. Dit in tegenstelling tot de modellen van Hoekstra, Strandvik en Liljander en Dick en Basu, waar de perceptie ten aanzien van de relatie bij de klant en wanuit zijn gezichtspunt gemeten wordt. Deze laatsto benadering heef, zoals eerder aangegeven, met name in een consumentenomgeving onze vook keur.

Het gebrek aan uniformiteit en het ontbreken van een nadere concretisering en operationalisatie van de belevingsdimensie hebben er ons inziens toe bijgedragen dat de betreffende modellen nog naw weliks toegepast zijn en dat de brukbaarheid er van in het kader van het segmenteren, beschrijven en montoren van relaties met klanten nog nauwelijks is aangetoond.

Aan deze lekorkoming willen wij tegemoetkomen door de introductie van de Relatieperceptie en Loyaliteit Matrix' (korweg: het RLM-moded), weergegeven in figuu' 4.6 .

De belevingsdimensio word invulling gegeven door de perceptie van de anemer betreffende de celutic met de anbieder. De relatieperceptie wordt verder geconcretiseerd middels de variabele "retationship commiment" (RC), oftewel relatiesterkte; de mate van binding tussen afnemer en aubieder, foais gepercipiend door de anemer. Relatiesterkte word gemeten met behulp van de $\mathbb{R C Q}$.

De gedragsdmensic word invalling gegeven door de feiteljke lovaliteit van de afnemer aan de aubicder. Loyaliteit wordt hier dus gebnikt in har meest traditionele betekenis, namelijk die van reitelijk (koop)gedrag (Strandvik en Liljander, 1994b). Het betreft aspecten van (historisch) koopgedrag en communicatie tussen afnemer en aanbieder, zoals: frequentie, regelmaat, duur, bredtlo van het agenomen assortiment, recentheid, geldelijke waarde, communicatievormen, etcetera. 


\section{Relatie wordt gekenmerkt door:}

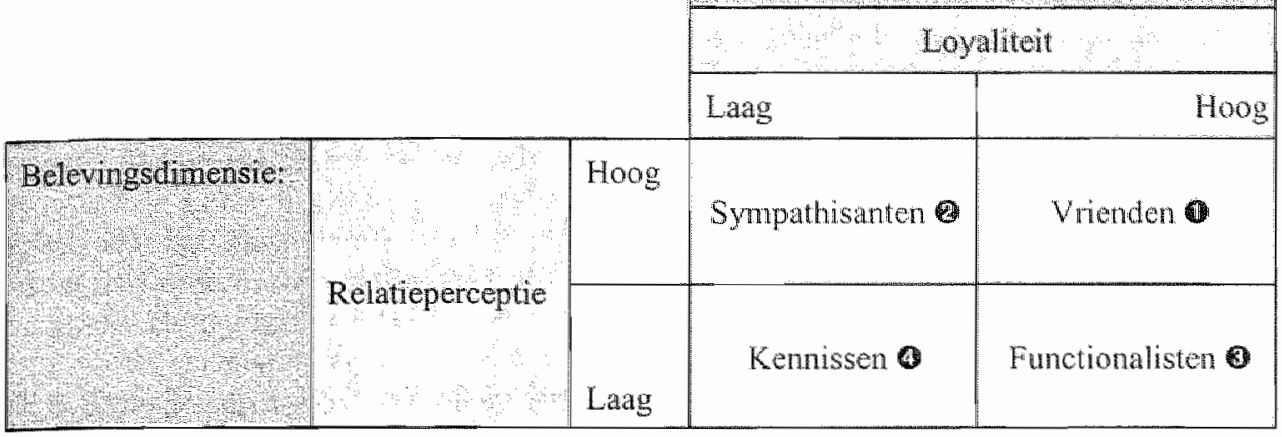

Figuur 4.6 De Relatieperceptie en Loyaliteit Matrix

Op basis van de scores op beide dimensies kan de klant aan cen cluster in deze $2 \times 2$ matrix worden toegewezen. Voor de duidelijkheid is elk van de vier groepen een bepalde naam ter identificatie gegeven, naar het voorbeeld van Krapfel et al. (1991).

Frienden zijn loyaal aan de organisatie in die zin dat zij een relatief belangrijk deel van de winst en/of omzet van de organisatie voor hun rekening nemen via regetmatige herhalingsaankopen. Zij zijn derhalve van grote economische waarde voot de organisatie. Daamaast percipiëren zij een sterke relatie.

Sympathisanten ervaren net als vrienden een sterke binding met de aanbieder, maar brengen dat zelf (nog) niet tot uitdrukking in hun koopgedrag: zij zijn (momenteel) van geringe economische waarde voor de orgarnisatie.

Functionalisten nemen een belangrijk deel van de omzet voor hun rekening en zijn in dat opzicht "functioneel" in het bereiken van de economische 'targets' van de organisatic. Zij ondervinden echter geen bijzondere band met de organisatie. Die band is dan ook wrij kwetsbaar.

Kenmissen percipiëren noch een sterke relatie, noch zijn zij (monnented) van grote economische waarde voor de organisatie. Dit kan enerzijds kenmerkend zijn voor de opbouw van een nieuwe relatie, anderzijds voor het ten einde lopen van een reeds langer bestaande relatie (Dwyer et al., 1987).

Elk van deze klantengroepen vraagt on een eigen specifieke (relatie)marketingbenadering. Eun benadering die niet alleen gebaseerd is op de huidige economische wathe en de huidige relatiestierkte, maar ook op potentiele mogelijkheden de relatie verder te versterken en in economisch opzicht te verbeteren (of af te bouwen, indien nodig en gewenst). Om inzicht the krijgen in de mogelijkheid de relatie te versterken kan per klantengroep onderzoch worden wat de discrepantie is tussen de relatie zoals die momenteel ervaren wordt en zoals die gewenst. wordt. Tenendo inzicht te krijgen in toekomstige omzetmogelikheden bij de klant kan gekeken worden nar het aandeel dat de aanbieder momenteel heeft in de bestedingen van de klant ("customer share" of "share of wallet'). 


\section{Specifieke kenmerken wan het RLM-model}

De specifeke kermerken wan het RLM-model hebben betrekking op de volgende punten:

- het model omvat zowel aen gedragsdimensie als een belevingsdimensie. Deze dimensies ziln nader geconcretiseerd teneinde de theorie operationaliseerbaar te maken voor het marketingbeleid;

- Ge gedragsdimensie wordt nader geconcretiseerd door de feitelijke loyaliteit, het koopgedrag var de afnemer, en vertegenwoordigt de economische waarde wan de klantrelatie voor de aanbicder. $Z \mathrm{ij}$ wordi gemeten via koopgedragvariabelen;

- de belevingsdimensie geeft primair de attitude van de klant ten aanzien van de relatie met de aanbieder weer. Deze attitude word door de variabele relationship commitment (RC) nader geconcretiseerd an door de door ons naar woren gebrachte RCQ gemeten;

- het meter van RC vindt plaats bij, en vanuit het gezichtspunt van, de afnemer.

Herdoor wordt het model meetbaar en in de praktijk toepasbaar, in tegenstelling tot het merendeel van de eerder besproken modellen. Deze laatste worden in de literatuur namelijk veeler als conceptuele modellen gepresenteerd. Meting van relatiesterkte vindt daarbij slechts summier plaats: alleen Wilson en Strandvik en Liljander hebben, woor zover ons bekend, in de prakijk geexperimenteerd met het meten van relatiesterkte als invulling van de belevingsdimensie. Nog sporadischer worden in de literatuur aan de modellen strategische beleidsimplicaties verbonden.

Wij zullen ons wat het RLM-madel betreft niet beperken tot de conceptuele weergawe, maar wij zullen het model ook empirisch toetsen. Daamaast zullen wij aan de resultaten strategisehe beleidsimplicaties verbinden. Het RLM-model is er namelijk op gericht:

1. groepen van homogene eindgebruikers te identificeren (homogeen in termen van relatieperceptie en koopgedrag);

2. strategieën en beleidsmaatregelen te adviseren, afgestemd op elk van deze groepen (van homogene eindgebruikers); en,

3. de voor elke groep geadviseerde strategieèn en beleidsmaatregelen aan te passen aan de specilieke omstandigheden van elke individuele eindgebruiker bimnen de groep (onder andere op basis van bijvoorbeeld het procentuele aandeel in de aankopen en de kloof tussen huidige en gewenste relatie).

Op basis van de hier genoende specilieke kenmerken onderscheidt het RLM-model zich van de eerder besproken modelten en word, met name met betrekking to de belevingsdimensie (met behulp van RC en har meetschaal, de RCQ), een belangrijke bijdrage geleverd aan het segmezteren, beschrijven en monitoren van relaties met klanten.

Dat een model als het RLM-model bruikbaar is om het klantenbestand in te delen in groepen met individuele klanten wordt door Koopmans en Jochems (1997) verder onderbouwd. Zij stellen namelijk dat een bruikbare indeling is gebaseerd op minsters twce aspecten: een interne, bedrijseconomische factor en een externe, klantenfactor.

Als inteme, bedrijfseconomische toetssteen stellen zij het rendement per individuele klant woor. Bedrijven beschikken echter niet altijd over de noodzakelijke gegevens om het rendement per individuele klant te kunnen vaststellen, bijvoorbeeld omdat hun accountingsystemen daarop niet zijn ingericht. In ons RLM-model wordt de interne, bedrijfseconomische factor daarom vertegenwoordigd door het koopgedrag (loyaliteit) van de klant, als belangnijke factor die het rendement per klant mede bepaalt. 
Als externe, klantvariabele geven Koopmans en Jochems (1997) de voorkeur aan merktrouw per individuele klant. Merktroww is daarbij opgebouwd uit twee componenten: 1] concreet bestedingsgedrag oftewel 'share of wallet', geoperationaliseerd door het bepalen wan het aandeel van het budget voor een produktcategorie dat cen klant besteedt aan een specifiek merkartikel, en 2] de merkattitude van de klant ten opzichte van het merkartikel. In ons RLMmodel neemt $\mathrm{RC}$ de plaats in wan de merkattitude, terwijl het klantaandeel in ons onderzoek zal worden meegenomen om inzicht te krijgen in toekomstige omzetmogelijkheden bij de klant. Kortom: de factoren die Koopmans en Jochems $(1996 ; 1997)$ wan belang achien om tot een bruikbare klantenindeling te komen zijn in het RLM-nodel vertegenwoordigd. Met bruikbaar wordt dan bedoeld dat er groepen klanten ontstaan waarbij elke groep zich kenmerki door een specifieke combinatie van de interne, bedrijfseconomische factor en de externe klanlenfactor.

Het RLM-model is gebaseerd op de veronderstelling dat gedrag en beleving in verschillende mate kunnen reageren op eenzelfde marketingactiviteit. Zoals reeds eerder vermeld werd, suggereerden Denize en Young (1996) dat de attitudecomponent en de gedragscomponent verschillende dimensies in een relatie vertegenwoordigen. Dowling en Uncles (1997, p. 73) geven daarnaast aan dat "many or most heavy users are multibrand loyal for a wide range of products and services. That is, a company's most profitable customers will probably be the competitors" most profitable customers as well." Daarmee geven zij aan dat klanten met een meer dan gemiddeld koopgedragpatroon nog geen sterke binding met een specifieke aanbieder hoeven te hebben. Het is met andere woorden niet zonder meer juist, te veronderstellen dat een sirategie die gericht is op het versterken van de relatie (relatieversterking) per definitie ook leidt tot een verbeterd koopgedrag. Omgekeerd zal een strategie die gericht is op het verbeteren wan het koopgedrag van de klant (klantontwikkeling) niet per definitie leiden tot een hogere mate van binding. De binnen het vakgebied marketing veelal gehanteerde assumptie dat een hoge mate van loyaliteit automatisch een sterke relatie impliceert, zal derhalve middels de volgende hypothese expliciet getoetst en kritisch geëvalueerd worden.

Hypothese 2 Het koopgedrag (de loyaliteit) van een klant is eenduidig positief gerelateerd aan de sterkte van de relatie met de aanbieder zoals door de klant gepercipiecrd.

Deze hypothese impliceert dat we het verband tussen loyaliteit en relatiesterkte expliciet dienen te toetsen. Op basis van het voorgaande betoog verwachten we dat er onvoldoende basis zal zijn om deze hypothese statistisch te onderbouwen en dat we de hypothese dienen te verwerpen". Het verwerpen van de hypothese impliceert dat het managen van relaties niet alleen gebasecrd kan worden op koopgedraggegevens, maar dat bij het managen van relaties beide dimensies van een relatie, gedrag èn beleving, in beschouwing genomen dienen te worden.

"Hypothese 2 geeft idealiter aan dat er in slechts twee kwadranten wamenningen zullon zijn (kemnissen en vrienden). Dit betwijelen wij. Echter een hypothese als: "Het koopgedrag van ten klant is niet eenduidig gerelateerd aan de sterkte van de relatie met de anbieder zoals door de klant gepercipieerd', of: 'Een goede (loyale) klant is njet identiek aan een klant die een sterke relaic percipieert" is zelfs zonder statistisch te toelsen altijd te verwerpen, omdat er sprake is van oxerlap. Met andere woorden: in een aantal gevallen zal een goede (loyale) klant dezelfde zijin als hij die een sterke relatie percipicert. Vandaar dat ervoor gekozen is de hypothese te fomuleren overeenkomstig hypothese 2 met de verwachting deze ook op statistische gronden te kunnen verwerpen. 


\subsection{HET VERILLAREN VAN RELATIESTERKTE: EEN MODEL}

Indien relatiesterkte op een valide en betrouwbare wijze gemeten wordt, is het mogelijk, bij herhaald toepassen van het meetinstrument, wijzigingen in relatiesterkte vast te stellen en te evalueren. Door relatiesterkte wervolgens als de te verklaren variabele te beschouwen, wordt een beter inzicht verkregen in factoren die voor relatiesterkte in het algemeen, en voor de wijziging daarin in het bijzonder, verantwoordelijk zijn. In deze paragraaf zal worden gekeken naar welke factoren van invloed zijn op relatiesterkte. Daarmee zijn toekomstige relaticversterkende activiteiten en beoogde ontwikkelingsrichtingen van de relatie beter te verantwoorden. Op basis van een literatururstudie zal een voorstel gedaan worden voor een dergelijk model. Het empirisch onderzoek zal dan meer inzicht moeten verschaffen in hoe een relatie zich, bijvoorbeeld in de loop van de tijd, ontwikkelt, zowel qua sterkte als qua variabelen die hun invloed doen gelden. Het doel dat daarmee word nagestreefd is managers en wetenschappers meer houvast te verlenen bij het nemen van beslissingen, het uitvoeren van marketingactiviteiten en het verrichten van onderzoek, die gericht zijn op het versterken van de relatie (beinnvloeden van $\mathrm{RC}$ ).

In de literatuur worden talrijke variabelen genoemd, die in een relatie van belang kunnen zijn. Uit die variabelen is een selectie gemaakt, op basis van wat in de literatuur veelvuldig aangeduid wordt als zijnde kritieke factoren in de ontwikkeling van relaties. Eerst zal het selectieproces kort toegelicht worden (\$4.4.1). Vervolgens zullen de voor het empirische onderzoek geselecteerde variabelen nader besproken worden en in een model worden ondergebracht (\$4.4.2).

\subsubsection{SELECTIEPROCES: DE PROCEDURE}

De eerste stap van het selectieproces bestond uit het bestuderen van literatuur op de gebieden van business-to-business (b-to-b) marketing, consumentenmarketing en dienstenmarketing. Het merendeel van de literatuur op het gebied van relatiemarketing heeft betrekking op 'buyerseller' relaties, oftewel verticale relaties in de industriële (b-to-b) omgeving ${ }^{7}$. Het bestuderen van deze $b$-to-b literatuur resulteerde in vier variabelen die door ons aok mogelijkerwijs van toepassing geacht worden in business-to-consumer relaties. Het betreft de variabelen: tevredenheid, vertrouwen, gepercipieerde overstapkosten en betrokkenheid. Betrokkenheid zal in het viteindelijke model echter niet apart als onafhankelijke variabele worden opgenomen omdat betrokkenheid al deel uitmaakt van (onze definitie van) relationship commitment. Dit blijkt ook uit de in $\$ 4.2 .2$ genoemde drie kenmerken van commitment (1. een sterk geloof in en acceptatie van de doelen en waarcen wan de organisatie; 2 . de bereidheid om zich in te spannen voor de organisatie; en 3 . een sterk verlangen om deel te blijven uitmaken van de organisatie) die de aanwezigheid van een bepaalde mate van betrokkenheid impliceren. Voor het vervolg van onze selectie wordt woor de verklaring van relatiesterkte dan ook uitgegaan van de volgende variabelen: tevredenheid, vertrouwen en gepercipieerde overstapkosten.

Als voomaamste bron op het gebied van consumentenmarketing kwamen de publicaties van Peelen $(1989 \mathrm{a} ; 1989 \mathrm{~b})$ naar voren. Hij verklaart de sterkte van de relatie door middel van vier variabelen: tevredenheid, attractiviteit, overstapkosten en toekomstverwachting. Daarbij baseert hij zich op een studie van zowel de b-to-b marketingliteratuur als de sociale ruiltheorie. Met de

${ }^{7}$ Bijvoorbeld: Anderson en Weitz, 1989; Anderson en Narus, 1990; Ganesan, 1994; Magrath en Hardy, 1994; Morgan en lfuni, 1994: Wilson, 1990: 1995. 
variabele toekomstwerwaching wordt aangegeven of de consument daadwerkelijk de intentie heeft de relatie voort te zetten (Peelen, 1990b). Als zodanig is het een gedragsintentie dio overeenkomt met het derde kenmerk van relationship commitment: de wens deel te blijven uitmaken (lees: Klant te blijven) van de organisatie en dus de relatie te continueren. Deze gedragsintentie is een component van commitment (Porter et al., 1974). Bovendicn meet de variabele toekomstwerwachting in feite de betrokkenheid van de afnemer bij de aanbieder (Hoekstra, 1998). Ten aanzien van betrokkenheid van de afnemer bij de anbieder is eender reeds opgemerkt dat dit als een kenmerk van binding word beschowwd en dar deel van uitmaakt. De variabele toekomstverwachting wordt door ons om genoende redenen dan ook niet meegenomen in het aiteindelijke model. Aan de eerder geselecteende variabelen tevredenheid, vertrouwen en gepercipieerde overstapkosten kan naar aanleiding van de studie van Peelen de variabele attractiviteit worden toegevoegd.

In empirisch onderzoek naar relaties zijn deze variabelen (tevredenheid, vertrouwen, gepercipieerde overstapkosten en attractiviteit) regelmatig meegenomen en is de rol wan deze variabelen bij het opbouwen en onderhouden van de relatie nader onderzocht en bevestigd. Crosby et al. (1990) bijvoorbeeld richtten zich op relaties tussen agenten voor levensverzekeringen en polishouders. Daarbij definieren zij de kwaliteit van de relatie in temen van vertrouwen en tevredenheid. Vertrouwen en tevredenheid (relationship quality) bleken een significante invloed te hebben op de verwachting bij de klant om ook in de toekomst zaken met de agent te blijven doen. Deze verwachting is in onze optiek, zoals eerder acangeduid, een wezenlijk kenmerk van relationship commitment. Jackson $(1985 ; 1986)$ toonde het belang aan van overstapkosten in b-to-b relaties. Morgan en Hunt (1994) toonden in een studie naar 'buyerseller' relaties aan dat zowel overstapkosten als vertrouwen positief van invloed zijn op relationship commitment. Geyskens en Steenkamp (1995) stellen eveneens dat vertrouwen positief van invloed is op commitment. Net als bij Morgan en Hunt (1994) had hun onderzoek betrekking op 'buyer-seller' rellaties, en wel tussen autodealers en hun leveranciers. Kelley en Davis (1994) stelden een positief verband vast tussen tevredenheid en commitment waar het relaties betrof tussen een dienstverlener (gezondheidsclub) en zijn (particuliere) leden.

Zoals blijkt betreft het empirisch onderzoek op het gebied van b-to-b relaties of relaties in de dienstverlening. In hoeverte deze verbanden ook in geval van relaties tussen anbieders van "fast moving consumer goods" (fmcg"s) en hun eindafnemers significant zijn, is volgens ons (nog) niet of nauwelijks onderzocht.

Uiteindelijk zijn de volgende variabelen op basis van dit overzicht in hel model opgenomen: attractiviteit, gepercipieerde overstapkosten, vertrouwen en tevredenheid als onafhankelijke variabelen en relatiesterkte als afhankelijke variabele. De studies waaruit zij afkomstig zijn hebben aangetoond dat zij relevant zijn. Wij zullen ze nu toepassen op de fmcg sector en onderzoeken of dit relewant en verantwoord is. De geselecteerde vier variabelen werden in aantal voldoende geacht voor de verklaring van relatiesterkte.

Onderzoekers krijgen te maken met de "tradewoff" tussen enerzijds cen moclel dat zo volledig mogelijk is teneinde als onderzoeker de complexiteit wan het fenomeen aan te duiden en anderzijds een model dat praktisch nog bruikbaar is. A.ts praktische vuistregel wordt door Anderson en Narus (1990) aanbewolen niet meer dan vijf of zes constructen in een model op te nemen. Het mode] dat hier door ons gepresenteerd word voldoet daaraan. 


\subsubsection{GESELECTEERDE VARABELEN}

Atruaturiteit

Atractiviteit is de mate warin de ancmer de relatie met de huidige aanbieder prefereert boven alternateve relaties. De attractiviteit van en bestaande relatie wordt bepaald door de bestaande relatie te vergeliken met andere (altematieve) relaties (Peelen, 1989b; Storm, 1991). De consument vergelijkt de bestaande relatie met alternatieve relaties op basis van voomamelijk fysieke, tastbare, c.q. objectieve aspecten (zoals samenstelling van het assortiment, locatie, verkriggharherd van produkten/diensten, en dergelijke). De Ruyter et al. (1997) stellen bijvoorbeeld dan de houding van de klant ten aanzien van het assortiment van de aanbieder van inwloed kan zijn op relationship commiment. Zij constateerden namelijk dat cliënten van accountants een uitgebreide serviceportfolio warderen. Hoewel cliënten van accountants niet altijd gebruik maken van alle diensten, geeft het cliënten het idee van deskundigheid waar zij. indien nodig, gebruk van kunnen maken. Vanuit dat oogpunt werd een positief verband angetrofen tussen dienstenportfolio en commitment. Echter, sommige clienten waren ook van mening dat investeren in (uitbreiding van) het dienstenassortiment wel eens tot tariefserhoging zow kumnen leiden. Op basis van het vergelijken van aanbieders op dit soort aspecten vormt de consument zich een beeld van de relatieve sterkte van de propositie van de huidige aanbieder. Met andere woorden: hij bepaalt de relatieve positie wan zijn huidige aanbieder ten opzichte van concurrerende aambieders. Het vergelijken van de huidige relatie met alternatieve relaties resulteent in een beste altematief voor de huidige relatie. Nammate de propositie van het beste altematief lager is dan die van de huidige relatie, zal de consument minder bereid zijn zijn huidige relatie te verbreken. Morgan en Hunt (1994), die woor attractiviteit de term "relationship benefits' gebruiken, yonden en posilief verband ussen attractiviteit en relationship commitnent in het geval van een specifieke 'buyer-seller' relatie (de relatie tussen onafhankelijke autobandenretailers en hun leverancier): afnemers zijn bereid zich aan een aanbieder te binden indien deze superieure voordelen biedt. Peelen (1989b) werwachtte eveneens dat de binding met een aambieder positief beinvloed zou worden indien de relatie met die aanbieder aantrekkeliker is dan relaties met alternatieve aanbieders. Hij trof echter geen eenduidig positief werband aan tussen attractiviteit en binding waar het relaties betrof tussen ananbieders ats do ANWB, een creditcard maatschappij en een boekenclub energijds en consumenten andorzijds. In de context van relaties tussen anbieders en eindafnemers van fincg's is cen positief verband lussen atlractiviteit en binding niet eerder angetoond. Ook in die context verwachten wij echter dat de attractiviteit van een aanbieder ertoe bijdraagt dat de consument cen sterkere relatie met de aanbieder percipieert. Daartoe is de volgende hypothese opgesteld:

Hypothese 3.1 Hoe groter de attractiviteit voor de consument van en relatie met en aanbieder, hoe groter de sterkte van de relatie (mate van binding) met die atanbieder.

\section{Onerstaphosten}

Overstapkosten kumnen en drempel vormen on de relatie te beëindigen (Dwyer et al, 1987; Poiesz en Van Raaij, 1993; Morgan en Hunt, 1994). Overstapkosten bestaan uit (Jackson, 1985; 1986; Pecten. 1989b): 
- inspanning en tijd die het owerstappen vergt, bijvoorbeeld als gevolg van ontbindingsprocedures, het doorbreken van gewoonten, het vergaren wan informatio om een keuze uit de altematieven te maken en het afshiten wan de koop;

- geld dat gemoeid is met overstappen, bijvoorbeeld entreegelden of contributiegelden die moeten worden betaald om aan een relatiemarketingprogramma te kunnen deelnemen, investeringen die in personeel en materieel van de aanbieder gedaan moeten worden om deze in stat te stellen het gewenste produkt te leveren; en,

- het risico dat de neuwe aanbieder zijn beloften niet nakomt, bijvoorbeeld: door gebrek aan ervaring met de nieuwe aanbieder kan een verkeerde inschating worden gemaakt van de verwachte uitkomsten bij de alternatieve aanbieder.

Het vermijden van dit soort overstapkosten sluit aan bij de persoonlijke behoeften van mensen om relationeel marktgedrag te vertonen (Sheth en Parvatiyar, 1995):

- behoefte om complexe koop- en consumptiesituaties te vereenvoudigen en meer efficiency in de besluitvorming te bereiken (van 'extended' en 'limited probtem solving" naar "routinized response behaviour");

- behoefte om het informatieverwerkingsproces te vereenwoudigen;

- behoefte om gepercipieerde risico"s verbonden an toekomstige beslissingen te vermijden; en,

- behoefte om cognitieve consistentie te handhaven en zich psychisch confortabel te voelen, op het genak te voelen.

Tevens blijkt uit het bovenstaande dat overstapkosten ook niet-financiee. van aard kumnen zijn. Niet-linancielle kosten, zoals het werlies aan (sociale) tevredenheid die ontleend wordt aan de sociale binding, hebben hun weerslag op de sterkte van de relatie. Met name in consumentenmarkten kunnen deze niet-financiële kosten van invloed zijn op de sterkte van relaties. Voomamelijk sociale en institutionele factoren (Sheth en Parvatiyar, 1995) zijn veelal niet-financieel van aard. Sociale motieven waarom een consument een band met een aanbieder aangaat, komen voort uit:

- de invloed van gezin en sociale groepen en hum gedragsnormen; en,

- invloed van referentiegroepen en mond-tot-mond communicatie.

Institutionele factoren die de binding beïnvloeden komen voort uit:

- regetgeving door de overheid;

- religie;

- invloed van werkgever; en,

- marketing beleid van organisaties.

Saciale en institutionele factoren leiden ertoe dat consumenten hun keuzen bewust beperken en zich conformeren aan gedrag dat "social wenselijk" geacht wordt. Datmee vemijden zij tot op zekere hoogte conflictsituaties. Indien consumenten trachten het maken van overstapkosten te vermijden, om financièle en/of niet-fnancièle redenen, dan "it reflects some sort of commitment made by the consumer to continue patronizing the particular marketer despite numerous choices that exist for him or her" (Sheth en Parvatiyar, 1995, p. 256). Indien mei de transactie grote investeringen gemoeid zijn (zowel financieel als niet-financieel) of indien er sprake is van complexe dienstverlening zal de consument dus meer geneigd zijn lot het onderhouden van een relahie met éen aanbieder of een beperkt aantal aambiedars in plaats van telkens of regelmatig naar een andere ambieder over te stappen. Als woorbeelden kunnen genoend worden: fuanciele dienstwerlening (o.a. hypotheken); medische of juridische dienstverlening (Zeithaml en Bitner, 1996; Christy et al., 1996). Ook Dwyer el al. (1987, p. 14) 
stellen dat "the buyer's anicipation of high switching costs gives rise to the buyer"s interest in maintaning a quality relationship". Hieruit blikt tevens dat het gaat on de perceptie van de overstapkosten, hetgeen met natme bij niet-financiele overstapkosten van belang is. Peelen (1989b) kon, net als bi attractiviteit, geen eenduidig positief verband aantonen tussen overstapkosten en binding waar het relaties betrof tussen aanbieders als de ANWB, een creditcard matschappij en een boekenclub enerzijds en consumenten anderzijds. Het verband tussen overstapkosten en commitment is met name in b-to-b situaties onderzocht (o.a.: Dwyer et al, 1987, Wilson, 1990; Morgan en Hunt, 1994). Daanuit bleelk een positief verband te bestaan tussen gepercipieerde overstapkosten en commitment: gepercipieerde of verwachte overstapkosten genereren commitment. Gelet op deze laatste resultaten wordt de volgende hypothese opgesteld:

Hypothese 3.2 De relatie is sterker naamate de consument hogere overstapkosten percipicent.

\section{Vertrouwen}

Vertrouwen blijkt éen van de meest fundamentele aspecten in een relatie te zijn'. Spekman (1988) stelt onomwonden dat vertrouwen de hoeksteen van het strategisch partnership is. Volgens Steenkamp (1991) is het moeilijk, zo niet onmogelijk, om een langdurige relatie op te bouwen zonder dat er vertrouwen tussen de partners bestaat. Vertrouwen is én van de meest voorkomende variabelen in relatie-modellen. Morgan en Hunt (1994) zien vertrouwen als sleuteivariabele ( Key Mediating Variable") in elk van de tien relatietypen die zij onderscheiden (zie figuur 2.1), dus ook in relaties tussen consumenten en een organisatie. "Customer"company relationships require trust, not unlike other types of relationships" stellen Berry en Parasuraman (1991, p. 144).

Anderson en Narus (1986, p. 326;1990, p. 45) omschrijven vertrouwen als "the firm"s belief" that another company will perform actions that will result in positive outcomes for the firm, as well as not take unexpected actions that would result in negative outcomes for the firm". Volgens Wilson (1990) is vertrouwen in een partner het geloof van de ene partij dat de andere partij zal handelen in het belang van de ene partij. Crosby et al. (1990, p. 70) stellen dat vertrouwen gedefinieerd kan worden als "a confident belief that the salesperson can be relied upon to behave in such a manner that the long-tem interest of the customer will be served." Dwyer et al. (1987) omschrijven vertrouwen alls het geloof dat de beloften van de ene partij betrouwbaar zijn en dat deze partij aan haar verplichtingen zal voldoen. Poiesz en Van Raaij (1993) stellen dat vertrouwen to maken heef met hoe consistent en positief de ene partij verwach, dat de andere partij zal handelen. $Z_{i j}$ maken daarbij een onderscheid tussen vertrouwen in enge zin en vertrouwen in brede zin. Vertrouwen in enge zin wordt gebruikt als de ene partij verwacht dat de andere partij zich zal gedragen zoals afgesproken is, of volgens algemeen aanvarde nomen verwach mag worden. De hierboven vermelde definitie van Dwyer et al. kan als een definitie van vertrouwen in enge zin gezien worden. Vertrouwen in brede zin is het geloof zonder wwijel dat de belangen en activiteiten van de andere partij niet conflicteren met de eigen belangen en activiteiten, zelfs zonder expliciete afspraken (blind"

\footnotetext{
"Schurr en Ozanne, 1985; Swan et al., 1985; Dwyer et al., 1987; Anderson en Weitz, 1989; Anderson en Narus, 1990; Crosby et al. 1990; Steenkamp, 1991; Webster, 1992; Poiesz en Van Raaij, 1993; Ganesan, 1994; Morgan en Hunt, 1994: Wilson, 1990 en 1995; Geyskens en Steenkanm, 1995 en 1997.
} 
kunnen vertrouwen). De eerder vermelde definitie van Crosby of al. kan gezien worden as gent omschrijving van vertrouwen in brede zin. Steenkamp (1991, p. 69) omschrift vertrowwen in de leverancier als "de verwachting van de afnemer dat de tockomstige acties van de leverancier positieve gevolgen hebben voor de afnemer". Vertrouwen is dus sterk toekomstgencht. gebascerd op ervaringen in het verleden.

In 'buyer-seller' relaties is het belang van vertrouwen en de positieve invloed van vertrouwen op commiment veelvuldig angehaald en aangetoond ${ }^{10}$. Dwyer et al. (1987) wijzen er op dat de graad van vertrouwen hel al dan niet succeswol zijn van relaties in belangrijke mate verkatat. Vertrouwen in een partner geeft een gevoel van zekerheid en vemindert do onzekertheid omtrent de vraag of de juiste partnerkeuze gemaakt is. In situaties warm sprake is van wen groot wederzijds vertrouwen zal de communicatio opener zijn en zullen vookomende problemen, die tot conflictsituaties kunnen leiden, niet verzwegen worden, maar relatef constructief en doorgaans op vriendschappelijke voet worden opgelost (Morgan en Hunt, 1994; Geyskens en Steenkamp, 1997). Dit heeft een positieve uitwerking op de sterkte en de dum van de relatie. Relaties die gekenmerkt worden door een hoge mate van vertrouwen worden zodanig gewaardeerd dat de participanten een grotere binding aandurven. Omdat commitment ook een zekere mate wan kwetsbaarheid impliceert, geven participanten de voorkeur aan partners die ze kunnen vertrouwer. Omgekeerd kan wantrouwen bij de ene relatiepartner leiden tot wantrouwen bij de andere relatiepartner, aanleiding geven tot opportunisme en de relatie aantasten (Morgan en Hunt, 1994).

Zeker ook in de dienstensector zal het weinig grijpbare karakter van diensten ertoe leiden dat vertrouwen in de dienstverlener bepalend is voor de mate van binding met die dienstverlener (Geyskens en Steenkamp, 1997). Met name in de financiële dienstvertening, maar ook in artspatiènt relaties, is de rol van vertrouwen bij het opbouwen van een sterke relatie essentieel.

Vertrouwen wordt dan ook als een belangrijke determinant van relationship commitment gezien (Wilson, 1990; Achrol, 1991; Mooman et al., 1992; Morgan en Hunt., 1994).

In relaties tussen aambieders en eindgebruikers van fmeg"s is een dergelijke positieve invloed van vertrouwen op commitment nog niet empiriseh angetoond. Het is echter te verwachten dat een positieve invloed van vertrouwen op commitment niet beperkt bliff tot 'Buyer-Seller' relaties, maar, gelet op het voorgaande, ook op gaat voor relaties tussen aanbieders en consumenten van fmcg's. Daarom zal de volgende hypothese expliciet getoetst worden:

Hypothese 3.3 Hoe groter het vertrouwen in de arbieder, hoe sterker de retatio met die aanbieder.

\section{Tevredentheid}

Tevredenheid van consumenten wordt bepaald door de vergelijking tussen verwachte en werkelijke uitkomsten". De verwachtingen ten aanzien van de uitkomsten uit ruil worden met name bepaald door eigen ervaringen en ervaringen varn anderen, alsmede een inschatting van toekomstige uitkomsten (bijwoorbeeld op basis van informatie uit promotie). De vergelijking

'Zue onder meer: Dwyer et al., 1987; Anderson en Weitz, 1989; Anderson en Narus, 1990; Moorman. et al., 1992; Ganesan, 1994; Morgan en Hunt, 1994; Geyskens en Steenkamp, 1995.

"Zie bijwoorbeeld: Dwyer el al., 1987; Crosby et al, 1990; Wilson, 1990; Steenkamp, 1991; Storm, 1991 ; Poiesz en Van Raai, 1993; Hockstra, 1998; Bhemel en Eggert, 1998. 
Iussen de verwachtingen ten aanzien van de untkomsten uit ruil en de daadwerkelike utikonsten resulteert in tevedenheid.

Crosby en Stephens (1987) vonden dat bij dienstvertenende organisaties klanttevredenheid postivef van invloed was op klantbehoud. Een positieve invloed van klanttevredenheid op klantloyaliteit werd gevonden door Fomell (1992), alsmede Bloemer (1993a) die daarbij tevens aangeeft dat het geen éér-op-éen relatie betreft. Klantbehoud en klantloyaliteit zijn belangrijke kennerken vath RC (Kelley en Davis, 1994). Ook de organisatieliteramur duidt op een positief verband tussen tevredenheid en organizational commitment (Mathieu en Zajac, 1990). In het algemeen zou dan ook gesteld kumen worden: hoe groter de tevredenheid, hoe groter de binding (Hoekstra, 1998 , Kelley en Davis, 1994).

Echter, een antal auteurs betwijfelt de inwloed van klanttevredenheid op de mate van binding (Henning, 1996, Stauss en Neuhaus, 1996\%, Empirisch onderzoek toont veelal slechts een zwak. verband tussen klantevredenheid en de intentie to herhalingsaankopen, en dus de bereidheid de relavic te continueren (LaBarbera en Mazursky, 1983; Sandwik et al, 1997). Een verklaring hierwoor kan zijn dat tevedenheid mel name betrekking heeft op ervaringen uit het verleden, terwij RC ook een op de toekomst georiënteerde component bevat. Tevredenheid vindt een toekomstgerichte aanvulhing in vertrouwen (Diller, 1997c). Tevredenheid wordt samen met vertrouwen als relatiekwaliteit gedefinterd (Crosby el al., 1990; Lagace et al., 1991; Wray et al., 1994). Er mag dan ook een positief kerband verondersteld worden tussen tevredenheid en vertrouwcn. Wilson (1990) en Steenkamp (1991) bijvoorbeeld stellen dat tevredenheid bijdraagt aan een groter vertrouwen in de beverancier en aan de versteviging van sociale relaties. Tevredenheid met de relatie reflectect een posinieve beleving gebaseerd op de resultaten die in het verleden zijn voortgevloeid uit de relatie (Diller, 1997c). Dergelijke resultaten bevorderen het vertrouwen in die zin dat de betrokken partijen elkaar niet zullen beconcurreren, maar zullen coöperewen en geen acties zullen ondememen ten nadele van de partner. In het tegenovergestelde geval leidt ontevredenheid met de resultaten van een relatie tof wantrouwen en argwaan bij het voortzetten van de relatie (Ganesan, 1994). Tevredenheid met de witkonsten wit de relatie in het verleden biedt de afinemers een gevoel van zekerheid met betrekking tot de toekomstige uitkomsten uit de relatie. Met andere woorden: de afnemer heef op basis van ervaringen met de aambieder in het verleden vertrowwen in de aanbieder met betrekkng tot de lockomst van de relatie en is bereid in de toekomst van de ratate te investeren (Geyskens en Steenkamp, 1997). Het vertrouwen groeit als de uitkomsten uit ruil keer op keer minimaal aan de verwachtingen voldoen (Peelen, 1989b; Diller, 1997\%; Bhemel en Eggert, 1998). Tovredenhed is aldus gebaseerd op ervaringen uit het verleden en beinvloedt het vertrouwen, dat gericht is op de lockomst. Om die reden word tevredenheid in het model opgenomen als anleceden van vertrouwen. Tevredenheid heef dus via vertrouwen invloed op RC, terwijl vertrouwen rechtstrecks vam invloed is op RC. Hieruit resulteert de volgende hypothese:

Hypothese 3.4 Er bestat een positief verband tussen tevredenheid over de relatie met een aambieder on het vertuwen in die anbieder.

Op momenten dat een klant ontevreden is met de uitkonsten uil de huidige relatie, bestaat er een kans dat deze klant incidenteel de uitkomsten uit de bestaande relatie vergelijkt met die uit altematieve relaties. Dit impliceert echter geenszins dai tevredenheid met de uitkomsten uit de huidige relatie positief van invloed is op de attractiviteit van de bestaande relatie. Het is immers niet zo dat alle witkomsten uit de huidige relatie zonder meer en daadwerkelijk vergeleken 
worden met de uitkomsten uit altematieve relaties (Peelen, 1989b). Daamaast betekent ontevredenheid met de uitkomsten wit de huidige relatie niet dat alternatieve relaties daardoor aantrekkelijker worden voor de klant: ondanks een moment van ontevredentheid kan de hüdige relatie attractiever blijven dan alternatieve rellaties. Dit hangt tevens samen met het gegeven dat de attractiviteit van de huidige relatie mede bepaald wordt door activiteiten van de altenatieve aanbieders. Attractiviteit is een concurrentievariabele of positioneringsvariabele: het geef de relatieve positie weer van de bestaznde relatie ten opzichte van altematieve relaties.

Evermin zal tevredenheid invloed uitoefenen op de overstapkosten. Op momenten dat een klant ontevreden is met de uitkomsten uit de huidige relatie, is de kans groter dat deze klant een inventarisatie maakt van de overstapkosten. Echter de hoogte wan de overstapkosten zelf wordt niet bepaald door de mate van (on)tevredenheid. Ongekeerd geldt dat een tevreden klant toch op een andere relatie kan overstappen, bijvoorbeeld vanuit de wens eens iets anders te proberen, en de owerstapkosten hem/haar daar niet van weerhouden.

\section{Relationship Commitment ( $R C)$}

Commitment is de meest gemeenschappelijke, ahankelijke variabele die in studies naar "buyerseller" relaties gebruikt wordt ${ }^{12}$. De geselecteerde variabelen worden geacht positief van inv loed te zijn bij de bepaling van de sterkte van de relatie tussen consumenten en aanbieders van fastmoving-consumer-goods (fmcg"s) en zijn opgenomen in het model, weergegeven door figuur 4.7.
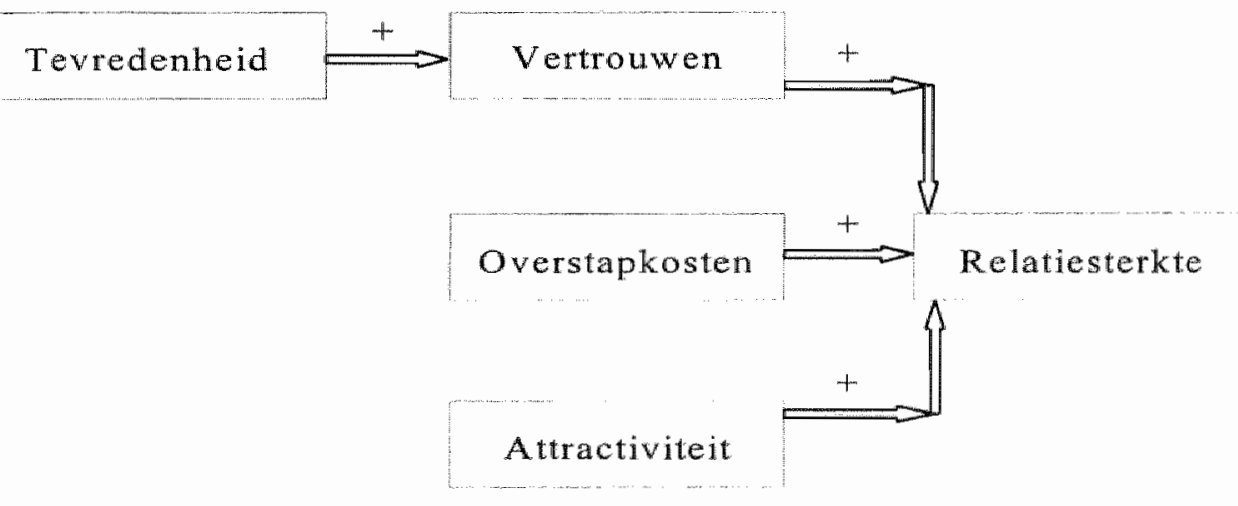

Figuur 4.7 Relatiesterkte als afhankelike van tevredenheid, vertrouwen, gepercipiterde overstapkosten en attractiviteit

12 Jackson, 1985; Dwyer et al., 1987; Wilson en Mummalaneni, 1988; Anderson en Weitz, 1989 en 1992; Morgan en Hunt, 1994; Wilson, 1990 en 1995. 
Verder word verondersteld dat relatieconstructen in een bepaalde fase van de relatie een actieve periode hebben. Een actief relatieconstruct ontvangt en groot deel van de tijd en energie van de relatiepartner(s). In die actieve fase vormt het relatieconstruct het centrum wan het relaticontwikkelingsproces. In een andere fase van de relatie kent het mogelik een latente periode. Daarin is hat construct dan weliswaar nog steeds belangrijk, maar is net actief onder de aandacht wan de refatiepartner(s) tijdens een interactie omdat het naar tevredenheid van de relatiepartner(s) is afgehandeld en daarom geen tijd en/of aandacht krijgt (Wilson, 1990; 1995). Een relatie onwikkelt zich dus, in die zin dat het relatieve belang van de invloedsvariabelen (relaticconstructen) in de loop van de tijd wijzigt. Zo kan de attractiviteit voor de consument wan een relatie met een aanbieder met name bij het aangaan van eem relatie een rol spelen. Na verloop van tijd en het herhaald naar tevredenheid van de consument tegemoetkomen van de witkomsten uit de relatie aan zijn verwachingen, ontstaat vertrouwen in de aambieder en ten aanzien van zinn toekomstige prestaties.

Indien een consument overweegt de relatie met een aanbieder af te bouwen of zelfs te verbreken, zal hij zich een beeld proberen te vormen van de overstapkosten die met die beslissing gemoeid zijn. Overstapkosten zullen dan met name in de latere fasen van de relatielevenseyclus een rol gaan spelen bij de verklaring van relatiesterkte. De hienit voortvloeiende hypothese luidt:

Hypothese 4 Het relatieve belang van de invloedsvariabelen wijzigt in de loop van de tijd, in die zin dat attractiviteit relatief de belangrijkste invloed heeft op relatiesterkte in de opbouwfase van de relatie. Vertrouwen zal relatief de belangrijkste invloedsvariabele zijn in de fase van voortzetting en versterking van de relatie. Overstapkosten zullen relatief de belangrijkste factor van invloed op relatiesterkte vomen bij de overweging de relatie te beëindigen.

Kennis van deze variabelen en de fase in de ontwikkeling van de relatio waarbinnen deze variabelen relatief het belangrijkst zijn (hun actieve periode hebben) is van nut woor marketeers dio op een bepaald moment relatiesterkte meten en hun makketingcommunicatiestrategie daarop willen afstemmen.

\subsection{CONCLUSIE}

Relatiesterkte is door ons gedefinieerd geworden als de sterkte van iemands identificatie met en betrokkonheid bij een organisatie. Voorgesteld werd relatiesterkte to meten via de relationship commitment meetschat, een aan de marketing context aangepaste versie van de organizational commitment questionnaire. Gesteld werd immers dat het domein van het constmuct, afkomstig uit de organisalie literatuur, kan worden uitgebreid naar externe relaties, zoals tussen een aanbieder van fucg's en zijn klanten.

Rolatiesterkte kan gebruiki worden voor het monitoren van relaties en het segmenteren en beschrijven van relaties met behulp van het RLM-model. Het RLM-model is te vergeliken met de produktportfolio. Echter, niet produkten, maar relaties met klanten zijn als analyse-eenheid genomen in het RLM-model. Het is dus de klantrelatie-portfolio die opgesteld en geanalyseerd wordt. 
Een analyse van het RLM-model verschaft inzich in de mogelijkheden relaties met kanten to versterken, hel koopgedrag te benvloeden, danwel beide. Teneinde managers en wetenschappers meer inzicht te bieden in factoren die van invloed zijn op het versterken wan relaties met afnemers, is een model voorgesteld. Daarin wordt relatiesterkte afhankelik gesteld van een aantal antecedenten dat door onderzoek naar voren is gekomen als zijnde van fundamenteel belang in de ontwikkeling van relaties, namelik: tevredenheid, vertrouwen, overstapkosten en attractiviteit. De vraag die daarbij tevens gesteld wordt is of relatiesterkte in de loop van de tijd in dezelfde mate van elk van deze variabelen atharkelijk is. Uiteindelijk dient dit te leiden tot de conclusie dat relaties doelmatiger gemanaged kunnen worden indien hun sterkte adqquat gemeten wordt.

In het onderzoek, dat daartoe zal worden uitgevoerd, wordt zowel het gedrag van, als de belleving bij, de afnemer gemeten. Daar de bij het onderzoek betrokken aanbieders klantenclubs hebben opgericht voor hun klanten en klantenclubs in ons onderzoek als instrument van relatiemarketing en direct marketing geïnterpreteerd zijn, kan als uitgangspunt worden genomen dat de betrokken aanbieders relaties nastreven. Het onderzoek zal onder meerdere groepen afnemers gehouden worden, in plats van onder éen groep. Tevens zal niet éen, maar zullen twee kwantitatieve studies verricht worden: én onder leden en niet-leden van het Gulpener Biergilde en één onder de houders en voomalige houders van de Gall \& Gall wijnkaart. Deze 'multiple study, multiple sample' aanpak zal de betrouwbaarheid en validiteit van RC als meetschaal voor het vaststellen wan relatiesterkte dienen aan te tonen.

Van de resultaten van het voorgenomen onderzoek en de bevindingen ten aanzien van de hypothesen wordt verslag gedaan in de hoofdstukken zes en zeven, nadat in hoofdstuk vij de opzet en uitvoering van het empirische onderzoek witeen is gezet. 


\section{HOOFDSTUK 5: OPZET EN UITVOERING VAN HET ONDERZOEK}

"Een goede herder scheert zijn schapen, maar vilt ze niet"

Gaius Suetonius, Romeins geschedschriver, in: Burgers (1997, p. 9)

\subsection{INLEIDING}

Doel van hoofdstuk 5 is een beschrijuing te geven van de onderzoekmethodologie die gebmikt is om die data te werzamelen die beanwoording van de onderzoeksvagen en de probleemstelling mogelijk maakt. Het hoofdstuk geeft gedetailleerd de onderzoeksprocedures weer. Daartoe is dit hoofdstuk als volgt gestructureerd. In $\$ 5.2$ zal de methode van onderzoek veranmoord worden. In $\$ 5.3$ worden diverse aspecten die met de steekproef samenhangen uiteengezet. In $\$ 5.4$ wardt dieper ingegaan op de gebruikte vragenlisten. Veldwerkaspecten komen in $\$ 5.5$ aan de orde. $\$ 5.6$ Geeft de response gegevens weer, terwijl in $\$ 5.7$ da profielen van de respondenten worden geschetst.

\subsection{METHODE VAN ONDERZOEK}

Het doel van deze studie is om de sterkte vain de relatie met een aanbieder te meten vanuit het perspectief van de consument. Twee aanbieders van 'fast moving consumer goods' (fmcg's), de Gulpener Bierbrouwerij B.V. en slijtersketen Gall \& Gall, participeren in hel onderzoek. Beide aanbieders hebben een klantenclub in het leven geroepen, warmee zij het belang, dat zij hechten aan het opbouwen, onderhouden en versterken van relaties met eindafvemers, tot uitdrukking brengen. Voor de Gulpener studie stonden drie bestanden ter beschikking (leden, ex-leden en potentiele leden van het Gulpener Biergilde) en voor de Gall \& Gall studie waren twee bestanden beschikbaar (leden/kaarthouders en ex-leden/ex-kaarthouders van het Gall $\&$ Gall wijnkaarthoudersprogramma). Hierdoor werd en "multiple study, multiple sample" onderzoaksbenadering mogelijk.

Om ons meetinstrument te testen is het wenselijk dat er spreiding in de waarden van de variabele relatiesterkte wordt aangetroffen. In plaats van achteraf vast te stellen dat er wel of geen sprake is van spreiding in de waarden wan relatiesterkte, kan ook vooraf op die mogelijke spreiding ingespeeld worden door verschillende groepen consumenten in thet onderzoek te betrekken. Door leden, ex-leden en potentiële leden van eenzelfde klantenclub in het onderzock mee te nemen, wordt een meer gedifferentieerd beeld verkregen: de verwachting is dat leden van een klantenclub een sterkere relatie percipiëren dan niet-leden van diezelfde klantenclub (ex-leden en potentiële leden). Naarmate het te testen meetinstrument duidelijker een. onderscheid kan maken tussen leden en niet-leden van de klantenclub kan hat als moer (intern) valide beschouwd worden. Teneinde dus de relatiesterkte van verschillende klantengroepen met elkaar te kunnen vergeljken worden zowel leden als niet-leden in het onderzoek opgenomen. Het gebruik van meerdere steekproeven per studie is om die reden zinvol. 
Daanaast is het wenselijk dat de onderzocksesultaten extern valide zin. Dill betekent dat de resultaten extrapoleerbaar zijn naar andere situaties. Door het meetinstrument in verschillende situaties toe te passen wordt een indruk verkregen var de cxteme validiteit van ons meetinstrument. Hoewe het Gulpener Biergilde en het Gall \& Gall wijnkarthoudersprogramina tot de categone klantenclubs behoren, zijn inhoud en doel van de twee relatiemarkctingprogramma's verschillend! Bovendien is Gulpener een fabrikant die zijn produkten indrect an consumenten levert, terwij Gall \& Gall een slijtersketen is die met consumenten in direct contact staat. Ondanks deze verschilende onderzoekssituaties kunner de ondenoeksresultaten woor beide studies met elkaar overeen komen. De "multiple study" onderzoksbenadering dragt in dat geval positief bij an de (externe) validiteit en generalseerbarheid van de resultaten.

\subsection{STEEKPROEFASPECTEN}

In deze paragraaf wordt een aanal aspecten betreffende de steekproef nader toegelicht. Eerst worden de populaties en steekproekaders beschreven. Vervolgens wordt de steekproefomvang vormeld ende trekkingswijze geschetst. Tot slot word de steekproefsamenstelling vastgelegd.

\section{Popukties en steekproefkaders}

De populatie voon de eerste studie werd gevormd door consumenten van Gulpener bierprodukten die lid, potenticel lid, of ex-lid zijn van het Gulpener Biergilde. De propulatie voor de tweede studie bestond uit kathouders en ex-karthouders van de klantenclub, opgericht door Gall \& Gall. De wee deelnemende organisaties stemden toe in het gebruken van hun bestanden met leden en niet-leden van hun klantenclub als steekproefkaders (lijsten met mamen en adressen).

Het steekproefkader woor de Gulpener studie bestond derhalve uit drie bestanden: leden, exleden en potentiele leden van het Gulpener Biergilde. Het ledenbestand omvatte circa 4.500 personen. Het bestand met ex-leden bestond uit circa 1200 NAW-gegevens. Het derde bestand was opgebouwd nar aanleiding van cen prijstraag en bevatte netto (dat wil zeggen: na verwijdering van leden en exmeden) circa 700 potentiele respondenten. Dit latste bestand werd genomen als proxi voor het bestand van potentiele leden?

Het stokproeknder voor de Gall o Gall shatre bestond uit wee bestanden; een bestand van katrthouders on een bestand van exkanthouders. Beide bestanden bevatten meerdere duzenden loden respectioveligk ex-leden.

\footnotetext{
'In hoodstuk 3 werd het wijnkarthoudersprogramma van Gall \& Gall als een voordeelprogramma en hei Gulpener Biergilde als een chubrogramma geclassificeerd.

${ }^{2}$ Onder leden word verstam. personen die ten tijde van het onderzoek als lid staan ingeschreven. Ex-leden zijn personen de ten tigde van he onderzok niet meer als lid staan ingesehreven.

Als potenticle leden zijn beschotwd: personen die in de 12 maanden voorafgande aan het onderzoek hebben deelgenomen aan een slagzimwedsirid van Gulpener en niet tot de Jeden of ex-leden behoren.
} 


\section{Sieekproefrekking}

In zowel de Gupener studie als de Gall \& Gall sudic is gewerkt met meerdere onaluankelijke steekproeven en wel van het systematische type. Uit elke geleding ${ }^{3}$ wed an steekproef met een onvang van 250 elementen geirokken. De sleekproeven waren aldus disproportioncel. Dat wil in onze studie zeggen dat elke geleding met eenzelfde aantal in ons onderzoek is vertegenwoordigd. Zou over het totaal gerapporteerd worden teneinde uitspraken te doen over de totale populatie van leden en niet-leden gezamenlijk, dan zouden de resultaten van de deelsteekproeven gewogen moeten worden. Het is echter niet de bedoeling om uitspraken over deze totale populatie te doen. Het primaire doel is immers een instrument te ontwikkelen en to valideren dat de relatiesterkte meet. De mogelijkheid het instrunem te testen in cen 'mulliple sudy, multiple sample situatie komt wel tegemoet aan het primaire doel.

\section{Steekproefswinenstelling}

In verband met onder andere non-response, foutieve en afgesloten telefoonnummers, zijn voor de Gulpener studie, per geleding, bruto \pm 700 adressen in de steekproef getrokken. Voor de Gall \& Gall studie betrof dat bruto \pm 750 adressen per geleding. Dat is gebeurd met behulp van een trekkingsinterval. Het trekkingsinterval is per geleding verkregen door het total aantal adressen (N) behorend tot de betreffende geleding te delen door cle gewenste netio $(n=250)$ steekproefomvang. Werd een vraaggesprek geweigerd, dan gaf het CATI-systeen ${ }^{4}$, ad-hoc, een vervangend adres uit de bruto steekproef. Kon ook op dit adres geen vraaggesprek gerealiseerd worden, dan werd de procedure opnieuw in gang gezet. Hetzelfde gebeurde met alle personen, die na vijf maal te zijn benaderd, niet bereikt konden worden.

\subsection{VRAGENLIJST}

\subsubsection{INLEIDING}

In deze paragraaf zal een aantal aspecten behandeld worden dat te maken heef met de samenstelling van de vragenlijsten. Als eerste wordt ingegaan op de volgorde en typering van de vragen en de lengte van de vragenlijst $(\$ 5.4 .2)$. Vervolgens komt de inhoud van de vragenlijst aan de orde $(\$ 5.4 .3)$. De vragenlijsten zijn opgenomen in bijlage 1 voor Gulpener, respectievelijk bijlage 2 voor Gall \& Gall.

\subsubsection{VOLGORDE EN TYPERING VAN DE VRAGEN EN LENGTE VAN DE VRAGENLIJST} Volgorde van de wragen

De totale vragenlijst is in vijf onderdelen verdeeld. Ieder onderdeel levert specificke infomatie, namelijk: transactie-informatie, contact-informatie, informatie over de beleving van de relatic,

\footnotetext{
${ }^{3}$ Er zijn vijf geledingen, namelijk 3 voor Gulpener en 2 voor Gall \& Gall. In het geval van Gulponer betref het: leden, ex-leden en potentiële leden. In het geval van Gall \& Gall gaat het om leden $\mathrm{en}$ ex. leden.

4 Het onafhankelijke marktonderzoekbureau R\&M Reseatrch and Marketing B. V. heeft het weldwerk voor beide studies uitgevoerd middels een telefonische enquête (CATI: 'Computer-Assisted Telephore Interviewng').
} 
infomatic over relatiesterkte (RC) en informatie ten aamzien van de profielen van de deelgroepen.

Voor beide sudies wordi in de vragenlijst eerst geinventariseerd of de respondent lid danwel ex-lid is van de klantenclub. In geval wan Gulpener is ook de optie "geen van beide" mogelijk: de respondent wordt dan aangemerkt als een potentieel lid. Alleen indien de respondent lid is (geweest) uit persoonlijke interesse wordt het gesprek voortgezet. Is de respondent lid (geweest) uit beroepsmatige interesse dan wordt het gesprek afgebroken. Dit is gedaan om het bestand te zuiveren van mensen die beroepsmatig geinteresseerd zijn in het fenomeen klantenclubs. Na deze selectievrag en eventuele inleidende vragen komen de vragen betreffende de onderdelen transactie-informatie, contact-informatie, beleving van de relatie en informatie over relatiesterkte (RC) aan bod. De vragenijsten worden afgesloten met een aantal algemene vragen betreffende geslacht, leeftijd en opleiding van de respondenten.

\section{Typering wan de wagen}

Er is gebrük gemaakt van meerdere vraguormen, zoals vrije-antwoordvragen, dichotome vragen, multiple choice vragen en vragen waarbij gebruik gemaakt wordt var schalen als de Likert-schaal (Weiers, 1984; Zwart, 1994; Churchill, 1995; Cooper en Emory, 1995). Likertschalen worden veelvuldig gebruikt in marktonderzoek ten behoeve van attitudemetingen en zijn voor respondenten gemakkelijk te begrijpen en te beantwoorden ${ }^{6}$. Een aantal items is negatiel geformuleerd teneinde een mogelijke antwoordbias te voorkomen (Belson, 1986).

Het aantal antwoordalternatieven werd in het merendeel van de multiple choice vragen en vragen waarbij gebruik gemaakt werd van een schaal vastgesteld op vijf. Omdat respondenten een neutrale mening kunnen hebben is een oneven aantal antwoordmogelijkheden voor de hand liggend. Daamaast is gebruik gemaakt van de antwoordcategorie "weet niet/wilkan niet zeggen' om te voorkomen dat respondenten zonder mening de neutrale middencategorie kidzen.

\section{Lengle van de vragenlijst}

De lengte van de vragenlijst vomude een potentieel probleem. Een telefonisch interview dat gemiddeld 10 tot 15 minuten duurde werd acceptabel geacht. Gevreesd werd dat de respondent bij een langer durend interview thet gesprek voortijdig zou beëindigen. Daardoor was een uitgebreide vragenlijst uitgesloten. Het verwachte tijdsbeslag werd overigens bij aanvang van hel gesprek aan de respondent medegedeeld. Een mogelijk langer tijdsbeslag dan 15 minuten zou de respondent kunnen doen besluiten af te zien van deelname. Een aantal stappen werd ondemomen om de mogelijke dreigingen ten aanzien van response percentage en gegevenskwaliteit, die door de lengte van de vragenlijst konden worden veroorzaakt, te reduceren. Ten eerste werd de vragenlijst middels 10 tot 15 proefgesprekken getest teneinde

5. Bij mensen die beroepsnatig zijn gehteresseerd in klantenclubs kan gedacht worden aan medewerkers wan concurrenten, reclamebureaus, advesbureaus of organisatics die (vergelijkbare) relatienarketingprogramma's of (sponsored) magazines op de markt brengen. In de Gulpener studie betrof het 43 personen en in de Gall \& Gall studie 35 personen (zie tabel 5.6).

"De Likert-schaal is in essentie een ordinale schalal, maar wordt in de praktijk (met name bij grote steekptoeven en (nagenoeg) nomaal verdeelde variabelen) evenwel vaak als interval schaal behandeld (Weiers, 1984; Zwart, 1994; Churchill, 1995; Cooper en Emory, 1995). 


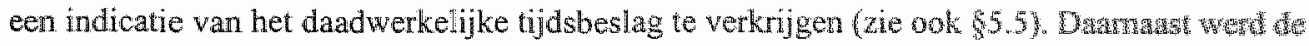
test gebruikt om items, die interpretatieproblemen opleverden voor de rasponutrin passen. De omvang wan de test was te gering om statistische tomtsen toe te passen muma

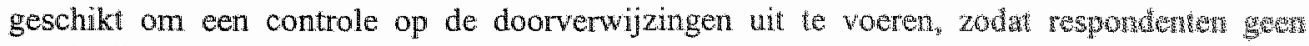

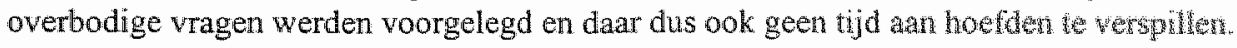

\subsubsection{INHOUD VAN DE VRAGENLIJST \\ Transactie-informatie}

Informatie betreffende de transacties die binnen een relatie platswinden wordt verkeger wa variabelen die enerzijds het koopgedrag betreffen en anderzijds betrekking hebben op di beleving van deze transacties.

Koopgedraggegevens worden verkregen via de vraagnummers 3 tot en met 10,14 en 15 woor de Gulpener studie (zie bijlage 1), respectievelijk de vragnummers 5 tot en met 10, 14 wot sh met 18 voor de Gall \& Gall studie (zie bijlage 2). Zij gaan over:

- de inhoud van de ruil: vinden er aankopen plaats, en zo ja, welke?;

- de duur van de ruil: hoe lang wordt er al gekocht?;

- de recentheid: wanneer is er voor het laatst gekocht?;

- de frequentie van de aankopen: hoe vaak wordt er gekocht?;

- de regelmaat waarmee de aankopen gedurende een jaar plaatswinden;

de geldelijke waarde van de aankopen: voor hoeveel geld wordt maandelijks gekoch?;

de percentuele bestedingen: hoeveel procent van de bier- respectievelijk wijnaankopen wordt aan Gulpener besteed respectievelijk bij Gall \& Gall gekocht;

- het aantal altermatieve merken (respectievelijk aankooppunten) dat (respectievelijk waar) gekocht wordt.

Middels de variabelen 'inhoud', 'duur', 'frequentie' en 'regelmaat' worden viler van de vijt variabelen, aan de hand waarvan volgens Peelen (1989b) de ruil beschreven dient te worden, gemeten. De vijfde door Peelen genoemide variabele, "symmetrie" ("in welke mate leveren beide partijen soortgelijke c.q. verschillende ruilobjecten" (Peelen, 1989b, p. 90)), is niet afzonderlijk meegenomen. In consumentenmarkten leveren onzes inziens beide partijen in aanzienlijke mate verschillende ruilobjecten. Bovendien is in consumentenmarkten, in vergelijking met industriele markten, minder of geen sprake wan wederzijdse afhankelijkheid (Liljander en Strandwik, 1994)7. Ook gelet op de motieven die aanbieders (veelal rationeel) respectievelijk consumenten (naast rationeel ook emotioneel) kunnen hebben voor het onderhouden van een relatie kan veelal niet gesproken worden van een symmetrische relatie (Peelen, 1989b). Bovendien valt de symmetrie volgens Peelen af te leiden uit de antwoorden op de variabelen 'inhoud', 'regelmaat' en 'frequentie'. In dat opzicht is het ook niet nodig 'symmetrie' afzonderlijk op te nemen in de vragenlijst. Wel zijn 'recentheid', 'geldelijke waarde' en "percentuele bestedingen' opgenomen in de vragenlijst. Recentheid en gejdelijke waarde zijn immers belangrijke variabelen die, samen met frequentie, in direct marketing gebruikt worden om het koopgedrag in kaart te brengen en om klanten als waardevolle respectievelijk minder waardevolle klanten te classificeren. Dit gebeurt op basis van de RFMformule. De variabele 'percentuele bestedingen' is opgenomen omdat de absolute bestedingen

${ }^{7}$ Hierbij kan nog worden opgemerkt dat ook de rol die afhankelijkheid speelt bij het opbouwen van (i.c. industrielle 'buyer-seller') relaties weel kleiner is dan in het algemeen tot nog toe werd. aangenomen (Geyskens et al., 1996). 
in feite geen informatie verschaffen over het klantaandeel ("customer share"), een variabele die in relatiemarketing de voorkeur geniet boven marktaandeel (Vavra, 1992). Daarnaast kan opgemerkt worden dat iemand die in absolute termen weinig besteedt, maar wel $100 \%$ van zijn bestedingen (zijn complete budget) bij één aanbieder onderbrengt, als loyaler gezien kan worden dan iemand die in absolute bedragen weliswaar meer besteedt, maar zijn budget over meerdere aanbieders verdeelt. Tevens verschaft deze variabele informatie over de mogelijk nog te verwerven bestedingen.

Het belevingsaspect van de ruil wordt gemeten middels de vragen 11 tot en met 13 , zowel voor de Gulpener studie als voor de Gall \& Gall studie.

De vragen hebben betrekking op:

- de absolute tevredenheid met de ruil, i.c. prijs-kwaliteit verhouding, dus zonder te wergelijken met alternatieven;

de relatieve tevredenheid met de ruil: hoe tevreden is de consument indien de prijskwaliteit verhouding wél wordt vergeleken met altematieven?;

de evaluatie van de ruil: wordt na de ruil nog eens over de gemaakte keuze nagedacht?

Tabel 5.1 geeft voor beide studies aan welke gegevens middels welke items in de vragenlijst verzameld zijn.

"Trabe 5.1 Vragen die transactie-informatic verschaffen

\begin{tabular}{|c|c|c|}
\hline Wragen & $\begin{array}{l}\text { Wraggnunner } \\
\text { Gulpener Srudie }\end{array}$ & $\begin{array}{l}\text { Wragmumner } \\
\text { Gall \& Gall Sudie }\end{array}$ \\
\hline \multicolumn{3}{|l|}{ Koopgedrang } \\
\hline Koopt wel eens & 3 & 5 \\
\hline Hoe lang al kopen & 4 & 6 \\
\hline Recenthueid Jantste ankoop & 5 & 7 \\
\hline Frequentie ankopen & 6 & 8 \\
\hline Regelmat adnkopen & 7 & 10 \\
\hline Besteding gen gemidde ld per maand & 8 & 9 \\
\hline Pencontucle bewtedingen & 9 & 14 \\
\hline Anntal andere merken gekocht & 10 & - \\
\hline Aantal conewrerende asukooppunt to roor wija & - & $15 ; 16$ \\
\hline Breedte van het assortiment at gekocht wordt & $14 ; 15$ & $17 ; 18$ \\
\hline \multicolumn{3}{|l|}{ Deteving } \\
\hline Absolute tevredentieid met prijs/kwalite th & 11 & 11 \\
\hline Relatieve tevred crheid met prijs/kwaliteit & 12 & 12 \\
\hline Evaluatie na hedere ankoop & 13 & 13 \\
\hline
\end{tabular}




\section{Contact-informatie}

Informatie betreffende de contacten die bimen een relatie plaatsvinden wordt werkregen via variabelen die enerzijds het contactgedrag betreffen en anderzijds betrekking hebben op de beleving van deze contacten. Met uitzondering van de variabelen 'geldelijke waarde" en "percentuele bestedingen' treffen we hier dezelfe variabelen aan als bij het onderdeel "transactie-informatie". De contacten kunnen weliswaar gepaard gaan mèt de ruiltransactie, maar worden geacht niet deel uit te maken vàn de ruiltransactie.

Het contactgedrag wordt gemeten met behulp wan de vragen 16 tot en met 20 en 24 voor de Gulpener studie, respectievelik 19 tot en met 23 voor de Gall \& Gall studie. Deze vragen leveren informatie ten aanzien van:

- de inhoud van de contacten: op hoeveel en welke wijzen komt men in aanraking met de organisatie?;

de duur van de contacten;

de recentheid van het laatste contact;

de frequentie van de contacten;

de regelmaat waarin de contacten plaatsvinden.

Vraag 24 (Gulpener studie) tenslotte geef aan of de respondent zelf ook initiatief neemt tot het onderhouden van contacten met de organisatie. Bij de Gall \& Gall studie is deze vraag niet meegenomen daar het daar om kopers van wijn bij Gall \& Gall handelt. Met andere woorden: gesteld kan worden dat zij, om wijn bij Gall \& Gall te kunnen kopen, zelf initiatief moeten nemen en naar de Gall \& Gall vestiging toe moeten gaan om het contact en de eventuele transactie te kunnen bewerkstelligen. Dit in tegenstelling tot kopers van Gulpener bier, waar de merkkeuze niet per definitie plaatsvindt op initiatief van de koper (denk bijvoorbeeld aan bezoek aan cafe of restaurant).

Het belevingsaspect van de contacten wordt gemeten middels de vragen 21 tot en met 23 voor de Gulpener studie, respectievelijk 24 tot en met 26 voor de Gall \& Gall studie.

Zij gaan over:

de absolute tevredenheid met de contacten;

de relatieve tevredenheid met de contacten; de evaluatie van de contacten.

Tabel 5.2 geeft woor beide studies an welke gegevens middels welke items in de vragenlijst verzameld zijn. 
Tabul 5.2 Vragen die contactinformatie verschafen

\begin{tabular}{|c|c|c|}
\hline Vragen & 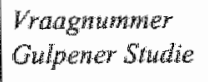 & $\begin{array}{l}\text { Wragmmmmer } \\
\text { call o Gall Stude }\end{array}$ \\
\hline \multicolumn{3}{|l|}{ Contacrgedrag } \\
\hline Aantial contactwijzen & 16 & 19 \\
\hline Hoe lang geleden verste contane & 17 & 20 \\
\hline Recentheid laatste contact & 18 & 21 \\
\hline Frequenthe contacten & 19 & 22 \\
\hline Regelmatat contatcten & 20 & 23 \\
\hline Contact op ergen intiatief & 24 & - \\
\hline \multicolumn{3}{|l|}{ Heleving } \\
\hline Absolute dertedenheid contacten & 21 & 24 \\
\hline Relatieve tevedenheid contacten & 22 & 25 \\
\hline Evaluatie na ieder contact & 23 & 26 \\
\hline
\end{tabular}

\section{Belewing van de relatie}

Ten behoeve van de modelspecificatie zijn de constructen vertrouwen, gepercipieerde overstapkosten, attractiviteit en tevredenheid in de vragenlijst opgenomen. De operationalisering van deze constructen voor de Gulpener studie vertoont enige verschillen met die voor de Gall \& Gall studie. De Gulpener sudie was opgezet om de mogelijkheden van een model te onderzoeken en vond eerder plaats dan de Gall \& Gall studie. De ervaringen opgedaan bij de Gulpener studie werden gebruikt om voor de Gall \& Gall studie tot een meer veranwoorde operationalisering te komen. De operationalisering van de constructen vertrouwen, gepercipieerde overstapkosten, attractiviteit en tevredenheid wordt woor beide studies afzonderlijk kort besproken.

De beleving van de relatie word voor de Gupener studie gemeten middels de vragen 29, 30, $41,42,46$ en 47 . De vragen hebben achterenvolgens betrekking op:

- de overstapkosten: welke risico's, kosten en/of moeite zijn verbonden aan het stoppen met de huidige relatie en/of het angaan van een nieuwe relatie?;

het vertrouwen dat consumenten hebben in de organisatie;

de tevredenheid in het algemeen met de organisatie en haar produkten;

de attractiviteit van de organisatie vergeleken met altematieve aanbieders.

De beleving van de relatio wordt voor de Gall \& Gall studie gemeten middels de vragen 28 tot en met 33,38 tot en met 40 en 44 tot en met 49 .

De vragen 28 tof en met 33 hebben betrekking op de gepencipieerde overstapkosten.

De vragen 28 en 29 refereren aan de risico's die de respondent meent waar te nemen bij het beëindigen van de bestaande, respectieveljk het aangaan van een nieuwe band. Door gebrek aan ervaring kan een verkeerde inschatting gemaakt worden ten aanzien van onder andere de verkrigbaarheid van produkten bij, en kwaliteit van de dienstverlening door, de nieuwe aanbieder (Peelen, 1989b). 
Vragen 30 en 31 refereren aan de mogelijke kosten verbonden aan het beandigen respectievelijk aangaan van een band: het geld dat met de overstap is gemoeid (Peelen, 19896$)$. De vragen 32 en 33 refereren primair aan de problemen die men ervaart bij cen eventuele overstap naar een ander aankooppunt: de inspanning en tijd die het overstappen vergt (Peelen. 1989b).

Het vertrouwen van respondenten in de organisatie (Gall \& Gall) wordt gemeten via de itens 38,39 en 40 . Vragg 38 is ontleend aan Dwyer en Oh (1987). Vraag 39 is oorspronkelijk van John en Reve (1982).

De vragen 44 en 45 hebben betrekking op de tevredenheid in het algemeen met de organisatie en haar produkten. Zij zijn ontleend aan Gaski (1986), Dwyer en Oh (1987) en Crosby et al. (1990).

De vragen 46 tot en met 49 hebben betrekking op de attractiviteit. De vier items zijn gebaseerd op Peelen (1989b) en hebben betrekking op de antrekkelijkheid wan het assortiment (vragen 46 en 47), respectievelijk de attractiviteit ten opzichte van andere aankooppunten voor wijn (vragen 48 en 49) (zie ook Crosby et al., 1990).

Naast bovengenoemde constructen zijn er nog andere aspecten gemeten die mogelijk meer fundament kunnen geven aan de management implicaties die voortvloeien uit het RLM-model. Daarbij kan in het bijzonder gedacht worden an hoe respondenten de huidige relatic, respectievelijk de gewenste relatie met de aanbieder zouden classificeren. Daartoe zijn de vijf niveaus van relaties, die door Kotler $(1992 ; 1994)$ onderscheiden worden, aangewend. Kotler beschrijft vijf niveaus waarop een relatie met kopers van een produki onderhouden kumen worden. In toenemende mate van intensiteit onderscheidt Kotler (1994) de volgende niveaus: 'basic', 'reactive', 'accountable', "proactive' en 'partnership'.

Via een tweede meettechniek is (in de Gulpener studie) getracht om op een andere wijze een indicatie te krijgen van de mate van commitment. Dit 'alternatief commitment construct" bestond uit vier items ontleend aan Bloener (1993a).

De vragen 25 tot en met 28 (Gulpener) hebben betrekking op de betrokkenheid van de respondenten bij de Gulpener organisatie. Het zijn vier items van een semantische differentiaal, die zijn ontleend aan Bloemer (1993a). De vragen 41,42 en 43 (Gall \& Gall) hebben betrekking op de betrokkenheid van de respondenten bij de keuze van een ankooppunt voor wijn. Deze drie items zijn ook ontleend an Bloemer (1993a), maar nu betreft het drie items van de Likert-schaal.

'Reden keuze' (in de Gulpener studie) betreft een drietal items warbij het gaa om de reden(en) voor het gebruiken wan het produkt, i.c. Gulpener bier: heef de reden betrekking op het eigen ego, op de organisatie, of op het produkt zelf.

Verder is op verzoek van Gall \& Gall gevraagd naar het oordeel wan de respondenten over het lidmaatschapsgeld voor de wijnkaart.

Andere items hebben betrekking op de vraag:

in welke mate fouten geaccepteerd worden;

of in geval van fouten een klacht wordt ingediend;

of ook andere merken (respectievelijk aankooppunten) in beschouwing genomen worden; of men verwacht in de toekomst meer of minder te gaan besteden;

in welke mate de band zich gewijzigd heeft naar aanleiding van (beeindiging wan) het lidmaatschap. 
Het is mogelijk dat een verschil in relatiesterkte in deze aspecten tot uitdrukking komt. Zo is het denkbaar dat iemand die cen sterke relatie percipieert: minder bereid is fouten te accepteren an in geval wan fouten exder een klacht indient; geen of nauwelijks andere merken (respectievelijk ankooppunten) in beschouwing neem; verwacht in de toekomst meer te gaan besteden.

Tabel 5.3 geeft voor beide studies aan welke gegevens middels welke items in de vragenlijst verzameld zijn.

Talhel 5.3 Vragen dix de beleving van de relatie meten

\begin{tabular}{|c|c|c|}
\hline Hagen & Wratgmumer Gulpener Stadie & Vradgnummer Gall a Gall Sindie \\
\hline \multicolumn{3}{|l|}{ Model } \\
\hline Gopercipiterde overstapkosten & $29 ; 30$ & $28 ; 29 ; 30 ; 31 ; 32 ; 33$ \\
\hline Verffoumen & $41: 42$ & $38 ; 39 ; 40$ \\
\hline Tevrederaheid algetheel & 46 & $44: 45$ \\
\hline Attractiviteit & 47 & $46 ; 47 ; 48 ; 49$ \\
\hline \multicolumn{3}{|l|}{ Overig } \\
\hline Commitment alternatio: & $36 ; 37 ; 38 ; 40$ & * \\
\hline Betrokkenheid & $25 ; 26 ; 27 ; 28$ & $41 ; 42 ; 43$ \\
\hline Acceptatie fouten & 31 & 27 \\
\hline Klacht ind ienen bij rout & 32 & 34 \\
\hline Huidige relatie & 33 & 35 \\
\hline Gewenste relatic & $34 ; 35$ & $36 ; 37$ \\
\hline Neemt ook concurrentie in beschouwing & 39 & 51 \\
\hline Reden keuze & $43 ; 44 ; 45$ & - \\
\hline Toekonetperspected" & 48 & 50 \\
\hline Wigrging band & $64 ; 65$ & $67 ; 68$ \\
\hline Oordeal contributie wijnkart & - & 69 \\
\hline
\end{tabular}

\section{Relationship Cowmitmen ( $R C)$}

De basis voor dit construct werd gevonden in de Organizational Commitment Questionnaire (OCQ) (Mowday et al., 1979; Mowday et al., 1982). De OCQ bestaat uit 15 items van het 7punts Likert-type met als uiteinden 'volledig eens" en "volledig oneens' (zie bijlage 5). Deze schal is oorspronkelijk ontwikkeld voor het meten van de binding van de werknemer met zijn werkgevende organisatie. Teneinde de OCQ geschikt te maken voor een consumentenmarketing context waren enkel geringe modificaties noodzakelijk voor slechts enkele van de 15 items. Daarbij werd tevens gebruik gemaakt van de bevindingen van Morgan en Hunt (1994) en Kelley en Davis (1994) die eveneens de OCQ als basis gebruikten voor het commitment construct in hun onderzoek. De items werden in ons telefonische onderzoek 
middels een in Nederland meer gebrukelike 5 -punts Likert-schaal gemeten. Tabel 5.4 geeft voor beide studies aan welke items in de vagenlijst tot de RCQ behoren.

Tabel 5.4 Items van de Relationship Commitment Questionaire

\begin{tabular}{|c|c|c|}
\hline Vragen & Fragnammer Gulpener Sudie & Vranghammer Goll a Goll Shathe \\
\hline $\mathrm{RCQ}$ & 49 tot en met 63 & 52 tot en met 66 \\
\hline
\end{tabular}

De verschillen in de formulering van de items voor de Gulpener studie en voor de Gall \& Gall studie zijn gebaseerd op de ervaringen voortgekomen uit de Gulpener studie en de specifieke context van de Gall \& Gall studie. Zo is bijworbeeld in de Gall \& Gall studie de prijsverhoging niet op $10 \%$ maar op $5 \%$ gesteld. De wijnkaat immers woonziet in een konting Wan $10 \%$ op de aankopen. Een prijsverhoging van $10 \%$ zou in dat opzich het voordeel van de wijnkaart geheel teniet doen. Venwacht mag worden dat ook leden dit niet zouden accepteren.

\section{Profiel van de deelgroepen}

De demografische/socio-economische kenmerken worden gemeten middels de vragen 1 en 2 (respectievelijk 1 en 3) en de vragen 66 to en met 68 (respectievelik $70 \mathrm{t} / \mathrm{m}$ 72). Daarin wordl onder andere gevraagd naar:

\section{- geslacht;}

- leeftijd;

- opleiding; en,

\section{- (duur van het) lidmatschap.}

De Gall \& Gall studie bevatte daarnaast op verzoek van Gall \& Gall een tweetal open vragen. De vraag waarom de respondent geen wijnkaarthouder meer was en de vraag waaron de respondent houder van de wijnkaart was geworden.

Tabel 5.5 geeft voor beide studies aan welke gegevens middels welke items in de vragenlijst verzameld zijn.

Tabel 5.5 Vragen die profielgegevens van de respondenten verschaffen

\begin{tabular}{|c|c|c|}
\hline Vhagen & Fraginummer Gulpener Studie & 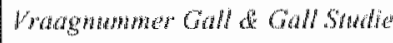 \\
\hline Lidmaatschap & 1 & 1 \\
\hline Dutur lidmatschap & 2 & 3 \\
\hline Geslacht respondent & 66 & 70 \\
\hline Leefijid respondent & 67 & 71 \\
\hline Hoogstgenoten opleiding respondent & 68 & 72 \\
\hline Watarom (geen) houder/lid (meer) & - & $2: 4$ \\
\hline
\end{tabular}




\subsection{VELDWERK}

Voorafgaand aan de onderzoeken bij Gulpener en Gall \& Gall werd een eerste verkennende studie uitgevoerd naar de mogelijkheid relatiesterkte in consumentenmarkten te meten. Het betrof zowel een literatuurstudie als een empirisch onderzoek onder leden, ex-leden en potentiële leden van het Gulpener Biergilde (Schröder, 1994). In dat onderzoek vond een eerste uitgebreide test plaats van vragen, constructen, vragenlijsten en de mogelijkheid relatiesterkte te meten. De ervaringen opgedaan in dat onderzoek werden meegenomen naar het onderhavige onderzoek.

Ook ten behoeve van het onderhavige onderzoek werden de vragenlijsten wederom uitvoerig getest. De eerste testfase bestond uit het vergaren van reacties van collega"s ten aanzien van de vragenlijsten met het oog op het verbeteren van de inhoudsvaliditeit van de gebruikte schalen. Vervolgens werden de vragenlijsten voorgelegd aan medewerkers van het marktonderzoekbureau dat het onderzoek zou gaan uitvoeren teneinde vanuit hun specifieke expertise een bijdrage te leveren aan het verbeteren van de diverse aspecten van de vragenlijsten. De vragenlijsten werden tevens besproken met vertegenwoordigers van de bij het onderzoek betrokken organisaties teneinde ook hun specifieke wensen, ideeën en inzichten zoveel mogelijk mee te nemen. Na verwerking van de suggesties van deze experts werden de vragenlijsten op kleine schaal in de praktijk getest door tien tot vijftien proefgesprekken af te nemen en deze gesprekken te analyseren. De veranderingen die op basis daarvan werden aangebracht hadden met name betrekking op het doorverwijzen binnen de vragenlijst. Aansluitend daarop wonden de studies in wolle omvang plaats.

De telefonische vraaggesprekken werden door ervaren enquêteurs en enquêtrices gehouden. Daartoe kregen zij eerst een uitgebreide mondelinge instructie van de onderzoeker, waarin zij vertrouwd werden gemaakt met het doel van het onderzoek, de structuur en inhoud van de vragenlijsten en de bedoeling van de individuele vragen.

De twee studies vonden om praktische redenen niet parallel maar volgtijdelijk plaats. Op deze wijze konden in de tweede studie (Gall \& Gall) leereffecten van de eerste studie (Gulpener) worden toegepast (voorzover noodzakelijk), zoals dat eerder had plaatsgevonden met de leereffecten die voortkwamen uit de eerste verkennende studie door Schröder (1994). Binnen een tijdsbestek van twee tot drie weken waren de gegevens voorhanden. Het veldwerk voor de Gulpener studie werd verricht in de periode 28 november tot en met 15 december 1995 (tussen 17.30 uur en 21.30 uur). Daarbij waren in totaal 21 enquêteurs/enquêtrices betrokken. Het veldwerk voor de Gall \& Gall studie werd verricht in de periode 27 mei tot en met 7 juni 1.996 (tussen 17.30 uur en 21.30 uur). Daarbij waren in totaal 25 enquêteurs/enquêtrices betrokken.

Nadat de verzamelde gegevens waren opgeslagen kon worden overgegaan tot het editen van de bestanden zodat ze geschikt waren voor verdere data-analyses.

Zo werden de antwoordscores op negatief geformuleerde items ongekeerd om de antwoorden in overeenstemming te brengen met de overige (positief geformuleerde) items (Weiers, 1984). In de, in de bijlagen 1 en 2 opgenomen, vragenlijsten zijn de aanpassingen met betrekking tot de antwoordscores reeds aangebracht. In de Galı \& Gall studie is een aantal open vragen opgenomen. Deze vragen hadden een exploratief karakter. De antwoorden op deze vragen zijn

\footnotetext{
In ons onderzoek werd gebruik genaakt wan aselecte steekproeven die onafhankelijk waren van de aselecte steekproeven getrokken ten behoeve van het onderzoek vam Schröder (1994). In ons onderzoek is daardoor met veelal andere respondenten gewerkt dan in het onderzoek van Schröder.
} 
achteraf door drie personen (de onderzoeker en twee assistenten) onafhankelik wan ekar in categorieän ondergebracht en gecodeerd ('post-coding;, Zwart, 1994). Deze aanpak leidde tor zowel een consistente indeling als eindrangschikking (zie bijlage 3 ).

De resulterende bestanden werden als de werkbestanden beschouwd waarmee verdere analyses werden uitgevoerd.

\subsection{RESPONSE GEGEVENS}

Een overzicht wan de bruto steekproef tot en met het totatal aantal geslaagde en venwerkte telefoongesprekken, zowell woor de Gulpener studie als voor de Gall \& Gall studic, wordt weergegeven in tabel 5.6 .

De 758 gesprekken uit de Gulpener studie zijn als volgt uit de onderscheiden bestanden afkomstig:

- bestand leden Gulpener Biergilde: 256 gesprekken uit

- bestand ex-leden:

266 gesprekken uit

342 benaderingen $(75 \%)$

- bestand potentiele leden:

236 gesprekken uit

Total:

758 gesprekken uit

423 benaderingen $(63 \%)$

415 benaderingen $(57 \%)$

1180 benaderingen $(64 \%)$

Uiteindelijk resulteerde dit in een gegevensbestand ten behoeve van de Gulpener studie bestaande uit:

-315 leden van het Gulpener Biergilde

-237 ex-leden

- 202 potentiële leden

- 754 respondenten (exclusief vier respondenten waarvan de 'status' niet bekend is).

Uit de nubrieken 'foutieve opgave' en 'overleden/...' in tabel 5.6 blijkt reeds, dat de gebruikte bestanden niet helemaal "up to date' waren. Dit probleem komt ook tot uitdrukking in het gegeven dat 315 respondenten aangaven lid te zijn, terwijl slechts 256 gesprekken wit het ledenbestand van hef Gulpener Biergilde waren voortgekomen. Blijkbear stakt cen aantal respondenten (reeds) als ex-lid danwel (nog) als potenticel lid geregistreend terwijl zij zichlizell (nog respectievelijk reeds) als lid beschouwen. Voor ons onderzoek is de opgave wan de respondent als uitgangspunt genomen.

De 500 gesprekken wit de Gall \& Gall studie zijn als volgt uit de onderscheiden bestanden afkomstig:

- bestand kaarthouders:

- bestand ex-kaarthouders:

211 gesprekken uit

469 benaderingen $(45 \%)$

289 gesprekken uit

662 benaderingen $(43 \%)$

Totaal:

500 gesprekken uit

1131 benaderingen $(44 \%)$

Uiteindelijk resulteerde dit in een gegevensbestand ten behoeve van de Gall \& Gall studie bestaande uit:

- 261 kaarthouders

- 239 ex-kaarthouders

- 500 respondenten. 
Ook hier doet zich een afwijing woor, daar 50 respondenten aangeven (nog) kaarthouder te zijn terwijl zij (reeds) zijn opgenomen in het bestand van ex-kaarthouders.

Die response wan leden blijkt, met name in de Gulpener studie, hoger te zijn dan die wan nietleden. Dit was overeenkonstig de verwachting die gebaseerd was op de resultaten van een eerste verkennende studie van Schroder (1994)9.

Tabel 5.6 Overzicht stekproefgegewens Gulpener studie en Gall \& Gall studie

\begin{tabular}{|c|c|c|c|c|c|c|}
\hline \multirow[b]{2}{*}{ Bruto sited provef } & \multicolumn{3}{|c|}{ Gulpener Studie } & \multicolumn{3}{|c|}{ Gall \& Gall Studie } \\
\hline & & 2196 & & & 1697 & \\
\hline \multicolumn{7}{|l|}{ 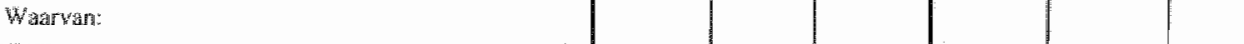 } \\
\hline - niet benaderd & 545 & & & 184 & & \\
\hline \multirow[t]{3}{*}{ - fouticyo opgawe (bedrifsadres/fout adres) } & 91 & & & 66 & & \\
\hline & & $236-1$ & & & $250-$ & \\
\hline & & 1460 & & & 8447 & \\
\hline \multicolumn{7}{|l|}{ Warwan: } \\
\hline - felefoon afgesloten/geen felefoon/gehem nummer & 100 & & & 209 & & \\
\hline - butenlandertasiproblemen & 5 & & & 14 & & \\
\hline - overled & 15 & & & 4 & & \\
\hline - vakann live/afwezig tijdens onderzoekperiode & 27 & & & 54 & & \\
\hline \multirow{3}{*}{$\begin{array}{l}\text { - respondent woldoet nitet aun steekproeferiteria } \\
\text { (geen persoonilgk lid (geweest)) }\end{array}$} & 43 & & & 35 & & \\
\hline & & $280-1 \%$ & & & $316-1 *$ & \\
\hline & & 1180 & $100 \%$ & & $1|3|$ & $100 \%$ \\
\hline \multicolumn{7}{|l|}{ Wabryan: } \\
\hline 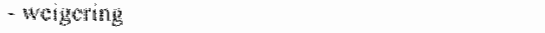 & 354 & & & 4.40 & & \\
\hline 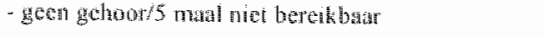 & 28 & & & 147 & & \\
\hline \multirow{2}{*}{ - nict verwerkbarigesprok argebroken } & 40 & & & 44 & & \\
\hline & & $422-1$ & $36 \%$ & & $631 \%$ & $50 \%$ \\
\hline Tothal geslangd or werther & & 758 & $64 \%$ & & 500 & $44 \%$ \\
\hline
\end{tabular}

"Deze studie, die solriftelijk platsvond, leverde voor ex-leden wan het Gulpener Biergilde een response op van $15.7 \%$, in tegenstelling tot potentièle leden en leden van het Biergilde waarvan respectievelijk $28.8 \%$ en $73.4 \%$ respondeerde (Schijns en Schröder, 1996). Dit duidt op de aanwezigheid van een slerkere interesse in en betrokkenheid bij het onderzoek bij de leden in vergelijking met niet-leden. 
Het opmerkelijke verschil tussen beide studies voor wat betref het antal afwezigen tijdens de onderzoekperiode (onder andere in verband met vakantie) en het aantal mensen dat ook bij de wijfe maal bellen geen gehoor gaf, is mogelijk te verklaren aan de hand van de periode watrin de onderzoeken hebben plaatsgewonden. Zoals eerder aangegeven vond het veldwerk voor de Gulpener studie plats in de periode 28 november tot en met 15 december, terwijl het veldwerk voor de Gall \& Gall studie werd werricht in de periode van 27 mei tot en met 7 juni. Als gevolg daarvan is het vakantie-effect in de Gall \& Gall studie duidelik merkbaar.

Die responsegraad is relatief belangrijk. In de regel zullen klanten met een utgesproken mening, de ontevredenen en de heel tevredenen bijvoorbeeld, meer geneigd zijn on te antwoorden. Indien vooral de extremen geneigd zijn te reageren, dreigen de resultaten vertekend te worden en kan het onderzoek niet als representatief beschouwd worden. De meetresultaten zijn dan enkel representatief als de responsegraad voldoende hoog ligt (De Pelsmacker en Van Kenhove, 1994). Voor zover de resultaten relatief worden gebruikt, is het probleem van representativiteit wan ondergeschikt belang. In principe bljift de non-response fout constant, zodat een relatieve interpretatie van de resultaten mogelijk blijft (De Pelsmacker en Van Kenhove, 1994). Ondat in ons onderzoek het profiel wan de klanten die niel geantwoord hebben niet beschikbaar is, is een controle op de non-response fout niet mogelijk, met andere woorden: een vergelijking van het profiel van respondenten met het profiel van non-respondenten kan niet worden toegepast.

In het algemeen kan het onderzoek naar onze mening echter als representatief beschouwd worden. In ons onderzoek ligt namelijk de response woor elke deelgroep afzonderlijk, en daamee ook voor het totaal, zowel in aantallen als in percentages, vrij hoog. Dit is mede toe te schrijven aan de gehanteerde onderzoeksbenadering. In het algemeen is de response in geval van een telefonische benadering, zoals door ons toegepast, beduidend hoger dan bij de schriftelijke en weinig lager dan bij de mondelinge benadering (Churchill, 1995). Daarnatast is de bereidheid van respondenten om mee te werken beïnvloed door de anonimiteit te garanderen en de naam van de opdrachtgever niet geheim te houden. Tevens zijn, zoals uit tabel 5.6 blijkt, maar liefst tot 5 belpogingen ondernomen om de beoogde respondent te bereiken, mocht deze in eerste instantie geen gehoor geven. Cooper en Emory (1995) geven aan dat het uitvoeren van voldoende 'callbacks' (minimal 3) de meest beirouwbare oplossing voor het non-response probleem is. Bovendien zijn de belpogingen daarbij op verschillende tijden en dagen ondemomen, hetgeen bijdraagt aan de effectiviteit van "calbacks" (Churchill, 1995; Cooper wn Emory, 1995). Ook werden respondenten persoonlijk aangesproken hetgeen mogelijk was moel behulp wan de beschikbare databestanden met NAW-gegevens. Een persoonlijke benadering wordt genoend als aanbeveling om de non-response te reduceren (Zwart, 1994). Indien het tijdstip wan benadering niet geschikt werd bevonden werd gevragd of de respondent op een voor hem/haar geschikt moment teruggebeld kon worden. Er werd echter geen premium in het vooruitzicht gesteld als poging thet response percentage te verhogen. In de tradle-off die bestal tussen response percentage en gegevenskwaliteit werd de voorkeur gegeven an de kwaliteit van de gegevens. Additioneel geeft de gehanteerde steekproefmethode en steekproeftrekkingswijze, zoals in $\$ 5.3$ uiteengezet, reden to veronderstellen dat de steekproef per deelgroep een goede afspiegeling is van (representatief is voor) die deelgroep. Naar wanleiding van deze initiatieven met als doel de non-response te minimaliseren, is er geen specifieke reden on aan te nemen dat bimen elk van de deelgroepen in het bijzonder de tevredenen, de meest ontevredenen, of de meest geinteresseerden in het onderwerp van studic 
hun medewerking hebben verleend en dat er als gevolg daarvan sprake is van selectieve monresponse.

\subsection{PROFIELEN VAN DE RESPONDENTEN}

De profielen van de respondenten zijn gebaseerd op de door de respondenten in de wraaggesprekken verstrekte gegevens betreffende: geslacht, leeftij, hoogstgenoten opleiding en, indien lid, sinds wanneer men lid is.

\section{Profiel van de drie deelgroepen van Gulpener}

De meeste leden $(77 \%)$ zijn sinds 1991 (jaar van oprichting van het Gulpener Biergilde) lid. Het overgrote merendeel van de respondenten is man (in geval van leden: $95.9 \%$, in geval van ex-leden: $98.3 \%$, en in geval van potentielle leden: $80.2 \%$. Het lidmaatschap wordt dus bijna witshutend op de naam van de man aangegaan. De modale leeftijdsklasse is voor leden en potentiele leden 40-49 jaar, terwijl voor ex-leden de klassen 30-39 jaar en 40-49 jaar als modale klassen naar voren komen. Een hogere beroepsopleiding is voor zowel leden, ex-leden als potentielle leden de relatief meest genoemde hoogst genoten opleiding.

\section{Profiel van de twee deelgroepen van Gall \& Gall}

De leden zijn gemiddeld reeds drie jaar lid. $25 \%$ van de leden is in 1994 (madus en mediaan) lid geworden. Het merendeel van de respondenten is man (in geval van leden: $62.8 \%$, in geval van ex-leden: $61.1 \%$, hetgeen tevens impliceert dat het lidmaatschap veelal op de naam van de man wordt aangegaan. De modale leeftijdsklasse is voor leden en ex-leden $40-49$ jaar. Een hogere beroepsopleiding is voor leden en ex-leden de relatief meest genoemde hoogst genoten opleiding.

\subsection{CONCLUSIE}

In dit hoofdstuk is de opzet en uitwoering uiteengezet van de twee studies die dit onderzoek omval. Als methode van dataverzaneling is gekozen voor een "multiple study, multiple sample' onderzoeksbenadering. Daarbij werden in de eerste studie leden, ex leden en potentièle leden van het Gulpener Biergilde benaderd. In de tweede studie werden leden en ex-leden van het wijnkaarthoudersprogramma van Gall \& Gall ondervraagd. Als steekproefkaders kon gebruik worden gemaakt van bestanden met NAW-gegevens die door de deenemende organisaties werden aangeleverd. In beide studies is gewerki met meerdere onafhankelijke steekproeven war het aselecte, systematische type. Per deelgroep/bestand werd een (disproportionele) netto steekproef van circa 250 respondenten getrokken. Bij het inhoud geven aan de vragenlijst is gebruik gemaakt van meerdere vraggomen: vrije-antwoordvragen, dichotome vragen, multiple choice vragen en vragen waarbij gebruik gemaakt wordt van schalen als de Likert-schaal. De lengte van de vragenlijst werd mede bepaald door het gegeven dat deze telefonisch werd afgenomen en gemiddeld niet meer dan 10 tot 15 minuten in beslag zou nemen.

De vagenlijst is opgebonwd wit een vijftal onderdelen: transactie-informatie, contactinformatie, beleving van de relatie, informatie over relatiesterkte (RC) en infomatie ten 
aanzien van de profielen van de deelgroepen. Voor wat betreft de transactie-informatie is nader ingegaan op zaken als: inhoud en duur van de transacties; recentheid van de laatste aankoop: frequentie, regelmaat en geldelijke waarde van de aankopen; percentuele bestedingen, alsmede tevredenheid met de aankopen. Contactwinformatie had onder andere betrekking op: inhoud en duur van de contacten; recentheid van het laatste contact; frequentie en regelmat van de contacten, allsmede de tevredenheid met deze contacten. Het onderdeel 'beleving van de relatie" omvat in het bijzonder de aspecten: overstapkosten; vertrouwen; tevredenheid met de relatie en attractiviteit. Informatie over de relatiesterkte wordt ontleend aan de 15 items van de Relationship Commitment Questionnaire (RCQ). De profielgegevens hebben betrekking op: de 'status' van de respondent (lid, ex-lid, potentieel lid); duur lidmaatschap; geslacht; leeftij; opleiding; reden voor lidmaatschap of het opzeggen daarvan.

In de Gulpener studie werden uiteindelijk 1180 adressen benaderd, waaruit 758 (merendeels mamelijke) respondenten voort kwamen $(64 \%)$. De modale leeftijdsklasse was $40-49$ jaar voor leden en potentiele leden, en 30-39 alsmede 40-49 jaar voor ex-leden. Voor alle drie de deelgroepen gold een hogere beroepsopleiding als relatief meest genoemde hoogst genoten opleiding.

Voor Gall \& Gall werden 1131 personen benaderd, hetgeen resulteerde in 500 (meest mannelijke) respondenten (44\%). De modale leeftijdsklasse was $40-49$ jaar voor zowel leden als ex-leden. Een hogere beroepsopleiding werd ook hier relatief het vaakst genoemd als hoogstgenoten opleiding. 


\section{HOOFDSTUK 6: ANALYSE VAN GEGEVENS}

Only by beginning to monitor and measure the relationships a fwm has with its customers can it begin to take charge of them."

Czopiel (1990, p. 314)

\subsection{INLEIDING}

In dit hoofdstuk zullen de resulaten wan ons onderzoek gevresenteerd worden. In hoofdstuk 5 werd al aangegeven dat het wenselijk is dat de onderzoeksnesultaicn extrapoleerbaar zijn nat andere sinuaties (externe validiteit). Door het onderzoek in verschillende siruaties toe re passen ('multiple sudy' onderzoeksbenadering), wordi cen indruk werkwegen van de externe waliheit van de onderzoeksresultaten. Ons onderzoek heeft platsgevonden onder leden en net-leden wan her Gulpener Biergilde enerzijds en wan het Gall \& Gall wijharmondersprogramma anderzijds.

De reden om onderzoek uit te voeren onder zowel leden als nie-leden (multiple sample' onderzoeksbenaderingy heeft te maken met de wens spreiding in de waarden wan de variabele relatiesterkte aan te treffen. Door leden en niel-leden wan eenzelfde hlantenclub in het onderzoek mee te nemen, wordt een wheer gedfferthtieerd beeld verkregen. Natumate het te testen meetinstrument duideliker een onderscheid kan maken tussen leden en niet-leden wan de klantenclub kan het als meer (intern) walide beschouwd worden.

Consequentie wan de gehanteerde 'multiple study, multiple sample" ondexoeksbenadering is dat er thee witgebreide en qua structuar identieke beschrijwngen worden gegeven: per studie worden de voornaamste uitkonsten besproken, te beginnen met de Gulpener siadie (96.2) gevolgd door de Gall \& Gall studie (\$6.3). Voor beide studies komen de wolgende aspecten aan de orde. Eerst zullen de dimensies van de Relatiepenceptie en Loyaliteimatrix (RLM) ingevuld worden. Voor de gedragsdimensie gebeurt dat op basis van een maatraf noor lovalirow. De belevingsdimensie wordt ingewald op basis van onze madrstaf wor relatiestevkte. Vervolgens wonden beide dimensies per deelgroep gecombineerd tot de Relwieperceptre en Loyatiteimatrix (RLM) en word aangeroond dat een verdergaande segmentatie op basis van

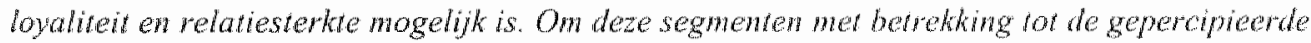
relatiesterkie te kunen beinwloeden, diem inzich verkegen to worden in de factoren die retatiesterke werklaren. Per deelgroep word daarom onderzocht aan de hand van welke factoren relatiesterkte verklact kan worden. Het hoofdstuk wordt afgesloten met conchusies ten anzien van onze hypothesen $(96.4)$.

\subsection{RESULTATEN GULPENER STUDIE}

\subsubsection{INLEIDING}

In $\$ 6.2$ worden de resultaten van de Gulpener studie weergegeven. Deze studie Kent dric geledingen: leden, ex-leden en potentiele leden wan het Gulpener Biergilde. De resultaten zullen 
voor de drie steckproeven afzonderlijk gepresenteerd worden. Eerst zal invulling gegegen worden aan de gedragsdimensie van het RLM-model (\$6.2.2). Vervolgens zal de belevingsdimensie invulling krijgen. Daar dit gebeurt aan de hand van ons meetinstrument voor relatiesterkte, de relationship commiment questionnaire (RCQ), zal ook stigestaan worden bij de validitent en betrouwbaarheid van dit meetinstrument $(\$ 6.2 .3)$. Nadat beide dimensies afzonderljk zijn besproken, wordt in \$6.2.4 het RLM-model ingevuld. In $\$ 6.2 .5$ wordt relatiesterkte gebruikt als afhankelijke variabele in het model dat gepresenteerd werd in $\$ 4.4$.

\subsubsection{LOYALITET}

Loyaliteit wordt door ons gedefinieerd in termen van feitelijke loyaliteit wan de afnemer aan de aambieder en betreft aspecten van het koopgedrag. Het onderdeel 'transactie-informatie' van de gebruikte vragenljist omvat informatie ten aanzien van het feitelijk koopgedrag (zie tabel 6.1).

In het algemeen kan worden vastgesteld dat leden aangaande het koopgedrag significant positiever scoren dan potentiele leden en ex-leden'. De scores van potentiele leden verschillen niet significant van die van ex-leden. Leden van het Gulpener Biergilde onderscheiden zich met hun koopgedrag dus in positieve zin van niet-leden. In vergelijking met niet-leden:

- hebben leden korter geleden voor het laatst Gulpener bier gekocht;

- kopen leden vaker Gulpener bier; en,

- besteden leden gemiddeld per maand meer aan Gulpener bier.

Uit de verkregen variabelen werd een nieuwe variabele samengesteld: RFM. RFM is een compilatie van de vragen 5 (Recency), 6 (Frequency) en 8 (Monetary value). In het algemeen wordt verondersteld dat de bedrijfseconomische waarde van een afnemer voor de aanbieder groler is naarmate de recency relatief korter is en de frequency en monetary value relatief groter zijn. Deze waarde wordt uitgedrukt in een score, die wordt gevormd door de waarden van de drie RFM-variabelen bij elkaar op te tellen². Meestal wordt er tevens een gewichtsverdeling toegepast. Een veel gebruikte gewichtsverdeling is: recency .5; frequency .35; monetary value .15 (Katzenstein en Sachs, 1992; De Pelsmacker en Van Kenhove, 1994). Daar dit RFM-model geschikt is voor produkten of diensten die herhaaldelijk worden aangekocht, bestaat er voor ons geen directe aanleiding hiervan af te wijken. Overeenkomstig de resultaten wan de afzonderijke variabelen is de RIM-warde voor leden significant hoger dan die voor niet-leden (ex-leden en potentiële leden, zie tabel 6.1 ).

\footnotetext{
I Zie voor de betekenis van de scotes de gebruikte vragenlijst, opgenomen in bijlage 1. Daar waar van toepassing, zijn in de vragenlijst bij de items de antwoordmogelijkheden en hun corresponderende scores opgenomen.

2Om overgewicht van de monetary value (de besteding per maand in guldens) te voorkomen, zijn de bestedingen gehercodeerd tot vijf klassen, en wel als volgt:

bestedingen van 1 tol en met 10 gulden: waarde $=1$;

bestedingen van 11 tot en met 20 gulden: waarde $=2$;

bestedingen wan 21 tot en met 30 gulden: warde $=3$;

bestedingen van 31 tot en met 40 gulden: waarde $=4$;

bestedingen van 41 gulden of meer: waarde $=5$.
} 
Tabel 6.1 Transactie-informatie: feitelijk koopgedrag

\begin{tabular}{|c|c|c|c|c|c|c|c|c|c|}
\hline \multirow{2}{*}{$\begin{array}{l}\text { Wrang- } \\
\text { nr. }\end{array}$} & \multirow[t]{2}{*}{ Onschringng } & \multirow[t]{2}{*}{ Schaal } & \multirow{2}{*}{$\frac{\text { Leder }}{\text { (d) }}$} & \multirow{2}{*}{$\frac{\begin{array}{l}\text { Porentigle } \\
\text { Leden }\end{array}}{(2)}$} & \multirow{2}{*}{$\frac{\text { Lux }}{\text { Leden }}$} & \multicolumn{4}{|c|}{ Sigmificantie-niveats ${ }^{3}$} \\
\hline & & & & & & $(1):(2):(3)$ & $(1) \cdot(2)$ & $(1):(3)$ & $(2) \cdot(3)$ \\
\hline 5 & $\begin{array}{l}\text { Recentheid batste } \\
\text { aankoop }\end{array}$ & 0 & $\begin{array}{l}\mathrm{MO}=5 \\
\mathrm{ME}=4\end{array}$ & $\begin{array}{l}\mathrm{MO}=1 \\
\mathrm{ME}=3\end{array}$ & $\begin{array}{l}M O=1 \\
M E=2\end{array}$ & $* *$ & $*$ & $*$ & - \\
\hline 6 & Frequentie aankopen & 0 & $\begin{array}{l}\mathrm{MO}=3 \\
\mathrm{ME}=3\end{array}$ & $\begin{array}{l}\mathrm{MO}=3 \\
\mathrm{ME}=3\end{array}$ & $\begin{array}{l}\mathrm{MO}=1 \\
\mathrm{MH}=2.5\end{array}$ & $* *$ & $* *$ & * * * * & - \\
\hline 8 & $\begin{array}{l}\text { Besteding per maand } \\
\text { in guldens }\end{array}$ & UR & 36.75 & 22.81 & 24.35 & ***; & 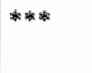 & $* *$ & . \\
\hline- & $\begin{array}{l}\text { Recency, Frequency, } \\
\text { Monetary value } \\
\text { (RFM) }\end{array}$ & $0 / 1$ & 3.38 & 2.83 & 2.65 & $* * *$ & *w口 & 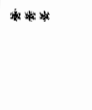 & - \\
\hline
\end{tabular}

\section{Toelichting:}

In deze tabel en in de komende tabellen komt onder 'schaal' een anutal afkortingen voor: $\mathrm{D}=$ dichotome scheal: $\mathrm{N}=$ nominale schaal; $\mathrm{O}=$ ordinale schaal; $\mathrm{OI}=$ een ordinale schaal die als inlervalschaal behamdeld wordt; $\mathrm{I} / \mathrm{R}$ = een interval- danwel ratioschaal. Verder kan in de tabellen nog een awntall afkortingen voorkomen. MO staat voor modus, en MlE voor mediaan.

(1):(2) duidt op een vergelijking van de deelgroep leden (1) met de deelgroep potentiête leden (2) betreffende een bepaalde vraag of variabele.

\subsubsection{RELATIEPERCEPTIE}

\section{De Relationship Commitment Questionnaire (RCQ): betrouwbaarheid}

De Relationship Commitment Questionnaire is opgebouwd uit 15 items. Tabel 6.2 geeft de gemiddelde scores van elk van de vijftien items weer. De betrouwbaarheid, in termen van interne consistentie (Cronbach alpha), over alle 15 items van de RCQ is .83.

\footnotetext{
niet significant ( $\mathrm{n} . \mathrm{s}_{\mathrm{n}}$ ): $p>0.05$; significant $\left({ }^{*}\right)$ : $0.05 \geq p>0.01$ zeer significant (**): $0.01 \geq p>0.001$ uitermate significant (***): $p \leq 0.001$.
}

${ }^{3}$ Bij het analyseren is uitgegaan van de volgende significantie niveaus:

Er is standaard gebruik gemaakt van tweezijdige toetsen. Voor het vergelijken van de deelgroepen (leden, ex-leden, potentiële leden) is gebruik gemaakt wan meerdere toetsen, afhankelijk van het aantal steekproeven en het schaaltype. De bestanden van leden, ex-leden en potentiële leden zijn ongerelateerd. Bij het vergelijken van ongerelateerde steekproeven is in geval van een nominaal geschaalde wariabele gebruik gemaakt van de Chi-kwadraattoets. Bij een ordinaal geschaalde variabele is in geval wan twee ongerelateerde steekproeven gebruik gemaakt van de Mann-Whitneyloets, en in geval van meer dan twee ongerelaterde steekproeven is gebruik gemaakt van de Kruskal-Wallistoets. Ordinaal geschaalde variabelen die als interval geschaalde variabelen beschouwd en behandeld kumen worden, zijn onderworpen aan de th-toets en ANOVA voor twee respectievelijk meer dan twee ongerelateerde steekproeven. Interval en ratio-geschaalde variabelen werden eveneens aan ANOVA en t-toets onderwotpen. 


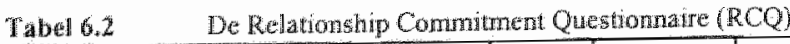

\begin{tabular}{|c|c|c|c|c|c|c|c|c|c|}
\hline \multirow{2}{*}{$\begin{array}{l}\text { Wrago } \\
\text { nir. }\end{array}$} & \multirow[t]{2}{*}{ Omschrijuing } & \multirow[t]{2}{*}{ Schatal } & \multirow{2}{*}{$\frac{\text { Leden }}{(1)}$} & \multirow{2}{*}{$\begin{array}{l}\text { Potentide } \\
\text { Leden }\end{array}$} & \multirow{2}{*}{$\begin{array}{l}\text { Ex- } \\
\text { Leden }\end{array}$} & \multicolumn{4}{|c|}{ Significantio-niveras } \\
\hline & & & & & & $(1) \cdot(2) \cdot(3)$ & (1) $:(2)$ & $(n) \cdot a)$ & $(2) \cdot(9)$ \\
\hline 49 & Extra moeite & on & 3.51 & 2.96 & 2.97 & $* *$ & $* * *$ & \#***4; & - \\
\hline 50 & Org. aanbevelen & on & 3.69 & 3.47 & 3.45 & $*$ & - & $*$ & - \\
\hline 51 & Weing loyaliteit & $\% / 1$ & 3.43 & 3.13 & 3.31 & $*$ & *** & - & - \\
\hline 52 & Prijsvethoging $10 \%$ & O/1 & 3.46 & 3.10 & 3.07 & $* 4 *$ & $\approx *$ & 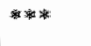 & - \\
\hline 53 & Waarden en nomen & OI & 3.70 & 3.37 & 3.35 & ** & $*$ & * sot & - \\
\hline 54 & Trots vertellen & On & 3.37 & 2.95 & 2.79 & *** & +2 & $* * *$ & 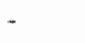 \\
\hline 55 & Ander kopen & $\mathrm{O} / \mathrm{H}$ & 3.18 & 2.88 & 2.76 & $* * *$ & $*$ & 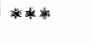 & - \\
\hline 56 & Hemalingsaankopen & on & 3.56 & 3.44 & 3.36 & - & - & $*$ & - \\
\hline 57 & Weinig nodig switch & o/ & 3.52 & 3.38 & 3.30 & - & - & $*$ & - \\
\hline 58 & Blig met kauze & oll & 3.56 & 3.20 & 3.01 & 事事 & $* * *$ & 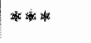 & - \\
\hline 59 & Niei veel woorded & OII & 3.09 & 3.14 & 286 & - & - & - & * \\
\hline 60 & Moeite met beleid. & o/l & 3.73 & 3.82 & 3.68 & - & - & - & - \\
\hline 61 & Geef om lot & $\mathrm{O} / \mathrm{I}$ & 3.58 & 3.21 & 3.09 & $* * *$ & ** & $* * *$ & - \\
\hline 62 & Beste alternatief & OII & 3.60 & 3.3 .8 & 3.05 & $* *$ & $*$ & *** & $* *$ \\
\hline 63 & Verkeerde beslissing & O/L & 4.05 & 4.13 & 4.13 & - & - & - & - \\
\hline
\end{tabular}

Opgemerkt wordt echter dat zes items (nl.: 51, 52, 57, 59, 60 en 63) weliswaar een positieve, maar lage (kleiner dan .40) item-totaalcorrelatie vertonen (Churchill, 1995). Het weglaten van deze zes items leidt tot een verkorte $\mathrm{RCQ}$ bestaande uit negen items. De betrouwbarheid (Cronbach alpha) van deze RCQ is 87 . Daarbij zijn alle item-total correlaties positiof en groter dan .40 . Dit duidt er op dat deze verkorte, negen item schaal homogener is dan de luigebreide, 15 item schal met betrekking tot het construct (relatiesterkte) dat zij meten. Een verkorte RCQ geniet op basis wan Cronbach alpha analyse en item-totaalcorrelatie de voorkeur en zal derhalve als uitgangspunt worden genomen voor verdere analyses ${ }^{4}$. Bij die analyses

"Een verkorte meetschanlquestionnaire word rok in de organisatieliteratuur regelmatig gebruikt, met name in situaties warin de lengte van de vragenligst een aandachtspunt is (Mowday et al., 1979; 1982). Het betreft dan veelal ten meetsehaal die bestat ut de negen positief geformuleerde items, dat als een acceptabel substihut beschouwd wordt voor de uigebreide schaal. Ondanks dat de inteme consistentie voor deze verkorte versie in het allgemeen overeenkomt met die van de volledige meetschaal, raden Mowday et al. $(1979 ; 1982)$ aan enige voorzichtigheid in acht te nemen bij het samenstellen van een dergelijke verkorte versic atangezien enkele van de negatief geformuleerde items een hogere itemtotalscore kunnen vertonen dan verscheidene positief gefonmuleerde items (zoals ook in ons eigen onderzoek het geval blijkt te zijn). Zij adwiseren dan ook, daar waar het mogelijk is, toch de volledige 
wordt RC als een unidimensionele variabele beschouwd en behandeld: er zal een index voor $\mathrm{RC}$ berekend worden door de scores van de negen items op te tellen en de som te delen door negen ${ }^{5}$.

Op basis van deze negen items van de RCQ kan geconcludeerd worden dat leden significant verschillen van potentiële leden en/of van ex-leden en dat leden een sterkere relatie percipieren dan niet-leden (zie tabel 6.2). Dat houdt in dat consumenten (i.c. leden) die een verhoudingsgewijs (i.c. ten opzichte van potentiele leden en/of ex-leden) sterke relatie ervaren:

1. meer bereid zijn extra moeite te doen om bier van Gulpener te kunnen kopen;

2. Gulpener vaker/meer bij vrienden aanprijzen als een organisatie die prima bien brouwt;

3. een sterkere overeenkomst zien tussen de eigen waarden en nomen en die van Gulpener;

4. er trots op zijn anderen te kunnen vertellen dat zij bier van Gulpener kopen;

5. minder makkelijk bier van een andere bierbrouwer kopen;

6. eerder tot herthalingsaankopen zullen overgaan;

7. meer blij zijn Gulpener verkozen te hebben boven andere browwerijen;

8. meer begaan zijn met het lot wan Gulpener; en,

9. in grotere mate Gulpener als het beste alternatief zien.

In tabell 6.3 worden de waarden voor relatiesterkte (RC) weergegeven. $\mathrm{RC}$ is het ongewogen gemiddelde van de scores van de negen items van de RCQ. Vastgesteld kan worden dat leden significant hoger scoren dan niet-leden. Onder de niet-leden is er geen significant verschil tusser ex-leden en potentiële leden, ondanks dat potentiële Jeden licht positiever scoren dan exleden. Kortom, ten opzichte van ex-leden en potentiële leden geldt voor leden dat zij een sterkere relatie met de aanbieder percipiëren.

Tabel 6.3 Relationship Commitment (RC)

\begin{tabular}{|c|c|c|c|c|c|c|c|c|}
\hline Variabele & Schaal & Leden & Potentiele Ledent & Ex-Leden & Significam & -miveaus & & \\
\hline & & (l) & (2) & (3) & $(1) \cdot(2):(3)$ & $(1) \cdot(2)$ & $(1) \cdot(3)$ & $(2):(3)$ \\
\hline $\mathrm{RC}$ & O/I & 3.55 & 3.21 & 3.12 & 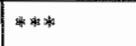 & **** & 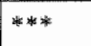 & $1-$ \\
\hline
\end{tabular}

\section{${ }^{4}($...verwolg)}

meetschal in het onderzoek op te nemen. De negatief geformuleerde items worden dan in het bijzonder opgenomen om een mogelijke tendens in antwoorden te voorkomen. Deze adviezen hebben wij gevolgd: de wolledige meetschaal is in hel onderzoek opgenomen, met zowel posilief als negatief geformuleerde items. Dit latste, kunstmatige onderscheid is vervolgens echter niet als uitgangspunt genomen om tot een verkorte meetschaal te komen. Onze selectie van items is gebaseerd op de Cronback alpha-warde en op item analyse.

${ }^{5}$ Ook in de organisatieliteratuur wordt een index voor (organizational) commitment berekend door de scores van de afzonderlijke items bij elkaar op te tellen en de som vervolgens te delen door het aantal items. Dit impliceert dat $O C$ als een unidimensionele variabele beschouwd en behandeld wordt. hetgeen weelal ondersteund wordt door de resultaten van factor-analyses: deze duiden in het algemeen op een érn-factor oplossing (Mowday et al., 1979; Bearden et al., 1993). Ook Morgan en Hunt (1994) en Kelley en Davis (1994), die de OCQ gebruiken als basis voor het meien van relationship commitment (RC), beschouwen de items van hun meetschaal als relatief homogeen en onderscheiden geen nadere dimensies. 
Om meer inzicht te krijgen in de samenstelling van de variabele relatiesterkte (RC), word de RCQ nader onderzocht met behulp wan Principale Componenten Analyse. Het betreft een Principale Componenten Analyse met warimax rotatie waarbij als selectie criterium uitgegaan wordt van het gebruikelijke criterium dat de Eigenwaarde groter dan of gelijk aan 1 is (Kaiser, 1958). Principale Componenten Analyse uitgevoerd op de RCQ llevert één factor op. In tabel 6.4 zijn de factorladingen, die boven .45 liggen, weergegeven, alsmede de Eigenwaarde en het percentage van de variantie dat door deze factor verklaard wordt. De resultaten van de Principale Componenten Analyse bevestigen dat de negen jtems van de RCQ relatief homogeen zijn en deel uitmaken van een unidimensioneel construct, i.c. RC.

Tabel 6.4
\begin{tabular}{|l|l|c|}
\hline Vraagnr: & \multicolumn{1}{|c|}{ Omincipale Componenten Analyse op de negen items wan de RC } & Factorladingen \\
\hline 58 & Blij met keuze & .83 \\
62 & Beste alternatief & .77 \\
54 & Trots vertellen & .77 \\
49 & Extrat moeite & .74 \\
50 & Organisatie aanbevelen & .70 \\
53 & Waarden en nornen & .68 \\
61 & Geeft om lot & .67 \\
55 & Ander kopen & .55 \\
56 & Herhalingsaankopen & .52 \\
\hline Variantie (\%) & 49.0 \\
Eigenwarde & 4.41 \\
\hline
\end{tabular}

\section{De Relationship Commitment Questionmaire (RCQ): validiteit}

Nadat in het voorgaande aandacht werd besteed aan de betrouwbarheid, in termen van interne consistentic ${ }_{\mathrm{s}}$ wordt hier nader ingegaan op de validiteit van het geteste meetinstrument (RCQ). De validiteit van een construct heef betrekking op de mate waarin het construct daadwerkelijk meet wat we willen of veronderstellen dat het meet (Weiers, 1984; Green et al., 1988; Kooiker en van den Heuvel, 1992; Bagozzi, 1994; De Pelsmacker en Van Kenhove, 1994; Zwart, 1994; Churchill, 1995). Er bestaan meerdere manieren om de validiteit van een construct te bepalen. Face-validity, ook wel content-validity of inhoudvaliditeit genoemd, is én aspect van validiteit (Weiers, 1984; Bagozzi, 1994; De Pelsmacker en Van Kenhove, 1994). Daarover is reeds verslag gedaan in de hoofdstukken 4 respectievelijk 5 (met name \$5.5). Gesteld kan worden dat er sprake is van face-validity.

Hier zal nader worden ingegaan op twee aspecten van construct validiteit, namelijk convergent validiteit en discriminant validiteit (Bagozzi, 1994). Bieide vormen wan validiteit zijn vast te stellen via het analyseren van de correlatie-coëfficiënten tussen twee of meer constructen (Campbell en Fiske, 1959). 
Convergent-validity komt in een hoge correlatie-coefficiènt to uitdrukking (Bagozzi, 1994). Zo mag er een sterk positief verband verondersteld worden mssen RC en hel alternatieve commitment construct.

In geval van discriminant-validity dient er geen all te hoge correlatie tussen in principe verschillende constructen te worden aangetroffen (Bagozzi, 1994). Overstapkosten, attractiviteit, tevredenheid en vertrouwen zijn constructen die verschillen van RC. Hier zal dan ook van lagere correlatie-coefficiënten sprake dienen te zijn dan in geval van convergentvalidiry

Het onderdeel 'beleving van de relatie' van onze vragenlijst verschaft (zoals in $\$ 5.4 .2$ aangegeven) informatie ten aanzien van: overstapkosten, wertrouwen, tevredenheid, attractiviteit en het altematieve commitment construct. Met uitzondering van tevredenheid en attractiviteit zijn de variabelen uit meerdere ttems samengesteld. De Cronbach alpha coefficient bedraagt voor de gepercipieerde overstapkosten .66 . Voor ventrowwen bedraagt deze .75 en voor het alternatief commitment construct.68 (zie tabel 6.5). Daar deze waarden groter zijn dan $.60 \mathrm{kan}$ gesteld worden dat de mate van betrouwbaarheid (interne consistentie) van deze drie constructen acceptabel is (Bagozzi, 1994; Malhotra, 1996). Alle items hebben een itemtotaalcorrelatie groter dan .40, zodat er geen aanleiding is items weg te laten (Churchill, 1995).

Tabel 6.5 Overzicht Cronbach alpha waarden voor de variabelen; gepercipieerde overstapkosten, vertrouwen en alternatief commitment.

\begin{tabular}{lccc}
\hline & Aantal items & Crombach alpha & "1 \\
\hline overstapkosten & 2 & .66 & 480 \\
vertrouwen & 2 & .75 & 516 \\
alternatief commitment & 4 & .68 & 500 \\
\hline
\end{tabular}

m. gantall respondenten in de analyse

Van de variabelen die uit meerdere items bestaan, zijn indices samengesteld. De indices zijn berekend door het ongewogen gemiddelde te memen van de waarden van de afzonderlijke items. Zij staan vermeld in tabel 6.6 .

Uit tabel 6.6 blijkt dat leden zich voor hogere overstapkosten geplaaist zien dan potentiele leden en ex-leden. Terwijl leden wij neutraal zijn in hun mening ten aanzien van overstapkosten, geven niet-leden aan dat het vrij gemakkelijk is de huidige band met Gulpener te verbreken en een band met een andere bierbrouwer aan te gaan.

Verder blijkt dat alle drie de deelgroepen vertrowwen hebben in Gulpener, maar leden hebben significant meer vertrouwen in Gulpener dan potentiele leden en ex-leden.

In het algemeen genomen zijn leden, potentiele leden en ex-leden in dezelfde mate teveden over Gulpener en haar produkten.

Leden hebben, in vergelijking met ex-leden, een significant positiever totaalbeeld van Gulpener, indien Gulpener vergeleken wordt met alternatieve bierproducenten. Met andere woorden: voor leden van het Gulpener Biergilde is de attractiviteit van Gulpener groter dan voor ex-leden.

Tot slot kan geconcludeerd worden dat leden zich sterker gecommitteerd woelen met de aanbieder dan ex-leden en potentiële leden. 
Tabel 6.6 Belevinge van de relatie: santengestelde variabelen

\begin{tabular}{|c|c|c|c|c|c|c|c|c|}
\hline Variabele & Sichand & Ledent & Potentidye Ledent & Ex-Ledent & Significanti & miveaus & & \\
\hline & & (1) & (2) & $(3)$ & $(1):(2):(3)$ & $(1):(2)$ & $(1):(3)$ & $(2) \cdot(3)$ \\
\hline Onerstapkosten & OI & 2.87 & 2.53 & 2.38 & $* * *$ & ** & *w* & 1. \\
\hline Vertrouwen & or & 3.97 & 3.78 & 3.71 & *** & * & $* * *$ & - \\
\hline Tevredenheid & or & 422 & 4.18 & 4.20 & - & $=$ & - & - \\
\hline Atractiviteit & o/l & 3.82 & 3.68 & 3.65 & * & - & * & . \\
\hline Alematief RC & oll & 3.55 & 3.29 & 3.28 & 秘米 & $* *$ & $* * *$ & - \\
\hline
\end{tabular}

Met behulp van deze constructen kan nu een indicatie van de convergent- en discriminant validiteit verkregen worden. In tabel 6.7 zijn de Pearson conelatie-coèfficiënten weergegeven tussen RC enerzijds en het alternatieve commitment construct, overstapkosten, attractiviteit, tevredenheid. en vertrowwen anderzijds. Nemen we deze tabel in beschouwing, dan kan vastgesteld worden dat er sprake is van convergent-validiteit. Immers, het $\mathrm{RC}$ construct correleert inderdaad sterk met het alternatieve commitment construct $(r=, 66)$. Tevens bleek uit de tabellen 6.3 en 6.6 dat RC en het alternatieve commitment construct overeenkomstige witkomsten voor de drie onderscheiden onderzoeksgroepen laten zien, in die zin dat leden significant hoger scoren dan potentiele leden en ex-leden. De correlatie tussen RC en het alternatieve commitment construct is tevens het hoogst vergeleken met de overige correlaties. Gelet op de aard van de constructen averstapkosten, attractiviteit, tevredenheid en vertrouwen en het veronderstelde verband tussen deze constructen en RC (zie figuur 4.7) mag een zekere mate van correlatie verwacht worden. Uit tabel 6.7 blijkt dat deze correlaties weliswar hoog zijn (variërend van .43 tot .56 ), echter de correlaties tussen RC enerzijds en overstapkosten, attractiviteit, tevredenheid en vertrouwen anderzijds, zijn significant lager dan $1^{6}$. Dit impliceert dat er ook sprake is van een zekere mate van discriminant-validiteit (Kumar et al., $1995 \mathrm{a} ; 1995 \mathrm{~b}$ ).

De correlatie tussen $\mathrm{RC}$ en vertrouwen is van deze laatste vier constructen het hoogst. Vertrouwen is cen variabele die veelvuldig als antecedent van commitment wordt genoemd (a.a.: Wilson, 1990; Morgan en Hunt, 1994; zie met name hoofdstuk 4). Een redelijk positief verband ligt dan ook voor de hand. Tevredenheid en RC comeleren het zwakst, hetgeen eveneens overeenstent met ons model in hoofdstuk 4, warin tevredenheid verondersteld wordt een ind frect verband met RC ta hebben (via vertrouwen).

\footnotetext{
${ }^{6}$ Hierbij is gebruik gemaakt van de 'Z-test of a cortelation coefficient' (Kanji, 1993, p. 34). Alle berekende $Z$ warden waren hoger dan de kritieke waarde van 1.96 bij een p-waarde wan 0.05 . Dit impliceert dat de correlaticoefficienten significant van de warde 1 afwijken.
} 


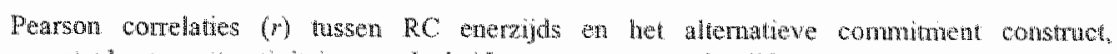
overstapkosten, attractiwiteit, tevedenhed en vortrounen anderajds

\begin{tabular}{|c|c|c|}
\hline & $r$ & $n$ \\
\hline altenatief commitument & $.66^{\text {tact }}$ & 375 \\
\hline onersiakosten & $.51+* *$ & 352 \\
\hline atroctiviteit & $48 * *$ & 375 \\
\hline terredenheid & $43 *$ & 380 \\
\hline vertrouwen & $.56 * * *$ & 378 \\
\hline
\end{tabular}

* $p<.001 ; n$ : anantal respondenten ix de analyse

Hoewel de correlatie ten behoeve van het vaststellen van convergent-validiteit hoger is dan de correlaties ten behoeve van het vaststellen van discriminant validiteit, en de bevindingen ten aanzien van discriminant validiteit weliswaar acceptabel zijn, is de mate van discriminant validiteit niet geheel overtuigend. Via confirmatorische factoranalyse (CFA) op de geselecteerde items van de multi-item constructen 'RC', "gepercipieerde overstapkosten" en 'vertrouwen' kan eveneens een indruk verkregen worden of genoemde constructen van elkaur onafhankelijke concepten zijn (Hair et al, 1995). De CFA werd uitgevoerd met LISREL 7.20 en resulteerde in een Chi-kwadraat van 126.59 (62 vrijheidsgraden; $p<.001 ; n=3.48$ ) en een 'adjusted' Chi-kwadraat (Chi-kwadraat/vrijheidsgraden) van 2.04. De Goodness of Fii index (GFI) bedraagt .95, de Adjusted GFI (AGFI) is .92 en de Root Mean Square Residual (RMSR) bedraagt .04. Alle factorladingen zijn zeer significant (minimum t-waarde is 8.98) en overtroffen het 40 niveau dat algemeen als betekenisvol word beschouwd in factoranalyse (Ford et al., 1986). Deze resultaten duiden er op dat de discriminant validiteit goed is: de constructen zijn wezenlijk verschillend.

Geconcludeerd wordt dat de mate van betrouwbarheid, inhoudwaliditeit en convergent-validiteit van de RCQ voldoende is, terwijl de mate van discrminant-validiteit goed is. Daamee kan hypothese 1 voor de Gulpener studie niet verworpen worden: de relationship commilment questionnaire (RCQ) is een betroubare en valide meetschaal voor het vaststellen van de sterkte van relaties tussen een aanbieder en zjin eindafnemers, i.c. consumenten.

\subsubsection{HET RLM-MODEL VOOR DE GULPENER STUDE}

In de vorige paragraaf is gebleken dat de relationship commiment questionatire (RCQ) een betrouwbare en valide meetschaal is voor het vaststellen van de sterkte van relaties (RC) ussen een aanbieder en zijn eindafnemers. Tot nog toe was echter sprake van op woorhand bekende deelgroepen waarvan verwacht werd dat zij zouden verschillen in relatiesterke. De RCQ heef die verschillen gekwantificeerd en expliciet gemaakt. Nu de RCQ als een betrouwbare en valide meetschal geldt, is het juist interessant $R C$ als segmentatievariabele toe te passen in situaties warin niet op voorhand segmenten te onderscheiden zijn die verschillen in relatiesterkte. Daartoe zal vervolgens per deelgroep een RLM-model opgesteld worden en de vier segnenten daarbinnen nader geanalyseerd worden. Doel daarvan is dus te onderzoeken of de segmenten binnen elke deelgroep significante verschillen vertonen voor beide dimensies (RFM en in het bijzonder RC) en dus op basis van deze dimensies eenduidig beschreven kunnen worden. 
Voorzover dat het geval is rechtvaardigt dat een specifieke benadering van deze segmenten en is er een dieper inzicht verkregen in de samenstelling var de deelgroep. Er zal in dat geval dan ook gekeken worden naar mogelijkheden om op die verschillen in te spelen en verschuivingen aan te brengen binnen de RLM-matrix. Dit gebeurt met name door te kijken naar het verschil in huidig en gewenst relatieniveau enerzijds (op basis van de vragen 33 respectievelijk 35 van de vragenlijst) en naar de procentuele bestedingen van de klant an Gulpener bier (het zogenaamde 'customer share' of klantaandeel) anderzijds (op basis van vraag 9). Het verschil in huidig en gewenst relatieniveau biedt nader inzicht in de mogelijkheid en wenselijkheid de relatie te intensiveren en dus RC te beinvloeden. In hoofdstuk 2 werd reeds aangegeven dat het accent in relaticmarketing meer ligt op klantaandeel dam op marktaandeel. Het huidige klantaandeel geeft aan of er via het betnvloeden van het koopgedrag nog mogelijkheden zijn dit aandeel in de tockomst uit te breiden.

Als scheidingscriterium woor zowel RC als RFM, teneinde de vier segmenten te kumen onderscheiden en vervolgens te analyseren, is de neutrale waarde 3 genomen 7 . Tabel 6.8 geeft per deelgroep de onvang van de vier segmenten weer.

Gelet op de diversiteit in de samenstelling van de deelgroepen, lijkt het zinvol naast de 'status" van de respondent (lid, ex-lid, potentieel $\|$ id) ook het gegeven of iemand als kennis, functionalist, sympathisant of als vriend aangemerkt kan worden als criterium te nemen voor een specifieke klantbenadering. Aansłuitend zal dan ook elk van de deelgroepen afzonderlijk nader in beschouwing genomen worden, te beginnen met de leden, vervolgens de ex-leden en tot slot de potentiele leden van het Gulpener Biergilde.

In totaal zullen 298 respondenten in deze analyses worden meegenomen ${ }^{8}$. In bijlage 6 is een overzicht opgenomen warin de respondenten die in de analyses zijn meegenomen op meerdere verschillende aspecten vergeleken worden met respondenten die niet in de analyses zijn meegenomen. Uit deze analyses blijkt dat er nauwelijks verschillen bestaan tussen deze twee response-groepen.

Te keuze voor een vaste warde als scheidingscriterium binnen het RLM-model heeft als voordeel dat het vergelijken van segmenten, zowel tussen deelgroepen ais in de tijd, beter mogelijk wordt. Verschilten en wijzigingen, bijvoorbeeld in de positie wan de segmenten binnen het RLM-model of in de omvang van de segmenten, worden duidelijker zichtbaar.

Deze respondenten hebben alle 12 items beantwoord. RC is inmers opgebouwd uit 9 en RFM uit 3 items. Hat aantal respondenten ligt dam ook lager dan het aantal respondenten dat alleen op de 3 items van RFM, respectievelijk op de 9 items van RC geantwoord heeft. De aanwezigheid van item nonresponse (Churchill, 1995) speelt hier dus een grote rol bij het aantal respondenten dat in de analyses worlt meegenonen. Besloten is on de 'missing values' hiet te verwangen door de gemiddelde waarde voor het betreffende item op basis van zij die wel respondeerden. De nadere segmentatie die wij willen aanbrengen naar kenmissen, sympathisanten, vrienden en functionalisten dient namelijk plaats te vinden op basis van de feitelijke warden voor RFM en RC voor de betreffende respondent en niet op basis wan een gemiddelde warde voor de hele deelgroep (leden, ex-leden of potentiële leden). 
Tabel 6.8 Verdeling wan leden, ex-leden en potentiele leden wan het Gulpener Biergilde over de vier cellen van het RLM-model

\begin{tabular}{|l|c|c|c|c|c|}
\hline & Kennissen & Functionalisten & Sympathisanten & Fintenden & Total \\
\hline Leden & $14(9 \%)$ & $14(9 \%)$ & $34(23 \%)$ & $87(59 \%)$ & $149(100 \%)$ \\
Ex-ledten & $31(30 \%)$ & $11(11 \%)$ & $27(27 \%)$ & $33(32 \%)$ & $102(100 \%)$ \\
Potentiële leden & $7(15 \%)$ & $4(9 \%)$ & $14(30 \%)$ & $22(46 \%)$ & $47(100 \%)$ \\
\hline Total & 52 & 29 & 75 & 142 & $298(100 \%)$ \\
\hline
\end{tabular}

Figuur 6.1 toont het RLM-model voor leden. De omvang van de cirkels vertegenwoordigt de omvang van het betreffende segment binnen de deelgroep van leden. Er is sprake van een positief verband tussen $\mathrm{RC}$ en $\mathrm{RFM}$ voor leden (Chi-kwadrat $=4.04 ; p=.04$ ). Het verband is echter als zeer zwak aan te merken, daar zowel Phi als de contingentiecoëfficiënt C .16 bedraagt $^{9}$ (De Pelsmacker en Van Kenhove, 1994; Churchill, 1995).

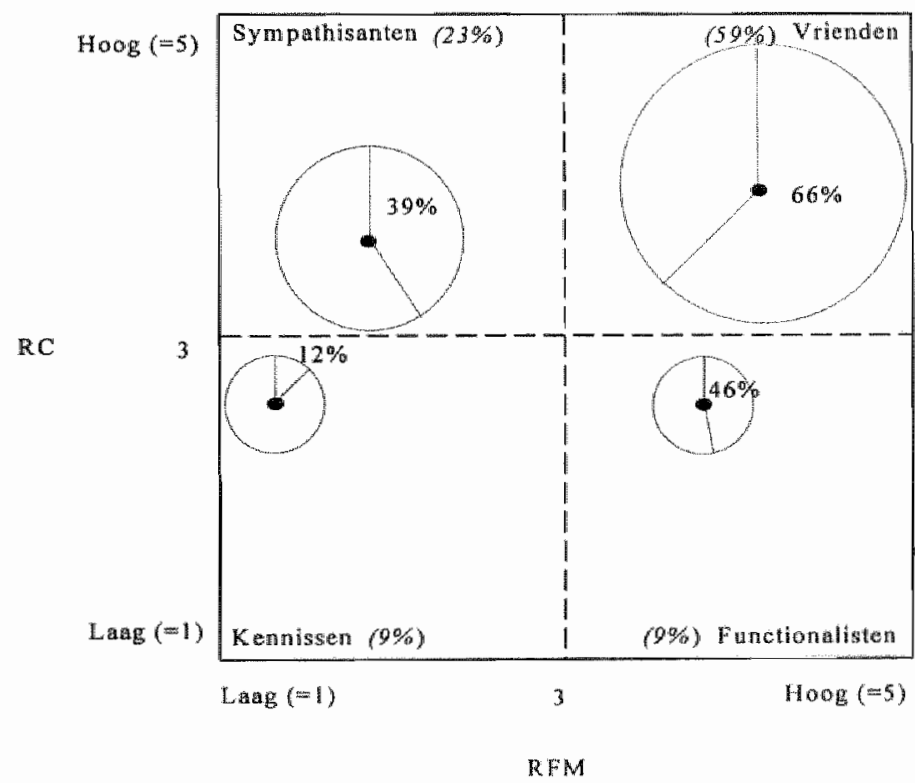

Figuur 6.1 Het RLM-model voor leden van het Gulpener Biergilde

Tabel 6.9 geeft de gemiddelde waarden voor RFM respectievelijk RC van de vier segmenten. Ook wordt aangegeven of de segmenten significant van elkaar verschillen en dus eenduidig

\footnotetext{
${ }^{9}$ De contingentiecoëficiènt $\mathrm{C}$ alsmede Phi zijn maatstaven woor de sterkte van het verband. De contingentiecoëfficiënt $\mathrm{C}$ kan in gewal van een $2 \times 2$ tabel een maximale waarde van .71 aannemen, hetgeen duidt op een witermate sterk verband. Phi kan een waarde tussen -1 en +1 aannemen, warbij de ankerpunten - 1 en +1 een uitermate sterk verband vertegenwoordigen.
} 
kunnen worden beschreven op basis van RC en RFM. Het bijkt dat de respondenten die tot hetzij het segment sympathisanten, hetzij het segment vrienden behoren een significant sterkere relatie percipieren dan respondenten die tot hetzij het segment kennissen, hetzij het segment functionalisten behoren. Voor de economisch waardevolle segmenten vienden en functionalisten geldt dat zij een significant hogere RFM-waarde hebben dan de segmenten sympathisanten en kennissen. RC en RFM hebben dus een sterk onderscheidend vermogen.

"If abul 6.9 Waarden woor RC, RFM en worgeluking wen segmenten voor leden

\begin{tabular}{|c|c|c|c|c|c|c|}
\hline gegment & RC: & $R B W$ & Keninissen: & Functonatston & Sympathicanten & Iriendsw \\
\hline Kenwistont & 2.68 & 1.32 & - & 皮4 & * & * \\
\hline Furchorialister & 2.67 & 3.78 & n.s. & - & 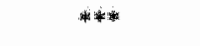 & n.s. \\
\hline Sythpalhowathent & 3.56 & 1.89 & *** & W & $\ldots$ & * \\
\hline Friendent & 3.90 & 4.24 & **** & 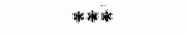 & 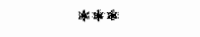 & - \\
\hline
\end{tabular}

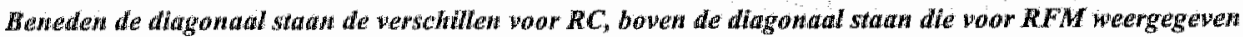
nus: niver significant

Tabel 6.10 geeft inzicht in hoeveel procent van de bieraankopen gemiddeld genomen door de leden-respondenten wan de vier segmenten aan Gulpener bier besteed wordt. Daarnaast geeft tabel 6.10 ook aan of er significante verschillen bestaan tussen de segmenten voor dit "Wlantaandeel". Het klantaandeel van vrienden blijkt significant groter te zijn dan dat van sympathisanten en kennissen. Daarnaast besteden de functionalisten procentueel ook significant meer dan kemissen.

Tabel 6.10 Procentuele bestedingen en vergelijking wan segmenten voor leden

\begin{tabular}{|c|c|c|c|c|c|}
\hline Segritent & Bestedingen in $\%$ & Kenmissen & Functionalisten & Sympathisantert & Vrienden \\
\hline Kenalszenn & 12 & - & & & \\
\hline Fanctionalleten & 46 & $*$ & $=$ & & \\
\hline Symphowhowen & 39 & M.S. & $\mathbf{n}_{\text {s. }}$ & - & \\
\hline Menden & 66 & 事 & n.s. & $* * *$ & - \\
\hline
\end{tabular}

Mas o mien significant

Wordt naa de mogeljkheid gekeken on de relatie te versterken dan kan het verschil tussen huidige (vraag/item 33) en gewenste relatie (vraag/item 35) behulpzaam zijn. Voor elk van de vier segmenten werd het lowidige relatieniveau vergeleken met het gewenste relatieniveau. Dearuit bleek dat voor geen van de segmenten een significant verschil kon worden aangetoond tussen huidig en gewenst relatieniveau. Leden, die over het algemeen een sterke relatie percipiëren ( $82 \%$ behoort tot het segment sympathisanten of vrienden; zie tabel 6.8 ), vinden het huidige relatieniveau blijkbaar voldoende.

Figun 6.2 toont het RLM-model voor ex-leden. De cirkelomtrek vertegenwoordigt weer de omvang van het betreffende segment binnen deze deelgroep. Ook hier is sprake van een positief 
verband tussen $\mathrm{RC}$ en $\mathrm{RFM}$ (Chi-kwadrat $=7.23 ; p=.007$ ). Het werband is echter als 2 wak aan te merken, daar de contingentiecoefficient $C .26$ bedraagt. Phi bedraagt 27.

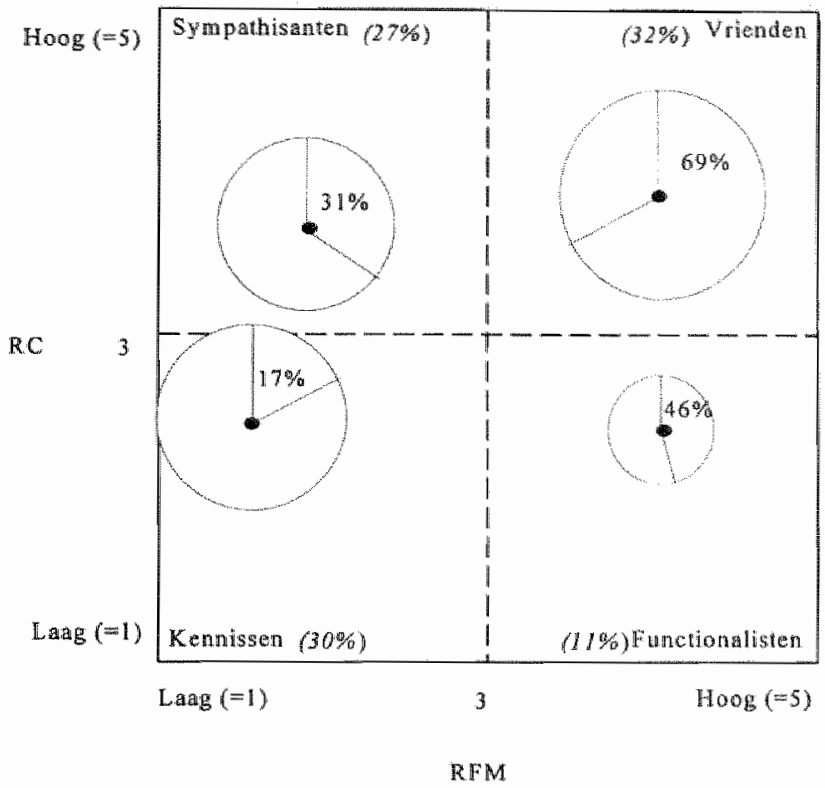

Figuur 6.2 Het RLM-model voor ex-leden van het Gulpener Biergilde

Tabel 6.11 geeft de gemiddelde waarden voor RFM respectievelijk RC van de vier segmenten, alsmede of de segmenten significant van elkaar verschillen en dus eenduidig kunnen worden beschreven op basis van RC en RFM. Ook hier blijkt dat de respondenten die tot hetzij het segment sympathisanten hetzij het segment vrienden behoren een significant sterkere relatie percipiëren dan respondenten die tot hetzij het segment kennissen hetzij het segment functionalisten behoren. Voor de economisch waardevolle segmenten vrienden en functionalisten geldt dat zij een significant hogere RFM-waarde hebben dan de segmenten sympathisanten en kennissen. RC en RFM hebben dus ook in geval van ex-leden een sterk onderscheidend vermogen.

Tabel 6.11 Warden voor RC, RFM en vergelijking van segmenten voor ex leden

\begin{tabular}{|c|c|c|c|c|c|c|}
\hline Segnent & $R C$ & RHA & Kennissen & Functownlisten & Symparkisanent & Vriendan \\
\hline Kewnissen & 2.58 & 1.60 & - & 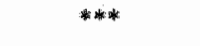 & Mi. 5. & *的的 \\
\hline Functionalisten & 2.48 & 4.15 & ก. & $=$ & 皮 & $n s$. \\
\hline Sympathisantew & 3.68 & 1.85 & $* * *$ & * & - & 4 \\
\hline Vriendest & 3,80 & 4.17 & $* *$ & 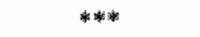 & a... & - \\
\hline
\end{tabular}

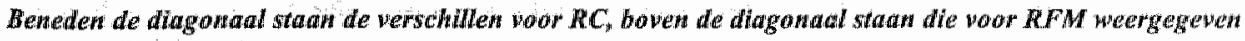
n. S. vilut significant 
Tabel 6.12 geeft aan hoeveel procent van de bieraankopen gemiddeld genomen door de respondenten van de vier segmenten aan Gulpener bier besteed wordt. Tevens vermeldt tabel 6.12 of er significante verschillen bestaan tussen de segmenten voor dit "klantaandeel". De verschillen in klantaandeel vertonen eenzelfde patroon als bij de leden is waargenomen: het klantaandeel wan vriendem blijkit significant groter te zijn dan dat van sympathisanten en kennissen. Daanaast besteden de functionalisten procentueel ook significant meer dan kennissen.

Tabel 6.12 Procentuele bestedingen en vergelijking yan segmenten voor ex-leden

\begin{tabular}{|c|c|c|c|c|c|}
\hline Segment & Bertedingen in 0 . & Kenrissen & Functionalisten & Sympathisanten & Wienden \\
\hline Kenmissen & 17 & . & & & \\
\hline Functionalistent & 46 & $*$ & - & & \\
\hline Sympathisawnen & 31 & n.s.s. & mis. & - & \\
\hline Mrilewaten & 69 & 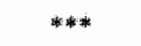 & ns. & * & - \\
\hline
\end{tabular}

Om te achterhalen of er mogelijkheden zijn de relatie te versterken, is ook hier het verschil tussen huidige en gewenste relatie nader onderzocht. Voor elk van de vier segmenten werd het huidige relatieniveau vergeleken met het gewenste relatieniveau. Daaruit bleek alleen voor het segment 'vrienden' een significant verschil te bestaan tussen het gewenste relatieniveau en hei huidige relatieniwean: de 'vrienden' onder de ex-Ieden van het Gulpener Biergilde staan open voor een sterkere relatie ${ }^{10}$.

Figuur 6.3 toont het RLM-model voor potentiële leden. De cirkelomtrek vertegenwoordigt wederom de omvang van het betreffende segment binnen de deelgroep (i.c. potentiële leden). Voor de deelgroep potentiële leden kan geen uitspraak gedaan worden over een mogelijk verband tussen RC en RFM (één van de vier cellen heeft een verwachte waarde die kleiner is dan 5).

\footnotetext{
${ }^{10}$ Het is mogelijk dat juist de 'vrienden' onder de ex-leden teleurgesteld zijn in het (huidige aanbod van het) Biergilde, maar Gulpener desalniettemin "een warm hart toedragen". Waarschijnlijk misten zij in thet Blergilde een aantal gezamenlijke activiteiten waarbuj contacten met andere leden gelegd konden worden. Ook kan het zijn dat zij als leden verwacht hadden deel te kunnen uitmaken van een consumentenpanel bij het proeven van een nieuw bier en (aldus) in een vroeg stadium op de hoogte gebracht zouden worden van nieuwe introducties (Tillemans, 1998). Aan deze verwachtingen is mogelijk onvoldoende tegemoet gekomen, hetgeen an het opzeggen wan het lidmaatschap heeft bijgedragen. Dit neemt niet weg dat zij aan dergelijke activiteiten zouden deelnemen, zodra deze zich in de toekomst alsnog zouden aandienen en aan hun oorspronkelijke verwachtingen beantwoorden. In dat opzicht sitaan zij dus nog open voor een intensievere relatie en bestaat er eern kans hen als lid te herwinnen.
} 


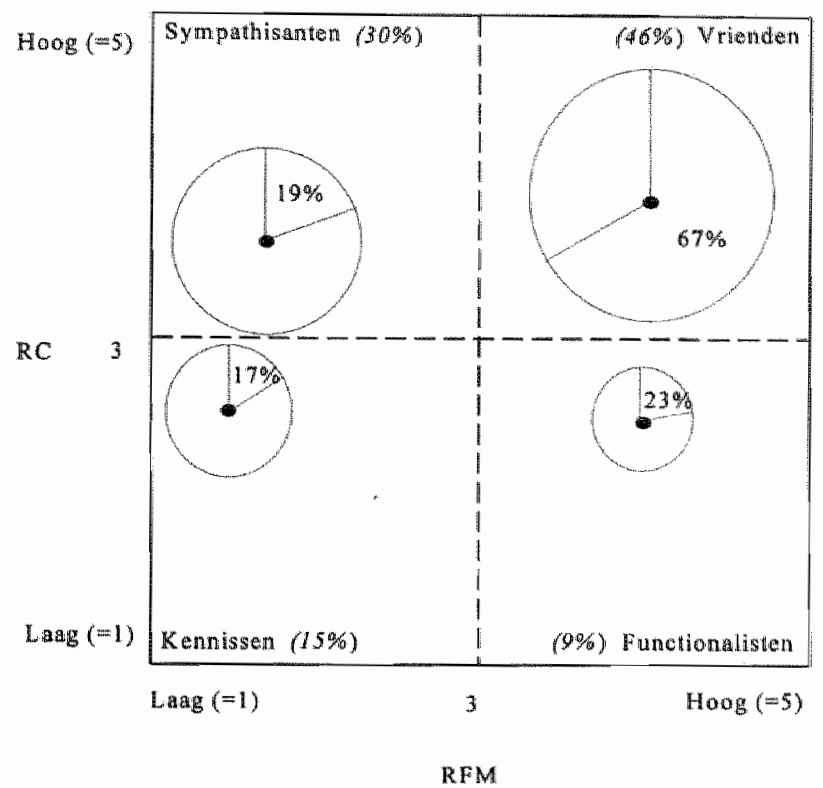

Figuur 6.3 Het RLM-model voor potentiële leden van het Gulpener Biergilde

Tabel 6.13 geeft de gemiddelde waarden voor RFM respectievelijk RC van de vier segmenten en of de segmenten eenduidig kunnen worden beschreven op basis van RC en RFM. Hetzelfde patroon als bij leden en ex-leden komt naar voren: respondenten die tot het segment sympathisanten of vrienden behoren, percipiëren een significant sterkere relatie dan respondenten die tot het segment kennissen of functionalisten behoren. Voor de economisch waardevolle segmenten vrienden en functionalisten geldt dat zij een significant hogere RFMwaarde hebben dan de segmenten sympathisanten en kennissen. RC en RFM hebben dus wederom een sterk onderscheidend vermogen.

Tabel 6.13 Warden voor RC, RFM ers vergeliking van segmenten woor potentide leden

\begin{tabular}{|c|c|c|c|c|c|c|}
\hline Segment & $R C$ & RFW & Kenmissep & Functionativten & Sympathisanten & Nianden \\
\hline Kenuissen & 2.68 & 1.53 & - & $*$ *** & b.s. & 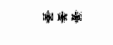 \\
\hline Functionalisten & 2.64 & 4.04 & n.s. & - & $* * *$ & n.s. \\
\hline Sympathisanten & 3.57 & 1.74 & $* * *$ & $* *$ & - & $*$ \\
\hline Vrienden & 3.76 & 4.09 & $* * *$ & *** & ra.s. & . \\
\hline
\end{tabular}

Beneden de dingowal stan de verschillen voor RC, boven de diagonoul stam die voor RFM weergegeven M.s.: whet sigwificant

Tabel 6.14 geeft aan hoeveel procent van de bieraankopen gemiddeld genomen door de respondenten van de vier segmenten aan Gulpener bier besteed wordt en of er sprake is van 
significante verschillen tussen de segmenten voor dit "klantaandeel". Het klantaandeel van vrienden blikt significant groter te zijn dan elk van de drie overige segmenten (kennissen, functionalisten en sympathisanten).

Tabel 6.14. Procentuele bestedingen en vergelijking van segmenten voor potentiële leden

\begin{tabular}{|c|c|c|c|c|c|}
\hline Segment & Bestedingen in $\%$ & Kenmissen: & Functionalisten & Sympathisanten & Nienden \\
\hline Kennusen & 17 & - & & & \\
\hline Functionalisten & 23 & 10.5: & $=$ & & \\
\hline Spmpathisanien & 19 & a.s. & n.s. & - & \\
\hline Wrienden & $6 ?$ & **** & * & $* * * *$ & - \\
\hline
\end{tabular}

Voor elk van de vier segmenten binnen de deelgroep potentiële leden werd het huidige relatieniveau vergeleken met het gewenste relatieniveau. Daaruit bleek dat voor geen van de segmenten een significant verschil kon worden aangetoond tussen huidig en gewenst relatieniveau. Potentiẻle leden, die over het algemeen een sterke relatie percipiëren (76\% behoort tot het segment sympathisanten of vrienden), vinden het huidige relatieniveau blijkbaar voldoende. Worden de segmenten onderling vergeleken, dan blijken de relatieniveaus duidelijk te verschillen: kennissen en functionalisten ondervinden én wensen een laag relatieniveau, terwijl sympathisanten en vrienden een sterke relatie beleven en ook wensen.

Aan het RLM-model is mu invulling gegeven door voor elke deelgroep een RLM-model op te stellen. De resultaten van deze analyses zijn in figuur 6.4 beknopt weergegeven. 
Hoofastuk 6: Analyse van gegevens

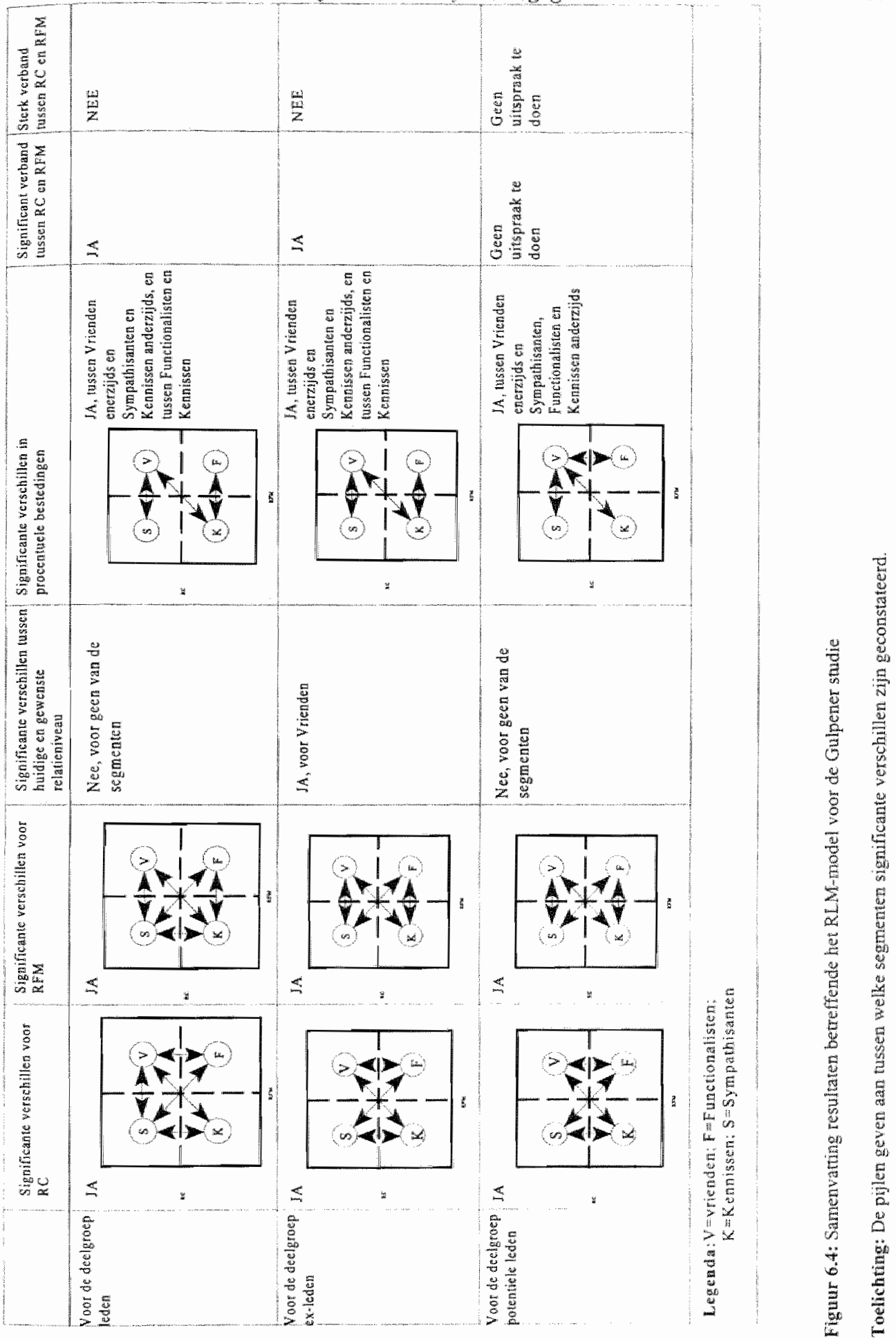


Figuur 6.4 stelt ons ook in staat de resultaten over de deelgroepen heen te evalueren en te concluderen dat:

- met behulp van RC een nader onderscheid gemaakt kan worden (binnen een in eerste instantie homogene deelgroep) tussen respondenten die een sterke en zij die een zwakke relatie ervaren;

- met behulp van RFM een nader onderscheid gemaakt kan worden (binnen een in eerste instantie homogene deelgroep) tussen respondenten die als zeer waardevol en zij die als minder waardevol voor de organisatic aangemerkt kumnen worden;

- er weliswaar cen positief, maar zwak werband tussen RC en RFM bestaat, hetgeen er op duidt dat RC en RFM als verschillende dimensies binnen een relatie gezien moeten worden; en,

- het, gelet op de procentuelle bestedingen ('customer share'), zinvol is afnemers op beide dimensies aan te sturen en tot 'vrienden' te promoveren.

Op basis van de Gulpener studie wordt geconcludeerd dat hypothese 2, 'het koopgedrag (de loyaliteit) van een klant is eenduidig positief gerelateerd aan de sterkte van de relatie met de aanbieder zoals door de klant gepercipieend", werworpen dient te worden.

Een deell van de klanten van Gulpener (3.c. functionalisten) is immers loyaal (in termen van koopgedrag), maar percipiëert geen sterke relatie met Gulpener. Het gaat dan om 9\% van de leden, $9 \%$ van de potentièle leden en $11 \%$ van de ex-leden. Daarnaast geldt dat een nog groter deel van de klanten van Gulpener (i.c. sympathisanten) weliswaar een sterke relatie percipièt, maar dit niet in het eigen koopgedrag tot uitdrakking brengt (het betreft dan $23 \%$ van de leden; $27 \%$ van de ex-leden; en $30 \%$ van de potentiele leden). Gedrag is dan voor 32 tot $39 \%$ van de consumenten geen goede indicator voor relatiesterkte en kan niet als synoniem van relatiesterkte gezien worden. Dit wordt ondersteund door maatstaven voor de mate van associatie (contingentiecoefficiënt en Phi), die op een zwak verband tussen RFM en RC duiden. Met andere woorden: ondanks dat in theorie en praktijk een goede klant en een klant die een sterke relatie percipieert met elkaar worden geildentificeerd, zijn dit verschillende concepten. Zij mogen dus niet an elkar gelijk gesteld worden.

\subsubsection{HET VERKLAREN VAN RELATUESTERKTE (RC)}

lin deze paragraaf zal nader onderzocht worden hoe RC, én van de twee dimensies van het RLM-model, nader verklaard kan worden uit een aantal andere belevingsvariabelen (vertrouwen, gepercipieerde overstapkosten en attractiviteit) overeenkonstig het in $\$ 4.4$ gepresenteerde model. Het is gebleken dat leden wan het Gulpener Biergilde een significant sterkere relatic percipièren dan ex-leden en potentiele leden. De vraag is dan enerzijds: kan relatiesterkte afdoende verklaard worden met behulp van het gepresenteerde model? En anderzijds: kan het verschil in relatiesterkte tussen de deelgroepen met behulp van het model verklaard worden? Daartoe zal het model, zoals gepresenteerd in hoofdstuk 4, per deelgroep getoetst worden. Dut houdt in dat 'overstapkosten', 'vertrouwen' en 'attractiviteit' als onafhankelijke variabelen zijn opgenomen en 'relatiesterkte' als afhankelijke variabele. 'Tevredenheid' is in ons model wiet alls antecedent van 'relatiesterkte' opgenomen. Op deze variabele (tevredenheid) richten wij ons eerst. 
Tevredenheid is als antecedent van vertrouwen in ons model weergegeven, ondat tevredenheid verondersteld wordt een sterk positief verband te vertonen met vertrouwen: samen worden $\mathrm{zij}$ wel als relatiekwaliteit gedefinieerd (Crosby et al., 1990; Lagace et al, 1991; Wray et al., 1994). Daarbij wordt verondersteld dat het vertrouwen groeit indien keer op keer minimaal aan de verwachtingen wordt voldaan, met andere woorden: indien de afnemer tevreden is (Peelen, 1989; Wilson, 1990; Ganesan, 1994). In regressie-analyses, waarin naast de variabelen vertrouwen, attractiviteit en overstapkosten ook de variabele tevredenheid als directe bepalende variabele getest werd, leverde deze laatste variabele (tevredenheid) geen significante bijdrage aan de verklaring van relatiesterkte $(p>05)$. Wel vertoont tevredenheid een significant positief verband met vertrouwen: de Pearson correlatie-coëfficiënt bedraagt .45. Dit verband geldt ook binnen elk van de deelgroepen. Voor de afzonderlijke deelgroepen bedraagt deze coëfficiënt 45 voor leden, .43 voor ex-leden en .53 voor potentiële leden. Het opnemen van tevredenheid als variabele die relatiesterkte verklaart, naast de variabelen vertrouwen, overstapkosten en attractiviteit, zou dus tevens tot multicollineariteit kumnen leiden". Tevredenheid vertoont dus een positief verband met vertrouwen en wordt, tezamen met de door ons veronderstelde causaliteit, als antecedent van vertrouwen beschouwd.

Hypothese 3.4, "er bestaat een positief verband tussen tevredenheid over de relatie met een aanbieder en het vertrouwen in die aanbieder', wordt niet verworpen.

Tabel 6.15 geeft een overzicht van de Pearson correlatiecoëfficiënten voor de bepalende variabelen in ons model: 'vertrouwen', 'overstapkosten' en 'attractiviteit'. Uit tabel 6.15 blijkt dat de (positieve) correlaties tussen de bepalende variabelen niet duiden op de mogelijke aanwezigheid van multicollineariteit. Ook voor de afzonderlijke deelgroepen komen de Pearson correlatiecoëfficiënten niet boven de .40 .

Tabel 6.15 Pearson correlatiecoe̊fficiënten voor attracitiviteit, overstapkosten en vertronwen

\begin{tabular}{lccc}
\hline & vertowwen & overstapkosien & atractiviteir \\
\hline vertrouwern & - & 470 & 505 \\
oversiapkositen & $.40^{* *}$ & - & 467 \\
attractiviteit & $.33^{*}$ & $.31 * *$ & - \\
\hline
\end{tabular}

Beneden de diagonaal staan de correlaties vermeld, bowen de diagonaal het antal cases

"Om betrouwbare conclusies te kunnen trekken met behulp van de regressiecoëfficiënten wordt alss vuistregel veelal gehanteerd dat geen van de correlatiecoëfficiënten tussen elk paar van onafhankelijke (verklarende) variabelen de waarde $50 \mathrm{mag}$ overschrijden (Kooiker en Van den Heuvel, 1992; De Pelsmacker en Van Kenhove, 1994; Zwart, 1994). Indien er een "hoge" correlatie tussen de verklarende variabelen bestaat, worden de regressiecoëfficiènten onzeker (onbetrouwbaar), waardoor over de bijdrage van de afzonderlijke variabelen geen duidelijke uitspraak is te doen. 
Op basis van de variabelen vertrouwen, attractiviteit en overstapkosten worden vervolgens drie additieve functies voor relatiesterkte opgesteld ${ }^{12}$, voor elk wan de deelgroepen éen.

\begin{tabular}{|c|c|c|c|c|}
\hline $\begin{array}{l}\mathrm{RC}_{\text {pexen }} \\
(\mathrm{t}-\text { watarde: })\end{array}$ & $\begin{array}{l}=.83 \\
\left(3.10^{*}\right)\end{array}$ & $\begin{array}{l}* .35 \text { Vertrouwen } \\
\left(5.88^{*}\right)\end{array}$ & $\begin{array}{l}+24 \text { Atractiviteit } \\
(3.87 * *)\end{array}$ & $\begin{array}{l}+.15 \text { Overstapkosten } \\
(3.54 *)\end{array}$ \\
\hline beta-cosffieient: & & 39 & .25 & .24 \\
\hline $\begin{array}{l}\mathrm{R}^{2}=.44 \\
\mathrm{R}^{2}{ }_{\text {adjusted }}=.43\end{array}$ & \multicolumn{4}{|c|}{ Futwarde $=39.77(p<0.001)$} \\
\hline $\begin{array}{l}\mathrm{RC}_{\text {exr-leden }} \\
\text { (t-Wadrde: }\end{array}$ & $\begin{array}{l}=.40 \\
\left(1.34^{\text {rn.s.s. }}\right)\end{array}$ & $\begin{array}{l}+.29 \text { vertrouwen } \\
(4.00 * *)\end{array}$ & $\begin{array}{l}+.32 \text { Attractiviteit } \\
(4.22 * * *)\end{array}$ & $\begin{array}{l}+.22 \text { Overstapkosten } \\
\left(3.52^{* *}\right)\end{array}$ \\
\hline 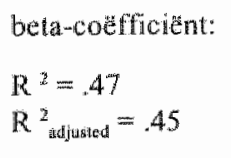 & \multicolumn{4}{|c|}{ F-watarde $=33.04(p<0.001)$} \\
\hline $\begin{array}{l}\mathrm{RC} \text { potentiate lecten } \\
\text { (t-waarde:) }\end{array}$ & $\begin{array}{l}=-.33 \\
\left(-.72^{0.5}\right)\end{array}$ & $\begin{array}{l}+.66 \text { Vertrouwen } \\
\left(5.85^{* * *}\right)\end{array}$ & $\begin{array}{l}* .22 \text { Atractiviteit } \\
\left(2.11^{*}\right)\end{array}$ & $\begin{array}{l}* .10 \text { Overstapkosten } \\
\left(1.12^{\text {n.s. }}\right)\end{array}$ \\
\hline beta-coeffficiënt: & & .60 & .20 & .11 \\
\hline $\begin{array}{l}\mathrm{R}^{2}=.54 \\
\mathrm{R}^{2}{ }_{\text {adjusted }}=.52\end{array}$ & \multicolumn{4}{|c|}{$\mathrm{F}$-waarde $=23.06(p<0.001)$} \\
\hline
\end{tabular}

De regressiecoëfficiënten zijn woor alle onafhankelijke variabelen positief. Overeenkomstig het in hoofdstuk 4 gepresenteerde model dragen "vertrouwen", "overstapkosten" en "attractiviteit" dus positief bij aan 'relatiesterkte'.

Naar aanleiding daarvan worden de hypothesen 3.1 ("Hoe groter de attractiviteit voor de consument van een relatie met cen aanbieder, hoe groter de sterkte van de relatie (mate van binding) met die aanbieder'), 3.2 ('De relatio is sterker naamate de consument hogere overstapkosten percipicent") en 3.3 ("Hoe groter het vertrouwen in de aanbieder, hoe sterker de relatie met die anbieder') niet verworpen.

De verklaarde variantie $\left(\mathrm{R}^{2}\right.$ adjusted bedraagt $43 \%$ voor leden, $52 \%$ voor potentiële leden en $45 \%$ voor ex-leden. Dit impliceert dat al veel van de variantie van RC verklaard kan worden uit de variantie in de variabelen 'vertrouwen', 'attractiviteit' en 'overstapkosten' (Bagozzi, 1994; De Pelsmacker en Van Kenhove, 1994; Zwart, 1994; Hair et al., 1995; Malhotra, 1996).

\footnotetext{
12 Er is geen reden interactie-effecten te verwachten: vanuit de beschikbare literatum wordt daartoe gecn aanleiding gegeven. De wookkeur gaat dan ook uit naar een eenwoudig lineair additief model.
} 
Wordt gekeken naar welke variabelen het meest bijdragen tot het verklaren van de variantie in de afhankelijke variabele 'relatiesterkte', dan lijkt het zinvol (met name met het oog op hypothese 4) de resultaten te ordenen overeenkomstig de volgorde waarin de geledingen in de tijd doorlopen worden ${ }^{13}$. Namelijk van potentieel lid, via lid naar ex-lid.

De relatie tussen potentiele leden en Gulpener is met name gebaseerd op 'vertrouwen'. "Vertrouwen" draagt namelijk het meest bij tot het verklaren van de variantie in RC (beta = $.60)$, op grote afstand gevolgd door "attractiviteit" (beta $=.20$ ). Ook voor leden heeft 'vertrouwen' de grootste impact op RC (beta $=.39$ ). 'Attractiviteit' (beta $=.25$ ) en 'overstapkosten" (beta $=.24)$ volgen als verklarende variabelen voor de 'relatiesterkte'. Bij exleden leveren, net als bij leden, alle drie de variabelen een bijdrage aan de verklaring voor 'relatiesterkte'. Het 'vertrouwen' van ex-leden is blijkbaar aangetast: haar relatieve belang neemt af (beta $=31$ ). 'Attractiviteit' wordt voor ex-leden de belangrijkste factor in de (voortzetting van de) relatie met Gulpener (beta $=.32$ ).

Behalve dat het relatieve belang van de variabelen verschilt tussen de deelgroepen, verschillen ook enkele constanten en regressiecoëfficiënten significant indien de verschillende functies voor de deelgroepen vergeleken worden. Zo verschilt de regressiecoëfficiënt van de variabele 'wertrouwen' voor de deelgroep potentiële leden significant van die voor zowell leden (t-waarde $=2.45 ; p<.05$ ) als ex-leden (t-waarde $=2.71 ; p<.05$ ). De constante in de functievergelijking voor potentiële leden verschilt significant van de constante in de vergelijking voor ex-leden (1waarde $=2.17 ; p<.05)$. De functies zijn dus duidelijk verschillend.

Worden de variabelen als uitgangspunt genomen, dan is het in de eerste plaats 'vertrouwen' en in de tweede plaats "attractiviteit" die een significante rol spelen bij de verklaring van (de variantie in) 'relatiesterkte'. 'Overstapkosten' spelen vervolgens een rol bij leden en ex-leden. Onze veronderstelling (dat potentiële leden, leden en ex-leden een vergelijkbare ontwikkeling doormaken of hebben doorgemaakt, voetnoot 13) in acht nemend, duiden de resultaten er op dat een relatie een dynamisch proces is. Het dynamisch patroon zoals geschetst in hypothese 4 gaat voor de Gulpener studie echter niet op.

${ }^{13}$ Aangezien het hier een cross-sectie studie betreft is het niet mogelijk de ontwikkeling van consumenten in de tijd (van potentieel lid, via lid tot ex-lid) daadwerkelijk te volgen. Hier wordt verondersteld dat potentiële leden, leden en ex-leden een vergelijkbare ontwikkeling doormaken of hebben doorgemaakt. Door vervolgens de verschillende cross-secties (van leden, potentiêle leden en ex-leden) te vergelijken bestaat de mogelijkheid een 'dynamisch patroon' te ontdekken. 
Hypothese 4 luidt:" 'Het relatieve belang van de invloedsvariabelen wijzigt in de loop van de tijd, in die zin dat attractiviteil relatief de belangrikste invloed heeft op relatiesterkte in de opbouwfase yan de relatie. Vertrouwen zal relatief de belangrijkste invloedsvariabele zijn in de fase van voortzetting en versterking van de relatie. Overstapkosten zullen relatief de belangrijkste factor van invloed op relatiesterkte vormen bij de overweging de relatie te beeindigen'. Hypothese 4 dient op basis van de resultaten werworpen te worden: hoewel het relatieve belang van de invloedsvariabelen wijzigt in de loop van de tijd, wijkt het daadwerkelijke patroon af van het in hypothese 4 geschetste patroon.

Voor afnemers van Gulpener is vertrouwen in elke fase van de relatie (potentieel lid, lid, ex-lid) (eên van) de voomaamste factor(en) van invloed op de sterkte van de relatie. Attractiviteit is eveneens van significante invloed in elk van de drie fasen en haar relatieve belang neemt toe in de loop van de relatic. Overstapkosten spelen weliswaar bij leden en ex-leden een significante rol, maar vormen niet de belangrijkste factor.

Opvallend is de bijdrage die de constante levert aan de verklaring van $\mathrm{RC}$ in de vergelijking voor leden. In tegenstelling tot de vergelijkingen voor ex-leden en potentiële leden verschilt de constante in de vergelijking voor leden significant van de waarde 0 en levert een significante bijdrage aan de verklaring van de variantie in RC. Een mogelijke verklaring hiervoor is dat leden gekenmerkt worden door een bepaald 'basis of minimumniveau' voor RC. Mogelijk is een bepaald 'basis- of minimumniveau' voor RC nodig om het lidmaatschap aan te gaan danwel te continueren, hetgeen gelet op de aard en inhoud van het Gulpener Biergilde, zoals beschreven in hoofdstuk 4 , aannemelijk is. 


\subsection{RESULTATEN GALL \& GAll STUDTE}

\subsubsection{INLEIDING}

In $\$ 6.3$ worden de resultaten van de Gall \& Gall studie weergegeven. De Gall \& Gall studie kent twee geledingen: houders van een wijnkaart (leden) en ex-houders van een wijnkaart (exleden). De resultaten van beide steekproeven worden gepresenteerd. Eerst zal wederom invulling gegeven worden aan de gedragsdimensie wan het RLM-model ( $\$ 6.3 .2)$. Vervolgens komt de belevingsdimensie aan bod. Daarbij zal nader worden ingegaan op de validiteit en betrouwbaarheid van de relationship commitment questionnaire (RCQ) $(\$ 6.3 .3)$. In $\$ 6.3 .4$ wordt invulling gegeven aan het RLM-model. In $\$ 6.3 .5$ wordt relatiesterkte gebruikt als afhankelijke variabele in het model dat gepresenteerd werd in $\$ 4.4$.

\subsubsection{LOYALITEIT}

Het onderdeel 'transactie-informatie', opgenomen in de gehanteerde vragenlijst, bevat informatie betreffende het feitelijk koopgedrag. In tabel 6.16 is informatie weergegeven betreffende het feitelijke koopgedrag van de twee deelgroepen: leden en ex-leden.

In het algemeen kan worden geconstateerd dat leden aangaande het koopgedrag significant positiever scoren dan ex-leden ${ }^{14}$. In vergelijking met ex-houders:

- hebben houders korter geleden voor het laatst wijn bij Gall \& Gall gekocht;

- kopen houders vaker wijn bij Gall \& Gall; en,

- besteden houders gemiddeld per maand meer aan wijn bij Gall \& Gall.

Uit de verkregen variabelen werd een nieuwe variabele samengesteld: RFM. In lijn met de resultaten van de afzonderlijke variabelen is de RFM-waarde ${ }^{15}$ voor leden significant hoger dan die voor ex-leden (zie tabel 6.16).

Tabel 6.16 Transactie-informatie feitelijk koopgedrag

\begin{tabular}{|c|c|c|c|c|c|}
\hline $\begin{array}{l}\text { Wraog* } \\
n \text { r. }\end{array}$ & Omschrijung & Schanal & Leden & Ex-leden & $\begin{array}{l}\text { Signt. } \\
\text { nivenat }\end{array}$ \\
\hline 7 & Voor het laatst wijn bij Gall \& Gall gekocht & 0 & $\mathrm{MO}=5 / \mathrm{ME}=4$ & $\mathrm{MO}=1 / \mathrm{ME}=2$ & 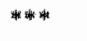 \\
\hline 8 & Koopfrequentie & 0 & $\mathrm{MO}=3 / \mathrm{ME}=3$ & $\mathrm{MO}=1 / \mathrm{ME}=2$ & *4: \\
\hline 9 & Gemiddelde besteding in guldens & U/R & 72.90 & 34.35 & * \\
\hline- & Recency, Frequency, Monetary wallue (RFM) & $\mathrm{O} / \mathrm{I}$ & 3.66 & 2.61 & **** \\
\hline
\end{tabular}

\footnotetext{
${ }^{14}$ Zie voor de betekenis wan de scores de gehanteerde vragenlijst, opgenomen in bijlage 2. Daar waar van toepassing zijn in de vragenlijst bij de items de antwoordmogelijkheden en hun corresponderende scores opgenomen.
}

is Ook hier werden, om overgewicht van de monetary vallue (de besteding per maand in guldens) te voorkomen , de bestedingen gehercodeerd tot wijf klassen, en wel als volgt:

bestedingen van 1 tot en met 10 gulden: waarde $=1$;

bestedingen van 11 tot en met 20 gulden: waarde $=2$;

bestedingen van 21 tot en met 30 gulden: warde $=3$;

bestedingen van 31 tot en met 40 gulden: waarde $=4$;

bestedingen van 41 gulden of meer: waarde $=5$. 


\subsubsection{RELATEPERCETIE}

\section{De Relationstip Comminment Questionnaire (RCQ): betronmbarheid}

De Relationship Commitment Questionnaire is opgebouwd uit 15 items. Tabel 6.17 geeft de gemiddelde scores wan elk van de vijfien items weer, zowel voor leden als voor ex-leden. De betrouwbatheid (Cronbach alpha) over alle vijhien items van de $\mathrm{RCQ}$ is .85.

Tabel 6.17 De Relationship Commitment Questionnaire (RCQ)

\begin{tabular}{|c|c|c|c|c|c|}
\hline Wadem & Omschrijuting & Schaal & Leden & $E x$-leden & Sign. nivean \\
\hline 52 & Bereid extra moeite te doen om te koper & OH & 2.69 & 233 & H. \\
\hline 53 & Aanbevelen als organisatie die kwaliteit verkoopt & $\mathrm{O} / \mathrm{I}$ & 3.46 & 2.90 & $* * * *$ \\
\hline 54 & Niver erg trouw an organisatio & $\mathrm{O} / \mathrm{L}$ & 3.47 & 2.74 & $* * *$ \\
\hline 55 & Priguerboging van $5 \%$ accepteren. & O/ & 3.06 & 2.64 & 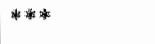 \\
\hline 56 & Warden en nomen komen sterk overeen & Of & 3.39 & 2.91 & 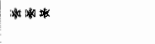 \\
\hline 57 & Trots anderen te vertellen bij organisatie te kopen & orl & 2.42 & 2.19 & wak \\
\hline 58 & Koopt net zo gemakkelijk bij andere organisatie & O/L & 2.90 & 2.46 & ******at \\
\hline 59 & Gaat gragg twrug naar organisatie & of & 3.90 & 3.55 & $* * *$ \\
\hline 60 & Weinig nodig woor owerstap op andere organisalie & $O / T$ & 3.36 & 3.09 & $* *$ \\
\hline 61 & Blij organisatie verkozen te hebben boven andere & $O / 1$ & 3.20 & 2.71 & 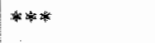 \\
\hline 62 & Net veel voordeel bij klant blijwen & o/1 & 3.35 & 2.83 & **** \\
\hline 63 & Vaak moeite met beleid van organisatic naar klant & $0 / 1$ & 4.05 & 3.79 & $* * *$ \\
\hline 64 & $U$ geeft echt om lot van organisatie & On & 2.57 & 2.17 & $* *$ \\
\hline 65 & Voor U is deze organisatie het beste alternatief & On & 324 & 2.60 & $* * *$ \\
\hline 66 & Het was verkeerde beslissing on hier te kopen & OII & 4.06 & 3.85 & $* *$ \\
\hline
\end{tabular}

Opgentherkt wordt echter dat vijf items (nl. $55,60,62,63$ en 66) weliswar een positieve, maar lage item-total correlatie vertonen ${ }^{16}$. Het weglaten van deze vijf items leidt tot een verkorte RCQ bestande uit tien items. De betrouwbarheid van deze RCQ is .86 (Cronbach alpha). Daarbij zijn alle item-lotal correlaties positief en groter dan 40 (Churchill, 1995). Dit duidt er op dat de verkorte, tien item schaal homogener is dan de uitgebreide vijftien item schaal met betrekking tot de te meten wariabele relatiesterkte (RC). In verdere analyses wordt van deze verkorte RCQ uitgegaan. Daarbij zal RC als een unidimensionele variabele worden beschouwd en behandeld: er zal een index voor RC berekend worden door de scores var de tien items op te tellen en de som te delen door tien.

${ }^{16}$ Het betreft dezelfde itens als bij de Gulpener studie, watr zes items een onacceptabele item-totaal correlatie hadden. Het item 'U woelt erg weinig loyaliteit naar Gulpener toe' (vraag 51 ) werd in de Gall $\&$ Gall studie geherformuleerd tot 'U bent niei erg trouw an Gall \& Gall' (vraag 54). Dit leidde in de Gall \& Gall studie tot een acceptabele item-total score van .62 voor dit item. 
Tabel 6.19 Prineipale Componenten Analyse op de RCQ

\begin{tabular}{|c|c|c|c|}
\hline \multirow[b]{2}{*}{ Vraagmr. } & \multirow[b]{2}{*}{ Orstschrijuing } & \multicolumn{2}{|c|}{ Factorladingen } \\
\hline & & $\begin{array}{l}\text { Factor } 1 \\
\text { (Emotioneel') }\end{array}$ & $\begin{array}{c}\text { Factor } 2 \\
\text { ('Rationel') }\end{array}$ \\
\hline 56 & Waarden en normen komen sterk overeen & .80 & \\
\hline 59 & Gaat gragh terug naar organisatie & .76 & \\
\hline 53 & Aanbevelen als organisatie die kwaliteit verkoopt & .73 & \\
\hline 61 & Blij organisatie verkozen te hebben boven andere & .69 & \\
\hline 65 & Voor $U$ is deze organisatie het beste alternatiaf & .57 & .52 \\
\hline 52 & Bereid extra moeite te doen on te kopen & & .75 \\
\hline 58 & Koopt net zo genaakkelijk bij andere organisatie & & .70 \\
\hline 57 & Trots anderen te wertellen bij organisatie te kopen & & .64 \\
\hline 64 & U geeft echt om lot van organisatie & & .55 \\
\hline 54 & Niet erg trouw aan organisatic & .46 & .48 \\
\hline \multicolumn{2}{|c|}{ variantie $(\%)$} & 44.9 & 10.3 \\
\hline \multicolumn{2}{|c|}{ Eigenwaarde } & 4.49 & 1.03 \\
\hline
\end{tabular}

In $\$ 2.3 .1$ is cen relatie gedefinieerd als een door economische en niet-economische doelstellingen geleid interactieproces tussen een aanbieder en een consument in verband met de aanschaf en het ge-/verbruik van huishoudelijke goederen en diensten. Gesteld werd dat vanuit de consument gezien de redenen voor een relatie veelal in twee categorieën kunnen worden ondergebracht: emotionele (niet-economische) en rationele (economische) gronden (zie ook $\$ 4.4,2$ en $\$ 5.4 .3)$.

De twee-factoren oplossing lijkt er op te duiden dat in de relatie tussen afnemers en Gall \& Gall zowel emotionele (niet-economische) gronden als rationele (economische) gronden een expliciete rol spelen.

Factor 1 duidt op een band tussen afnemer en ambieder die zijn fundament heeft in emotionele beweegredenen. Indien waarden en normen wan Gall \&. Gall goed aansluiten bij de eigen waarden en nomen, kan de afnemer zich sociaal identificeren met de aabieder. Dat een afnether graag terug gaat naar Gall \& Gall is mogelijk toe te schrijven aan het feit dat hij zich psychisch comfortabel/op zijn gemak voelt bij Gall \& Gall en komt mogelijk eveneens voort uit de persoonlijke behoefte om cognitieve consistentie te handhaven. Ook het aanbevelen van Gall \& Gall bij vrienden gebeurt met name indien je je als afnemer gevoelsmatig positief kunt associëren en identificeren met Gall \& Gall.

Daarnast spelen in de relatie met Gall \& Gall ook rationele overwegingen mogelijk een grote rol, gelet op factor 2. Of een afnemer bereid is extra moeite te doen om bij Gall \& Gall te kopen en of hij bij een vergelijkbaar assortiment net zo gemakkelijk bij een ander aankooppunt koopt. wordt mogelijk in hoofdzaak bepaald door een rationele afweging van woor- en nadelen, kosten en opbrengsten, Dit soort rationele overwegingen spelen bij Gulpener waarschijnlijk een minder prominente rol, omdat de afnemer Gulpener-produkten niet bij Gulpener zelf, maar bij 
een in het algemeen onafhankelijke internediair koopt. De rationele beweegredenen die in de relatie met Gall \& Gall expliciet naar voren komen, zullen bij Gulpener mogelijk eveneens in de relatie met het daadwerkelijke aankooppunt voor Gulpener-produkten spelen. In de relatie met de Gulpener organisatie zelf domineren dan de emotionela beweegredenen. Dit komt deels al tot uitdrukking in de resultaten met betrekking tot het verklaren van relatiesterkte in de Gulpener studie. Daar blijkt RC primair verklaard te kunnen worden uat vertrouwer in Gulpener als organisatie. Onze verwachting is dan ook dat in de relatie met Gall \& Gall vertrouwen een relatief minder dominante rol zal spelen.

De factoroplossingen geven op die manier nader inzicht in de ard van de relatie, waarbij een onderscheid gemaakt kan worden tussen rationele en emotionele beweegredenen (o.a. Peelen, 1989b), of naw daarmee samenhangend: de formele en informele aspecten van de imteractie (Poiesz en Van $\mathbb{R}$ aaij, 1993; zie ook \$2.3.1, voetnoot 1). Op (onderzoek naar) de aard van de rellatie komen we in hoofdstuk 7 nader teng. Daarbij wordt nader ingegan op affectief en calculatief commitment.

\section{De Relationship Commitment Questionnaime (RCQ): validiteit}

Voor wat betreft validiteit wordt hier ingegaan op face-validity en discriminant-validity.

Wat voor de Gulpener studie geldt ten aanzien van face-validity, gaat ook op voor de Gall $\&$ Gall studie. In de hoofdstukken 4 en 5 (met name $\$ 5.5$ ) is daarover reeds uitvoerig gerapporteerd. Gesteld kan worden dat er sprake is van face-validity.

Voor wat betreft discriminant-validity wordt gesteld dat lage correlatie-coefficiènten tussen overstapkostem, attractiviteit, tevredenheid en vertrouwen enerzijds en RC anderzijds er op duiden dat er sprake is wan verschillende constructen.

Aan (de betrouwbaarheid van) de constructen overstapkosten, attractiviteit, tevredenheid en vertrouwen zal eerst aandacht besteed worden alvorens verder ingegaan kan worden op de discriminant validiteit.

Het onderdeel 'beleving van de relatie' in onze vragenlijst bevat informatie over de houding van de respondenten ten aanzien van: overstapkosten, vertrouwen, tevredenheid en attractiviteit. De betrouwbaarheid (Cronbach alpha) van de gepercipieerde overstapkosten is 67. Voor vertrouwen bedraagt deze .60 . Voor tevredenheid en attractiviteit bedraagt de Cronbach alpha .80 respectievellik .52. Met uitzonderng van de warde voor tevredenheid is met name de alpha coefficiënt voor attractiviteit laag te noemen (kleiner dan .60). Bovendien blijkt voor de variabelen gepercipieende overstapkosten, vertrouwen en attractiviteit een aantal item-totaalcorrelaties lager te zijn dan 40 . Voor de variabele overstapkosten betreft het de items 32 en 33 . Bij de variabele vertrouwen is het item 39 dat voor en lage alpha coefficient verantwoordelijk is. $B i j$ attractiviteit zijn het de items 46,47 en 49 die een lage item-totaal correlatie vertonen. Het gevolg is dat altractiviteit door slechts eén item (48) zal worden vertegenwoordigd. Het verwijderen van de betreffende items $(32,33,39,46,47$ en 49$)$ leidt tot de Cronbach alpha waarden die weergegeven zijn in tabel 6.20. De na item-analyse resterende items vertonen alle item-totall correlaties die groter zijn dan 40 
Tabel 6.20 Overzich Cronbach alpha warden voor de variabellen: gepercipieerde overstapkosten, vertrowswen en tevredentheid

\begin{tabular}{lccc}
\hline & Aantal items & Cronbach alpha & $n$ \\
\hline overciapkostan & 4 & .76 & 432 \\
wertrouwen & 2 & .65 & 450 \\
tevredenheid & 2 & .80 & 446 \\
\hline
\end{tabular}

n: antal respondenter in de and lyge

Van de constructen 'overstapkosten', 'vertrouwen' en 'tevredenheid', die uit meerdere items bestaan (na coëfficiènt alpha aralyse en item-analyse), zijn indices berekend door het ongewogen gemiddelde te nemen van de warden van de afzonderlijke items. Deze indices staan vermeld in tabel 6.21 .

Ten aanzien van de samengestelde variabelen kan vastgesteld worden dat zowel leden als exleden: - nauwelliks overstapkosten percipiëren;

- in hoge mate vertrouwen hebben in Gall \& Gall; en,

- $\quad$ in dezelfde mate tevreden zijn met Gall \& Gall.

Tabel 6.21 Balcving wan do rellate: samengestelde variabelen

\begin{tabular}{|c|c|c|c|c|}
\hline Farabele & Sichan & Leden & Ex-Reden & Sign niwear \\
\hline Overstapkosten & Oll & 2.13 & 2.02 & $\infty$ \\
\hline Verthouwen & On & 4.07 & 3.98 & m \\
\hline Tevredenheid & $\mathrm{OH}$ & 4.06 & 3.96 & $=$ \\
\hline
\end{tabular}

Met behulp van deze constructen kan nu een indicatie verkregen worden van de discriminant validiteit.

In tabel 6.22 zijn de Pearson correlatie-coefficiënten weergegeven tussen RC enerzijds en overstapkosten, attractiviteit, tevredenheid en vertrouwen anderzijds. Alle correlatiecoeflicienten liggen sigmificant beneden de waarde $\mathbb{1}$. Dit impliceert een zekere mate van. discriminant waliditeit (Kumar et a1., 1995a; 1995b).

Tabel 6.22 Pearson correlaties ( $)$ tussen RC enerzijds en overstapkosten, attractiviteit, tevedentheid en vertrouwen anderzijis

\begin{tabular}{|c|c|c|}
\hline & $p$ & $m$ \\
\hline owerstapkosten & $.28 *$ & 282 \\
\hline afractiviteit & .600 & 291 \\
\hline torredenheid & 43 & 285 \\
\hline vertrolwen & $.32 *$ & 289 \\
\hline
\end{tabular}

***: $p<.001 ;$ : a antal responderten in de analyse

Hoewel de bevindingen ten anzien van discriminant validiteit tot dusverre acceptabel zijn, is de mate van discriminant validiteit ook getoetst via confimatorische factoranalyse (CFA) op de 
geselecteerde items van de nulti-item constructen 'RC", "gepercipteerde overstapkosten' en 'vertrouwen' (Hair et al., 1995). De CFA werd uigevoerd met LISREL 7.20 en leverde een Chi-kwadraat op van 241.81 (101 vrijheidsgraden, $p<.001 ; n=278$ ) en een 'adjusted' Chikwadraat (Chi-kwadrat/vrijheidsgraden) van 2.39. De Goodness of Fit index (GFD) bedraggt 90, de Adjusted GFI (A,GFI) is .86 en de Root Mean Square Residual (RMSR) bedraagt 06. Alle factorladingen zijn zeer significant (minimum t-waarde was 7.34) en overtroften het 40 miveau dat algemeen als betekenisvol word beschouwd in factor-analyse (Ford et al, 1986). Deze resultaten duiden er op dat de discrimmant validiteit redelijk is: de constructen zijn redelijk verschillend van elkaar.

Op basis van het voorgaande wordt de mate van interne consistentie betrouwbarheid en inhoudvaliditeit van de RCQ voldoende geacht, terwijl de mate van discriminant validiteit redelijk is. Daamee kan hypothese 1 voor de Gall \& Gall studie niel verworpen worden: de relationship commitment questionnaire (RCQ) is een betrouwbare en valide meetschat voor het vaststellen van de sterkte van relaties tussen een aambieder en zijn cindafnemers, $i$. consumenten.

\subsubsection{HET RLM-MODEL VOOR DE GALL \& GALL STUDIE}

In de vorige paragraaf is vastgesteld dat de $\mathrm{RCQ}$ een betrouwbare en valide meetschaal is voor het vaststellen van de relatiesterkte ( $R C$ ) tussen een aanbieder en zijn eindafnemers. In deze paragraaf wordt $\mathrm{RC}$ als segmentatievariabele toegepast in situaties waarin niet op voorhand segmenten te onderscheiden zijn die verschillen in relatiesterkte. Daartoe zal per deelgroep een RLM-model opgesteld worden en de vier segmenten daarbinnen nader geanalyseerd worden. Doel daarvan is te onderzoeken of de segmenten bimen elke deelgroep significante verschillen vertonen voor beide dimensies en dus op basis van deze dimensies eenduidig beschreven kumnen worden. Indien dat het geval is, rechtwaardigt dat een specifteke benadering van deze segmenten en wordt nader inzicht verkregen in de samenstelling van de betreffende deelgroep. Om op die mogelijke verschillen in te spelen en verschuivingen aan te brengen binnen de RLM-matrix wordt gekeken naar het verschil in huidig en gewenst relationveau (op basis van de vragen 35 respectievelijk 37 van de vragenlijst) en naar de procentuele bestedingen van de klant aan wijn bij Gall \& Gall (vraag 14). Het verschil in huidig en gewenst relatieniveau bied namelijk nader inzicht in de mogelijktheid en wenselijkheid de relatie te intensiveren en dus RC te beinvloeden. Het klantaandeel geeft infomatic over hel nog brakliggende bestedingspotentieel dat via het aansturen van het koopgedrag. (RFM) benut kan worden.

Tabel 6.23 geeft de omvang van de vier segmenten per deelgroep weer. Gelet op de diversiteit in de samenstelling van de deelgroepen lijkt het zimvol om het gegeven of iemand als kennis, functionalist, sympathisant of als vriend aangemerkt kan worden, als criterium te nemen voor een specifieke klantbenadering, naast de 'status' van de respondent (kaarthouder of voornalig kaarthouder).

Aansluitend zal elk van de deelgroepen nader in beschouwing genomen worden, to beginen met de leden, gevolgd door de ex-leden van het Gall \& Gall wijnkaarthoudersprogramma. In 
totaal zullen 219 respondenten in deze analyses worden meegenomen ${ }^{17}$. In bijlage 6 is een overzicht opgenomen warin de respondenten die in de analyses zijn meegenomen, op meerdere verschillende aspecten vergeleken worden met respondenten die niet in de analyses zijn megenomen. In slechts 3 van de 26 onderzochte vergelijkingen werden significante $(p<.05)$ verschillen aangetroffen. Dit is een indicatie dat er natwelijks verschillen tussen de wee response-gropen bestaan.

Tabct 6.23 Verdeling van leden en ex-leden wan het Gall \& Gall wijnkaarthoudersprogramma over de vier collen wan het RLM-model

\begin{tabular}{|c|c|c|c|c|c|}
\hline & Kenfinsen & Functionalisten & Sympathisanden & Prienden & Totaal \\
\hline Ledien & $22(16 \%)$ & $35(26 \%)$ & $15(11 \%)$ & $62(47 \%)$ & $134(100 \%)$ \\
\hline Extleden & $36(42 \%)$ & $22(26 \%)$ & $13(15 \%)$ & $14(17 \%)$ & $85(100 \%)$ \\
\hline Totanal & 58 & 57 & 28 & 76 & $219(100 \%)$ \\
\hline
\end{tabular}

Figuur 6.5 toont het RLM-model voor leden. De cirkelomtrek vertegenwoordigt de omvang van het betreffende segment binnen deze deelgroep. Er is sprake van een positief verband tussen RC en RFM (Chi-kwadraat $=5.070 ; p=.024)$. Het verband is echter als $z$ wak aan te merken, daar zowel Phi als de contingentiecoëfficiẽnt $\mathrm{C} .19$ bedraagt.

${ }^{17}$ Deze respondenten hebben alle 13 items beantwoord. RC is immers opgebouwd uit 10 en RFM uit 3 items. Het aantal respondenten ligt dan ook lager dan het aantal respondenten dat alleen op de 3 items van RFM, respectievelijk op de 10 items van RC geantwoord heeft. De aanwezigheid wan item non. response (Churchill, 1995) speelt hier dus een grote rol bij het aantal nespondenten dat in de analyses wordt meegenomen. Besloten is on de 'missing values' miet te vervangen door de gemiddelde waarde voor het betreffende item op basis van zij die wel respondeerden. De nadere segmentatie die wij willen aanbrengen naar kennissen, sympathisanten, vrienden en functionalisten dient namelijk plaats te vinden op basis van de feitelike waarden voor RFM en RC voor de betreffende respondent en niet op basis van een gemiddelde waarde voor de hele deelgroep (lleden respectievelijk ex-leden). 


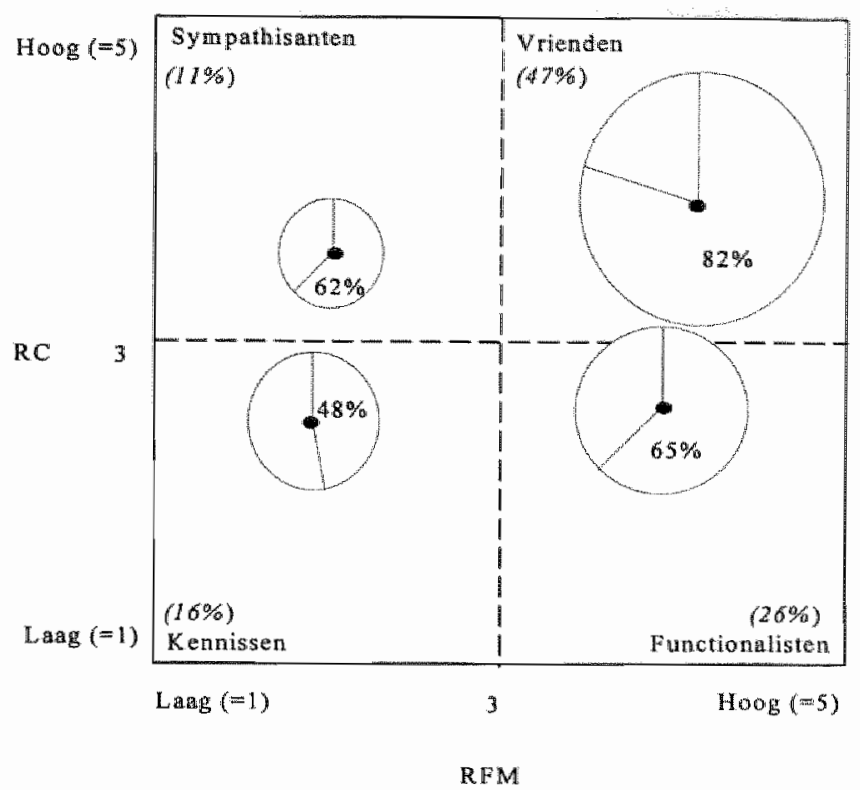

Figuur 6.5 Het RLM-model voor houders van de Gall \& Gall wijnkaart

Tabel 6.24 geeft de gemiddelde waarden voor RFM en RC van de vier segmenten. Tevens staan in deze tabel de significante verschillen aangegeven tussen de segmenten voor deze variabelen. Het blijkt dat de respondenten die tot éen van de segmenten sympathisanten en vrienden behoren een significant sterkere relatie percipiëren dan respondenten die tot én van de segmenten kennissen en functionalisten behoren. Voor de economisch waardevolle segmenten vrienden en functionalisten geldt dat zij een sigmificant hogere RFM-waarde hebben dan de segmenten sympathisanten en kennissen. RC en RFM hebben dus een sterk onderscheidend vermogen.

Tabel 6.24. Waarden voor RC, RFM en vergelijking van segmenten woor leden

\begin{tabular}{|c|c|c|c|c|c|c|}
\hline Segrient & $R C$ & $R F M$ & Kennissen & Fumctonalisten & Sympathisanten & Wiciden \\
\hline Kentwissen & 2.47 & 2.03 & - & **** & n.s. & 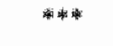 \\
\hline Functionalisten & 2.61 & 4.21 & n.s. & - & $* * * *$ & n.s. \\
\hline Sympathis anten & 3.49 & 2.15 & *** * & $* * *$ & - & $* * *$ \\
\hline Vriendert & 3.66 & 4.35 & $* * *$ & * * * & n.s. & - \\
\hline
\end{tabular}

Beneden de diagonat staan de verschillen voor $R C$, boven de diagonaal staan die voor RFM weergegevent M.s.s: viet sigmificant

Tabel 6.25 geeft aan hoeveel procent van de wijmaankopen gemiddeld genomen door de respondenten van de vier segmenten bij Gall \& Gall besteed wordt en of er sprake is van 
significante verschillen tussen de segmenter voor dit "klantaandeel". Het klantaandeel van vrienden blikt significant groter te zijn dan elk van de drie overige segmenten (kennissen; functionalisten en sympathisanten).

Tabel 6.25 Procentuele bestedingen wergelijking van segmenten voor leden

\begin{tabular}{lccccc} 
Segnient & Bestedingen in & Kennissen & Functionalisten & Sympathisanten & Vriendem \\
\hline Kennissen & 48 & - & & \\
Functionalistent & 65 & n.s. & - & - \\
Sympathisanten & 62 & n.s. & n.s. & $*$
\end{tabular}

\section{H.s.: niet sigrificant}

Voor wat betreft de mogelijkheden de relatie te intensiveren is wederom gekeken naar het verschil tussen huidige en gewenste relatie. Alleen voor vrienden blijkt er een significant werschil te bestaan: het gewenste niveau is significant hoger dan het huidige niveau.

Figuur 6.6 toont het RLM-model woor ex-leden. De cirkelomtrek vertegenwoordigt de omvang van het betreffende segment binnen deze deelgroep. Er is géen sprake van een verband tussen RC en RFM (Chi-kwadrat $=948 ; p=3$ ), hetgeen ook blijkt uit de contingentiecoëfficiènt $\mathrm{C}$ alsmede Phi, die beide een waarde van .11 aannemen, hetgeen er op duidt dat er niet of nauwelijks van een verband gesproken kan worden.

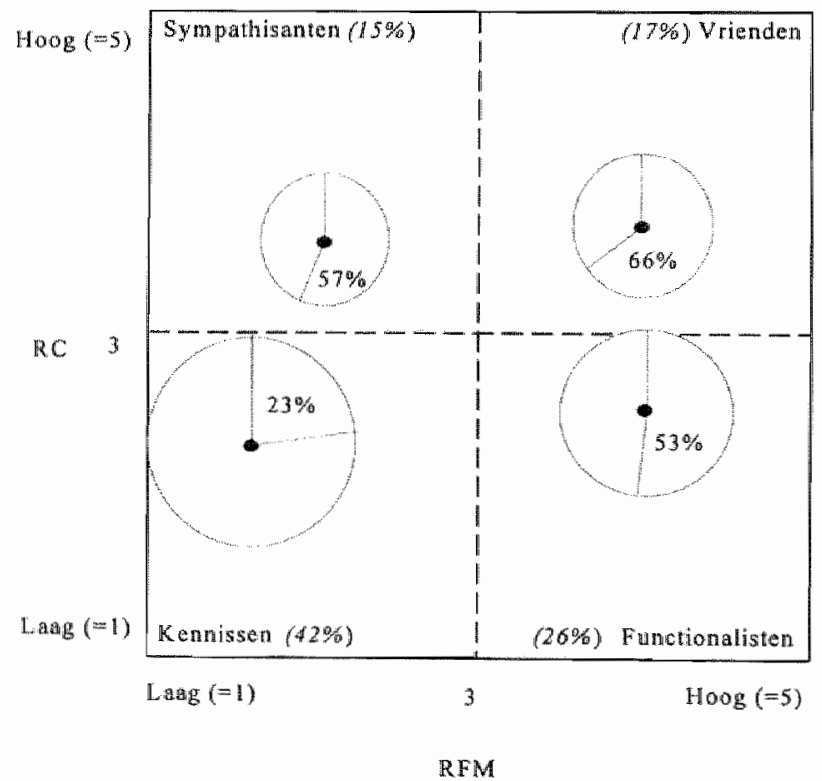

Figuur 6.6 Het RLM-model voor ex-houders van de Gall \& Gall wijnkaart 
Tabel 6.26 geeft de gemiddelde waarden voor RC respectievelijk RFM van de vier segmenten, alsmede of de segmenten significant van elkaar verschillen en dus eenduidig kumnen worden beschreven op basis van RC en RFM. Ook hier blijkt dat de respondenten die tot de segmenten sympathisanten en vrienden behoren een significant sterkere relatie percipièren dan respondenten die tot de segmenten kennissen en functionalisten behoren. Voor de economisch waardevolle segmenten vrienden en functionalisten geldt dat zij een significant hogere RFMwarde hebben dan de segmenten sympahisanten en kennissen. RC en RFM hebben dus ook in geval van ex-leden een sterk onderscheidend vermogen.

Tabel 6.26 Waarden voor RC, RFM en vergelijking van segmenten woor ex-leden

\begin{tabular}{|c|c|c|c|c|c|c|}
\hline Segment & $R C$ & $R F M$ & Kemissen & Functionalssters & Sympathisanten & Wrienden \\
\hline Kennissest & 2.40 & 1.54 & - & $*$ *ar & n.s. & * * * \\
\hline Funcrionalisten & 2.62 & 3.94 & n.s. & - & $* *$ * * & n.s. \\
\hline Sympahisanten & 3.53 & 2.12 & $* * *$ & ****2 & - & 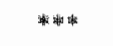 \\
\hline Fienden & 3.58 & 3.96 & $* * *$ & $* * *$ & $\mathrm{~ns} . \mathrm{s}$ & - \\
\hline
\end{tabular}

Beneden de diagonaal statan de verschillen voor $R C$, boven de diagonaal staatn die voor $R$ Far weergegeven n.S.: niet significant

In tabel 6.27 staat weergegeven welke significante verschillen zijn aangetroffen indien de segmenten paarsgewijs met elkaar worden vergeleken voor de procentuele bestedingen aan wijn bij Gall \& Gall. Kennissen onderscheiden zich in negatieve zin van de overige drie segmenten doordat kennissen een significant geringer deel van hun bestedingen aan wijn bij Gall \& Gall besteden.

Tabel 6.27 Procentuele bestedingen en vergelijking van segmenten voor ex-leden

\begin{tabular}{|c|c|c|c|c|c|}
\hline Segment & Bestedingen in $\%$ & Kennissen & Functiomalisten & Sympathisamern & Fienden \\
\hline henmissen & 23 & - & & & \\
\hline Furnchonalisten & 53 & 壮 & 。 & & \\
\hline Sympandisanten & 57 & * & 1..3. & - & \\
\hline Vrierden & 66 & *** & nus. & Di.S. & $\ldots$ \\
\hline
\end{tabular}

\section{S: niet significant}

Voor wat betreft de mogelijkheden de relatie te intensiveren is wederom gekeken nat het verschil tussen huidige en gewenste relatie. Daaruit blijkt dat onder de ex-leden alleen de kennissen open staan voor een intensievere relatie.

Het RLM-model is nu invulling gegeven door voor elke deelgroep een RLM-model op to stellen. Figurur 6.7 vat de resultaten voor deze analyses samen. 


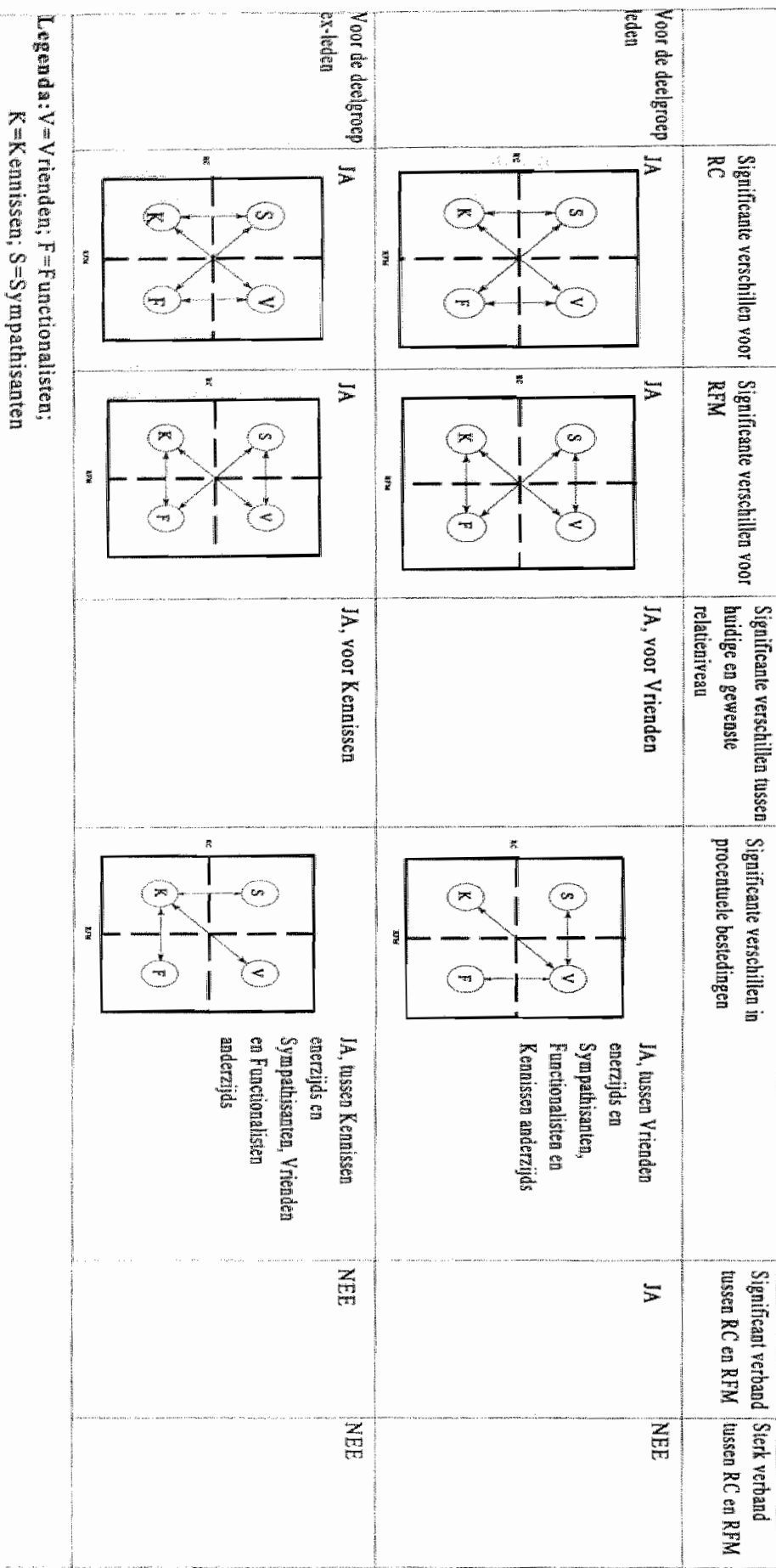


Geconcludeerd kan worden dat:

- relatiesterkte $(\mathrm{RC})$ gebruikt kan worden om een nader onderscheid aan te brengen tussen respondenten die een sterke relatie percipierren en respondenten die een zwakke relatie percipiëren;

- RFM waardevolle van minder waandevolle respondenten onderscheidt:

- RFM niet als indicator voor RC gezien moet worden, maar dat RC en RFM verschillende dimensies binnen een relatie vertegenwoordigen.

Op basis van de Gall \& Gall studie wordi geconcludeend dat hypothese 2, "het koopgedrag (de loyaliteit) van een klant is eenduidig positief gerelateerd aan de sterkte van de relatie met de aanbieder zoals door de klant gepercipieerd", verworpen dient te worden.

Een deel van de klanten van Gall \& Gall (i.c. functionalisten) is immers loyaal (in termen van koopgedrag), maar percipiëert geen sterke relatie met Gall \& Gall. Het gaat dan on $26 \%$ van de leden en eveneens $26 \%$ van de ex-leden. Omgekeerd geldt dat cen deel van de klanten van Gall \& Gall (i.c. sympathisanten) weliswaar een sterke relatie percipièert, maar dit niet in het eigen koopgedrag tot uitdrukking brengt (het betreft dan $11 \%$ van de leden en $15 \%$ van de ex-leden). Gedrag is dan voor 37 tot $41 \%$ wan de consumenten geen goede indicator voor relatiesterkte en kan niet als synonjem van relatiesterkte gezien worden. Dit wordt door de waarden voor de contingentiecoefficiënt alsook Phi bevestigd. Met andere woorden: ondanks dat in theorie en praktijk een goede klant en een klant die een sterke relatie percipieert met elkaar worden geïdentificeerd, zijn dit verschillende concepten. Zij mogen dus niet aan elkaar gelijk gesteld worden.

\subsubsection{HET VERKLAREN VAN RELATIESTERKTE (RC)}

Het is gebleken dat wijnkaarthouders een significant sterkere relatie percipiëren dan exwijnkaarthouders. In deze paragraaf zal onderzocht worden of relatiesterkte (RC), eên van de twee dimensies van het RLM-model, verklaard kan worden met behulp van het in hoofdstuk 4 gepresenteerde model. In dat model vormen 'overstapkosten', "vertrouwen' en 'attractiviteit' de drie onafhankelijke variabelen die direct van invloed zijn op relatiesterkte. Tevens wordt in deze paragraaf een anwoord gezocht op de vaag of het verschil in relatiesterkte wssen de deelgroepen met behulp van het model nader verklaard kan worden. Daartoe wordt voor beide deelgroepen een functie opgesteld. Eerst richten we onze aandacht echter op de variabele 'tevredenheid'. 'Tevredenheid' is in ons model opgenomen als een variabele die indirect, via "vertrouwen", invloed uitoefent op 'relatiesterkte". "Tevredenheid' wordt verondersteid cen sterk positief verband te vertonen met vertrouwen, waarbij het vertrouwen groeit indicn de afnemer keer op keer tevreden is omdat de geleverde prestaties telkens aan zijn verwachtingen voldoen. Er blijkt inderdaad een significant positief verband te bestaan tussen 'tevredenheid' en "vertrouwen": de Pearson correlatiecoefficient blijkt 48 te bedragen. Dit verband geldt ook binnen elk van beide deelgroepen. Yoor de afzonderlijke deelgroepen bedraagt deze coëfficięnt .45 voor leden en 51 voor ex-leden. Het opnemen van 'tevredenheid' als directe verklarende variabele van 'relatiesterkte', maast 'vertrouwen', zou dus tevens tot multicollineariteit kunnen leiden daar de warde van de correlatiecoefficiënt groter dan .50 is (Kooiker en Van den Heuvel, 1992; De Pelsmacker en Van Kenhove, 1994; Zwari, 1994). 
Tevredenheid en vertrouwen hangen duidelik met elkaar samen. Dit, tezamen met de door ons veronderstelde causaliteit, is een indicatie dat hypothese 3.4 ( $\mathrm{Er}$ bestaat een positief verband tussen tewredenheid over de relatie met een aanbieder en het vertrouwen in die aanbieder ) niet wordl verworpen.

Tabel 6.28 geeft en overzicht van de Pearson correlatiecoefficiènten voor de bepalende variabelen in ons model: "vertrouwen", 'overstapkosten" en "attractiviteit". De correlaties duider niet op de aanwezigheid van müticollineariteit. Ook binnen de afzonderlijke deelgroepen komen de cortelatiecoefficiënten niet boven de 35 .

Tabell 6.28_Pearson correlatiecoefficienten voor attractiviteit, overstapkosten en vertrouwen

\begin{tabular}{|c|c|c|c|}
\hline & WePrifronten & oversupkosten & atracturitent \\
\hline vertoumel. & - & 424 & 447 \\
\hline overshapkosten & -.06 & - & 429 \\
\hline attractiviteit & $.17 \%$ & $.20 * *$ & - \\
\hline
\end{tabular}

Beneden de diagonaal stan de correlaties vemeld, boven do dagonaal het aantal cases

Op basis van de wariabelen vertrouwen, attractiviteit en overstapkosten worden vervolgens twee additieve functies voor relatiesterkte opgesteld ${ }^{18}$, voor elk van beide deelgroepen één.

\begin{tabular}{|c|c|c|c|c|}
\hline $\begin{array}{l}\mathrm{RC}_{\text {icidem }} \\
\text { (1-waarde:) }\end{array}$ & $\begin{array}{l}=.66 \\
\left(1.67^{n .8}\right)\end{array}$ & $\begin{array}{l}+.29 \text { Vertroumen } \\
\left(3.30^{* * * *}\right)\end{array}$ & $\begin{array}{l}+.28 \text { Attractiviteit } \\
\left(7.44^{* * * * *)}\right.\end{array}$ & $\begin{array}{l}+.22 \text { Overstapkosten } \\
(3.27 * * *)\end{array}$ \\
\hline beta-coefficient: & & .23 & .51 & .22 \\
\hline 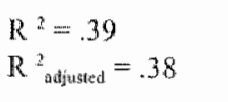 & \multicolumn{4}{|c|}{$F$-waardle $=29.78(p<0.001)$} \\
\hline $\mathrm{RC}_{\text {ax leduten }}$ & $=.29$ & +.27 Vertrouwen & +27 Altractiviteit & +.29 Oversiapkosten \\
\hline (t-waarde) & $\left(85^{\text {ns. }}\right)$ & 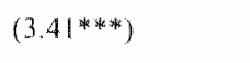 & $(6.42 * * *)$ & $(3.84 * * *)$ \\
\hline beta-coefficient: & & .23 & .45 & 26 \\
\hline 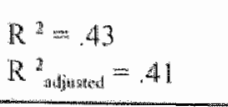 & \multicolumn{4}{|c|}{ F-waarde $=32.29(p<0.001)$} \\
\hline
\end{tabular}

De regressiccoefficienten zijn woor alle onalhankelijke variabelen positief. Overeenkomstig het in hoofdstuk 4 gepresenteerde model dragen "vertrouwen', 'overstapkosten' en 'attractiviteit" dus positicf bij an 'relatiesterkte'.

18 Er is geen reden interactie-effecten te verwachten: vanuit de beschikbare literatuur wordt daartoe geen aanleiding gegeven. De voorkeur gaat dan ook uit naar een eenvoudig lineair additief nodel. 
Naar aanleiding daarvan worden de hypothesen 3.1 (Hoe groter de attractiviteit voor de consument wan een relatie met een aanbieder, hoe groter de sterkte van de relatie (mate wan binding) met die aanbieder"), 3.2 ("De relatie is sterker naamate de consument hogere overstapkosten percipieert') en 3.3 ('Hoe groter het wertrouwen in de aanbieder, hoe sterker de relatie met die aanbieder') niet verworpen.

De verklaarde variantie $\left(\mathrm{R}^{2}\right.$ adiussed $)$ bedraagt $38 \%$ voor leden en $41 \%$ woor ex-leden. Dit impliceert dat op basis van de in de vergelijkingen opgenomen variabelen al een aanzienlijk deel van de variantie van $\mathrm{RC}$ verklaard kan worden.

Wordt gekeken naar welke variabelen het meest bijdragen tot het verklaren van de variantie in de afhankelijke variabele 'relatiesterkte', dan blijkt dat 'attractiviteit' zowell bij leden als bij ex-

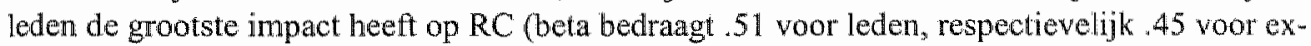
leden). Bij leden leveren vervolgens 'vertrouwen' (beta $=.23$ ) en 'overstapkosten" (beta $=.22$ ) een bijdrage to het verklaren van de variantie in $\mathrm{RC}$. Bij ex-leden is de situatie fets anders: daar volgen 'overstapkosten" (beta $=.26)$ en "vertrouwen' (beta $=.23$ ) als verklarende variabelen op enige afstand van de onafhankelijke variabele "attractiviteit". De bijdrage van de variabele 'overstapkosten' aan de verklaring van (de variantie in) RC wijzigt dus in de loop van de tijd. Het verschil in het relatieve belang van de afzonderlijke variabelem tussen de deelgroepen komt in zekere mate ook tot uitdrukking in een verschil in de regressiecoëfficiënten. Met namye de regressiecoëfficiënten van de variabele 'overstapkosten' vertonen een, statistisch gezien weliswaar niet significant ( $t$-waarde $=.66 ; p>.05$ ), verschil.

Gelet op de voorgaande resultaten kan gesteld worden dat de functies verschillen en dat een relatie een dynamisch proces is.

Hypothese 4 dient echter verworpen te worden: hoewel het relatieve belang van de invloedsvariabelen wijzigt in de loop van de tijd, gebeurt dat niet overeenkomstig het in hypothese 4 geschetste patroon.

Opwallend is dat de constante in de vergelijking voor zowel leden als ex-leden niet significant van de warde 0 verschilt en daarmee geen significante bijdrage levert aan de verklaring van RC. Gelet op de aard en inhoud van het wijnkaarthoudersprogramma van Gall \&. Gall, zoals beschreven in hoofdstuk 4, is het aamemelijk dat er geen sprake hoeft te zijn var een bepaald "basis- of minimumniveau" voor RC om het lidmaatschap aan te gaan danwel te contineren en daarmee de korting van 10\% op de wijnaankopen bij Gall \& Gall te verkrijgen. Om de kosten van het lidmaatschap terug te verdienen is het eerder aannemelijk dat een bepaald (minimum)niveau van RFM vereist is. Met andere woorden het is eerder aannemelijt dat "heavy users' lid worden van het wijnkaarthoudersprogramma dan mensen die reeds een bepaalde mate van binding met de aanbieder percipiëren. Immers, 'heavy users' hebben het meest profjut van het kortingwoordeel. 


\subsection{CONCLUSIE}

In dit hoofdstuk zijn de resultaten van de gegevensanalyse gepresenteerd. Op basis van de reswlaten van de gegevensanalyse kan ten amzien van de hypothesen het volgende verneld worden.

Hypothese 1 Juid:

"De relationship commitment questionnaire $(\mathrm{RCQ})$ is een betrouwbare en valide meetschaal woor het vaststellen van de sterkte wan relaties tussen een aambieder en zijn eindafinemers, i.c. consumenten."

De twee studies tonen aan dat deze hypothese niet verworpen kan worden. De meetschaal maakt het mogelijk het veronderstelde onderscheid tussen leden en niet-leden in termen van relatiesterkte te kwantificeren. Vanuit verschillende criteria is dit immers te onderbouwen. Zowel voor de Gulpener studie alls voor de Gall \& Gall studie werd een afdoende mate van interne validiteit geconstateerd op basis van de aanwezige face-validity en construct-validity. De interne-consistentiebetrouwbaarheid werd voor beide studies als voldoende beoordeeld. Dit betekent dat de relationship commitment questionnaire (RCQ) als een betrouwbare en valide mectschaal kan worden ingezet om de sterkte van relaties tussen een aanbieder en zijn eindafnemers ( $\mathrm{RC}$ ) te meten.

Bij deze algehele conclusie is een aantal kanttekeningen op zijn plaats.

1. Hoewel de responsepercentages zonder meer bevredigend zijn, is niet duidelijk in hoeverre de non-respondenten afwijken van de respondenten, aangezien een daadwerkelijke controle niet kon plaatsvinden. Wel is een aantall initiatieven genomen om het responsepercentage positief te beinvloeden. Daar waar resultaten relatief gebruikt worden speelt de mogelijk aanwezige non-response bias een minder relevante rol. De mogelijke aanwezigheid van non-response bias mag echter niet uit het oog verloren worden en plaatst een kritische kanttekening bij de conclusies (zoals bij elk onderzoek waarin non-response optreedt!).

2. Naast de non-response bias mag ook de mogelijk aanwezige selection bias op basis van item non-response niet genegeend worden. Nadere inspectie van de datasets heeft niet geleid tot identificatie van specifieke items die in dat opzicht systematisch voor problemen zouden kunnen zorgen. Een vergelijking van respondenten die in de analyses zijn meegenomen met de respondenten die niet in de analyses zijn meegenomen heef ten aanzien van koopgedragsvariabelen, belevingsvariabelen en achtergrondkenmerken nauwelijks of geen significante verschillen opgeleverd.

3. Relatiesterkte (RC) is beschonwd en behandeld als een unidimensioneel construct. Dit is in lijn met de wijze waarop in de organisatieliteratuur met (organizational) commitment wordt omgegaan. In de Gulpener studie werd dit uitgangspunt middels principale componenten analyse ondersteund. Dezelfie analyse leverde in de Gall \& Gall studie twee factoren op, die als 'emotioneel' an 'rationeel" zijn benoemd. Enerzijds wijst dit er op dat RC niet als een unidimensioneel construct beschouwd kan worden. Anderzijds duidt dit resultaat er op dat de RCQ als een generieke maatstaf woor RC gezien kan worden. Immers, RC meet de mate van binding, onafhankelijk van de vraag of deze binding voortkomt uit een rationele afweging van plus- en minpunten, of gebaseerd is op overwegend emotionele beweegredenen. Het is van belang te constateren dat bij de bepaling van $\mathrm{RC}$ beide typen van beweegredenen een rol spelen, dat RC de mate van binding meet en dat middels PCA 
nader inzicht wordt verkregen in de aard van de relatie. Op mogelijkheden de aard van de relatie nader te onderzoeken, komen we in hoofdstuk 7 terug. Blijkbaar is de relatie met Gall \& Gall op zowel emotionele als rationele motieven gebaseerd, terwijl de mate van binding met Gulpener overwegend vanuit emotionele beweegredenen gevoed wordt. Dit wordt ondersteund door de resultaten voortkomend uit het verklaren van relatiesterkte. Welk effect dit verschil in factoroplossingen heeft op de betrouwbatheid van de resultaten kan dus niet eenduidig aangegeven worden.

Hoewel deze aspecten (non-response bias en selection bias op basis van item non-response) in onze studie naar alle waarschijnlijkheid geen serieus probleem vormen met betrekking tot de betrouwbaarheid van de resultaten kan de mogelijke aanwezigheid ervan niet ontkend $0 . q$. genegeerd worden. Dat impliceert dat wij de hypothese, dat de relationship commitment questionnaire (RCQ) een betrouwbare en valide meetschaall is voor het vaststellen van de sterkte van relaties tussen een aanbieder en zijn eindafnemers, op basis van de huidige beschikbare resultaten weliswar niet verwerpen, maar dat we deze conclusies in het licht van bowenstaande kritische kanttekeningen moeten bezien.

\section{Hypothese 2 luidt:}

"Het koopgedrag (de loyaliteit) van een klani is eenduidig positief gerelateerd aan de sterkte van de relatie met de aanbieder zoals door de klant gepercipieerd."

Deze hypothese dient te worden verworpen. Dit geld dan met name woor functionalisten (combinaties van een goede, loyale klant en een zwakke relatie) en sympathisanten (combinaties van een minder goede klant en een sterke relatie). Relatiemarketing richt zich op het individu. En op het individuele niveau is geconstateerd dat het koopgedrag niet per definitie spoort met de sterkte van de relatie. Op individueel niveau voldoen gedragskenmerken dan niet als indicator voor relatiesterkte. De attitudecomponent en de gedragscomponent vertegenwoordigen wezenlijk verschillende dimensies in de onderzochte relaties.

\section{Hyporhese 3.I luidt:}

"Hoe groter de attractiviteit voor de consument van een relatie met een aanbieder, hoe groter de sterkte van de relatie (mate van binding) met die aanbieder."

Hypothese 3.2 luidt:

"De relatie is sterker naamate de consument hogere overstapkosten percipitert."

Hypothese 3.3 luidt:

"Hoe groter het vertrouwen in de aanbieder, hoe sterker de relatie met die aanbieder."

Hypothese 3.4 luidt:

"Er bestaat een positief verband tussen tevrechenheid over" de relatie met een aanbieder en het vertrouwen in die aanbieder."

De resultaten van zowel de Gulpener studie als de Gall \& Gall studie geven geen aanleiding deze hypothesen te verwerpen.

De hypothesen 3.1 to en met 3.3 werden getoetst aan de hand van een regressiemodel. Daarin waren de variabelen "attractiviteit", "gepercipieerde overstapkosten" en "Vertrouwen" 
opgenomen als verklarende variabeien voor 'relatiesterkte'. De variabele 'tevredenheid' was als antecedent van 'vertrouwen' opgenomen en werd geacht indirect, via 'vertrouwen', bij te dragen aan de verklaring van 'relatiesterkte'. De regressie-analyses leverden, overeenkomstig de hypothesen 3.1 tot en met 3.3, positicve verbanden op tussen 'relatiesterkte' enerzijds en "attractiviteit", 'gepercipieerde overstapkosten' en 'vertrouwen' anderzijds. De mate van multicollineariteit bleef binnen acceptabele grenzen zodat de positieve regressiecoëfficiënten als betrouwbaat gelden. Tevens bleek dat een aanzienlijk deel van de variantie in relatiesterkte verklaard kon worden door slechts een beperkt aantal onafhankelijke variabelen. Het opnemen van 'tevredenheid' als antecedent van 'vertrouwen' bleek gerechtvaardigd te zijn. In beide studies werd, overeenkomstig hypothese 3.4 , een significant positief verband aangetroffen tussen deze twee variabelen. Het opnemen van 'tevredenheid' als antecedent van 'relatiesterkte', naast de overige drie onafhankelijke variabelen, zou enerzijds multicollineariteit veroorzaken (de mogelijke toename in verklaringskracht zou dan misleidend zijn), terwijl anderzijds geen significante bijdrage aan de verklaring van RC wordt geleverd.

\section{Hypothese 4 luidt:}

"Het relatieve belang van de invloedsvariabelen wijzigt in de loop van de tijd, in die zin dat attractiviteit relatief de belangrijkste invloed heeft op relatiesterkte in de opbouwfase van de relatie. Vertrouwen zal relatief de belangrijkste invloedsvariabele zijn in de fase van voortzetting en versterking van de relatie. Overstapkosten zullen relatief de belangrijkste factor van invloed op relatiesterkte vormen bij de overweging de relatie te beëindigen."

Deze hypothese dient naar aanleiding van beide studies verworpen te worden. Weliswaar duiden de onderzocksresultaten er op dat een relatie een dynamisch proces is, echter de dynamiek verloopt niet volgens het geschetste patroon.

In de Gulpener studie zijn 'vertrouwen' en 'attractiviteit' de meest fundamentele verklarende variabelen, in die zin dat deze variabelen bij alle drie de deelgroepen een significante bijdrage leveren aan de verklaring van 'relatiesterkte'. 'Overstapkosten' doen dat alleen bij leden en exleden. Behalve dat 'overstapkosten' niet voor elke deelgroep een significante bijdrage levert,

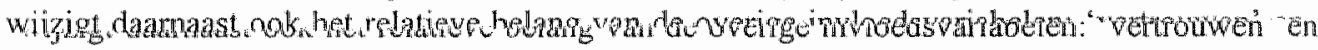
'attractiviteit'. Voor potentiële leden en leden levert 'vertrouwen' de meest significante bijdrage aan de verklaring van RC, gevolgd door 'attractiviteit'. Bij ex-leden is het omgekeerde het geval.

In de Gall \& Gall studie, waar twee deelgroepen nader werden onderzocht, spelen 'attractiviteil.", 'overstapkosten' en 'vertrouwen' zowel bij leden als ex-leden cen significante rol. Bij leden word de variantie in RC het meest verklaard door 'attractiviteit', op enige afstand gevolgd door 'vertrouwen' respectievelijk 'overstapkosten'. Bij ex-leden draagt de variabele "attractiviteit" eveneens het meest bij aan de verklaring van de variantie in RC, maar wordt hier gevolgd door de variabelen 'overstapkosten' respectievelijk "vertrouwen ${ }^{\text {19 }}$.

Een opvallende constatering is dat bij leden van het Gulpener Biergilde mogelijk een bepaald "basis- of minimumniveau" voor $\mathrm{RC}$ nodig is om lid van het Biergilde te worden danwel te

19 Hier wordt nogmaals opgemerkt dat er sprake is van cross-sectie studies en dat het derhalve niet mogelijk is geweest de ontwikkeling van consumenten in de tjjd daadwerkelijk te volgen. Zie ook voetnoot 13. 
blijven. Voor een dergelijk basisniveau bij wijnkaarthouders bestaat geen enkele indicatie, hetgeen gelet op (het verschil in) de aard en inhoud van beide programma's aannemelijk is.

Met deze bevindingen als uitgangspunt zullen in het volgende hoofdstuk conclusies getrokken worden ten aanzien van de in hoofdstuk 1 aangereikte onderzoeksvragen. Tevens zullen implicaties, die uit die conclusies voortvloeien, worden vermeld. Tot slot zullen in hoofdstuk 7 nog suggesties gedaan worden voor verder onderzoek. 


\section{HoOfDSTUK 7: CONCLUSIES, IMPLICATIES EN SUGGESTIES VOOR VERDER ONDERZOEK}

"We want to own consumers "hearts, not just heir pocket books."

Martin Levine, General Manager

Chrysler's Jeep Diwision

(in: Wall Street Journal, 23 mei, 1997)

\subsection{INLEIDING}

In dit hoofdstuk zal een terugkoppeling plaatsvinden watu de voor dit onderzoek geformuleerde onderzaeksvragen. Aan elke vraagstelling zullen conclusies en implicaties verbonden worden (\$7.2). Tevens zullen suggesties gedaan worden voor verder onderzoek op het terrein wan het meten en managen van klant-organisatie relaties $(\$ 7.3)$.

\subsection{CONCLUSIES EN IMPLICATIES TEN AANZIEN VAN DE ONDERZOEKS- VRAGEN}

In hoofdstuk 1 werd een drietal onderzoeksvragen geformuleerd. Aan de beantwoording van deze vragen zal nu aandacht worden besteed. Per vraag zullen de voomaamste conclusies en implicaties uiteengezet worden. In \$7.2.1 wordt stilgestaan bij het gebruik van de relationship commitment questionnaire (RCQ) als meetschaal voor relatiesterkte. In $\$ 7.2 .2$ wordt gekeken nat het gebruik van de RCQ in combinatie met koopgedraggegevens. $\$ 7.2 .3$ geeft weer middels welke factoren en strategieën relatiesterkte te beinvloeden is.

\subsubsection{CONCLUSIE EN IMPLICATIES BETREFFENDE HET METEN VAN RELATHESTERKTE}

Onderzoeksvraag 1 luidt:

"Welke gegevens geven een indicatie van de sterkte van een relatie tussen (eind)afmemer en aanbieder en welke daarvan kunnen worden gebruikt in operationele zin voor de samenstelling van een instrument voor het meten van de relatiesterkte?"

\section{Conclusie}

In $\$ 4.2$ werd een aantal indicatoren woor relatiesterkte geëvalueerd. Enkelvoudige cn meervoudige koopgedrags- en belevingsvariabelen werden als indicator in beschouwing genomen. Deze evaluatie leidde tot co conclusie dat relatiesterkte niet indirect, via indicatoren, mar direct gemeten dient te worden. Teneinde de sterkte van iemands identificatie met en betrokkenheid bij een organisatie te meten, werd de woorkeur uitgesproken voor het gebruik van de Relationship Commitment Questionnaire (RCQ) als meetinstrument. Dit instrument werd getoetst in een 'multiple study, multiple sample' onderzocksopzet. De theoretische uiteenzetting en de resultaten van het empirische onderzock leiden tot de conclusic dat hot domein van de Organizational Commitment Questionnaire (OCQ), die in de organisatie literatuur aangeduid wordt als een betrouwbaar en valide instrument om de binding tussen 
werknemers en werkgevers te meten, zinvol kan worden uitgebreid naar een marketingcontext, warin het opbouwen en onderhouden van rablates tussen consumenten en organisaties centraa! staan.

De RCQ voorziet daamee in een wetenschappelije en maatschappelijke behoefte aan een instrument om de sterkte van relaties te meten, zoals wit de theoretische en management implicaties mag blijken.

\section{Theoretische implicaties}

Relatiesterkte, zoals door ons gedefinieerd en gemeten, bleek voor aanzienlijke delen van het klantenbestand niet als zodanig in het koopgedrag (i.c. RFM) tot witing te konen. De Chikwadrat analyses duidden er op dat het verband tussen relatiesterkte en koopgedrag als zwak moet worden angemerkt, ook al is er sprake van een significant positief verband. Dit onderstrept het belang van het onderscheiden van een gedragsdimensie en belevingsdimensie binnen een relatie, zoals in hoofdstuk 2 uiteengezet is en in het RLM-model is toegepast. Ook wordt dammee bevestigd dat een klant die en sterke relatie percipieent, niet altijd gelijkgesteld kan worden aan cen goede klant. Onze resultaten zijn in hijn met recent USA-onderzoek, zoals het in hoofdstuk 4 aangehaalde onderzoek van Denize en Young (1996). Zij hebben commitment gemeten in de professionele dienstverlening: marketingmanagers die gebruik maken van de diensten van externe reclamebureaus, sales promotion organisaties of marktonderzoskbureaus. Hun commitment construct omvatte zowel een attitude component als een gedragscomponent. Zij concluderen dat de attitudecomponent en de gedragscomponent wezcnlijk verschillende dimensies vertegenwoordigen in de onderzochte relaties. Tevens concluderen zij dat commitment primair een attitude construct is en dat relatiesterkte het best gemeten kan worden door afnemers to vragen naar hun gevoelens ten aanzien van hun relatie met de aanbieder. Op basis var de resullaten van ons onderzoek sluiten wij ons bij deze conchusies van Denize en Young (1996) aan.

\section{Management implicaties}

De ontwikkeling van een attitudinal relationship commitment meetschaal biedt mogelijkheder om als hulpmiddel te voorzicn in de behoefte van managers tot het meten en monitoren van relalies met afnemers. De in ons onderzoek gepresenteerde en getoetste attitudinal relationship commithent questionnaire (RCQ) komt aan deze behoefte tegemoet en vooziet daannee in het booogde hulpmiddel voor managementdoeleinden. Een dergelijk tulpmiddel helpt aanbieders bij het differentieren van afnemers op basis van hun gepercipieerde relatiesterkte en daamee hun neiging on wens on de relatie voort te zeten. Investeringsbeslissingen betreffende marketingactiviteiten gericht op het versterken van relaties met afnemers kunnen daarmee meer strategisch onderbouwd worden, terwijl de marketingactiviteiten zelf efficiënter en effectiever kumen platsvinden. Daarbij kan gedacht worden aan beslissingen ten aanzien van het wel of niet introduceren wan een klantenclub respectievelijk aan direct marketingactiviteiten. Middelen kumnen worden ingezet om de relatiesterkte waar nodig en mogelijk te werbeteren. Wijzigingen in relatiesterkle kumen gemonitored worden waardoor de effecten van ondernomen marketingactiviteiten zichtbaar gemakkt worden. Ongunstige ontwikkelingen in relatiesterkte kumen geanalyseerd en vervolgens aangepakt worden. Daarmee zijn we inmiddels angekomen bij de beantwoording van de tweede onderzoeksvraag. 


\subsubsection{CONCLUSIE EN IMPLICATIES BETREFFENDE het GEBRUIK VAN DE RELATIONSHIP COMMITMENT QUESTIONNAIRE (RCQ)}

Onderzoeksvraag 2 luidt:

"(Hoe) kan het meetinstrument voor de relatiesterkte gebruikt worden voor het segmenteren, beschrijven en monitoren van relaties?"

\section{Conclusie}

De relationship commitment questionnaire (RCQ) is voldoende valide en betrouwlyar bevonden om relatiesterkte te meten. Verschillen in relatiesterkte, zoals deze verwacht werden te bestaan tussen verschillende consumentengroepen (leden versus niet-leden), werden door de RCQ in beide studies aangetoond te bestaan. Tevens is geconcludeerd dat binnen een relatie een gedragsdimensie en een belevingsdimensie onderscheiden kunnen worden. Daarop is ons RLM-model gebaseerd. Door de belevingsdimensie van dit RLM-model middels de RCQ te kwantificeren en deze dimensie te combineren met de gedragsdimensie kunnen relaties nader gesegmenteerd, beschreven en gemonitored worden.

\section{Theoretische implicaties}

Uit ons onderzoek is gebleken dat afnemers niet alleen op basis van hun (koop)gedrag, maar tevens op basis van hun gepercipieerde relatiesterkte gesegmenteerd kunnen worden. Het gebruik van dit niet-traditioneel segmentatiecriterium biedt nader inzicht in de samenstelling van het klantenbestand. In ons onderzoek is daarbij een verdeling gemaakt in vier segmenten. Deze segmenten verschillen significant van elkaar voor wat betreft koopgedrag (RFM) en/of relatiesterkte. Afnemers kunnen dan beschreven worden op basis van transactie-informatie enerzijds en de sterkte van hun relatie met de aanbieder anderzijds.

De vier groepen die in ons onderzoek onderscheiden zijn, kunnen als volgt beschreven worden: Sympathisanten. Deze klanten ervaren een sterke relatie met de aanbieder. Dit komt echter niet in hun koopgedrag tot uitdrukking. Zij onderhouden ook met alternatieve aanbieders (mogelijk sterke) relaties en brengen daar een deel van hun bestedingen onder. Dit kan zijn ondat zij als 'variety seekers' graag eens iets anders willen proberen. Ook kan het zijn dat zij gewoon niet veel te besteden hebben ('low-budget' kopers) en om die reden als economisch minder belangrijk geclassificeerd worden.

Vrienden. Deze afnemers ervaren een sterke relatie met de aanbieder en brengen dat middels hun koopgedrag tot uitdrukking. De aanbieder heeft een groot klantaandeel.

Kennissen. Kennissen voelen geen sterke band met hun aanbieder. Dit komt in hun koopgedrag tot uitdrukking: het merendeel van hun bestedingen brengen zij elders onder. Dit kan meerdere oorzaken hebben. Het is mogelijk dat de klant de relatie met de huidige aanbieder albouwt en zijn klandizie overhevelt naar een concurrerende aanbieder. Een andere mogelijkheid is dat de klant juist de mogelijkheden aftast om met de huidige aanbieder een relatie op te bouwen. Een derde mogelijkheid is dat kennissen als 'economy shoppers' of 'cherry pickers' opereren: gevoelig voor prijs stappen zij gemakkelijk van de ene aanbieder over naar de andere.

Functionalisten. Functionalisten ervaren eveneens geen of slechts een zwalke binding met de aanbieder. Toch vertegenwoordigen zijzelf voor de onderneming een hoge economische waarde. Mogelijk kopen zij met name om redenen van gemak, gewoonte of inertie, en stappen zij over naar de concurrentie indien deze hun interesse weet te wekken en een grote aantrekkingskracht op hen weet uit te oefenen. 
Door regelmatig (een representatieve steckproef wit) het klantenbestand in een RLM-model op te nemen, is het mogelijk wijzigingen in relatiesterkic (en/of koopgedrag) te monitoren en ongunstige ontwikkelingen in de samenstelling van de klantenportfollo te analyseren en aan te pakken.

Met het ontwikkelde meeinstrument kan een aanbieder de resultaten van strategische beslissingen om de binding met klanten te verbeteren, zoals in het geval van een klantenclub, monitorew, analyseren cn evalueren. Met behulp van het meetinstrument kan de aanbieder achterhalen wat het effect is van een klantenclub op relatiesterkte. Een klantenclub wordt in het algemeen gezien als een middel om de relatie met klanten te versterken (bindingseffect) en de loyaliteit in termen van koopgedrag te stimuleren (gedragseffect). Het waargenomen werschil in relatiesterkte en koopgedrag tussen deelnemers en niet-deelnemers wordt daarbij in het algemeen aan de klantenclub toegeschreven. Deze aanname ten aanzien van de bindings- en gedragseffecten van een klantenclub is echter nog nauwelijks empirisch gestaafd. Dit is met name het gevolg van het ontbreken van metingen vón rdat de klantenclub werd ingevoerd. De vraag is dan ook of die aanname terecht is. Immers, als gevolg van het selectie-effect van een klantenclub komt dit soort uitspraken in een ander daglicht te staan. Het selectie-effect houdt in dat "customers reveall their basically positive attitude towards the club-operator resp. towards the club concept by becoming a member of the club" (Diller, 1997b, p. 243; zie ook Hiolz, 1998). Vanuit dat oogpunt mag verwacht worden dat een clubprogramma (zoals het Gulpener Biergilde) díe consumenten selecteert die reeds een bepaalde (nate van) commitment hebben. De resultaten wan ons onderzoek naar de verklaring van relatiesterkte suggereren de aanwezigheid van dit selectie-effect in het geval van het Gulpener Biergilde ( $\$ 6.2 .5)$.

Een selectie-effect kan ook door een voordeelprogramma (als dat van Gall \& Gall) vervuld worden, maar dan niet op basis van het commitmentniveau, maar op basis van het gebruiksniveau (Diller en Frank, 1996; Sharp en Sharp, 1997; Holz, 1998). Immers, het mag verwacht worden dat 'heavy users' eerder/meer van het (korting)voordeel genieten dan 'light users", onafhankelijk van de mate van binding. "Heavy users" zullen dan eerder geneigd zijn deel te nemen aan het voordeelprogramma, aok indien lidmaatschapsgeid verschuldigd is bij deelname. "Heavy users" hebben deze vorm van contributie eerder terugverdiend dan "light users". De resultaten van ons onderzock bij Gall \& Gall naar de verklaring van relatiesterkte duidden reeds op de afwezigheid van een selectie-effect op basis van het commitmentniveau (86.3.5): noch bij leden, noch bij ex-leden werd cen "basisniveau" voor relatiesterkte aangetroffen. Wel blijkt uit de open vragen in het Gall \& Gall onderzoek dat én van de meest genoemde redenen om houder van de wijnkaart te worden is dat de respondent veel wijn koopldrinkt (tabel BI, bijlage 3). En de meest genoemde redenen om het lidmaatschap op te zeggen zijn dat de respondent te weinig gebruik gemaakt heeft van de wijnkaart en dat het lidmaatschap (daamee) niet langer rendabel is (tabel BI, bijlage 3). Dit duidt op de arawezigheid wan een selectie-effect op basis wan het gebruiksniveau.

Mogelijk was het verschil in relatiesterkte en/of koopgedrag er dus al voordat de klantenclub werd geintroduceerd. Het is namelijk te verwachten dat in het bijzonder die klanten tot de klantenclub toetreden die reeds een positievere instelling (een sterkere binding of een hogere koopfrequentie) hebben dan de klanten die niet tot de klantenclub toetreden. Omdat een vergelijking met de relatieperceptie en het koopgedrag van dezelfde twee afnemersgroepen voordat de klantenclub werd geintroduceerd veelal niet (meer) mogelijk is, door het ontbreken van een voormeting, kan de klantenclub zelf niet zonder meer als corzaak van dit verschi 
aangewezen worden. Juist het selectic-effect van een klantenclub kan de verklaring zijn voor het gemeten verschil in relatiesterkte en koopgedrag tussen deelnemers en niet-deelnemers. Met andere woorden: de klantenclub werkt als een soort magneet en maakt het mogelijk reeds aanwezige verschil in relatiesterkte en koopgedrag tussen klantengroepen expliciet, maar kan niet zonder meer als veroorzaker van dit verschil gezien worden (Diller en Frank, 1996; Diller, $1997 \mathrm{a} ; 1997 \mathrm{~b} ;$ Holz, 1998). Indien daarnaast ook nog vastgesteld kan worden dat nieuwe leden, voor wat betreft relatiesterkte respectievelijk koopgedrag, niet significant verschillen van de reeds langer gevestigde leden, en er dus niet of nauwelijks sprake is van een bindingseffect respectievelijk gedragseffect ${ }^{1}$, dan ontbreekt de strategische onderbouwing woor de aanname dat een klantenclub een middel is om de relatie met klanten te versterken (bindingseffect) en de loyaliteit te stimuleren (gedragseffect). Sharp en Sharp (1997) en Dowling en Uncles (1997) concluderen dat loyaliteitsprogramma"s niet in staat zijn het reeds bestaande koopgedragpatroon van klanten fundamenteel te wijzigen. Diller (1997a; 1997b) en Schijns $(1998)^{2}$ stellen dat klantenclubs de relatie tussen aanbieder en clubleden niet significant versterken. Dowling en Uncles (1997) zijn dan ook van mening dat "customer loyalty programs seem to have been adopted too quickly, without much thougth" (p. 81).

\section{Management implicaties}

Door relatiesterkte regelmatig bij de klant te meten ontstaat inzicht in de effecten van genomen marketingmaatregelen op de relatiesterkte zoals klanten deze beleven en kan geanalyseerd worden in hoeverre de organisatie er in is geslaagd haar strategische doelstellingen ten aanzien van relatieversterking te realiseren. Door de combinatie met interne data op het gebied van koopgedrag ontstaat een beeld van de samenstelling van het klantenbestand en de ontwikkeling daarin. Het RLM-model helpt het management van de onderneming:

- inzicht te krijgen in de huidige samenstelling van haar klantenbestand op basis van feitelijk koopgedrag en gepercipieerde relatiesterkte;

- de effecten van strategieën en activiteiten (alsmede die van haar concurrenten) op koopgedrag en relatiesterkte te meten en te analyseren;

- maatwerk te bieden in aanbod, boodschap en medium, met andere woorden een gedifferentieerde klantbenadering te implementeren.

Het analyseren van het selectie-effect, bindingseffect en gedragseffect van een klantenclub heeft eveneens belangrijke implicaties voor het marketingbeleid.

Ten eerste ontstaat als gevolg van het selectie-effect een platform met klanten die een positieve houding hebben ten aanzien yan de organisatie en voor communicatie open staan en zelf tot

1 Met bindingseffect respectievelijk gedragseffect wordt hier bedoell dat de relatiesterkte respectievelijk het koopgedrag van leden zich significant positief ontwikkelt in de loop van de tijd (c.q. het lidmaatschap). Het kan immers niet uitgesloten worden dat door deelname aan het programma de relatiesterkte respectievelijk het koopgedrag (verder) verbetert (Diller en Frank, 1996).

${ }^{2}$ Op basis van exploratieve analyses toegepast op de data van Gulpener en Gall \& Gall stelt Schijns (1998) vast dat de relatiesterkte niet significant toeneemt, gedurende het lidmaatschap: de relatiesterkte die nieuwe leden percipiëren wijkt niet significant af van de relatiesterkte gepercipieerd dooi" leden die reeds gedurende meerdere jaren lid zijn. Resultaten wan soortgelijke analyses toregepast op koopgedraggegevens (RFM) duiden er op dat ook het koopgedrag niet significant verschilt tussen nieuwe leden en leden die reeds meerdere jaren lid zijn. 
communicatie overganbereid zijn. Voordeel van de klantenclub is dan ook dat de aanbieder mevir mogelijkheden heeft de leden op individueel niveau better te leren kennen en zijn marketingactiviteiten te baseren op de kennis die hij verkrjgt van de individuele klanten (Holz, 1998). In \$3.5.2 werd al opgemerkt dat het verdedigen van marktaandeel met behulp van informatie die via de (leden van) de klantenclub beschikbaar komt en die niet voor concurrenten beschikbaar is, effectiever lijkt te zjjn dan vormen wan themareclame waarin het merk telkens weer onder de aandacht wordt gebracht wan de massa. Dit word aok wel het 'know-how' effect genoemd (Diller, 1997a; 1997b; Schins, 1998). Daamee kan de aanbieder (alsnog) een positieve bijdrage leveren aan de relatiesterkte en het koopgedrag. De marketingactiviteiten worden daarmee effectiever".

Ten tweede ontstat als gevolg van het selectie-effect de mogelijkheid de communicatie efficiënter te laten verlopen. Er ontstaan lagere kosten als gevolg van minder 'waste' en/of verhoudingsgewijs hogere opbrengsten als gevolg vain het doelmatiger communiceren. De binding wordt individueler en duurzamer waardoor een dreigend klantenverloop eerder voorkomen kan wotỏen. En een kleiner verlies (aan klanten) resulteert in een grotere (financiale) winst (Reichheld en Sasser, 1990; Reichheld, 1996).

Een klantenclub is echter geen garantie dat een zwakke relatie in een sterke omslaat, of een slechte klant in een goede klant (Diller en Frank, 1996). Zoals in \$2.5.4 reeds naar voren kwam: voorwaarde is dat het kemprodukt concurrerend is, met andere woorden: indien de kwaliteit van het produkt en/of de prijsstelling niet concurrerend zijn, dan zal ook een klantenclub niet altijd in staat zijn de gevolgen van de ontstane ontevredenheid te neutraliseren. Kortom: klantenclubs kunnen wèl positief bijdragen aan het beeld dat consumenten van een aanbieder hebben., echter zij kunnen een minder gunstig beeld niet compenseren (Blijenberg et al., 1996). Dat klantenclubs de sleutel tot klantenbinding vormen (Buigholt et al., 1996a) dient dan ook genuanceerd te worden: een goede klant of sterke relatie is eerder een voorwatarde voor deelname aan de klantenclub (voordeelprogramma respectievelijk clubprogramma) dan het gevolg van die deelname.

Het belang van een strategische onderbouwing van de beslissing een klantenclub te introduceren wordt daarmee onderstreept. Marktonderzoek vóor introductie van een klantenclub kan belangrijke input leveren voor die strategische onderbouwing, onder andere met betrekking tot het specifieke doel dat met de klantenclub wordt nagestreefd en de hastbarheid van dat doel. Relatienarketingprogramma"s (waaronder klantenclubs) hebben nanclijk als belangrijk nadeel dat ze kostbaar en moeilijk te stoppen zijn (Blijenberg et al., 1996). Juist daarom is het van belang voordat een relatiemarketingprogramma wordt gestart een zo goed mogelijk inzicht te hebben in de mogelijke effecten van het beoogde programma.

3 Hier kan gelijk ook ean mogelijke werklaring liggen voor het resultat dat een klantenclub nauwelijks/niet bijclaagt an de (reeds) bestaande binding of koopgedrag. Ten eerste kan het zijn dat er (nog) manwelijks gebruik wordt gemaakt van de mogelijkheden on klanten/leden op individueel niveau beter le leren kennen en deze kennis structureel in een database wast te leggen, danwel (ten tweede) wordt er (nog) te weinig gebruk gemaakt van de verkregen kennis van de individuele klant om daarop de narketingactiviteiten te baseren. Verder kan het ook zijn dat de mogelijke functies die een kaart biedt niet (volledig) benut worden. In geval. van Gulpener en Gall \& Gall bijwoorbeeld vervullen de kaarten slechts een identificatie-/registratiefunctie en, met name in het geval van Gall \& Gall, ook een kortingsfunctie. Juist een betaal- en/of kredietfunctie (zoals bij de Bijenkorf Vaste Kantenkaart, de Auto Card van Kwik-Fit en de ANWB-kaart), in combinatie met een spaar-en kortingstunctie, kan wezenlijk bijdragen aan de omzet (Versteeg, 1996b). 
Die effecten zijn volgens Blijenberg et al. (1996) echter moeilijk vast te stellen. Ons onderzoek toont aan dat de effecten van relatiemarketingprogramma's in temen van gedrag en relatiesterkte wel degelijk zijn vast te stellen en dat die effeeten mogelijk overschat worden. De vraag is echter of zij ex-ante goed kumnen worden ingeschat. Dat geldt echter voor veel onderzoek naar nieuwe produkten en diensien en onderzoek naar de effecten van reclamecampagnes. Ondertussen zijn daar wrij betrouwbare technieken voor ontwikkeld, zoals quasi experimentele onderzoeksopzetten (waaronder de (meervoudige) tijdreeksopzet, De Pelsmacker en Van Kenhove, 1994; Churchill, 1995; Malhotra, 1996).

\subsubsection{CONCLUSIE EN IMPLICATIES BETREFFENDE HET BEINYLOEDEN VAN RELATIE- STERKTE}

De derde onderzoeksvraag luidt als volgt:

"Welke factoren spelen een rol bij het verklaren van relatiesterkte?"

\section{Conclusie}

Relatiesterkte bleek in ons onderzoek voor een aanzienlijk deel (38 tot $52 \%$ verklaarde variantie) verklaard te kunnen worden uit een beperkt aantal belevingsvariabelen, i.c. vertrouwen, attractiviteit en overstapkosten. Daardoor wordt een beter inzicht verkregen in de factoren die invloed uitoefenen op relatiesterkte en ontstaat de mogelijkheid deze factoren te beïnvloeden en daarmee de relatie te versterken.

\section{Theoretisclie implicaties}

Veel van het empirische en theoretische onderzoek naar verklarende factoren voor relatiesterkte is uitgevoerd binnen de vakgebieden industriële marketing (o.a.: Wilson en Mummalaneni, 1988; Wilson, 1990; 1995; Morgan en Hunt, 1994) en dienstenmarketing (o.a.: Crosby en Stephens, 1987; Crosby et al., 1990; Venetis, 1997). Voor wat betreft de invloed van de variabelen vertrouwen, attractiviteit en overstapkosten op de sterkte wan relaties, blijken de ervaringen en bevindingen binnen de vakgebieden industriële marketing en dienstenmarketing overdraagbaar naar het vakgebied consumentenmarketing. Dit impliceert dat deze factoren beschouwd kunnen worden als factoren die in het algemeen bijdragen aan de verklaring wan relatiesterkte, en zich niet beperken tot specifieke toepassingen.

Dit is een belangrijke constatering omdat de vraag naar de factoren achter relatiesterkte ook in consumentenmarkten bijzonder actueel is geworden. Zo is de automatische gebondenheid van verplicht verzekerden met de vroegere ziekenfondsen in de eigen regio vervallen en zijn er nieuwe aanbieders op de markt voor zorgverzekeringen verschenen (Van Nes et al., 1998). Dergelijke ontwikkelingen zijn ook waameembaar op het gebied van overheidsdiensten. Diensten als openbaar vervoer, die in het verleden exclusief waren voorbehouden aan overheidsinstellingen, worden geprivatiseerd en door nieuwe partijen op de markt aangeboden. De automatische 'keuze' van de consument verandert in een keuze uil verschillende alternatieven. In dergelijke situaties is het van doorslaggevende betekenis te weten op basis van welke factoren klanten behouden kumnen worden.

\section{Management implicaties}

De factoren die van invloed blijken op de sterkte van relaties zijn met name van belang voor het managen van relaties. Met name in geval wan een strategie gericht op relatieversterking heeft de marketingmanager er baat bij te weten welke factoren daarbij een rol kunnen spelen. 
Relatieversterking is ển van de ontwikkelingstichtingen die in het RLM-model onderscheiden kumnen worden. Elk van de vier onderscheiden groepen (sympathisanten, vrienden, kennissen en functionalistenj kan gedifferentieerd benaderd worden zodat de efficiency alsook de effectiviteit van de marketinginspanningen vergroot worden. Voor bestaande klanten betreft het de volgende benaderingen (zie figuur 7.1 ):

- klantbehoud;

- Kantontwikkeling;

- relatieversterking; $\mathrm{en}$,

- oogsten en desinvesteren.

Klanbehoud. Vrienden zijn van groot belang voor de organisatie. Zij bepalen vooral de "goodwill" wan een organisatie". Het is dus zonder meer zinvol deze vrienden voor de organisatie te behouden. Klantbehoud komt neer op het (blijven) stimulerea vam herhalingsaankopen enerzijds en het (blijven) voorzien van, bij voorkeur op de individuele Klant afgestemde, informatie anderzijds (Floor en Van Raaij, 1993; Blijenberg et al., 1996). Dit moet resulteren in echte loyaliteit (Bloemer, 1993a; Dick en Basu, 1994) oftewel in een op binding gebaseerde relatie. Het is zaak de uittredingsbarrières voor deze klanten te verhogen en hen daarmee af te schermen voor de concurrentie. Zo zal een klant die bereid is te investeren in hard- en software teneinde voortaan electronisch te bankieren, minder smel overstappen naar een andere financiële dienstverlener. Hij zal eerder zoveel mogelijk financiële zaken bij zijn huidige bank onderbrengen teneinde zijn investering zo snel mogelijk rendabel te laten zijn.

Klantontwikkeling. Dit komt neer op het beînvloeden van het koopgedrag, niet alleen in absolute zin (bijvoorbeeld een hogere waarde voor RFM) maar bovenal in relatieve zin (een groter aandeel in de bestedingen van de klant). Getracht kan worden de bestedingen per klant op te voeren: bestaande klanten worden aangespoord om grotere hoeveelheden van hetzelfde produkt ("deep selling") of om andere produkten ("cross-selling") aan te schaffen. Met name cross-selling (het aanbieden van een portfolio van produkten) kan aan de wens van de "variety seekers' tegemoel komen. Daarnaast kan produktgebruik gestimuleerd worden door nieuwe gebruiksmomenten of -mogelijkheden te creëren ("up-selling") (Floor en Van Raaij, 1993; Blijenberg et al., 1996). In geval van een relatiemarketingprogramma waarbij gebruik wordt gemaakt van cen kaart is het koopgedrag mogelijk ook te verbeteren door een spaar- en kortingsfunctie en/of een betal-en krediethunctie aan de (lidmaatschaps)kaart toe te kennen (Versteeg, 1996b). In het algemeen ligt de nadruk op het aanbieden van materiele beloningen ("hard benefits"), waarmee de aanbieder tevens blijk geeft de klant te waarderen. Daarmee wordt dan mogelijk ook de (i.c. financiële) binding (verder) versterkt.

Relatieversterking. Hier gaat het primair om het verbeteren van de binding (commitment) van de klant met de organisatic, zodat de 'short-list' ('evoked set") met leveranciers verkort wordt en de organisatie mogelijk zelfs de exclusieve leverancier wordt. Ook via relatieversterking kan de aarbieder dus het klantaandeel beinvloeden. Naast de mogelijke materiele beloningen zijn het hier met name de immaterielle voordelen ('soft benefits') die een rol spelen bij een verdere

* Blommaert en Blommaert (1986) spreken van 'goodwill' indien door bijwoorbeeld reclame en service ondernemingen in de loop van de tijd een goede nam verkrijgen. Hierdoor ontstaat binding met klanten op basis waarwan het mogelijk is neer winst te maken dan zonder die goede naam het geval zou zijn. Betaalde 'goodwill' mag bij overname op de gepubliceerde balans geactiveerd worden. Het vormt dan een immaterieel actief waarop afgeschreven wordt. 
intensivering van de relatie. Attractiviteit, vertrouwen en overstapkosten zijn factoren waxrwan gebleken is dat zij de relatiesterkte positief beinvloeden ${ }^{5}$. Door her (verzamelen en) verschafen van informatie middels directe, persoonlijke en open tweerichtingscommunicatie over (de behoefte aan): extra dienstverlening, produkten, speciale aanbiedingen, speciale "events", persoonlijk advies, referenties en het naar voren brengen van de overeenkomsten tussen de aanbieder en de afnemer, wordt het vertrouwen bij de klant versterkt, wordt de klant in zijn keuze bevestigd en worden uittredingsbarrières opgeworpen. Ook kan via het creêren van tevredenheid thet vertrouwen bij de klant positief beinvloed worden: door verbeterde uitkomsten uit de relatie en/of het via communicatie beïnloeden van de verwachtingen bij de klant, kan tevredenheid aangestuurd worden. Het verstrekken van adviezen en het zorgen voor een uitgebreid, afwisselend, en/of uniek assortiment verhoogt de attractiviteit van de anbieder In essentie komt het er op aan de klant ervan te overtuigen dat de aanbieder niet enkel interesse heeft in het winstpotentieel van de klant, maar ook in de persoon achter het klantnummer en de klant als individu te (h)erkennen en te behandelen, onder andere door de klant met zijn naam aan te spreken, de tijd voor de klant te nemen en hem geen diensten te verkopen waaraan hij geen behoefte heeft (Geyskens en Steenkamp, 1997).

Oogsten alvorens te desinvesteren. Van kennissen die mogelijk in de zogenaamde verzadigingsfase van de RLC zitten, zelf niet rendabel zijn noch rendabel gemaakt kunnen worden en dus geen potentieel meer vertegenwoordigen om uit te groeien naar functionalisten (klantontwikkeling) of vrienden (relatieversterking), dient op gepaste wijze afscheid genomen te worden. Bijvoorbeeld met een bedankje voor het in de organisatie gestelde vertrouwen, met een aanwijzing dat de organisatie niet bij uitstek geschikt is voor een adequate vervulling van de behoeften van de klant en een verwijzing naar een andere organisatie die daar mogelijk beter toe in staat is.

Bij sympathisanten die geen potentieel hebben om naar een vriend of functionalist uit te groeien (klantontwikkeling) kan owerwogen worden hier weinig/minder marketingactiviteiten op te richten in een poging ze (alsnog) rendabel te maken of rendabel te houden. Dit vereist veelal gewijzigde methoden wan 'cost accounting', zoals 'Activity Based Costing (ABC)' en 'Customer Based Accounting (CBA)' (Burgers, 1997). ABC en CBA zijn methoden van 'cost accounting" die er op gebaseerd zijn kosten en opbrengsten toe te rekenen aan de klant of de kllantactiviteit die ze veroorzaakt en niet aan het produkt dat wordt geproduceerd en verkocht. Bovendien dient het oogsten en desinvesteren met de nodige voorzichtigheid to gebeuren daar sympathisanten via positieve mondreclame ('referral markets', Christopher et al., 1991; Payme et al., 1995) een belangrijke indirecte waarde kunnen vertegenwoordigen. De indirecte warde van deze referenten (vaak professionele adviseurs als artsen, advocaten, architecten, bankmanagers en accountants, maar ook bestaande tevreden klanten) kan door het aanbrengen van nieuwe klanten het veelvoudige zijn van de directe waarde terwijl de indirecte waarde niet in de (eigen) RFM-waarde tot uitdrukking komt. Zouden dit soort 'advocates' uitsluitend op hun eigen RFM-waarde beoordeeld en overeenkomstig benaderd worden dan bestaat het gevaar dat deze benadering niet overeenkomt met hun verwachtingen en dat hun gevoelens van

\footnotetext{
${ }^{5}$ Door in ons model relatiesterkte afhankelijk te stellen van genoemde variabelen is inzicht verkregen in de verklarende factoren van relatiesterkte. Deze factoren verschaffen de ambieder mogelijkheden om een sterkere relatie met de afnemer op te bouwen. Daarbij dient de aanbieder zich af te vragen of die mogelijkheden al dan niet wia een relatiemarketingprogramma (zoals een klantenclub) worden aangeboden.
} 
onrechtvaardigheid toenemen. Dit schaadt hun relatieperceptie en kan op den duur tot afhaken leiden (wammee dan ook hun indirecte waarde verloren gaat).

Natat het managen wan bestaande retaties dient ook aandacht besteed te worden aan het werven wan nieuwe klanten waarmee relaties kunnen worden opgebouwd, oftewel acquisitie. Immers, klanten verbreken relaties ook op eigen initiatief, hetzij uit vrije wil danwel noodgedwongen. Het onvermijdelijke verlies aan klanten dient gecompenseerd te worden. Acquisitie is een activiteit die met name middels (sales) promotion instrumenten bewerkstelligd kan worden, zoals het aanbieden van aantrekkelijke kortingen teneinde consumenten over te halen tot een probeeradikoop of Jidmaatschap. Naast sales promotions kunnen ook de introductie van een nieuw produkt, merk of nieuwe winkel nieuwe klanten opleveren. Het komt er dus op neer de potentiele klant cen aantrekkelijk aanbod te doen teneinde de toetredingsdrempel te verlagen.

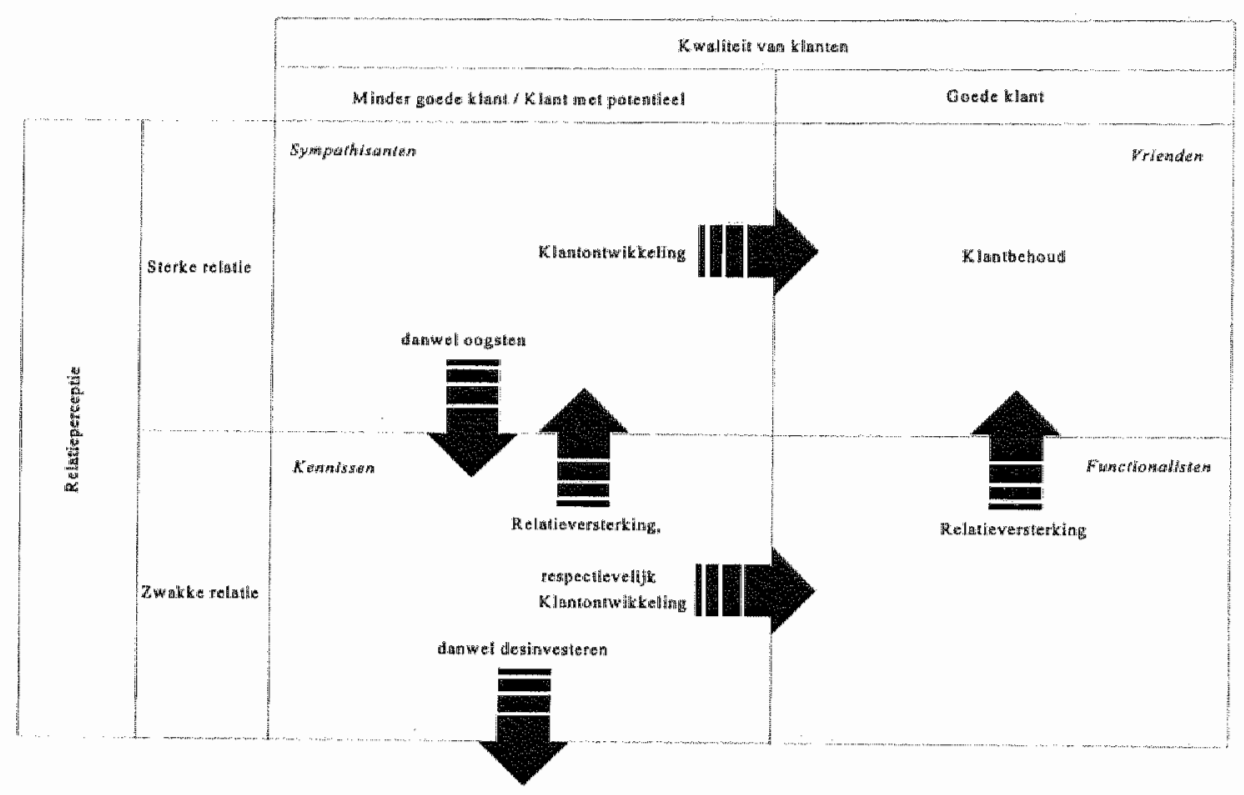

Figuur 7.1 Managenent implicaties voortvloeiend uit het RLM-model (Mede gebaseend op: Blijenberg et al., 1996, p. 1.2)

Met betrekking tot de vraag hoe Gulpener en Gall \& Gall de relaties met hun consumenten/leden kunnen versterken, blijkt uit de resultaten (met name met betrekking tot hypothese 4) dat de relaties verschillend van aard zijn. De relaties met leden en potentielle leden van het Gulpener Biergilde kumen als vertrouwensrelatie aangemerkt worden. Vertrouwen is volgens de in hoofdstuk 6 vermelde beta-coëfficiënten de grootste verklarende factor van de variantie in relatiesterkte. Attractiviteit is relatief de grootste verklarende factor van de variantie in relatiesterkte in geval van relaties met ex-leden van het Gulpener Biergilde alsmede in geval van relaties met leden en ex-leden van het Gall \& Gall wijnkaarthoudersprogramma.

De aard van de relatie hangt af van de reden waarom ze voortgezet wordt (Young en Denize, 1995). Dit impliceert dat leden en potentiële leden van het Gulpener Biergilde met name om 
redenen van vertrouwen de relatie met hun aanbieder voortzetten. Dit in vergelijking met de overige respondenten die niet alleen om redenen van vertrouwen, maar veeleer om redenen van attractiviteit de relatie voortzetten. Naast het gegeven dat de relatie tussen respondenten en Gall \& Gall met name gebaseerd is op het geboden assortiment en de adviesverlening (twee aspecten van attractiviteit) blijkt dat de relatie ook in financieel opzicht "attractief' is. Uit de open vragen is namelijk gebleken dat de voornaamste reden om deel te nemen aan het wijnkaarthoudersprogramma voortkomt uit de kortingen en aanbiedingen, kortom de financiele beloningen, die geboden worden. Het niet (langer) gebruik kunnen maken wan deze beloningen is de voornaamste reden om het lidmaatschap op te zeggen (zie voor een rubricering van de antwoorden op de open vragen bijlage 3). Ook op basis van de CFA werd gesuggereerd dat de relatie met Gall \& Gall naast emotioneel, vooral ook rationeel geladen is. Gesteld kan worden dat de relatie met Gall \& Gall primair gebaseerd is op directe, rationele voordelen, de zogenaande "hard benefits" (Barlow, 1992): voordelen die direct ervaren worden (prijs, adwies, assortiment). In termen van Berry en Parasuraman (1991) en Berry (1995) sluit deze bevinding het beste aan bij de financiêle binding, die ook het meest gevoelig is voor switchen. De classificatie van het Gall \& Gall wijnkaartprogramma in hoofdstuk 3 als een voordeelprogramma, dat primair een financiële binding creëert en vooraleerst het koopgedrag positief beoogt te beïnvloeden door het verstrekken van voordelen (beloningsstrategie), wordt daarmee op basis van de resultaten van ons onderzoek bevestigd. Gelet op de vertrouwensrelatie die Gulpener heeft opgebouwd met de potentiële leden en leden is daar de term sociale binding het meest van toepassing. Ook hier bevestigen de resultaten van ons onderzoek de classificatie in hoofdstuk 3 van het Gulpener Biergilde als een clubprogramma dat expliciet is gericht op het versterken van de sociale binding met haar leden. De positieve invloed op het koopgedrag wordt daarbij veeleer gezien als een (ontvangen) beloning door de klanten voor dit streven.

Worden beide klantenclubs ten opzichte van een geïntegreerd relatiemarketingprogramma gepositioneerd, op basis van emotionele en rationele clubvoordelen (Diller en Frank, 1996), dan levert dat figuur $7.2 \mathrm{op}$. 


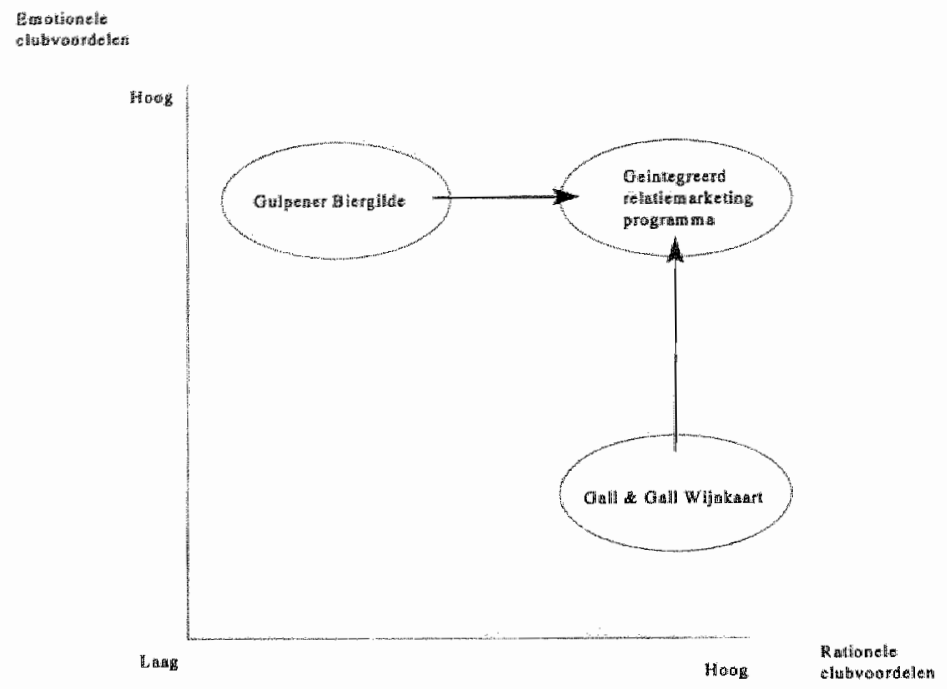

Figuur 7.2 Positionering van het Gall \& Gall wijnkaarthoudersprogramma (voordeelprogramma) en van het Gulpener Biergilde (clubprogramma) ten opzichte van een geïntegreend relatiemarketingprogramma op basis van emotionele en rationele clubvoordelen.

(Mede gebaseerd op: Diller en Frank, 1996)

Eerder werd er op gewezen dat het potentieel concurrentievoordeel in geval van financiële binding zwak is. De middelen die tot deze financiele binding moeten leiden zijn makkelijk te imiteren en verliezen verhoudingsgewijs snel hun relatieve aantrekkingskracht. Met andere woorden: het deelnemen aan een voordeelprogramma zal minder duurzaam zijn dan de deelname aan een clubprogramma. De resultaten van ons onderzoek verschaffen hiervoor enige atnwijzing. Terwijl Gulpener leden gemiddeld zo'n 4,5 jaar lid zijn van een programma dat op het moment van meting (eind '95) pas vijf jaar op de markt was (77\% van de huidige leden is vanaf het begin lid), zijn wijnkaarthouders op het moment van meting (begin "96) gemiddeld drie jaar lid van een programma dat al veel langer dan vijf jaar op de markt is.

Wil een organisatie de binding met haar afnemers/leden een bredere basis verschaffen dan alleen een financiele, dan dient relatiesterkte positief beinvloed te worden. Gall \& Gall zou dan ook meer moeten bieden/doen dan alleen op prijs concurreren. Gall \& Gall zou zich tevens kunnen richten op het creëren van sociale binding waarbij afnemers/leden (ook) iets anders geboden wordt dan (alleen) financiële voordelen.

Gulpener daarentegen baseert de binding met haar afnemers/leden nauwelijks op financiële gronden. Gulpener laat daarmee mogelijkheden, om het koopgedrag (en het ledenaantal) 
actiever te beinvloeden, liggen. Behalve het aanbieden van 'hard benefits' liggen er voor Gulpener echter ook nog mogelijkheden om via "soft benefits" de afmemers/leden sterker te binden en het verloop onder de leden te reduceren. In hoofdstuk 6 werd, met name op basis van onderzoek verricht door Tillemans (1998), reeds aangegeven dat (ex-)leden een aantal gezamenlijke activiteiten, waarbij contacten met andere leden gelegd kunnen worden, missen, en dat zij in een vroeg stadium geïnformeerd willen worden over nieuwe produktintroducties. Door zowel emotionele als tationele clubvoordelen te bieden en daarmee zowel financiele als sociale binding te creëren ("level two relationship marketing", Berry en Parasuraman, 1991) kunnen beide organisaties tot een geintegreerd relatiemarketingprogramma komen. Een dergelijk programma kan worden gezien als een mix van de "carrot'-methode en de "cuddle" methode (Kroezen, 1998). De carrot-methode houdt in dat de klant materieel word: beloond voor het gewenste gedrag. De carrot-methode leidt tot het kopen wan loyaliteit zonder dat er sprake is van een groter commitment. $\mathrm{Bij}$ de cuddle-methode (er)kent het bedrijf de klant en toont haar waardering aan de klant middels een voorkeursbehandeling. De beste voorbeelden van geintegreerd relatiemarketingprogramma's zijn te vinden in de luchtvaartbranche, waar 'hard benefits' (frequent flyer miles) en 'soft benefïts' (speciale check-in balie, gebrutk van de lounche) gecombineerd worden (Kroezen, 1998).

Daarmee leggen zij de basis voor het realiseren van een concurrentievoordeel middels duurzame relatievorming. Buttle (1996, p. 1) zegt hierover: "Enduring relationships with customers cannot be duplicated by competitors, and therefore provide for a umique and sustained competitive advantage."

\subsection{SUGGESTIES VOOR VERDER ONDERZOEK}

\subsubsection{SUGGESTIES TEN AANZIEN VAN DE RCQ}

Binnen de context van onze studie, leveranciers van niet dumrzame consumentengoederen (i.c. bier en wijn) die een klantenclub hebben opgezet, zijn de conclusies ten aanzien van de drie onderzoeksvragen naar onze mening generaliseerbaar. In een "multiple study, multiple sample" onderzoeksbenadering blijkt de RCQ als een betrouwbaar en valide meetinstrument naar voren te komen. Toegepast in het RLM-model leidt dit tot consistente patronen in de relatieportfolio. Het is echter van belang de attitudinal relationship commitment questionnaire ook te valideren door het in diverse andere branches toe te passen. Daarbij kan gedacht worden aan toepassingen in geval wam duurzame consumentengoederen en diensten. Initiatieven zijn inmiddels genomen in de branche voor lichaamswerzorgingsprodukten, in de financiele dienstverlening, alsmede in de charitatieve branche, teneinde de externe validiteit en generaliseerbaarheid en dus de stabiliteit van onze huidige bevindingen te beoordelen en te verbeteren ${ }^{6}$.

Scholtens (1996) paste de RCQ toe om te onderzoeken of er een positief verband bestond tussen relatiesterkte en de mate waarin consumenten bekend waren met de filantropische

\footnotetext{
6 Voor de toekomst worden meer onderzoeken verwacht daar het marktonderzoekbureau Research and Marketing b.w. het meetimstrument onder de naam RLM-monitor ${ }^{\mathrm{TM}}$ in haar assortiment heef opgenomen. Ook The Direct Branding@ Company, een onafhankelijk strattegisch adviesbureau op hel gebied wan merkenbouw en -exploitatie, makkt gebruik van het meetinstrument onder de naam Direct Brandinge Qualifier.
} 
activiteiten van een retailer in lichaamswerzorgingsprodukten. Dat verband bleek er inderdaad te zijn.

Muters (1997) constateerde geen significant verschil in relatiesterkte tussen gebruikers en nietgebruikers van een informatietechnologisch produkt (i.c. electronisch bankieren) onder particuliere cliènten yan een financiële dienstverlener.

Biemans (1997) stelde een verschil in relatiesterkte vast tussen donateurs van verschillende donateursprogramma's van een charitatieve instelling. Supporters van het duurdere en meer ingrijpende programma voelden zich sterker verbonden met de organisatie.

Uit deze applicaties is gebleken dat ons meetinstrument in bredere zin toepasbaar en funclioneel is, zonder dat de meetschaal daartoe drastische wijzigingen hoeft te ondergaan. Uitgaande van een uniforme basis kan het instrument in verschillende contexten (i.c. zowel idecle als tastbare goederen, alsmede diensten) toegepast worden. Dit komt de exteme validiteit, generaliseerbaarheid. en stabiliteit van onze eigen bevindingen ten goede.

Verder wordt aanbevolen het meetinstrument ook longitudinaal bij eenzelfde klantenbestand toe te passen zodat het instrument als een echte monitor gaat fungeren. In dat geval is het interessant onderzoek te doen naar de relatiesterkte en de loyaliteit van klanten voordat zij deelnemen aan een relatiemarketingprogramma in het algemeen of aan een klantenclub in het bijzonder, en hoe zich deze, vergeleken met niet-deelnemers uit dezelfde doelgroep, in de loop van de tijd (al of niet) wijzigen. Met andere woorden: de klassieke meting van veranderingen in de loop van de tijd in wergelijking met een 0-meting.

Daarnaast wordt aanbevolen te onderzoeken of de meetschaal ook in andersoortige interne en externe relaties bruikbaar is ${ }^{7}$, zonder dat de uitgangspunten van commitment als concept verlaten worden. Werd de OCQ oorspronkelijk toegepast op interne werkgever-werknemer relaties ('internal partnership"), de RCQ werd getoetst in klant-organisatie relaties ("buyer partnership'). De mogelijkheden om een overeenkomstige meetschaal toe te passen voor het meten van de sterkte van 'supplier partnerships' en 'lateral partnerships' dient nog nader onderzacht te worden'. Met name de eerder vermelde conclusies van Denize en Young (1996), die commitment hebben gemeten in de professionele dienstverlening ('supplier partnership'), dat commitment primair een attitude construct is en dat relatiesterkte het best gemeten kan worden door zakelijke afnemers te vragen naar hun gevoelens ten aanzien van hun relatie met de aanbieder, bieden in dat opzicht perspectief. Resultaten van recent onderzoek door Venetis

\footnotetext{
${ }^{7}$ Hierbij zij nogmaals venwezen naar fighur 2.1 , waarin de tien relatievormen zijn weergegeven die door Morgan en Hunt (1994) worden onderscheiden.

"Tot "supplier partnerships" worden gerekend (Morgan en Hunt, 1994):

- relaties tussen fabrikanten en hun leveranciers van goederen en onderdelen;

" relaties tussen een bedrijf en haar dienstverlenende organisaties (zoals marktonderzoekbureaus. banken).

'Lateral parmerships' kunnen zajn (Morgan en Hunt, 1994):

- strategische allianties tussen bedrijven en hun concurrenten;

- allianties tussen een bedrijt en mon profit organisaties;

- partherships voor gezamenlijke onderzoeks- en ontwikkelingsprojecten.
} 
(1997), die commiment eveneens heeft gemeten in de professionele dienstwerlening (i.c. tussen bedrijwen en hun reclamebureau), ondersteunen de conclusies an Denize en Young (1996).

In de relatiemarketingliteraturur wordt onderkend dat ook de organisatie (en daamee haar werknemers) positief moet(en) staan ten opzichte wan het opbouwen en onderhouden van relaties met afnemers. Ons onderzoek heeft met name plaatsgevonden vanuit het perspectief van de consument. Met andere woorden: gelet is met name op hoe de consument de relatie met zijn leverancier percipieert. Een relatie is echter weezijdig. Wil cen relatie bestaan dan dienen beide partijen het bestaan ervan te erkennen (Bames, 1995). Dit erkennen vanuit het oogpunt. wan de aanbieder is niet expliciet getoetst in ons onderzock. Het streven door de aanbieder naar het opbouwen, continueren en versterken van relaties met afnemers en daarmee het erkennen wan het belang van deze relaties door de aanbieder is als uitgangspunt genomen. Dit lijkt gerechtvaardigd gezien het feit dat beide bij het empirisch onderzoek betrokken aanbieders klantenclubs in het leven hebben geroepen en daarin investeren teneinde het belang dat $z i j$ hechten aan een sterke relatie met hun afnemers te onderstrepen.

In situaties waarin dit strewen niet expliciet tot uitdrukking gebracht wordt of sterk in twijfel getrokken moet worden, verdient het echter aanbeveling ook de perceptie van de aanbieder ten aanzien van relaties met afnemers te onderzoeken. Het heeft weing zin onderzoek naar relaties te doen en de mogelijkheden van relatiemanagement uiteen te zetten, indien een aanbieder de contacten met afnemers niet percipieert als een mogelijkheid on duurzame relaties op te bouwen. "A relationship does not exist merely because one partmer in an interaction perceives that one exists" (Barnes, 1995, p. 1394).

\subsubsection{SUGGESTIES TEN AANZIEN VAN HET RLM-MODEL}

Verder onderzoek kan zich ook richten op motieven voor consumenten om 'relationeel marktgedrag' te vertonen en hun beschikbare keuzewrijheid te beperken (Sheth en Parvatiyar, 1995). Er zou een antwoord gezocht kumnen worden op vragen als: Welke motieven heef de consument om een relatie met een organisatie aan te gaan? Waarom is hij bereid (een deel wan) zijn keuzevrijheid op te geven voor een expliciete relatie met een geselecteerde aanbieder? En watrom is hij bereid deze relatie te continueren, gelet op het gegeven dat de reden waarom een relatie wordt voortgezet, de aard van de relatie bepaalt (Denize en Young, 1996)? In hoofdstuk 6 werd gesuggerereerd dat de relatie met Gall \& Gall zowel enotioneel als rationeel van aurd is en dat de relatie met Gulpener voomamelyjk emotioneel van aard is. Het onderscheid in emotioneel en rationeel sluit aan bij het onderscheid in calculatief en affectief commitment (Allen en Meyer, 1990; Gundlach et al., 1995; Geyskens en Steenkamp, 1995; Geyskens et all, 1996; de Ruyter et al., 1997; Venetis, 1997).

Calculatief commitment duidt op een rationele afweging van plus- en mimpunten (baten en kosten). Op basis van bijvoorbeeld significante gepercipieerde overstapkosten, verbonden aan het verbreken van de relatie, kan de afnemer in meerdere of mindere mate de noodzaak ervaren de relatie met de aanbieder voort te zelten.

Affectief commitment verwijst naar een affectieve band tussen afnemer en aanbieder. Op basis van deze band bestaat bij de afnemer de wens de relatie met de aanbieder voort te zetten.

Beide zijn attituden ten aanzien van de relatie. Meer specifiek reflecteren deze attituden de huidige motivatie of reden de relatie voort te zetten (Dwyer et al., 1987; Venetis, 1997). Zij geven aan of sprake is wan calculatieve danwel affectieve beweegredenen voor de huidige mate van binding. Vergeleken met deze vormen van commitment is onze RCQ een meer generieke maatstaf voor de mate wan binding: de mate waarin iemand zich betrokken voelt bij en 
identifcert met een organisatie, zonder daabij te leten op de onderliggende motivatie of beweegreden.

Door een nader onderscheid te maken in de ard van het commitment kan ons RLM-model met een derde dimensie verrijkt worden (zie figuur 7.3). Het RLM-model geeft dan niet alleen het koopgedrag en de sterkte van de relatie zoals gepercipieerd door de klant weer, maar ook de aard van de relatie (en dearmee de reden voor 'relationeel marktgedrag").

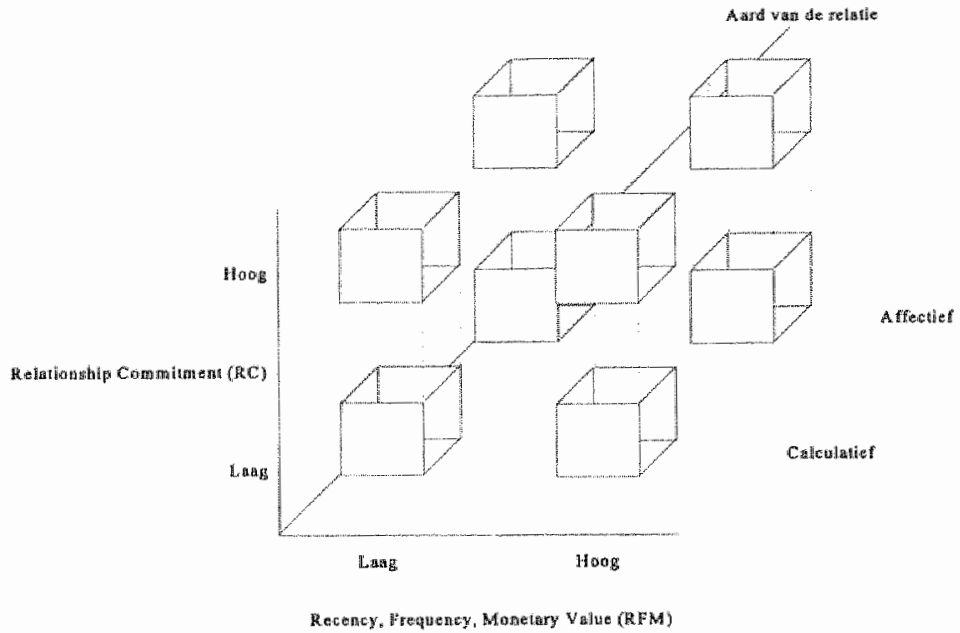

Figuur 7.3 Het RLM-model aangevuld met de dimensie 'aard van de relatie' waarin een nader onderscheid gemaakt wordt in affectief en calculatief commitment

Bron: de Wulfen Vergult (1997)

De aard van commitment (affectief of calculatief) geeft een verklaring voor de aangetroffen mate van binding en het "relationeel marktgedrag". Verder onderzoek zou zich dan kunnen richten op een nadere verklaring woor de mate van binding zoals aangetroffen bij de vrienden,

\footnotetext{
"Naast affectief en calcultatief commitment wordt ook nog wel een derde vorm van commutment onderscheiden, namelijk "normatief commitment" (Meyer en Allen, 1987; Allen en Meyer, 1990). Normatief commiment speelt naast calculatief en affectief commitment een (eigen) rol ais beweegreden om een bepalilde relatie te continueren. Normatief commitment heeft namelijk betrekking op de mate waarin de afnemer van mening is dat hij in zijn koopgedrag aan bepaalde sociale en institutionele normen tegemoet moet komen. Een relatie tussen afnemer A en leverancier B kan dus om normatieve redenen worden gecontinueerd, ondanks dat A tevens een affectieve relatie met leverancier C onderhoudt maar dat aldaar niet in het koopgedrag tot uiting laat komen. De relatie met B kan dan als normatief gekarakteriseerd worden.
} 
functionalisten, kennissen en sympathisanten. Zo is het denkbaar dall de relatiesterkte zoals gepercipieend door functionalisten met name calculatief van aard is. Calculatief commitment is een tamelijk negatieve beweegreden om de relatie te continueren (Geyskens et al., 1996; de Ruyter et al, 1997) en beinvloedt vanuit die optiek de relatiesterkte ook negatief. Bij vrienden daarentegen is het voorstelbaar dat beide vormen van commitment (calculatief an affectiol) aanwezig zijn.

In deze studie zijn relaties met klanten beschreven en geanalyseerd op basis van een onderzoek op éen bepaald moment in de tijd. Relaties zujn echter dynamisch. Dit impliceent dat klantenmigratie analyse (Sampathkumaran, 1994) het best als een continu, dynamisch proces kan worden gezien en toegepast. Een proces dat marketeers toestaat de effecten van relatiemanagementactiviteiten te monitoren. Aanbevolen wordt dus het RLM-model in een longitudinale onderzoeksopzet toe te passen en te testen.

Aansluitend op de opmerking ten aanzien van de generaliseerbeerheid wan het instrument om relatiesterkte te meten, wordt aanbevolen ook het RLM-model in meerdere industrietakken en ten aanzien van andersoortige interne en exteme partnerships toe te passen: "... companies have a number of markets to whom they need to direct marketing activity and formulate marketing plans. ... In addition to formulating marketing activity directed at existing and potential customers, a company should also consider supplier markets, employee markets, refertal markets, "influencer" and internal markets" (Christopher et al., 1991, p. 20).

Relatiemarketing heeft niet alleen gevolgen voor de klanten en hun relaties met de organisatie. Buttle (1996, p. 12) zegt hierover:

"..., new organizational struchures and reward schemes may be required. The traditional marketing and sales function is organized around products or geographic markes. Under the influence of RM, organization around customers becomes more sensible. Customer, or account, managers are better placed to build long-term relationships with clients, more deeply understanding their expectations and constructing financial, social and structural. links to the firm. .. Companies will also need to reconsider how they reward employees. At present, sales and marketing management is widely rewarded with a mix of basic salary and performance-related bonus or commission. Common performance criteria include sales volume and customer acquisition. Under the RM regime, customer managers are more likely to be rewarded by customer profitabilily, account penetration and customer retention."

Naast andere organisatiestructuren en beloningssystemen kan relatienarketing ook aanleiding geven tot gewijzigde methoden wan 'cost accounting". Methoden als 'Activity Based Costing (ABC)' en 'Customer Based Accounting (CBA)' zijn er op gebaseerd kosten en opbrengsten toe te rekenen aan de klant(activiteit) die ze veroorzakkt, en niet anan het produkt dat word geproduceerd (kosten) en verkocht (opbrengsten), zoals bij de 'direct costing' methode hei geval is (Burgers, 1997). Methoden als ABC en CBA stellen het management beter in staat beslissingen te nemen ten aanzien van welke klanten, die niet meer rendabol zjjn, afscheid genomen gaat worden. Het management kan aldus een weloverwogen keuze maken in welke klanten wel en in welke klanten niet meer zal worden geinvestecrd (oogsten/desinvesteren).

Organisatiestructuur, beloningssystemen en cost accounting methoden zijn daarbij ontegenzeggelijk met elkaar verbonden. Gewijzigde methoden van cost accounting als 'ABC" 
en 'CBA' kunen de noodzakelijke informatie apleveren om het (marketing- en verkooppersonel te belonen op basis van criteria als de winsigevendheid van de klant, het klantaandes en het behouden van de klant voor de organisatie. Het verdient aanbeveling de interne organisatiestructut daarop af te stemmen en (marketing- en verkoop) functies niel te organiseren naar produkten marar naar klanten (account management). Daarbij is het de vraag of een dergelige organisatie nog wel een specifieke marketingafdeling kent. Zo stelt Gummesson (1987a; 1987b) dat niel alleen een aantal (full time) professionele marketeers, maar iedereen in de organisatie (deeltijds) marketeer is en dat klantrelaties door iedere werknemer beinvloed worden. Er is echter nog onvoldoende onderzoek gedaan naar en inzicht verkregen in de gevolgen wan het implementeren van een relatiemarketingbenadering voor de interne organisatie en haar belonings- en accountingsysteem.

Behalve dat relatiemanagement aanleiding kan geven tot gewijzigde methoden van "cost accounting" kan ook een zekere invloed op de warde van de ondememing niet ontzegd worden. Eerder werd reeds opgemerkt dat betaalde 'goodwill" bij ovemame op de gepubliceerde balans geactiveerd mag worden. 'Goodwill' is een vergoeding die bij het kopen van een zak aan de eigenaar moet worden betald voor het overnemen van de klanten(relaties). Het is het verschil tussen de aankoopprijs van het beoogde bedrijf en de watrde van zijn netto-activa (Kapferer, 1996). Deze vergoeding komt in de praktijk in het algeneen door onderthandelen tot stand (Blommaert en Blommaert, 1986). Indien de ondememer, die zijn zaak wil verkopen, kan aantonen dat zijn klantenbestand voornamelijk uit 'vrienden' bestat, versterkt dit zijn onderhandelingsposithe. Ongekeerd heef de koper er baat bij indien hij kan aantonen dat het klantenbestand dat hij overneemt voomamelijk uit "Kennissen" bestaat. Met andere woorden: de verdeling van de klanten over de vier segmenten van het RLM-model zou meegenomen kunnen worden bij het bepalen van de 'goodwill' en daarmee de waarde van een bedrij. Naar de invloed van de specifieke samenstelling van het klantenbestand, op basis van het RLM-model, op de waarde van de ondememing in het algemeen en de 'goodwill' in het bijzonder is voorzover ons bekend geen onderzoek gedaan.

Bij een organisatie die het principe van de merkenparapiu toepast (zoals Unilever en Procter \& Gamble) kan niet verondersteld worden dat consumenten een sterke binding ervaren met de organisatic. De binding met de organisatie dient dan te worden afgeleid uit de binding met de afzonderlike merken die onder de merkenparaplu van die organisatie vallen (Hoekstra, 1998). Goodwill (welwillendheid) wordt dan bepaald doon de warde van de afzonderlijke merken van de betreffende onderneming. De waarde van een merk wordt (naast zaken als: octrooien, de exclusiviteit van know how van de ondememing en de kwaliteit van de betrekkingen met de netwerken) bepanld door de antrekkingskracht van het merk op de doelgroep die ermee in wisselworking stat. Met andere woorden: bij de waardebepaling van een merk speelt de mate van identificatie, de binding die de afnemer met het merk percipieent een rol (Kapferer, 1996). Bloemer (1994) gaf al aan dat, indien een organisatie de waarde van het merk op de balans wenst te activeren (als immaterieel activum), daarbij nadrukkelijk rekening moet worden gehouden met de soort mektrouw van de consument; "In termen van merkwaardering betekent dit dat een merk met een grote waarlijk trowwe aanhang cen grotere walde vertegenwoordigi dan een merk met een beperkte warlijk trowwe aanhang of hooguit herhalingsaankopers" ( $p$. 643). Het RLM-model, i.c. toegepast op de binding met een afzonderlik merk in plats van met een organisatie, biedt de mogelijkheid inzicht te verkrijgen in de verhouding tussen waarlijk trowwe en beperkt waarlijk trouwe aanhangers of harhalingsaankopers. 
Ook wordt gesteld dat klanten in de toekomst er steeds meer toe zullen overgan hun relaties met aanbieders zelf te managen, gebruik makend van nieuwe technologieurn (Stone et al., 1996). De klant zal zelf de mate van binding gaan/willen bepalen en wordt minder gevoelig voor de benaderingswijze van de aanbieder. Er zal dan minder sprake van zijn dat de klant uit een aantal benaderingswijzen kiest en aangeeft op welke wijze hij door welke aubieder benaderd wenst te worden om vervolgens af te wachten of de aumbieder aan zijn wensen tegemoet komt. De klant zall het initiatief binnen de relatie meer in eigen handen gaan nemen. Aanbieders dienen zich daarop voor te bereiden door op elk door de klant gewenst moment ower die faciliteiten te beschikken waar de klant gebruik van wil maken. Internet, 24-uur telefonische bereikbaarheid en fax zijn voorbeelden wan dergelijke facilliteiten. Aambieders zullen voorbereid moeten zijn zelf alert op de klant te reageren in plaats van de klant op hun benaderingswijze te laten reageren. Ook dat heeft gevolgen voor zowel de relatiesterkte als de interne organisatie, maar onduidelijk is in welke vorm en in welke mate.

In ons onderzoek is het RIM-model invulling gegeven op basis van een steekproef. Een organisatie wil in het algemeen echter het liefst har hele klantenbestand in het RLM-model onderbrengen, zonder dat daar in éen keer grote investeringen voor onderzoek voor nodig zijn. Wat zijn de mogelijkheden daartoe? Hier volgen enkelle suggesties die zich lenen voor nader onderzoek.

Ten eerste kan gebruik gemaakt worden van 'customer profiling": "This involves constructing a profile of existing profitable accounts and searching the prospect or light-user database for customers of similar profile." (Buttle, 1996, p. 7). Binnen de segmenten die op basis van koopgedrag en relatiesterkte onderscheiden zijn (vrienden, kemnissen, functionalisten en sympathisanten), kan bijvoorbeeld naar onderscheidende sociaal-demografische en/of geodemografische achtergrondkenmerken gezocht worden. Op basis daarvan than vervolgens het hele bestand geclassificeerd worden en kan voor elke klant afzonderlijk de meest aangewezen strategie bepaald worden (1:1 benadering).

Een tweede mogelijkheid is dat het databestand fasegewijs onderzocht en aangevuld wordt met de noodzakelijke gegevens. De meetschaal is geschikt oni in de reguliere contacten met klanten toegepast te worden. Ook dit resulteert in de mogelijkheid van een $1: 1$ benadering.

Opgemerkt wordt dat het niet altijd noodzakelijk is het volledige klantenbestand ie onderzoeken op relatiesterkte om strategische beslissingen te kunnen onderbouwen of to evalueren. Bij de vraag of een relatiemarketingprogramma op de markt gebracht kan worden, kan een steekproef voldoende informatie opleveren om deze beslissing afgewogen te nemen.

Een andere mogelijkheid om strategische beslissingen te kunnen onderbouwen of te evalueren, wrarbij niet het hele bestand wordt onderzocht, is het organiseren van een (consumenten)panel dat aan een longitudinaal onderzoek onderworpen wordt. Leden van dit panel kunnen overeenkomstig het RLM-model geclassificeerd worden. Vervolgens krijgen ze die benadering die het meest voor de hand ligt. Door het RLM-model als monitor in een dergelijke quasi experimentele onderzoeksopzet toe te passen, kumen de ontwikkelingen in de relaties gemeten en gevolgd worden (De Pelsmacker en Van Kenlrove, 1994; Churchill, 1995; Malhotra, 1996). Op die manier kan tot een meer gefundeerde kosten-baten analyse gekomen worden teneinde de beslissing, om het hele bestand te (laten) onderzoeken, meer verantwoord te kunnen nemen. 


\subsubsection{SUGGESTIES TEN AAMZIEN VAN HET MODEL TER VERKLARING VAN RELATIE- STERKTE.}

Uit ons onderzoek bleek dat de respondenten van beide studies voomamelijk uit mannen bestaan, in voomamelijk de leeftijdsklasse $40-49$ jaar met een hogere beroepsopleiding als relatief meest genoemde hoogst genoten opleiding. Deze samenstelling van de respondenten kan een vertekening ('bias') in de resultaten betekenen. Niet zozeer voor wat betreft de variabelen die als verklarende variabelen voor relatiesterkte in ons model zijn opgenomen: die variabelen zijn namelijk gebaseerd op een uitgebreide studie van literatuur op de gebieden van dienstenmarketing, business-to-business marketing en relatiemarketing en kwamen daar herhaaldelijk als meest relevante variabelen naar voren. Maar wel voor wat betreft de mate waarin deze variabelen in staat zijn relatiesterkte te verklaren, met andere woorden het relatieve belang. Mathieu en Zajac (1990) toonden op basis van een meta-analyse aan dat in werkgever. werknemer relaties vrowwen zich enigszins sterker verbonden voelen met de werkgever dan mannen en dal deze verbondenheid eerder affectief, dan calculatief van aard is. Uit recent motivatie-onderzoek van het Muys Management Center uit Breda bleek dat in een werkgeverwerknemer relatie mannen meer waarde hechten aan salaris en vrouwen aan erkenning, aanzien en goede persoonlijke relaties (De Limburger, 5 febnari 1998). Het is dus voorstelbaar dat mannen, binnen een commerciele relatie, meer belang hechten aan "hard benefits" (bijvoorbecld accessoires bij aankoop wan een auto) dan vrouwen, die mogelijk meer belang hechten aan de "soft benefits" (zoals serviceverlening door de dealer). Er zou dan ook nader onderzoek gedaan moeten worden bij relatiemarketingprogramma's waarbij sprake is van een meer evenwichtige verhouding tussen mannen en vrouwen en bij programma's waarbij het merendeel van de respondenten uit vrouwen bestaat. Een meta-analyse kan dan meer inzicht verschaffen in mogelijke verschillen tussen mannen en vrouwen voor wat betreft relatiesterkte en aard van de relatie.

Verder onderzoek naar factoren die relatiesterkte beïnvloeden verdient aanbeveling, met name wat betreft de bepalende variabelen die in het model kunnen worden opgenomen. De verklaarde variantie van de onderzochte modellen duidt er op dat meer variabelen invloed uitoefenen op relatiesterkte. De vraag is dus: welke variabelen dragen bij aan een verdere verklaring van relatiesterkte? Variabelen als produktbetrokkenheid, keuzebetrokkenheid en ervaring, zoals gesuggereend door De Boer en Waarts (1997), kunnen een eerste aanzet zijn de sterkte van iemands betrokkenheid bij en identificatie met een organisatie nader te verklaren. Zo zullen produkten die door een persoon als "low involvement" goederen gepercipieerd worden niet of nauwelijks leiden tot een sterke relatie met de aanbieder van deze goederen, terwijl als "high involvement" gepercipieerde goederen wel tot een sterke relatie met de aanbieder er van aanleiding kunnen geven (Mittal en Lee, 1988). Daarnaast zal keuzebetrokkenheid positief van invloed zijn op de binding met een leverancier, naarmate hel belang van een goede keuze groter is. Met andere woorden: naarmate het maken van de juiste keuze van en aanbieder voor de afnemer belangrijker is, zal de binding met de uiteindelijk gekozen aambieder sterker zijn (Beatty et al, 1988; Mittal en Lee, 1989). Tot slot verwachten De Boer en Waarts (1997) op basis van onderzoek van Anderson en Weitz (1989) dat naast de soort ervaring bij de klant (tevreden of ontevreden) ook de hoeveetheid ervaring positief van invloed is op de mate van binding. Ervaring heeft dan bijwoorbeeld betrekking op het aantal aankopen dat een afnemer tot dan toe heef verricht bij zijn gebruikelijke aanbieder (De Boer en Waarts, 1997), hetgeen in het algemeen samenhangt met de duur van de relatie tussen 
aanbieder en afremer (Anderson en Weitz, 1989). Aantal aankopen en duur van de relatie zijn in ons onderzoek beschouwd als koopgedragvariabelen. Variabelen betreffende het koopgedrag bleken in het onderzoek wan Denize en Young (1996) echter geen directe significante bijdrage te leveren aan de werklaring van relatiesterkte. Denize en Young (1996) stelden in hun onderzoek namelijk vast dat de gedragscomponent van het door hen gebruikte commitment construct met geen van de validatiemaatstaven een sterk verband toonde: noch met een directe maatstaf woor de mate van gepercipieerde commitment, noch met items die gericht waren op de kwaliteit van de relatie en de wens de relatie te beëindigen. De attitude component van hun commitment construct daarentegen leverde wel een significant verband op net de validatiemaatstaven: respondenten met een hoge mate van commitment hadden geen behoefte de relatie te beëindigen en gaven aan zich sterk verbonden te voelen met de partner. Mogelijk is het zo dat gedragsaspecten, die met commitment in verband gebracht worden, niet direct maar indirect verband houden met relationship commitment, en dat tussen commitment en deze gedragsvariabelen andere variabelen of factoren interveniëren ${ }^{10}$. Indien koopgedrag als antecedent van relatiesterkte beschouwd word, kan gedacht worden aan de eerdergenoemde belevingsvariabelen vertrouwen, attractiviteit en overstapkosten. Wordt koopgedrag gezien a!s resultante van relatiesterkte, dan is er mogelijk een aantal ongevingsfactoren dat het feitelijke koopgedrag mede bepaalt. Daarmee zou het door ons in hoofdstuk 4 gepresenteerde en in hoofdstuk 6 getoetste regressiemodel uitgebreid kunnen worden tot hel in figutur 7.4 weergegeven algemene model. Daarin wordt de loyaliteit van een individuele afnemer niet. alleen bepaald door de sterkte van de relatie tussen aanbieder en afnemer, maar ook door sociale en institutionele invloeden (Sheth en Parvatiyar, 1995). Tevens bepaalt loyaliteit op zijn beurt weer (indirect) de mate van binding.

De rol van ervaring, produkt- en keuzebetrokkenheid als (indirect) antecedent of gevolg van relatiesterkte zou nader onderzocht kunnen worden. In figuur 7.4 zijn deze variabelen, alsmede de verschillende vormen van relationship commitment, opgenomen: en algeneen en uitgebreid onderzoeksmodel van de totstandkoming van een relatie.

\footnotetext{
10 Deze bevinding correspondeert met resultaten gepresenteerd in de literatuur op hel gebied van organisatie-psychologie en organisatiegedrag. Op basis van een meta-analyse concluderen Matheu en Zajac (1990) dat het niet voor de hand ligt dat er sprake is van cen rechtstreekse relatic iussen organizational commitment en feitelijk gedrag, maar dat andere factoren (zoals beloningsbeleid of de beschikbaarheid van alternatieve werkgevers) cen medièrende (bemiddelende) of modererende (matigende) rol daarin spelen.
} 


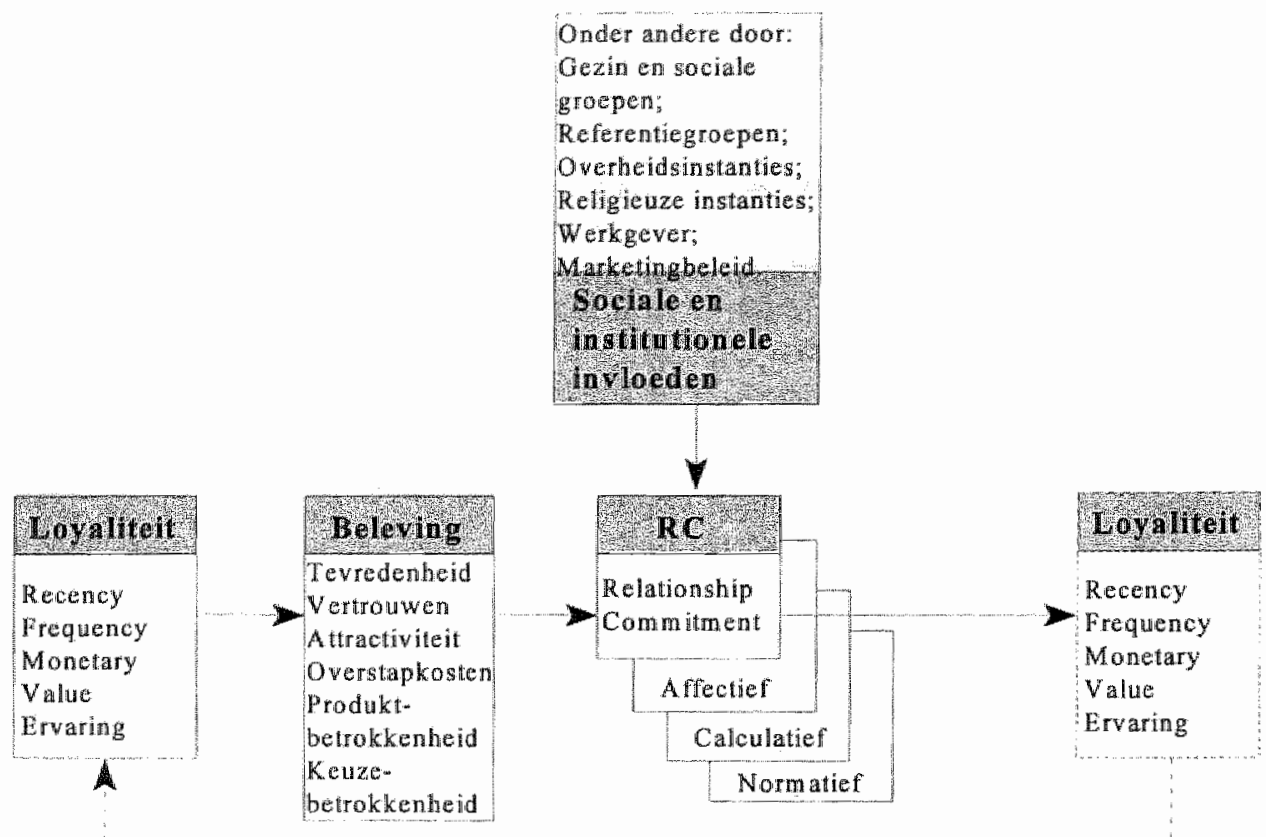

Figuur 7.4 Een algemeen en uitgebreid onderzoeksmodel van de torstandkoming van een relatie 


\section{BIJLAGE 1:}

\section{VRAGENLIJST TEN BEHOEVE VAN DE GULPENER STUDIE}

V1. Bent $U$ lid van het Gulpener biergilde?

ja, en wel: uit persoonlijke interesse (ENQ: Verder met V2)

ja, en well: Uit beropsmatige interesse (ENQ: Beaindig gesprek)

nee, maar ik ben wel lid geweest, en wel:

wit persoonlijke interesse (ENQ: Verder met $\mathrm{V} 3$ )

nee, maar ik ben wel lid geweest, en wel:

nee (ENQ: Verder met $\mathrm{V}_{3}$ )

uit beroepsmatige interesse (ENQ: Beeindig gesprek)

(NIET NOEMEN) weet nietwil/kan niet zeggen

V2. Sinds wanneer bent $U$ lid? (Kijk eventueel op uw clubpas.)

1991

1992

1993

1994

1995

(NIET NOEMEN) weet miet/wil/kan niet zeggen

V3. Koopt U wel eens Gulpener bier (Bijvoorbeeld un: supermarkt, winkel, café of restaurant)?

ja

nee (ENQ: verder met tekst vóór V16)

(NIET NOEMEN) weet niev/wil/kan niet zeggen

V4. Hoe lang koopt U al Gulpener bier, in jaren uitgedrukt?

(ENQ: NOTEER AANTAL JAREN; korter dan 1 jart is code 0 ; weet net is esc.d)

V5. Wanneer heeft $U$ voor het laatst Gulpener bier gekocht?

(ENQ: NOEM ANTWOORDMOGELIJKHEDEN)

minder dan 1 week geleden

1 tot 2 weken geleden

2 tot 3 weken geleden

3 tot 4 weken geleden

langer dan 4 weken geleden

(NIET NOEMEN) weet niet/wilkan niet zeggen

V6. Hoe wak koopt U Gulpener bier?

(ENQ: NOEM ANTWOORDMOGELIKHEDEN)

iedlere week

iedere 2 weken

iedere maand

ledere 2 maanden

minder vaak dan iedere 2 maanden

(NIET NOEMEN) weet niet/wil/kan niet zeggen 
ฟ7. Hot regelmatig of onregelmatig $20 j n$ Uw ankopen wan Gulpener bier over het jaar verdeeld?

(ENQ: NOEM ANTWOORDMOGELIJKHEDEN)

zear regelmatig

regelmatig

noch regelmatig, noch onregelmatig

onregelmatig

zeer onregelmatig.

(WIET NOEMEN) weet niet/wilkan niet zeggen

V8. Hoevel besteed U gemiddeld per maand aan Gulpener bier (in guldens)?

(ENQ: NOTEER BEDRAG IN GULDENS; WEET NIET IS ESC.D)

Vo. Hoevel procent van Uw bieraankopen besteedt $U$, gemiddeld genomen, aan Gulpener bier?

(ENQ: NOTEER PROCENTEN; WEET NIET IS ESC.D)

(ENQ: indien $100 \%$, ga verder met V11)

V10. Hoevel andere merken bier koopt $U$ nast Gulpener?

(ENQ: NOTEER AANTAL MERKEN; WEET NIET IS ESC.D)

VI1. Indlen U de prijs van Gulpener bier vergelijkt met de kwaliteit ervan, hoe tevreden of ontevreden bent $U$ dan over deze prijs-kwaliteit verhouding?

(ENQ: NOEM ANTWOORDMOGELIKKHEDEN)

zeer tevreden

levreden

noch tevreden, noch ontevreden

ontevreden

zeer ontevreden

(NIET NOEMEN) weet nietwil/kan niet zeggen

V12. Hoe tevreden of ontevreden bent $U$ over de prijs-kwaliteit verhouding van Gulpener bier als $U$ deze vergelijkt met de prijs-kwaliteit verlhouding van andere merken bier?

(ENQ: NOEM ANTWOORDMOGELIJKHEDEM)

zeer tevreden

tevreden

noch tovreden, noch onteveden

onterveden

zeer ontevreden

(NIET NOEMEN) weet niet/wilkan niet zeggen 
It lees $U$ nu een stelling voor. Wilt $U$ mij dan zeggen in hoeverre $U$ het daarmee aens of oneens bent.

V13. Iedere keer nadat U Gulpener bier gekocht heeft, denkt U nog eens over Uw keuze voor Gulpener na.

(ENQ: NOEM ANTWOORDMOGELIJKHEDEN)

volledig eens

eens

noch eens, noch oneens

oneens

volledig oneens

(NIET NOEMEN) weet niet/wil/kan niet zeggen

W14. Koopt U meerdere soorten Gulpener bier?

ja

nee (ENQ: ga verder met tekst vóór V16)

(NIET NOEMEN) weet niet/wil/kan niet zeggen

V15. Welke soorten Gulpener bier koopt U wel eens?

(ENQ: MEERDERE ANTWOORDEN MOGELUK)

Gulpener pils

Gulpener Dort

Gulpener Chateau Neubourgh

Gulpener Oud Bruin

Gulpener Bockbier

Gulpener Sjoes

Gulpener Meibock

Gulpener Korenwolf

andere soorten, namelijk (ENQ: TIK IN)

(NIET NOEMEN) weet niet/wil/kan niet zeggen

Tot nu toe gingen de vragen over het kopen van Gulpener bier. U kunt echter ook op een andere manier in aanraking komen met de Gulpener Bierbrouwerij of haar produkten. Denkt U daarbij aan: het spreken met werknemers van Gulpener; het lezen over Gullpener, het zien of horen van reclame-nitingen over Gulpener; het drinken van of praten over Gulpener bij familie, vrienden of kennissen; ed. We noemen deze manieren van in aanraking komen met de Gulpener Bierbrouwerij of haar produkten: "in confact komen wet Gulpener". Hierower gaan de volgende vragen.

V16. Hoe komt $U$ in contact met Gulpener?

(ENQ: NOEM OP; MEERDERF ANTWOORDEN MOGELIJK)

schriftelijk (o.a.: brieven, tijdschrift, advertenties in kranten en thjschriften)

telefonisch

mondeling (o.a.: met personeel van Gulpener of door gesprekken met anderen over Gulpener) 3

via radio (reclamespot)

niet, nooit

(NIET NOEMEN) weet niet/wil/kan niet zeggen

(ENQ: indien V3 is "nee' en V16 is "niet, nooit", dan gesprek voortzetten bij V65) 
VI7. Hoeveel Jarengelleden bent U woor het eerst in contact gekomen met Gulpener? (ENQ: NOTEER AANTAL JAREN; WEET NIET IS ESC.D)

V18. Wanneer bent $U$ voor het laatst in contact gekomen met Gulpener?

(ENQ: NOEM ANTWOORDMOGELIJKHEDEN)

minder dan 1 week geleden

1 tot 2 welken geleden

2 tot 3 weken geleden

3 tot 4 weken geleden

langer dan 4 weken geleden

(NIET NOEMEN) weet niet/wil/kan niet zeggen

V19. Hoe waak komt $U$ in contact met Gulpener?

(ENQ: NOEM ANTWOORDMOGELIJKHEDEN)

iedere week

iedere 2 weken

iedere mand

iedere 2 maanden

minder wak dan iedere 2 maanden

(NIET NOEMEN) weet niet//wil/kan niet zeggen

V20. Hoe regelmatig of on regelmatig komt $\mathrm{U}$, over een jaar genomen, in contact met Gulpener?

(ENQ: NOEM ANTWOORDMOGELIJKHEDEN)

zeer regelmatig

regelmatig

noch regelmatig, noch onregelmatig

onregelmatig

zeer onregelmatig

(NIET NOEMEN) weet niet/wil/kan niet zeggen

V21. Hoe tevreden of ontevreden bent $U$ over de contacten met Gulpener, ZONDER deze te vergelijken met de contacten met andere bierbrouwers

(ENQ: NOEM ANTWOORDMOGELJKKHEDEN)

zeer tevreden

tevreden

noch tevreden, noch ontevreden

ontevreden

zeer ontewteden

(NIET NOEMEN) weet nied/wil/kan niet zeggen

V22. Hoe tevreden of ontevreden bent $\mathrm{U}$ over de contacten met Gulpener, als $\mathrm{U}$ deze contacten WEll vergelijkt met de contacten met andere bierbrouwers?

(ENQ: NOEM ANTWOORDMOGELIJKHEDEN)

zeer tevreden:

tevireden

noch tevreden, noch ontewreden

ontevreden

zeer ontevreden

(NIET NOEMEN) weet niet/wilkan niet zeggen 
$\mathrm{Ik}$ lees $\mathrm{U}$ n een stelling voor. Wilt $\mathrm{U}$ mij dan zeggen in hoeverre $\mathrm{U}$ het daamee exs of areens bent.

V23. Iedere keer nadat $U$ in contact gekomen bent met Gulpener, denkt U daax nog cens over na.

(ENQ: NOEM ANTWOORDMOGELIJKHEDEN)

yolledig eens

eens

noch eens, noch oneens

oneens

volledig oneens

(NIET NOEMEN) weet niet/wil/kan niet zeggen

Ik lees $U$ nu een stelling voor. Wilt $U$ mij dan zeggen in hoeverre $U$ het daarmee cens of oneens bent.

V24. U neemt ook ZELF het initiatief om schriftellik, telefonisch of mondeling met Gulpener in contact te komen.

(ENQ: NOEM ANTWOORDMOGELIJKHEDEN)

volledig eens

eens

noch eens, noch oneens

oneens

volledig oneens

(NIET NOEMEN) weet niet/wil/kan niet zeggen

De volgende vragen hebben betrekking op zowel het kopen van Gulpener bier als op het op enigerlei wijze in contact komen met Gulpener. Dit zullen we kortweg de band met Gulpener noemen. De band met Gulpener kan op verschillende punten worden beoordeeld. Ik ga U nu een aantal punten noemen.

V25. Ervaart U de band met Gulpener als......?

(ENQ: NOEM ANTWOORDMOGELIJKHEDEN)

zeer diepgaand

diepgaand

noch opperwlakkig, noch diepgatand

oppervlakkig

zeer oppervlakkig

(NIET NOEMEN) weet niet/wil/kan niet zeggen

V26. Ervaart U de band met Gulpener als.....?

(ENQ: NOEM ANTWOORDMOGELIJKHEDEN)

zeer waardevol

waardevol

noch wardevol, noch wavideloos

waardeloos

zeer waardeloos

(NIET NOEMEN) weet niet/wil/kan niet zeggen 
V27. Ervaart U de band met Gulpewer als....?

(ENQ: NOEM ANTWOORDMOGELLKHEDEN)

zeer plezierig

plezierig

noch plezierig, noch onplezierig

onplezierig

zeer omplezierig

(NIET NOEMEN) weet nietiwil/kan niet zeggen

V28. Ervaart U de band met Gulpener als....

(ENQ: NOEM ANTWOORDMOGELIJKHEDEN)

zeer langdurig

langdurig

noch kortstondig, noch langdurig

kortstondig

zeer kortstondig

(NIE'T NOEMEN) weet niet/wil/kan niet zeggen

V29. Hoe gemakkelijk of moeilijk is het woor U om te stoppen met deze band?

(ENQ: NOEM ANTWOORDMOGELTJKFEDEN)

zeer moeilijk

moeilijk

noch gemakkelijk, noch moeilijk

gemakkelijk

zeer gemakkelijk

(NIET NOEMEN) weet niet/wil/kan niet zeggen

V30. Hoe gemakkelijk of moeilijk is het voor $U$ om een band met een ander merk of bierbrowwerij anu te gaan?

(ENQ: NOEM ANTWOORDMOGELIJKHEDEN)

zeer moeilijk

moeilijk

noch gemakkelijk, noch moeilijk

gemakkelijk

zeer gemakkelijk

(NIET NOEMEN) weet niet/wil/kan niet zeggen

V31. In welke mate accepteert $U$ fouten of vergissingen, door Gulpener gemankt, voordat $U$ besluit nam een ander merk bier over te stappen?"

(ENQ: NOEM ANTWOORDMOGELIJKHEDEN)

in zeer hoge mate

in hoge mate

noch in hoge, noch in geringe mate

in geringe mate

in het geheel niet

(NIET NOEMEN) weet niet/wil/kan niet zeggen 
$\mathbb{K}$ lees $\mathrm{U}$ nu een stelling voor. Wilt $\mathrm{U}$ mïj dan zeggen in hoeverre $U$ het daarmee eans of oneens bent.

V32. In geval van fouten of vergissingen, door Guipener gemaakt, gaat $\mathrm{U}$ over tot het indienen van een klacht bij Gulpener of haar verkooppunt.

(ENQ: NOEM ANTWOORDMOGELIJKHEDEN)

volledigeens

eens

noch eens, noch oneens

oneens

volledig oneens

(NIET NOEMEN) weet niet/wilkan miet zeggen

V33. Ik noem nu een aantal manieren waarop de band met Gulpener omsehreven kan worden.

Welke daarvan geeft $U$ w huidige band met Gulpener het beste weer?

(ENQ: NOEM OP EN HERHAAL VERVOLGENS DE ANTWOORDMOGELIJKHEDEN)

Gulpener onderneemt werder niets om met $U$ in contact te komen.

Gulpener stimuleert $\mathrm{U}$ on contact met haar op te nemen als U vragen of klachten heef. 2

Gulpener informeert enige tijd na de aankoop of U tevreden bent.

Gulpener neemt van tijd tot tijd contact met $U$ op en toont interesse in $U$.

Gulpener zoekt samen met U naar probleemoplossingen en produkiverbeteringen.

(NIET NOEMEN) weet niet/wil/kan niet zeggen

V34. Bent $\mathbf{U}$ van plan om in de toekomst Gulpener te (blijven) kopen?

Ja

Nee (ENQ: Ga verder met tekst vóór V36)

(NIET NOEMEN) weet niet/wil/kan niet zeggen

V35. Ik noem nu een aantal manieren waarop de band met Gulpener omschreven kan worden.

Welke daarvan geeft de door $\mathrm{U}$ gewenste band met Gulpener het beste weer?

(ENQ: NOEM ANTWOORDMOGELIJKHEDEN)

$U$ wil niet dat Gulpener iets onderneemt om met $U$ in contact te komen.

$U$ wil dat Gulpener $U$ stimuleert om contact met haar op te nemen als $U$ vragen of klachten

heeft.

U will dat Gulpener enige thid na de aankoop informeert of U tevreden bent.

$U$ wil dat Gulpener van tijd to thjd contact met $U$ opneent on interesse in $U$ toont.

U wil dat Gulpener samen met U naar proble emoplossingen en produkiverbeteringen zoekt.

(NIET NOEMEN) weet niet/wilkan niet zeggen

Ik lees $U$ nu enkele stellingen voor. Wilt $U$ mij dan steeds zeggen in hoeverre $U$ hewt. daarmee eens of oneens bent.

V36. Als U wan plan bent Gullpener bier te kopen, is het gemakkelijk om U wan gedachten te doen veranderen en feitelijk een ander merk bier te doen kopen.

(ENQ: NOEM ANTWOORDMOGELIJKHEDEN)

volledig eens

eens

noch eens, noch oneens

oneens

volledig oneens

(NIET NOEMEN) weet niet/wilkam niet zeggen 
V37. Wameer Gulpener bier niet verkrijgbaar is in de winkel, dan gaat $U$ naar een andere winkel om hef daar te kopen.

(ENQ: NOEM ANTWOORDMOGELIKHEDEN)

volledig eens

exins:

noch eens, noch oneens.

oncens

wolledig oneens

(WIET NOEMEN) weet niet/wil/kan nief zeggen

V38. Wanneer een ander merk bier dan Gulpener in de aanbleding is, koopt $\mathbf{U}$ dat eerder dan Gulpener.

(ENQ: NOEM ANTWOORDMOGELIJKHEDEN)

volledig eens

eens

noch eens, noch oneens

oncens

volledig oneens

(NIET NOEMEN) weet niet/wil/kan niet zeggen

V39. Neemt $U$ bij het kopen wan bier ook andere merken dan Gulpener in beschouwing? Zo ja, hoevel andere merken?

(ENQ: NOTEER AANTAL ANDERE MERKEN; WEET NIET IS ESC.D)

V40. Hoe trouw vindt U zichzelf ten opzichte wan Gulpener?

(ENQ: NOEM ANTWOORDMOGELIJKHEDEN)

zeer trouw

trouw

noch trouw, noch ontrouw

ontrouw

zeer ontrouw

(NIET NOEMEN) weet niet/wil/kan niet zeggen

V41, In walke mate voelt U zich op Uw gemak met Gulpener?

(ENQ: NOEM ANTWOORDMOGELIKKHEDEN)

in zeer hoge mate

in hoge mate

noch in hoge, noch in geringe mate

in geringe nate

in thet geheel nict

(NIET NOEMEN) weet nied/wil/kan niet zeggen

V42. In welke mate heeft U vertrouwen in Gulpener?

(ENQ: NOEM ANTWOORDMOGELIJKHEDEN)

in zeer hoge mate

in hoge mate

noch in hoge, noch in geringe mate 
IK lees $U$ nu enkele stellingen woor. Wilt $U$ mij dan telkens zeggen in hoeverre $U$ het daarmee eens of oneens bent.

V43. U drinkt Gulpener bier, omdat mensen die Gulpener bier drinken, gezien worden als bierdrinkers met een goede smaak.

(ENQ: NOEM ANTWOORDMOGELUKHEDEN)

volledig eens

eens

noch eens, noch oneens

oneens

volledig oneens.

(NIET NOEMEN) weet niet/wil/kan niet zeggen

V44. U drinkt Gulpener bier, ondat $U$ zich betrokken woelt bij de Gulpener brouwerij.

(ENQ: NOEM ANTWOORDMOGELIKKHEDEN)

volledig eens

eens

noch eens, noch oneens

oneens

volledig oneens

(NIET NOEMEN) weet niet/wil/kan niet zeggen

V45. U drinkt Gulpener bier, omdat bepaalde eigenschappen van Gulpener bier (zoals smaak en prijs) goed aansluiten op Uw wensen.

(ENQ: NOEM ANTWOORDMOGELIJKHEDEN)

volledig eens

cens

noch eens, noch oneens

oneens

volledig oneens

(NIET NOEMEN) weet niet/wil/kan niet zeggen

V46. Hoe tevreden of ontevreden bent $U$ in het algemeen over de Gulpener brouwerij en haar produkten?

(ENQ: NOEM ANTWOORDMOGELIJKHEDEN)

zeer tevreden

tevreden

noch tevreden, noch ontevreden

ontevreden

zeer ontevreden

(NIET NOEMEN) weet niet/wil/kan niet zeggen

V47. Wanneer $U$ het totaabeeld van Gulpener vergelijkt met Uw beeld van andere brouwerijen of biermerken, is Uw beeld van Gulpener dan positiever of negatiever dan dat van anderen? (ENQ: NOEM ANTWOORDMOGELIJKHEDEN)

veel positiever

positiever

noch positiever, noch negatiever

negatiever

veel negatiever

(NIET NOEMEN) weet nied/wil/kan niet zeggen 
V48. In welke mate werwach $U$ in de toekomst meer of minder Gulpener bier te gaan kopen? (ENQ: NOEM ANTWOORDMOGELIJKHEDEN)

veel meer

meer:

noch meer, noch minder

minder

veel minder

(NIET NOEMEN) weet nietwil/kan niet zeggen

Dan wolgen nu nog enkele stellingen. Deze hebben betrekking op de Gulpener browwerij en haar produkten in het algemeen. Wilt $U$ mij telkens zeggen in hoeverre $U$ het daarmee eens of oneens bent!

V49. U bent bereïd extra moeite te doen om bier van Gulpener te kunnen kopen.

(ENQ: NOEM ANTWOORDMOGELIJKHEDEN)

volledig cens

eens

noch eens, noch oneens

oneens

volledig oneens

(NIET NOEMEN) weet net/wil/kan niet zeggen

V50. U prijst Gulpener aan bij Uw vrienden als een organisatie die prima bier brouwt. (ENQ: NOEM ANTWOORDMOGELIJKHEDEN)

volledig eens

eens

noch eens, noch oneens

oneens

volledig oneens

(NIET NOEMEN) weet niet/wil/kan niet zeggen

V51. U voelt erg weinig loyaliteit naar Gulpener toe.

(ENQ: NOEM ANTWOORDMOGELLJKHEDEN)

volledigeens

eens

noch eens, noch oneens

oneens

volledig oneens

(NIET NOEMEN) weet niet/wil/kan niet zeggen

V52. U zou een prijsverhoging van $10 \%$ accepteren, om bier van Gulpener te kunnem blijven drinken.

(ENQ: NOEM ANTWOORDMOGELIJKHEDEN)

volledig eens

aens

noch eens, noch oneens

oneens 
Uit tabel $6.17 \mathrm{kan}$ worden afgeleid dat leden/kaarthouders ten aanzien van elk van de tien items, waanit de $\mathrm{RCQ}$ is opgebouwd, significant positiever scoren dan ex-leden/exkaarthouders. In die zin percipièren leden een sterkere relatie dan ex-leden. Dat houdt dus in dat leden, in vergelijking tot ex-leden, in sterkere mate van mening zijn dat zij:

1. bereid zijn extra moeite te doen om bij Gall \& Gall te kunnen kopen;

2. Gall \& Gall aanbevelen bij hun vrienden;

3. zichzelf trouw vinden aan Gall \& Gall;

4. hun waarden en normen in overeenstemming zien met die van Gall \& Gall;

5. met meer trots anderen vertellen dat zij bij Gall \& Gall kopen;

6. bij Gall \& Gall blijwen kopen, ook als het assortiment elders vergelijkbaar is;

7. graag naar Gall \& Gall terug gaan;

8. blij zijn Gall \& Gall verkozen te hebben boven andere aankooppunten;

9. meer om het lot van Gall \& Gall geven; en

10. Gall \& Gall het beste altematief vinden.

In tabel 6.18 worden de waarden voor relatiesterkte (RC) weergegeven. $\mathrm{RC}$ is het ongewogen gemiddelde van de scores van de tien items van de RCQ. Vastgesteld kan worden dat leden significant hoger scoren dan ex-leden. Kortom: leden percipiëren een sterkere relatie met de aanbieder dan ex-leden.

Tabel 6.18 Rellationship Commitment (RC)

\begin{tabular}{|l|l|l|l|l|}
\hline Variabele & Schaal & Leden & En-leden & Sign, muen \\
\hline $\mathrm{RC}$ & $\mathrm{O}$ & 3.15 & 2.66 & $* * * *$ \\
\hline
\end{tabular}

Teneinde ook hier nader inzicht te krijgen in hoe de variabele relatiesterkte is samengesteld wordt Principale Componenten Analyse toegepast op de tien items van de RCQ. Het betreft cen Principale Componenten Analyse met varimax rotatie. Voor de selectie van factoren wordt het gebruikelijke criterium gekozen dat de Eigenwaarde groter dan of gelijk aan 1 is. Principalle Componenten Analyse uitgevoerd op de tien items van de RCQ levert twee factoren op. In tabel 6.19 zijn de factorladingen, die boven .45 liggen, weergegeven. Tevens zijn in deze tabel de Eigenwaarden en het percentage van de variantie, dat door elke factor verklaard wordt, vermeld. Alle items laden op de eerste factor en een aantal items laadt hoog op beide factoren. 
V53. Uw waarden en normen komen sterk overeen met die wan Gullpener.

(ENQ: NOEM ANTWOORDMOGELUKHEDEN)

volledig eens

eens

moch eens, noch oneens

oneens

volledig oneens

(NIET NOEMEN) weet niet/wilkan niet zeggen

V54. U bent er trots op anderen te kunnen vertellen dat U bier van Gulpener koopt.

(ENQ: NOEM ANTWOORDMOGELIKKHEDEN]

wolledig eens

eens

noch eens, noch oneens

oneens

volledig oneens

(NIET NOEMEN) weet niet/wil/kan niet zeggen

V55. Indien het bier maar vergelijkbaar is met dat van Gulpener, koopt U net zo gemakkelijk bier van een andere bierbrouwer.

(ENQ: NOEM ANTWOORDMOGELIJKHEDEN)

volledig eens

cens

noch eens, noch oneens

oneens

volledig oneens

(NIET NOEMEN) weet niet/wil/kan niet zeggen

V56. Gulpemer zet $U$ aan tot het doen van herhalingsaankopen.

(ENQ: NOEM ANTWOORDMOGELIJKHEDEN)

volledig eens

eens

noch eens, noch oneens

oneens

volledig oneens

(NIFT NOEMEN) weet nied wilkan niet zeggen

V57. Er is slechts weinig verandering in $U$ w huidige omstandigheden nodig om wan bier van Gulpener over te stappen op een ander bier.

(ENQ: NOEM ANTWOORDMOGELUKHEDEN)

volledig cens

eens

noch eens, noch oneens

oneens

volledig oneens

(NIET NOEMEN) weet niet/wilkan niet zeggen 
V58. U bent bijnonder blif dal U Gulpener heeft verkozen boven andere brouwerijen. (ENQ: NOEM ANTWOORDMOGELUKHEDEN)

volledig eens

cens

noch eens, noch oneens

oncens

wolledig oneens

(NIET NOEMEN) weet niedwil/kan niet zeggen

V59. U heeft er niet weel voordecl bij indien U klant wan Galpener blijft.

(ENQ: NOEM ANTWOORDMOGELIJKHEDEN)

volledig eens

eens

noch eens, noch oneens

oneens

volledig oneens

(NIET NOEMEN) weet niet/wilkan niet zeggen

V60. U heeft vaak moeite met het beleid van Gulpener naar haar klanten toe.

(ENQ: NOEM ANTWOORDMOGELIJKHEDEN)

volledig eens

eens

noch eens, noch oneens

oneens

volledig oneens

(NIET NOEMEN) weet nieu'wil/kan niet zeggen

V61. U geeft echt om het lot van Gulpener.

(ENQ: NOEM ANTWOORDMOGELIJKHEDEN)

volledig eens

eens

noch eens, noch oneens

oneens

volledig oneens

(NIET NOEMEN) weet niet/wilkan niet zeggen

V62. Voor U is Gulpener het beste altermatief.

(ENQ: NOEM ANTWOORDMOGELIJKHEDEN)

volledig eens

eens

noch eens, noch oneens

oneens

wolledig oneens

(NIET NOEMEN) weet niet/wil/kan niet zeggen 
V63. Het was een verkeerde beslissing om bier van Gulpener te kopen.

(ENQ: NOEM ANTWOORDMOGELIJKHEDEN)

volledig eens

eens

noch eens, noch oneens

oneens

volledig oneens

(NIET NOEMEN) weet niet/wilkan niet zeggen

V64. (ENQ: alleen voor leden Gulpener Biergilde, dus indien V $\square=1$ )

In welke mate heeft de band met Gulpener zich, volgens $U$, gewijagd naar annleiding van Uw lidmatschap van het Gulpener Biergilde? De band met Gulpener is:

(ENQ: NOEM ANTWOORDMOGELIJKHEDEN)

veel sterker geworden

sterker geworden

noch sterker, noch zwakker geworden

zwakker geworden

veel zwakker geworden

(NIET NOEMEN) weet niet/wil/kan niet zeggen

V65. (ENQ: alleen voor ex-leden Gulpener Biergilde, dus indien VI=3)

In welke mate heeft de band met Gulpener zich, volgens $U$, gewijzigd na beeindiging van

Uw Lidmaatschap van het Gulpener Biergilde?

De band met Gulpener is:

(ENQ: NOEM ANTWOORDMOGELIKHEDEN)

veel sterker geworden

sterker geworden

noch sterker, noch zwakker geworden

zwakker geworden

veel zwakker geworden

(NIET NOEMEN) weet niet/wil/kan niet zeggen

Tot slot volgen nog enkele algemene vragen.

V66. (ENQ: VUL GESLACHT IN ZONDER TE VRAGEN)

man

vrouw

(NIET NOEMEN) weet niet/wilkan niel zeggen

V67. Wat is Uw leeftijd?

19 jaar of jonger

20 tot en met 29 jaar

30 tot en met 39 jaar

40 tot en met 49 jaar

50 tot en met 59 jaar

60 tot en met 69 jaar

70 tot en met 79 jaar

80 jaar of ouder

(NIET NOEMEN) weet niet/wil/kan niet zeggen 
V68. Wat is Uw hoogst genoten opleiding?"

(ENQ: KIJK EVENTUEEL OP KAART OPLEIDINGEN)

lager algemeen

lager beroepss

middelbaar algemeen

middelbaar beroeps

hoger algemeen

hoger beroeps

hoger wetenschappelijk

niet duidelijk: (ENQ: NOTEREN)

(NIET NOEMEN) weet niet/wilkan niet zeggen 


\section{BiJlage 2:}

\section{VRAGENLIJST TEN BEHOEVE VAN DE GALL \& GALL STUDIE}

V1. Bent U houder wan de Gall \&all Wijnkaart?

ja, uit persoonlijke interesse (ENQ: Verder met V3)

$\mathrm{ja}_{3}$ uit beroepsmatige interesse (ENQ: Beëindig gesprek)

nee, houder geweest uit persoonlijke interesse (ENQ: Verder met V2)

nee, houder geweest uit beroepsmatige interesse (ENQ: Beëindig gesprek)

(NIET NOEMEN) weet niet/wilkan niet zeggen

V2. Waarom bent $U$ geen houder meer wan de Gall \& Gall Wijnkatart?

Omdat: .....(ENQ: TIK IN)

(NIET NOEMEN) weet niet/wil/kan niet zeggen

(ENQ: Verder met V5)

V3. Sinds wanneer bent 0 houder van de Gall \& Gall Wijukaart?

(ENQ: NOTEER JAARTAL; KODE 98 IS WEET NIETKAN/WIL NIET ZEGGEN EN

ALLES WAT NIET UDTGEDRUKT KAN WORDEN IN EEN JAARTAL)

V4. Waarom bent U houder van de Gall \& Gall Wijnkaart geworden?

Omdat: .....(ENQ: TIK NN)

(NIET NOEMEN) weet niet/wil/kan niet zeggen

V5. Koopt $\mathbf{U}$ wel eens wijn bij Gall \& Gall?

jal

mee (ENQ: verder met V15)

(NIET NOEMEN) weet niet/wil/kan niet zeggen

V6. Hoe lang koopt $\mathrm{U}$ al wijn bij Gall \& Gall, in jaren uitgedrukt?

(ENQ: NOTEER AANTAL JAREN; KODE 98 IS WEET NIETIKAN/WIL NIET ZEGGEN)

v7. Wanneer heeft $U$ voor het laatst wijn bij Gall \& Gall gekocht?

(ENQ: NOEM ANTWOORDMOGELIJKHEDEN)

minder dan 1 week geleden

1 tot 2 weken gelleden

2 tot 3 weken geleden

3 tot 4 weken geleden

langer dan 4 weken geledien

(NIET NOEMEN), weet niet/wil/kan niet zeggen

V8. Hoe waak koopt U wijn bij Gall \& Gall?

(ENQ: NOEM ANTWOORDMOGELIJKHEDEN)

iedere week.

iedere 2 weken

iedere maand

iedere 2 maanden

minder vaak dan iedere 2 maanden

(NIET NOEMEN) weet niet/wil/kan niet zeggen 
V9. Hoevel besteed U gemiddeld per maand aan wijn bỉj Gall \& Gall, in guldens witgedroukt?

(ENQ: NOTEER BEDRAG WN GULDENS; 99998 IS WEET NIET/WILKAN NIET ZEGGEN

Ik lees $U$ mu een aantal stellingen woor. Wilt $U$ mij dan zeggen in hoeverre $U$ het daarmee eens of oneens bent.

V10. U koopt regelmatig wijn bij Gall\&Gall.

(ENQ: NOEM (EVENTUEEL) ANTWOORDNOGELIJKHEDEN)

volledig oneens

oneens

noch eens, noch oreens

wens

volledig eens

(NIET NOEMEN) weet niet/wil/kan niet zeggen

V11. Als U de wijnprijzen wan Gall \& Gall vergelijkt met dle kwalliteit die zij biedt, dan bent $\mathrm{U}$ tevreden over deze prijs/kwaliteit verhouding.

(BNQ: NOEM (EVENTUEEL) ANTWOORDMOGELIJKHEDEN)

volledig oneens

oneens

noch eens, noch oneens

exens

volledig eens

(NIET NOEMEN) weet niet/wil/kan niet zeggen

V12. U bent tevreden over de prijs/kwaliteit verhouding van wijn biji Gall \& Gall vergeleken met de prijs/kwaliteit verhouding van wijn bij andere aankooppunten voor wijn.

(ENQ: NOEM (EVENTUEEL) ANTWOORDMOGELIJKHEDEN)

volledig oneens

oneens

noch eens, noch oneens

cens

volledigeens

(NIET NOEMEN) weet niet/will/kan niet zeggen

V13. Iedere keer nadat U bij Gall \& Gall wijn gekocht heeft, denkt U nog eens na over Uw kewze voor deze slijter.

(ENQ: NOEM (EVENTUEEL) ANTWOORDMOOELIJKHEDEN)

volledig oneens

oneens

noeh eens, noch oncens

eens

volledig eens

(NIET NOEMEN) weet niet/wil/kan niet zeggen

Vh4. Hoeveel \% wan Uw wijnaankopen besteedt $\mathrm{U}$, gemiddeld genomen, bij Gall \& Gall? (ENQ: NOTEER PROCENTEN; 998 IS WEET NIET/WILKAN NIET ZEGGEN)

(ENQ: indien minder dan $100 \%$, ga verder met $\mathrm{V} 16$ (V15 is dan 'ja'); indien gelijk aan $100 \%$, ga verder met V17 (V15 is dan "nee" en V16 is niet van toepassing)) 
V15. Koopt U wel eens wijn bij een ander aanliooppunt dan Gall \& Gall?

ja

nee (ENQ: ga verder met V17)

(NIET NOEMEN) weet niet wilkan miet zeggen

V16. Bij welke van de volgende aankooppuntem, anders dan Gall \& Gall, koopt U wel tens wijn?

(ENQ: NOEM ANTWOORDMOGELIJKHEDEN; MEERDERE ANTWOORDEN MOGELLIJK)

andere slijter

supermarkt

warenhuis

delicatessenwinkel

postorderbedrije (zoals de Wijnbeurs)

ander aankooppunt (ENQ: T"TK IN)

(NIET NOEMEN) weet niet/wil/kan niet zeggen

V17. Koopt $U$ well eens andere produkten dan wijn bij Gall \& Gall?

ja

nee (ENQ: ga verder met tekst vóór V19)

(NIET NOEMEN) weet niet/wil/kan niet zeggen

V18. Welke andere produkten dan wijn koopt U wel eens bij Gall \& Gall?

(ENQ: NOEM ANTWOORDMOGELIJKHEDEN; MBERDERE ANTWOORDEN MOGELIJK)

beerenburg/bitters

bier

cocktails

cognac

frisdranken

jenever

likeur

port

rum

sherry

vietux

whiskey

wodka

andere produkten (ENQ: TIK IN)

(NIET NOEMEN) weet niev wilkan niet zeggen

Tot nu toe gingen de vragen over het kopen bij Gall \& Gall. U kunt ecluter ook op en andere manier in aanraking komen met Gall \& Gall. Denkt $U$ daarbij aan: het spreken met personeel van Gall \& Gall; het lezen over Gall $\&$ Gall; het zien of horen wan reclame-uitingen over Gall \& Gall; thet praten over Gall \& Gall bij familie, wrienden of kennissen; e.d. We moemen dere manieren van in aanraking komen met Gall \& Gall: 'in contact komen met Gall \& Gall'. Hierover gaan de volgende wragen. 
V19. Hoe komt U tegemwoordig in contact met Gall Gall?

(ENQ: NOEM OP; MEERDERE ANTWOORDEN MOGELIJK)

schriftelijk zoals bijwoorbeeld Gall \& Gall magazine en advertenties

telefonisch

mondeling (bijv: met personeel van Gall \& Gall of door gesprekken met anderen over Gall \&

Galli

via radio of $t . v$. (reclamespot)

U kom nuet in contact met Gall \& Gall (ENQ: ga door met tekst vóór V27)

(NIET NOEMEN) weet niet/wil/kan niet zeggen

(ENQ: indien V5 is 'nee" én V17 is 'nee' én V19 is 'niet', dan gesprek voortzetten bij V68: er wordt niets gekocht bij en er is geen contact met Gall \& Gally)

V20. Hoeveel jaren geleden bent $U$ voor het eerst in contact gekomen met Gall \& Gall? (ENQ: NOTEER AANTAL JAREN; 98 IS WEET NIET/WIL/KAN NIET ZEGGEN)

V21. Wanneer bent U woor het laatst in contact gekomen met Gall \& Gall?

(ENQ: NOEM ANTWOORDMOGELIJKHEDEN)

minder dan 1 week geleden.

1 tot 2 weken geleden

2 tot 3 weken geleden

3 tot 4 weken geleden

langer dan 4 weken geleden

(NIET NOEMEN) weet niet/wil/kan niet zeggen

V22. Hoe raak komt $U$ in contact met Gall \& Gall?

(ENQ: NOEM ANTWOORDMOGELJKKHEDEN)

iedere week.

iedere 2 weken

iedere mand

iedere 2 masnden

minder vaak dan ledere 2 maanden

(NIET NOEMEN) weet niet/wil/kan niet zeggen

Ik lees $U$ mu cen aantal stellingen voor. Wilt $U$ mij dan zeggen in hoeverre $U$ het darmee tens of oneens bent.

V23. U komt regelmatig in contact met Gall \& Gall.

(ENQ: NOEM (EVENTUEEL) ANTWOORDMOGELIJKHEDEN)

volledig oneens

oneens

noch eens, noch oneens

eens

volledig eens

(NIET NOEMEN) weet niet/wil/kan niet zeggen 
W24. Zonder een vergelijking te maken met andere aankooppunten beat $U$ tevreden over de contacten met Gall \& Gall.

(ENQ: NOEM (EVENTUEEL) ANTWOORDMOGELIKKHEDEN)

volledig oneens

oneens

noch eens, noch oneens

eens

volledig eens

(NIET NOEMEN) weet nietwil/kan niet zeggen

V25. U bent tevreden over de contacten met Gall \& Gall, als $\mathrm{U}$ deze contacten wei vergelijkt met de contacten met andere aankooppunten.

(ENQ: NOEM (EVENTUEEL) ANTWOORDMOGELIJKHEDEN)

volledig oneens

oneens

noch eens, noch oneens

eens

volledig eens

(NIET NOEMEN) weet niet/wi/kan niet zeggen

V26. Iedere keer nadat $U$ in contact gekomen bent met Gall \& Gall, denkt U daar nog cens over na.

(ENQ: NOEM (EVENTUEEL) ANTWOORDMOGELIJKHEDEN)

volledig oneens

oneens

noch eens, noch oneens

eens

volledig eens

(NIET NOEMEN) weet niet/wil/kan niet zeggen

De volgende vragem hebben betrekking op her kopen bij Gall \& Gall en/of op het op enigerlei wijze in contact komen met Gall \& Gall. Dit zullen we kortweg de band met Gall \& Gall noemen. De band met Gall $\&$ Gall kan op verschillende punten worden beoordeeld. Dantover gaan de volgende vragen.

W27. In welke mate accepteert $U$ incidentele fouten of vergissingen, in $\mathrm{U}$ watled thoor Gall \& Gall gemaakt, voordat $U$ besluit naar een ander aankooppunt over te stappen? (ENQ: NOEM ANTWOORDMOGELIJKHEDEN; NB: ERNST VAN DE FOUT SPEELT GEEN ROL/IS NIET TER ZAKE)

in het geheel niet

in geringe mate

noch in hoge, noch in geringe mate

in hoge mate

in zeer hoge mate

(NIET NOEMEN) weet nietwil/kan niet zeggen 
IK lees $U$ nu een antal stellingen voor. Wilt $U$ mij dan zeggen in hoeverre $U$ het daarmee eens of oneens bent.

V28. Het beeindigen van de band met Gall \& Gall brengt woor U risico's met xich nee (bifyoorbeeld met betrekking tot werkrijgbaarheid van produkten, mening van Uw wienden).

(ENQ: NOEM (EVENTUEEL) ANTWOORDMOGELIJKHEDEN)

volledig oneens

oneerns

noeli eens, noch oneens

eens

volledig eens

(NIET NOEMEN) weet niet/wil/kan niet zeggen

V29. Het aangaan van een band met een ander ankooppunt dan Gall \& Gall brengt woor $\mathrm{U}$ risico's met xich mee (bijvoorbeeld: de mate waarin produkt voldoet aan Uw verwachtingen; onbekendheid net produktaanbod en kwaliteit van de dienstverlening). (ENQ: NOEM (EVENTUEEL) ANTWOORDMOGELIJKHEDEN)

volledig oneens

oneens

noch eens, noch oneens

eens

volledig eens:

(NIET NOEMEN) weet niet/wil/kan niet zeggen

V30. Het beeindigen wan de band met Gall \& Gall brengt voor U kosten met zich mee of vraagt om een inspanning (bijvoorbeeld als gevollg van het zoeken naar een ander aankooppunt). (ENQ: NOEM (EVENTUEEL) ANTWOORDMOGELIJKHEDEN)

volledig oneens

oneens

noch eens, noch oneens 3

eens 4

volledig eens 5

(NIET NOEMEN) weet niet/wil/kan niet zeggen 8

V31. Het aangaan van een band met een ander ankooppunt dan Gall \& Gall brengt woor $U$

kosten met zich mee of vraagt om een inspanning (bijwoorbeeld als gevolg van een langere reistijd).

(ENQ: NOEM (EVENTUEEL) ANTWOORDMOGELIJKHEDEN)

volledig oneens

oneens

noch eens, noch oneens

eens

volledig eens

(NIET NOEMEN) weet niet/wilkan niet zeggen 
V32. U heeft er geen problemen mee om de band met Gall \& Gall te beëindigen.

(ENQ: NOEM (EVENTUEEL) ANTWOORDMOGELUKHEDEN)

volledig oneens

oneens

noch eens, noch oneens

eens

volledig eens

(NIET NOEMEN) weet niet/wil/kan niet zeggen

V33. U heeft er geen problemen mee om een band met een ander aankooppunt dan Gall \& Gall aan te gaan.

(ENQ: NOEM (EVENTUEEL) ANTWOORDMOGELINKHEDEN)

volledig oneens

oneens

noch eens, noch oneens

eens

volledig eens

(NIET NOEMEN) weet niet $/$ wil $/ \mathrm{kan}$ niet zeggen

V34. In geval van incidentele fouten of vergissingen, in Uw nadeel door Gall \& Gall gemaakt, gaat $U$ over tot het indienen van een klacht bij Gall \& Gall.

(ENQ: NOEM (EVENTUEEL) ANTWOORDMOGELIJKHEDEN)

volledig oneens

oneens.

noch eens, noch oneens

eens

volledig eens

(NIET NOEMEN) weet niet/wil/kan niet zeggen

V35. Ik noem nu een aantal manieren waarop de band met Gall \& Gall omschreven kan worden. Welke daarvan geeft Uw huidige band met Gall \& Gall het beste weer?

(ENQ: NOEM EERST OP EN HERHAAL VERVOLGENS DE ANTWOORDMOGELIJKHEDEN)

Gall \& Gall informeert $U$ wel, mar vaagt $U$ miet om een reactic.

Gall \& Gall nodigt U uit on contact met haar op te nemen als $U$ vragen of klachten heef.

Gall \& Gall informeert enige tijd ná de ankoop of $U$ tevreden bent.

Gall \& Gall neemt van tijd tot tijd contact met $U$ op en toont interesse in $U$.

Gall \& Gall zoekt samen met U naar antwoorden op Uw vragen, produktwerbeteringen en/of specifieke of nieuwe produkiten.

(NIET NOEMEN) weet niet/wil/kan niet zeggen

V36. Bent $U$ wan plan om in de toekomst bij Gall \& Gall te (blijven) kopen?"

ja

nee (ENQ: ga verder met tekst vóo V38)

(NIET NOEMEN) weet niet/wil/kan niet zeggen 
V37. Ik mgem wil cen aantal manieren waarop de band met Gall \& Gall omschreven kan worden. Welke daaryan geeft de door U gewenste band anet Gall \& Gall het beste weer? (ENQ: NOEM EERST OP EN HERHAAL DE ANTWOORDMOGELLKKHEDEN)

$U$ wenst met dat Gall \& Gall $U$ informeert en an $U$ om een reactie vraagt.

U wenst dat Gall \& Gall U uitrodigt om contact met has op te nemen als U vragen of klachten heeft.

U wenst dat Gall ${ }^{2}$ Gall enige tijd ná de aankoop informeent of U tevreden bent.

$U$ wenst dat Gall \& Gall wan thijd tot tijd contact met $U$ opneemt en interesse in $U$ toont. 4

U wenst dat Gall \& Gall samen met U naar antwoorden op Uw vragen, produktwerbeteringen en/of specifieke of nieuwe produkten zoekt.

(NIET NOEMEN) weet niet/wil/kan niet zeggen

Ik lees $U$ mu enkelle stellingen woor. Wilt $U$ mij dan steeds zeggen in hoeverre $U$ het daarmee eens of oncers bent.

V38. U kunt er op rekenen dat Gall \& Gall U eerlijk beliandelt.

(ENQ: NOEM (EVENTUEEL) ANTWOORDMOGELIJKHEDEN)

wolledig oneens

oneens

noch eens, noch oneens.

eens

wolledig cens

(NIET NOEMEN) weet niet/wilkan niet zeggen

V39. Er zijin situaties geweest waarin U het gevoel had door Gall \& Gall tekort gedaan te worden.

(ENQ: NOEM (EVENTUEEL) ANTWOORDMOGELUKHEDEN)

volledig oneens

oneens

noch eens, noch oneens

eens

volledig eens

(NIET NOEMEN) weet niet/wil/kan niet zeggen

V40, U heeft vertrouwen in Gall \& Gall.

(ENQ: NOEM (EVENTUEEL) ANTWOORDMOGELIIKHEDEN)

volledig oneens

oneens

noch eens, noch oneens

cens

volledig eens

(NIET NOEMEN), weet niet/wil/kan niet zeggen

V41. Ukiest zorgvuldig een bepaald aankooppunt voor wijn uit.

(ENQ: NOEM (EVENTUEEL) ANTWOORDMOGELIJKHEDEN)

volledig oneens

oneens

noch eens, noch oneens

eens

volledig eens

(NIET NOEMEN) weet niet/wil/kan niet zeggen 
V42. Het kan U nuet schelen welk aankooppunt voor wijn $U$ kiest.

(ENQ: NOEM (EVENTUEEL) ANTWOORDMOGELIJKHEDEN)

volledig oneens

oneens

noch eens, noch oneens

eens

volledig eens

(NIET NOEMEN) weet niet/wil/kan niet zeggen

V43. Voor $U$ persoonlijk is de keuze van een bepaald aankooppunt voor wijn niet relevant.

(ENQ: NOEM (EVENTUEEL) ANTWOORDMOGELIKHEDEN)

volledig oneens

oneens

noch eens, noch oneens

eens

volledig eens

(NIET NOEMEN) weet niet/wil/kan niet zeggen

V44. In het algemeen bent $U$ tevreden met Gall \& Gall als aankooppunt.

(ENQ: NOEM (EVENTUEEL) ANTWOORDMOGELIJKHEDEN)

volledig oneens

oneens

noch eens, noch oneens

eens

volledig eens

(NIET NOEMEN) weet niet/wil/kan niet zeggen

V45. Over het geheel gezien is Gall \& Gall een goede organisatie om aankopen te doen.

(ENQ: NOEM (EVENTUEEL) ANTWOORDMOGEILIKKHEDEN)

volledig oneens

oneens

noch eens, noch oneens

eens

volledig eens

(NIET NOEMEN) wet niet/wil/kan niet zeggen

V46. Fr is geen andere organisatie die zo'm uitgebreid assortiment an dranken aabiedt alls Gall \& Gall.

(ENQ: NOEM (EVENTUEEL) ANTWOORDMOGELIJKHEDEN)

wolledig oneens

oneens

noch eens, noch oneens

eens

volledig eens

(NIET NOEMEN) weet niet/wil/kan niet zeggen 
V47. Een aalntal produkten is alleen bij Gall \& Call verkrijgbaar.

(ENQ: NOEM (EVENTUEEL) ANTWOORDMOGELIJKHEDEN)

volledig oneens

oneens

noch eens, noch oneens

eens

wolledig tens

(NET NOEMEN) weet nied/wil/kan niet zeggen

V48. Voor een goed advies op het gebied van wijn gaat $U$ altijd naar Gall \& Gall. (ENQ: NOEM (EVENTUEEL) ANTWOORDMOGELIJKHEDEN)

wolledig oneens

oneens

noch eens, noch oneens

eens

volledig eens

(NIET NOEMEN) weet niet/wilkan niet zeggen

V49. Andere aankooppunten woor wije kunnen U beter adviseren dan Gall \& Gall. (ENQ: NOEM (EVENTUEEL) ANTWOORDMOGELIJKHEDEN)

volledig oneens

oneens

noch eens, noch oneens

eens

volledig eens

(NIET NOEMEN) weet niet/wil/kan niet zeggen

V50. U verwacht in de toekomst meer bij Gall \& Gall te bestedlen dan nu het gevall is. (ENQ: NOEM (EVENTUEEL) ANTWOORDMOGELIJKHEDEN)

volledig oneens

oneens

noch eens, noch oneens

eens

volledigeens

(NIET NOEMEN) weet niet/wil/kan niet zeggen

V51. Bij het kopen van wijn neemt U naast Gall \& Gall ook andere aankooppunten in beschouwing.

(ENQ: NOEM (EVENTUEEL) ANTWOORDMOGELIJKHEDEN)

volledig oneens

oneens

noch eens, noch oneens

eens

volledig eens

(NIET NOEMEN) weet niet/wil/kan niet zeggen 
Dan volgen nu nog enkele stellingen. Deze hebben betrekking op Gall Gall in het algemeen. Wilt $U$ mij telkens zeggen in hoeverre U het darmee cens of oneens bent:

V52. U bent bereid extra moeite te doen on bij Gall $\&$ Gall te kunnen kopen.

(ENQ: NOEM (EVENTUEEL) ANTWOORDMOGELIJKHEDEN)

volledig oneens

oneens

noch eens, noch oneens

eens

volledig eens

(NIET NOEMEN) weet nietwil/kan niet zeggen

V53. U beveelt Gall \& Gall aan bij Uw vrienden als een organisatie die dranken van goedle kwaliteit verkoopt.

(ENQ: NOEM (EVENTUEEL) ANTWOORDMOGELIJKHEDEN)

volledig oneens.

oneens

noch eens, noch oneens

eens

volledig cens

(NIET NOEMEN) weet niet/wil/kan niet zeggen

V54. U bent niet erg trouw aan Gall \& Gall.

(ENQ: NOEM (EVENTUEEL) ANTWOORDMOGELIJKHEDEN)

volledig oneens

oneens

noch eens, noch oneens

eens

volledig eens

(NIET NOEMEN) weet niet/wil/kan niet zeggen

V55. U zou een prijswerhoging van 5\% accepteren, en bij Gall \& Gall blijven kopen.

(ENQ: NOEM (EVENTUEEL) ANTWOORDMOGELIJKHEDEN)

volledig oneens

oneens

noch eens, noch oneens

eens

volledig eens

(NIET NOEMEN) weet nietwilkan niet zeggen

V56. Uw waarden en mormen komen sterk overeen met die van Gall \& Gall.

(ENQ: NOEM (EVENTUEEL) ANTWOORDMOGELIIKHEDEN)

volledig oneens

oneens

noch eens, noch oneens

eens

volledig eens

(NIET NOEMEN) weet net/wilkan niet zeggen 
V57. U bent er trots op anderen te konnen vertellen dar U bij Gall \& Gall koopt. (ENQ: NOEM (EVENTUEEL) ANTWOORDMOGELIKHEDEN)

volledig oneens

oneens

noch eens, noch oneens

cens

volledig eens

(NIET NOEMEN) weet niet/wil/kan niet zeggen

V58. Zolang het assortiment maar vergelijkbaar is met dat van Gall \& Gall, koopt $U$ net zo gemakkelijk bij cen ander aankooppunt.

(ENQ: NOEM (EVENTUEEL) ANTWOORDMOGELIJKHEDEN)

volledig oneens

onteens

noch eens, noch oneens

eens

volledig eens

(NIET NOEMEN) weet nict/wil/kan niet zeggen

V59. Naar Gall \& Gall gaat U gragg terug.

(ENQ: NOEM (EVENTUEEL) ANTWOORDMOGELIJKHEDEN)

volledig oneens

oneens

noch eens, noch oneens

eens

volledig eens

(NIET NOEMEN) weet niet/wilkan niet zeggen

V60. Er is slechts weinig verandering in Uw huidige omstandigheden nodigg om van het kopen bij Gall \& Gall over te stappen op een ander aankooppunt.

(ENQ: NOEM (EVENTUEEL) ANTWOORDMOGELIJKHEDEN)

volledig oneens

oneens

noch eens, noek oneens

cens

volledig eens

(NIET NOEMEN) weet miet/wil/kan niet zeggen

V61. U bent blij dat U Gall \& Gall heeft verkozen boven andere aankooppunten.

(GNQ: NOEM (EVENTUEEL) ANTWOORDMOGELIJKHEDEN)

volledig oneens

oneens

noch eens, noch oneens

eens

volledige ens

(NIET NOEMEN) weet nied/wil/kan niet zeggen 
V62. U heeft er niet veel roordeel bij indien U klant van Gall \& Gall blift. (ENQ: NOEM (EVENTUEEL) ANTWOORDMOGELIJKHEDEN)

volledig oneers.

oneens

noch eens, noch oneens

eens

volledig eens

(NIET NOEMEN) weet niet/wil/kan niet zeggen

V63. U heeft vaak moeite met her beleid van Gall \& Gall naar haar klanten toe. (ENQ: NOEM (EVENTUEEL) ANTWOORDMOGELIJKHEDEN)

volledig oneens

oneens

noch eens, noch oneens

eens

volledig eens

(NIET NOEMEN) weet niet/wil/kan niet zeggen

V64. U geeft echt om het lot van Gall \& Gall.

(ENQ: NOEM (EVENTUEEL) ANTWOORDMOGELIMKHEDEN)

volledig oneens.

oneens

noch eens, noch oneens

cens

volledig eens

(NIET NOEMEN) weet niet/wil/kan niet zeggen

V65. Voor $\mathrm{U}$ is Gall \& Gall het beste alternatief.

(ENQ: NOEM (EVENTUEEL) ANTWOORDMOGELIJKHEDEN)

volledig oneens

oneens

noch eens, noch oneens

eens

volledig eens

(NIET NOEMEN) weet niet/wil/kan niet zeggen

V66. Het was een verkeerde beslissing om bij Gall \& Gall te kopen.

(ENQ: NOEM (EVENTUEEL) ANTWOORDMOGELIJKHEDEN)

volledig oneens

oneens

noch eens, noch oneens

eens

volledig eens

(NIET NOEMEN) weet niet/wil/kan niet zeggen 
V67. (ENQ: alleér voor houders van de Gall \& Gall Wijnkaart, m.a.w indien V1=1)

In welke mate heeft de band met Gall \& Gall zich, wolgens $U$, gewijzigd naar aanleiding wan Uw houderschap van de Gall \& Gall Wijnkaart?

De band met Gall d Gall is natr anleiding van het Wijnkaarthouderschap: (ENQ: NOEM ANTWOORDMOGELIJKHEDEN)

veel zwakker geworden

zwakker geworden

hetzellde gebleven

sterker geworden

weel sterker geworden

(NIET NOEMEN) weet niet/wi/kan niet zeggen

V68. (ENQ: allén voor ex-houders van de Gal] \& Gall Wijnkart, m.a.w.; indien VI=3)

In welke mate heeft de band met Gall \& Gall zich, volgens $U$, gewijzigd na beëindiging wan Uw houderschap van Gall \& Gall Wijakaart?

De band met Gall \& Gall is na beëindiging van het Wijnkaarthouderschap:

(ENQ: NOEM ANTWOORDMOGELIJKHEDEN)

veel zwakker geworden

zwakker geworden

hetzelfde gebleven

sterker geworden

veel sterker geworden

(NIET NOEMEN) weet niet/wil/kan niet zeggen

V69. Wat is Uw oordeel over de prijs (f 17,50) van de Gall \& Gall wijnkaart?

Vindt $\mathrm{U}$ die.....?

(ENQ: NOEM OP)

zeer goedkoop

tamelijk goedkoop

goed

tamelijk duur

zeer duur

(NIET NOEMEN) weet niev/wil/kan niet zeggen

Tot slot volgen nog enkele algemene vragen.

V70. (ENQ: VUL GESLACHT IN ZOWDER TE VRAGEN, BIJ TWIJFFL VRAGEN)

man

vrouw

onduidelijk

V71. Wat is Uw leefijd?

19 jaar of jonger

20 tot en met 29 jaar

30 tot en met 39 jaar

40 tot en met 49 jaar

50 tot en met 59 jaar

60 tot en met 69 jaar

70 tot en met 79 jaar

80 jaar of ouder

(NIET NOEMEN) weet niet/wilkan niet zeggen 
V72. Wat is Uw hoogst genoten opleiding?

(ENQ: KIJK EVENTUEEL OP KAART OPLEIDNONEN)

lager algemeen

lager beroeps

middelbaar algemeen

middellbaar beroeps

hoger algemeen

hoger beroeps

hoger wetenschappelijk

niet duidelijk (ENQ: INTIKKEN)

(NIET NOEMEN) weet niet/wilkan niet zeggen 


\section{BiJlage 3:}

\section{ANTWOORDEN OPEN VRAGEN GALL \& GALL STUDIE}

Een korte inventarisatie van de antwoorden op de twee open vagen is weergegewen in de tabellen I en II. Een respondent kon meerdere redenen opgeven.

Tabel BI Open vraag 2: Waarom geen houder meer?

\begin{tabular}{|l|c|}
\hline Reden & Frequentie \\
\hline Niet meer rendabel / geen voordeel meer & 44 \\
\hline Te weinig gebruik gemaakt van wijnkart & 39 \\
\hline Naar concurrent & 35 \\
\hline Kaart verlopen & 19 \\
\hline Niet in de buurt / bereikbaarheid & 18 \\
\hline Drinkt niet meer & 11 \\
\hline Geen interesse meer & 6 \\
\hline Weinig wijn bij Gali \& Gall & 3 \\
\hline Verplicht voelen & 2 \\
\hline Irritant systeem & 2 \\
\hline
\end{tabular}

Tabel BII Open vraag 4: Waarom houder geworden?

\begin{tabular}{|l|c|}
\hline Reden & Frequentie \\
\hline Voordelig/ kortingen en aanbiedingen & 156 \\
\hline Drinkt / koopt veel wijn & 43 \\
\hline Informatie & 37 \\
\hline Interesse & 14 \\
\hline Goede wijnen bij Gall \& Gall & 13 \\
\hline In de bunt / dichtbij & 9 \\
\hline Makkelijk & 4 \\
\hline Opgedrongen & 3 \\
\hline
\end{tabular}




\section{BiJllage 4:}

\section{DE RELATIE AUDIT VAN WILSON (1990)}

1. Hoe teveden is de afnemer over de geleverde hwalliet?

Matig tevreden

12

23
Zest tevreden

4

5

2. Hoe reveden is de afnemer over de getewerde prijshwalieir merhouding?

Matig tevreden

1
2
3
Zeer teveden

5

3. Her vertrouwen van de afnemer in ons is re onschijuen ats:

Alles wordi schriftelijk

vastgelegd

1
2
We houden ons atrit ons woord

\section{5}

4. Het verifowwen wan de affemen in ons is te onschrijuen als:

We delen weinig

We delen openlijk informatie informatio

1 2 3

4

5. We zijn overeengekomen op welke wize wij eventuele conflicten in onzer relatis oplossen:

Enigszins mee eens

I
2

3
Volledig mee cens

4

\section{5}

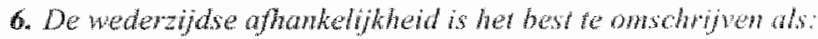

1. Wij zijn zeer aharkelijk van de afnemer

2. Wij zijn enigszins afhankelijk van de afnemer

3. De afnemer en wij zijn even afhankelijk wan elkaar

4. De afnemer is enigszins afhankelik van ons

5. De afnemer is zeer afhankelijk van ons

7. De relatie han het best gekarahteriseerd worten als:

Formele zakenrelatie

Zakenwrienden

Zeor goede persoonligke visenden 
8. De afnemer kan ons genakkelijk vervangen door een andere leverancier die vergelijkbare prestaties levert:

Volledig mee ens

1
2

Volledig mee oneens 3 4 5

9. Welke van de wolgende beweringen beschrijft het best het miveau van betrokkenheid in onze relatie met de afnemer?

1. Wederzijds zijn er één of twee contactpersonen op lager niveau bij betrokken

2. Wederzijds zijn er meerdere contactpersonen op lager niveau bij betrokken

3. Wederzijds zijin er enkele contactpersonen op verschillende niveaus bij betrokken

4. Wederzijds zijn er meerdere contactpersonen op verschillende niveaus bij betrokken

5. Wederzijds zijn er meerdere contactpersonen van verschillende afdelingen bij betrokken, inclusief het hoogste niveau

10. Hoe warschijnlijk is het dat als uw contactpersoon de relatie met ons wil beeindigen er vanut de afnemer sociale druk op hem wordt uitgeoefend om dit niet te doen?

Zeer waarschijndijk

1
2
Niet erg waarschijnlijk

4
5

11. Hoe genakkelijk is her voor de afnemer om de relatie met ons te beeindigen?

Zeer gemakkelijk

1
2
Kost meer dan een jaar

5

12. In welke mate heeft de afnemer investeringen gemaakf die alleen waarde hebben in een relatie met ons?

Helemaal niet

In zeer grote mate

l

2

3

4 5

Toelichting: Wilson (1990) beschouwt een totalscore tot en met 35 punten als cen indicatie voor een zwakke relatie; $36-46$ punten als een gemiddeld sterke relatie; $47-53$ punten als een redelijk sterke relatie; 54-60 punten als een zeer sterke relatie.

Bronnen: Wilson (1990); Steenkamp (1991) 


\section{BiJlage 5:}

\section{DE ORGANiZATIONAL COMMITMENT QUESTIONNAIRE (OCQ)}

1. I am willing to put in a great deal of effort beyond that normally expected in order to help this organization be successful.

2. I talk up this organization to my friends as a great organization to work for.

3. If feel very little loyalty to this organization. (R)

4. I would accept almost any type of job assignment in order to keep working for this organization.

5. If find that my values and the organization's values are very similar.

6. I am proud to tell others that I am part of this organization.

7. $\mathbb{I}$ could just as well be working for a different organization as long as the type of work was similar. (R)

8. This organization really inspires the wery best in me in the way of job performance.

9. It would take very little change in my present circumstances to cause me to leave this organization. (R)

10. I am extremely glad that I chose this organization to work for over others I was considering at the time I joined.

11. There's not too much to be gained by sticking with this organization indefinitely. (R)

12. Often, $I$ find it difficult to agree with this organization's policies on important matters relating to its employees. (R)

13. If really care about the fate of this organization.

14. For me this is the best of all possible organizations for which to work.

15. Deciding to work for this organization was a definite mistake on my part. (R)

Toelichting: antwoordmogelijkheden bestonden uit 7-punts Likert-Schalen met als ankerpunten;

(1) strongly disagree; (2) moderately disagree; (3) slightly disagree; (4) neither disagree nor agree;

(5) slightly agree; (6) moderately agree; (7) strongly agree.

Een (R) duidt op een negatief geformuleerd item watarvor de score omgekeerd wordt.

Bron: Mowday et al. (1979) 


\section{BIJLAGE 6:}

\section{VERGELIJKING RESPONDENTEN IN HET KADER VAN SELECTION BIAS ALS GEVOLG VAN ITEM NON-RESPONSE}

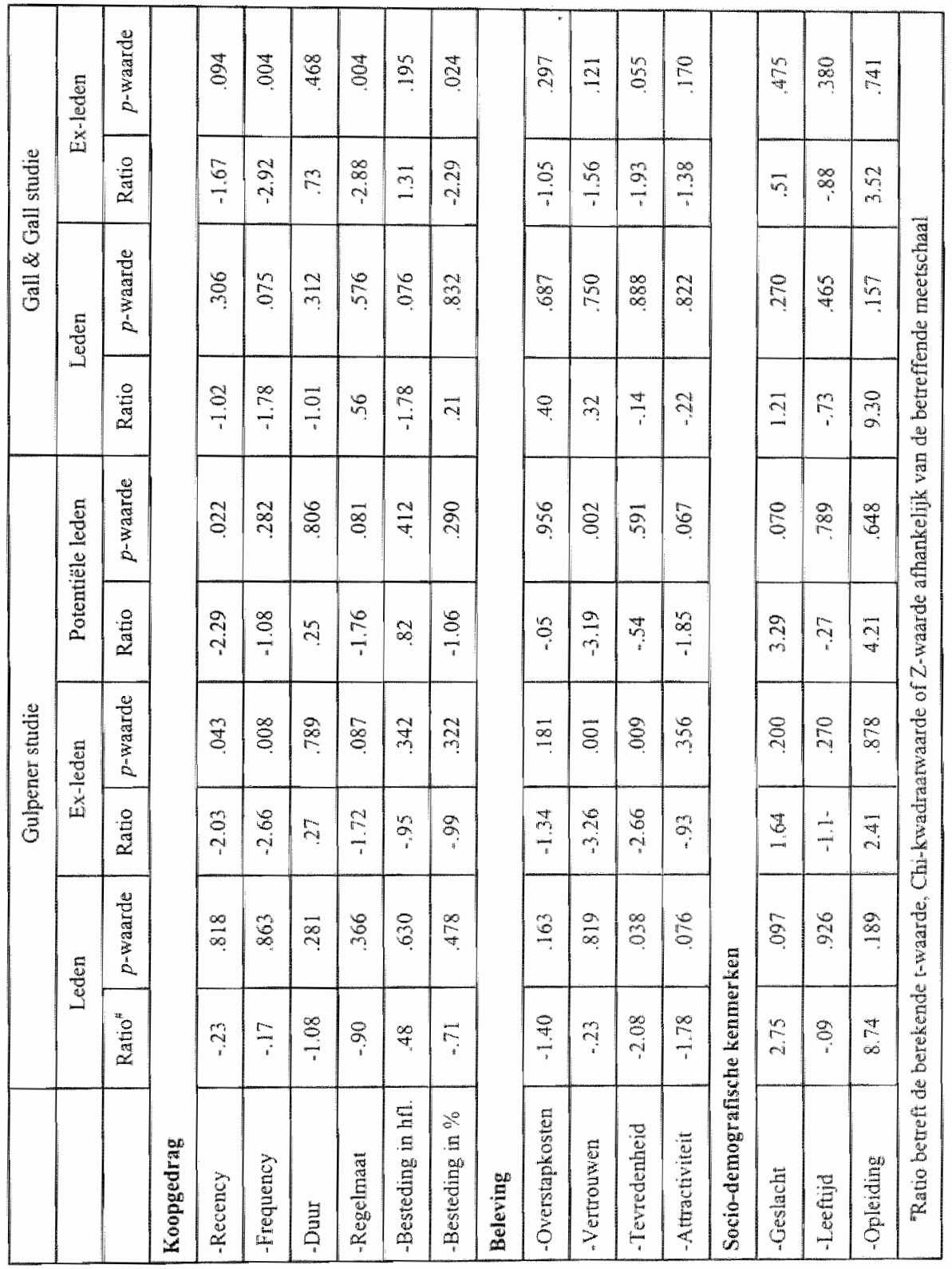




\section{GERAADPLEEGDE LITERATUUR}

\section{A}

ABRAHAM, M.M. en Lodish, L.M. (1987), "PROMOTOR: An Automated Promotion Evaluation System", Marketing Science, jrg. 6, no. 2, pp. 101-123

ACHROL, R. (1991), "Evolution of the Marketing Organization: New Forms for Turbulent Enviromments", Journal of Marketing, jrg. 55, no. 4, pp. 77-93

ALBERTS, P. en Buitendijk, N. (1995a), Relatiemarketing: Hoe het ech werk, G.V.R.-monogratie, no. 2 , januari

ALBERTS, P. en Buitendijk, N. (1995b), "Aandacht uit zelfbehoud: Relaties met klanten ontwikkelen in drie stappen", Tijdschrift woor Marketing, jrg. 29, no. 3 (maart), pp. 47.52

ALLEN, N.J. en Meyer, J.P. (1990), "The measurement and antecedents of affective, continuance and normative commitment to the organization", Joumal of Occuparional Psychology, jrg, 63, pp. 1. 1.8

ANDERSON, J.C. en Narus, J.P. (1986), "Towards a Better Understanding of Distribution Channet Working Relationships", in: Backhaus, K. en Wilson, D. (eds.), Industrial Marketing; A German-American Perspective, Springer-Verlag, Berlin, pp. $320-336$

ANDERSON, J.C. en Weitz, B. (1989), "Determinants of Continuity in Conventional Industrial Channel Dyads", Markering Science, no. 8 (Fall), pp. 310-323

ANDERSON, J.C. en Narus, J.P. (1990), "A Model of Distributor Firm and Manufacturer Firm Working Partnerships", Jowrnal of Marketing, jrg. 54, no. 1 (January), pp. $42-58$

ANDERSON, J.C. en Niarus, J.P. (1991a), "Be Picky When Partnering", ISBM Insights, jrg. 1, no. I

ANDERSON, J.C. en Nanus, J.P. (1991b), "Partnering as a Focused Market Strategy", California Management Review, (Spring), pp. 95-113

ANDERSON, J.C. en Weitz, B. (1992), "The Use of Pledges to Build and Sustain Commitment in Distribution Channels", Journal of Marketing Research, jrg. 24, no. February, pp. 18-34

ARNDT, J. (1979), "Toward a Concept of Domesticated Markets", Jotinal of Marketing, jrg. 43, Fall, pp. 69-75

$\mathbf{B}$

BAGOZZI, R.P. (1994), Principles of Marketing Research, Blackwell, Cambridge

BAIER, M. (1985), Elements of Direct Marketing, McGraw-Hill, New York

BARLOW, R.G. (1992), "Relationship Marketing - The Ultimate in Customer Services", Retail Control, maart, pp. 29-37

BARNES, J.G. (1994), "Close to the Customer: but is it Really a Relationship?", Jowrnal of Markemg Management, jrg. 10, pp. $561-570$

BARNES, J.G. (1995), "The Quality and Dopth of Customer Relationships", in: Bergadaà, M. (red.). Proceedings of the 24th EMAC Conference, Essec, Cergy-Pontoise, pp. 1393-1402

BAUER, C.L. en Miglautsch, J. (1992), "A Conceptual Definition of Direct Marketing", Journal of Direct Marketing, jrg. 6, no. 2 (Spring), pp. 7-17

BEARDEN, W.O., Netemeyer, R.G. en Mobley, M.F. (1993), Handbook of Marketing Scales: MultiItem Measures for Marketing and Consumer Behavior Research, SAGE in cooperation will the Association for Consumer Research, London

BEATTY, S.E., Homer, P. en Kahle, L.R. (1988), "The involvement * commitment model, theory and implications", Journal of Bustiness Research, jrg. 16, pp. 149-167 
BEJOU, D. Wray, B. en Ingram, T.N. (1996), "Deteminants of Relationship Quality, An Artifial Ncural Network Analysis", Joumal of Business Research, jrg. 36, pp. 137-143

BELSON, W.A. (1986), Walidity in Survey Research, Gower, Aldershot Hants

BERRY, L.L. (1983), "Relationship Marketing", in: Betry, L.L., Shostack, G.L. en Upah. G.D. (eds.), Energing Perspectives on Services Marketing, American Marketing Association, Chicago, In., pp. $25-28$

BERRY, L.L. (1995), "Relationship Marketing of Services: Growing Inierest, Emerging Perspectives", Journal of the Acadeny of Marketing Science, jrg. 23, no. 4 (oktober), pp. 236-245

BERRY, L.L. en Gresham, L.G. (1986), "Relationship Retailing: Transforming Customers into Clients: Business Horizons, november-december, pp. 43-47

BERRY, L.L. en Parasuraman, A. (1991), Marketing Sevices: Competing Through Quality, The Free Press, New York, pp. 132-150

BEUKENKAMP, P.A. Leflang, P.SH. (1988a), "Direct Marketing", in: Leeflang, P.S.H. (red.), Probleemvelden in Marketing, band II van: Probleemgebied marketing: een managementbenadering, Stenfert Kroese, Leiden/Antwerpen

BEUKENKAMP, P.A. en Leellang, P.S.H. (1988b), "Het specifieke van direct marketing (1): Inlejding en de omgeving", Maandblad voor Accountancy en Bedriffseconomie, jrg. 62, no. 9 (september), pp. $378-388$

BIEMANS, N. (1997), Relatienarketing voor charitaieve instellingen: her meten van de relatiesterkte, doctoraalseriptic Universiteit Maastricht, FdEWB, Maastricht

BLATTBERG, R.C. en Levin, A. (1987), "Modeling the Effectiveness and Profitability of Trade Promotions", Marketirig Science, jrg. 6, no. 2, pp. 124-146

BLATTBERG, R.C. en Deighton, J. (1991), "Interactive Marketing: Exploiting the Age of Addressability", Sloan Management Review, jrg. 33, no. 1 (Fall), pp. 5- 14

BLIEMEL, F.W. en Eggert, A. (1998), "Kundenbindung: die neue Sollstrategie", Marketing. Zeitschriff für Forschung und Praxis, jrg. 20, no, 1 (1. Quartal), pp. 37-46

BLIJENBERG, L.M., Raaij, W.F. van en Vermeulen, R.A.M. (1996), Atrente, attentie ... retentie! Over relatiemanketing programma's gesproken, Executive summary, DMSA, Amsterdam, oktober

BLOEMER, J.M.M. (1990), "Herhalingsaankopen en nerkentrouw", Tijdschrift voor Marketing, jrg. 24, no. 12 (december), pp. $96-100$

BLOEMER, JM.M. (1993a), Loyaliteit en tevredenhed, een studie nadr de relatie tussen merktrouw an consumententewedewheid, proefschrift, Universitaire Pers, Maastricht

BLOEMER, J.M.M. (1993b), "Ware merktrouw cn tevredenheid van klanten", Tijdschriff woor Marketing, jrg. 27, no. 12 (december), pp. 38-42

BLOEMER, J.M.M. (1994), "Merktrouw en merkwaardering", MAB, jrg. 68, no. 11 (novenber), pp. $642 \times 648$

BLOMMAERT, I.M.J. en Blomnaert, A.M.M. (1986), Woorgezethe fnanciële administratie, Stenfert. Kroese, Leiden/Anwerpen

BOER, D. de en Waats, E. (1997), "Verbondenheid als basis voor loyaal koopgedrag", Tijdschrift woor Markering, jrg. 31, no. 6 (juni), pp. 22-27

BRUHN, M. en Bunge, B. (1994), "Beziehungsmarketing - Neuorientierung für Marketingwissenschati und -praxis?". Arbeispapiere des Institus fip Marketing an der Buropean Business School, no. 15, Schloss Reichartshausen/Rheingau

BUIGHOLT, J., Nouhuys, R.J. wan en Plat, F. (1996a), "Klantprogramma's: sleutel tot klantenbinding", Adfodrect Magazine, no. 5/6 (mei/juni), pp. 60-61

BUIGHOLT, J., Noutuys, R.J. van en Plat, F. (1996b), "Klantprogramma's: sleutel tot klantenbinding (slot)", Adfodirect Magazine, no. 7 (juli), pp. $55-56$

BUNK, B. (1992) "Fluktuation minimieren. Was Kunden bindet", Absazwirtschaft, no. 4, pp. $36-47$

BUNT, I. Ekelmans, C.F.W. en Peelen, E. (1987), "Direct narketing bij toenemende indiwidualisering van de wag." Brochwe Zelfregulering Individu en Overheid, DMIN, Amsterdam, pp. 28-38 
BUNT, J. en Tettero, J.H.J.P. (1987), "Kwalificerende marketing", Twdschrit woor Markethg. jrg. 21 , no. 4 (april), pp. 104-112

BURGERS, J.A.H. (1997), Relatiebeheer als groeistrategie, Kluwer, Dewenter

BUTSCHER, S. (1996), "Welcome to the club", Tijdschrif woor Markenting, jrg. 30, no. 9 (september), pp. $57-59$

BUTTLE, F. (ed.) (1996), Relationship Marketing: Theory and Practice, Paul Chapman, London

C

CAMPBELL, D.T. en Fiske, D.W. (1959), "Convergent and ciscriminant validation by the multitraitmultimethod matrix", Psychological Bulletm, jrg. 56, pp. 81-105

CAMPBELL, N.C.G. (1985), "An Interaction Approach to Organizational Buying Behavior", fournal of Business Research, jrg. 13, pp. 35-48

CANNON, J.P. en Sheth, J.N. (1994), "Developing a Curriculum to Enhance Teaching of Relationship Marketing", Jounal of Marketing Education, Summer, pp. 3-14

CHRISTOPHER, M., Payne, A. en Ballantyne, D. (1991), Relationship markethy; Bringing quality, customer service and marketing together, Butterworth-Heinemann, Ox ford

CHRISTY, R., Oliver, G. en Penn, J. (1996), "Relationship Marketing in Consumer Markets", Journal of Marketing Management, jrg. 12, no. 1, pp. 175-187

CHURCHILL, G.A. Jr. (1995), Marketing Research, methodological foundations, 6th. ed., Forth Worth, The Dryden Press

COOTE, L.C. (1996), "Benefits and Commitment in Buyer-Vendor Relationships", in: Sheth, J.N. en Söllner, A. (red.), Development, Management and Governance of Relationships, International Conference on Relationship Marketing, 29-31 maart 1996 te Berlijn, pp. 177-189

COPULSKY, J.R. en Wolf, M.J. (1990), "Relationship Marketing: Positioning for the Future", The Jownal of Business Strategy, July/August, pp. 16-20

CRAIG-LEES, M. en Caldwell, M. (1994), "Relationship Marketing: An Opportunity to develop a more vable marketing framework", in: Sheth, JN. en Parvatiyar, A. (eds.), Relationship marketing: Theory, Methods and Applications, 1994 Research conference proceedings, Ennory University, Atlanta

CRONBACH, L.J. (1951), "Coefficient Alpha and the internal structure of tests", Psychomerrika, jrg. 16. pp. 297-324

CROSBY, L.A. en Cowles, D. (1985), Consumer Atindes Tonard Whole Life Insurance (Have 2), Life Office Management Association, Allanta

CROSBY, L.A. en Stephens, N. (1987), "Effects of Relationship Marketing on Satisfaction, Retention. and Prices in the Life Insurance Industry", Joumal of Marketing Research, jrg. 24, no. November, pp. 404-411

CROSBY, L.A., Evans, K.R. en Cowles, D. (1990), "Relationship Quality in Services Selling: An Interpersonal Influence Perspectiwe", Journal of Marketing, jrg. 54, no. 3 (July), pp. 68-81

CUMBY, J.A. en Barnes, J.G. (1996), "Relationship Segmentation: The Enhancement of Databases to Support Relationship Marketing", in: Parvatiyar, A. en Sheth, JN. (eds.), Comernporary Knowledge of Relanonship Marketing, 1996 Research Conference Proceedings, Center for Relationship Marketing, Emory University, Atlanta, pp. 1.4.24

CZEPIEL, J.A. (1990), "Managing Relationships with Customers: A Differentiating Philosophy of Marketing", in: Bowen, D.E., Chase, R.B. en Cummings, T.G. (eds.), Semyice Managrement Effectiveness: Balancing Strategy. Organizaiion, and Human Resources, Josscy-13ass Publishers, San Francisco 
$\mathbf{D}$

DAY, G.S. en Wensley, R. (1983), "Marketing Theory with a Strategie Orientation", Journal of Marketing jrg. 47, Fall, pp. 79-89

DENIZE, S. en Young, L. (1996), "Measuring Commitment in Business Service Relationships", in: Sheth, J.N. en Sollner, A. (red.), Development, Management and Governance of Relationships, International Conference on Relationship Marketing, 29-31 maart 1996 te Berlin, pp. 169-174.

DHALLA, N.K. en Yuspeh, S. (1976), "Forget the Product Life Cycle Concept", Harvard Business Rewiew, January-February, pp. 102-112

DICK, A.S. en Basu, K. (1994), "Customer Loyalty: Toward an lintegrated Conceptual Framework", Jotmal of the Academy of Marketing Science, jrg. 22, no. 2, pp. 99-113

DLLER, H. (1994), Beziehungsmanagement tud Konsumentenforschung. Arbeitspapier Nr. 32, Universitat Erlangen-Nümberg, Betriebswirtschaftliches Institut

DILLER, H. (1997a), "Was leisten Kundenclubs?: Ein Testbeispiel", Marketing: Zeitschrift fiur Forschung und Praxis, jrg. 19, no. 1 (1. Quartal), pp. 33-41

DILLER, H. (1997b), "What Do Customer Clubs Achieve? - A Case Study", in: Meenaghan, T. (ed.), New and Evolving Paradigms: The Emerging Future of Marketing, Proceedings of Three Americian Marketing Association Special Conferences, 12-15 June 1997, Dublin, Ireland, pp. $241-253$

DILLER, H. (1997c), Preis-Management im Zeichen des Beziehungs-Markering, Arbeitspapier Nr. 52 . Universität Erlangen-Nürnberg, Betriebswirtschaftliches Institut

DILLER, H. en Kusterer, M. (1988), "Beziehungsmanagement." Theoretische Grundlagen und exploratieve Biefunde", Zeitschrift fuir Forschung und Proxis, jrg. 10, no. 3, pp. $211-220$

DILLER, H. en Frank, F. (1996), Ziele und Zielerreichungen non Kundenchbs; Ein Fallbeispiel aus den Moforradfachhandel, Arbeitspapier Nr. 45, Universität Erlangen-Nürnberg, Betriebswirtschaftliches Institut

DONNELLY, J.H., Jr., Berry, L.L. en Thompson, T.W. (1985), Marketing Financial Services - A Sirategic Vision, Dow Jones-Irwin, Homewood, Ill, p. 113

DOWLING, G.R. en Uncles, M. (1997), "Do Customer Loyalty Programs Really Work?", Sloan Management Review, Surnmer, pp. 71-82

DWYER, F.R., Schurr, P.H. en Oh, S. (1987), "Developing Buyer-Seller Relationships", Journal of Marketing, jrg. 51, april, pp. 11-27

DWYER, F, R. en Oh, S. (1987), "Output Sector Munificence Effects on the Intemal Political Econony of Marketing Channels", Journal of Marketing Research, jrg. 24, no. November, pp. 347-358

$\mathbf{E}$

EHRENBERG, A.S.C., Hammond, K. en Goodhardt, G. (1994), "The After-Effects of Price-Related Consumer Promotions", Journal of Adverising Reseaxch, jrg. 34, no. July-August, pp. 1 1-21

$\mathbf{F}$

FERGUSON, I.M. en Brown, S.W. (1991), "Relationship Marketing and Association Managemen", Journal of Professional Services Markering, jrg. 7, no. 2, pp. 137-147

ILETCHER, K., Wheeler, C. en Wright, J. (1991), "Database Marketing: A Channel, a Medium, or a Strategic Approach?", Intemational Joumal of Advertising, jrg. 10, pp. 117-127

FLOOR, J.M.G. en Raaj, W.F. van (1993), Marketingcommunicatie Siraiegie, tweede druk, Houten, Stenfert Kroese 
FOEKENS, E.W. (1995), Scanner Data Based Marketing Modelling: Enpirical Applications. proefschrift, $\mathbb{R}$ ijksuniversiteit Groningen

FORD, J.K., MacCallum, R.C. en Trait, M. (1986), "The Application of Exploratory Factor Analysis in Applied Psychology: A Critical Review and Antysis", Personnel Psychology.jrg. 39, pp. 291 314

FORNELL, C. (1992), "A National Customer Satisfaction Barometer: The Swedish Expertence". Journal of Marketing, jrg. 56, no. 1 (January), pp. 6-21

FRAZIER, G.L., Spekman, R.E en O'Neal, C.R. (1988), "Just-In-Time Exchange Relationships in Industrial Markets", Jownal of Marketing, jrg. 52, no. 4 (October), pp. $52-67$

Q

GANESAN, S. (1994), "Determinants of Long-Term Orientation in Buyer-Seller Revationships", Journal of Marketing, jrg. 58, no. 2 (April), pp. 1-19

GASKI, J.F. (1986), "Interrelations Among a Channel Entity"s Power Sources: Impact of the Exercise of Reward and Coercion on Expert, Referent, and Legitimate Power Sources", Jownal of Marketing Research, jrg. 23, no. February, pp. 62-77

GELDERMAN, C.J. en Tuninga, R.S.J. (1998), "Paradigmawisseling in marketing?", Bedriffkhinde. Tijdschrift voor modern management, jrg. 70, no. 1, pp. 89-97

GEYSKENS, I. en Steenkamp, J.-B.E.M. (1995), "Am Investigation into the Joint Effects of Trust and Interdependence on Relationship Commitment", in: Bergadaà, M. (red.), Proceedings of the $24 h$ EMAC Conference, Essec "Cergy-Pontolse, pp. 351-371

GEYSKENS, I., Steenkamp, J.-B.E.M., Scheer, L.K. en Kunar, N. (1996)" "The effects of trust and interdependence on relationship commitment: A trans-Atlantic study", Intermational Journal of Research in Marketing, jrg. 13, pp. 303-317

GEYSKENS, I. en Steenkamp, J.-B.E.M. (1997), "De rol van vertrouwen bij het opbouwen van langetermijn-relaties in de dienstensector", $M A B$, april, pp. 164-170

GISCHLER, C. (1988a), "Marketingcommunicatie en informatica", in: Molenaar, C.N.A. (red.), Handboek Direct Marketing: Niewwe trends en technologieën in (Direct) Marketing, Samsom, Alphen aan den Rijn/Brussel, pp. A1000-1-A1000-5

GISCHLER, C. (1988b), "De rol van direct marketing birmen de marketing", in: Molenaar, C.N.A. (red.), Handboek Direct Marketing. Nieuwe trends en technologieen in (Direct) Marketing, Samsom, Alphen aan den Rijn/Brussel, pp. A1030-1 en A1030-2

GOLDBERG; B. (1988), "Relationship Marketing", Direct Marketing, Odober, pp. 103-105

GREEN, P.E., Tull, D.S, en Albaum, G. (1988), Resecarch for Marketing Decisions, 5th, ed., New Jersey, Prentice Hall

GRÖNROOS, C. (1989), "Defining Marketing: A Market-Oriented Approach", Europun Jounal of Marketing, jrg. 23, no. 1, pp. 52-59

GRÖNROOS, C. (1990a), "Relationship Approach to Marketing in Service Contexts: The Marketing and Organizational Behavior Interface", Journat of Business Research, jrg. 20, no. 1 (January), pp. 3-11

GRONRROOS, C. (1990b), Sevvice Management and Marketing: Managing the Montents of Thath in Serwice Conpetirion, Lexington Books, DC Heath, Lexington, MA, pp. 125-153

GRÖNROOS, C. (1994a), "From Marketing Mix to Rellationship Marketing: Towards a Paradigm Shif in Marketing", Management Decision, jrg. 32, no. 2, pp. 4-20

GRÖNROOS, C. (1994b), "Quo Vadis, Marketing? Toward a Relationship Marketing Paradigm", Journal of Marketing Management, jrg. 10, no. 5, pp. 347-360

GRUEN, T.W. en Ferguson, J.M. (1994), "Using Membership as a Marketing Tool: Issues and Applications", in: Sheth, JN. en Parvatiyar, A. (eds.), Relationship Marketing: Theory, Methods and Applications, 1994 Research conference procedings, Emory University, Allanta 
GUMMESSON, E. (1987a), Marketing - A Long Term Imemactive Relationship: Contributions to a New Marketing Theory, Marketing Technique Center, Stockholm, Sweden

GUMMESSON, E. (19876), "The New Marketing - Developing Long-Term Interactiwe Relationships", Long Range Planning, jrg. 20, no. 4, pp. 10-20

GUNDLACH, G.T., Achrol. R.s. en Mentzer, J.T. (1995), "The Structure of Commiment in

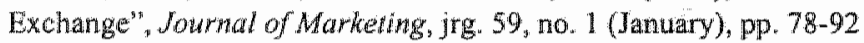

\section{$\mathbf{H}$}

HAIR, J.F. jr., Anderson, R.E., Tatham, R.L. en Black, W.C. (1995), Wultivariate Data Analysis With Readings, 4th. ed., Prentice-Hall, Englewood Cliffs, New Jersey

HAKANSSON, H. (red) (1982), International Marketing and Purchasing of Industrial Goads: An Interaction Approach, John Wiley and Sons, Chichester

HANSEN, U. en Jeschke, $K$. (1992), "Nachkaufmarketing: Ein neuer Trend im Konsumgütermarketing?", Zeirschrift fir Forschung und Praxis, jrg. 14, no. 2 (II Quartal), pp. 88-97

HEIDE, J.B. en John, G. (1992), "Do Norms Matter in Marketing Relationships?", Journal of Marketing, jrg. 56, no. April, pp. 32-44

HENNING, T. (1996), "Beziehungsqualität, Kundenzufriedenheit und mehr im Zentrum des Bezielnungsinarketing", Markforschung und Management, no. 4, pp. 142-148

HINDE, R.A. (1979), Towards understanding relationships, Academic Press, Londen

HOEKSTRA, J.C. (1993), "Strategische kanalalbeslissingen: Direct marketing en directe distributie", Markir, jrg. 3, no. 3 (oktober), pp. 14-18

HOEKSTRA, J.C. (1994a), Direct Marketing: van respons tot relatie, inaugurele rede Erasmus Universiteit Rotterdam, Wolters-Noordhoff, Groningen

HOERSTRA, J.C. (1994b), "Het strategisch belang van direct marketing op B-to-B markten", DM zakboek 95, Beerens Business Press, Woerden, pp. 13-23

HOEKSTRA, J.C. (1995a), "Direct Marketing en directe relaties", in: Postma, P. en Van Bel, EJ. (red.), Handboek Direct Marketing, Samsom, Alphen aan den Rijn, 1994, pp. A.1200.1A1200.18

HOEKSTRA, J.C. (1995b), "Direct Marketing: relaties door interactie", Maandblad voor Accounancy en Bedriffseconomie, jrg. 69, no. 12 (dec.), pp. 786-794

HOEKSTRA, J.C (1998), Direct marketing, tweede druk, Wolters-Noordhoff, Groningen

HOEKSTRA, J.C. en Leeflang, P.S.H. (1987a), "Algemene marktonstandigheden", in: De Direct Mait demonstratie-campagne wan PTT Post, "s-Gravenhage, deel 2, pp. 27-48

HOEKSTRA, J.C. en Leeflang, P.S.H. (1987b), "Organisatiestrategieën en Direct Marketing", in: De Direct Mail demonstratie-campagne van PTT Post, 's-Gravenhage, deel 3

HOEKSTRA, J.C. en Raaijmakers, M.C. (1991), "Betekenis en groei van direct marketing", Maandblad voor Accouniancy en Bedrijfeconomie, jrg. 65, no. 7/8 (juli/augustus), pp. 363.372

HOEKSTRA, J.C. en Raaijmaakers, M.C. (1992), "Definitie en plaatsbepaling van direct marketing", Tijdschrift wor Marketing. jrg. 26, no. 3 (maart), pp. 16-23

HOEKSTRA, J.C. en Schijns, J.M.C. (1996). "There is No Need for More than One Definition of Direct Marketing", Reseanch Memorandum RM/96/001, Meteor, Rijksuniversiteit Limburg

HOEKSTRA, J.C. en Schijns, JM.C. (1998), "Direct Marketing", leereenheid 22 van de cursus Marketing Management, Open Universiteit Nederland, Heerlen, pp. 138-187

HOLZ, S. (1998), "Die Kundenkarte als Instrument zur Kundenbindung im deutschen Einzelhandel", Direkt Marketing, no. 4, pp. 20-24

IOLZHAUER, F.F.O. en Zeitsen, O.D.A. (1993a), "Ontwikkelingen in de marketing (2)", Tijdschrift voor Marketing, jrg. 27, no. 6(juni), pp. 39-41

HOLZHAUER, F.F.O. en Zeitsen, O.D.A. (1993b), "Ontwikkelingen in de marketing (3): de exteme omgeving", Tijdschrift voor Marketing, jrg. 27, no. 10 (oktober), pp. 64-67 
HOLZHAUER, F.F.O. en Zeitsen, O.D.A. (1993c) "Ontwikkelingen in de markering (4): de exteme omgeving", Tijdschrifi woor Marketing, jrg. 27, no. 11 (november), pp. 45-48

HOLZHAUER, F.F.O. en Zeitsen, O.D.A. (1993d), "Waar komen we vandasan en war gaan wie heen?", in: Boomsma, S. (eindred.), NMA Markering Jaarboek, Kuwer, Deventer, pp. $74-82$

HONIG, C. (1990), "Im Dauerdialog mit der Zielgruppe", DirekM(arketing, no. 10 (Oktober), pp. 2022

HOOPER, M. (1997), "Is there no such thing as loyalty?", Admap, July/August, pp. 35-38

HOUSTON, F.S. en Gassenheimer, J.B. (1987), "Marketing and Exchange", Jownal of Marketing, jrg. 51, no. 4 (October), pp. 3-18

J

JACKSON, B.B., (1985), "Build Customer Relationships That Last", Harvard Business Review, jrg. 63. Nowember/December, pp. 120-128

JACKSON, B.B., (1986), "Duurzame relaties tussen afnemers en bedrijven", Harnard Hollond Review; no. 6 (voorjaar), pp. $118-126$

JACKSON, D. (1989), "Determining a Customer's Li fetime Value", Direct Marheting, jrg, 51, maart, pp. 60-62

JOHN, G. en Reve, T. (1982), "The Reliability and Validity of Key Informant Data From Dyadic Relationships in Marketing Channels", Journal of Marheting Research, jrg. 19, no. November, pp. $517-524$

$\mathbf{K}$

KAISER, H.F. (1958), "The varimax criterion for analytic rotation in factor" analysis", Psychomefrika, jirg. 23, pp. 187-201

KANI, G.K. (1993), 100 Statistical Tests, SAGE, London

KAPFERER, J.-N. (1996), Strategisch Merkmamagenten: over het eigen vermogen wan merken. tweede editie, Academic Service, Schoonhoven

KATZENSTEIN, H. en Sachs, W.S. (1992), Direct Marketing, tweede druk, MacMillan, New York

KAUFMANN, P.J. en Stern, L.W. (1.988), "Relational Exchange Norms, Perceptions of Unfaimess, and Retained Fostility in Commercial Litigation", Joumal of Conflict Rewolution, jrg. 32, no. 3, pp. $534-552$

KELLEY, S.W. en Davis, M.A. (1994), "Antecedents to Customer Bxpectations for Service Recovery", Journat of the Academy of Marketing Science, jrg. 22, no. 1 (Winter), pp. $52-61$

KOOIKER, R, en Heuvel, $T$. wan den (1992), Marktonderzoek, wiende druk, Wolters-Noordhoff, Groningen

KOOPMANS, F, en Jochems, J. (1996), "Van acquisitie naar retentie: Houd de klant!" Tijdschrift wor Marketing, jrg. 30, no. 12 (december), pp. $22-24$

KOOPMANS, F, en Jochems, J. (1997), "Iedere klant cen eigen sanpak", Tujdschriff voor Marketing, jrg. 31, no. 1 (januari), pp. $41-43$

KOTLER, P. (1988), Markethg Management: analysis, planning, implementation, and control, 6th. ed. Prentice-Hall, Englewood Clliff, NJ

KOTLER, P. (1992), "The five levels of relationship", Marketing News, jrg. 26, p. 21

KOTLER, P. (1994), Markefing Management amalysis, planning, implewentation, and control, 8 th. ed. Prentice-Hall, Englewood Cliffs, NJ, pp. 35-60

KOTLER, P. (1996), Marketing Management: analysis, planning, implementation, and control, 9 th. ed., Prentice-Hall, Englewood Cliffs, NJ 
KRAPFEL Jr., RE., Salmond, D. en Spekman, R. (1991), "A Strategic Approach to Managing BuyerSeller Relationships", European Joumal of Marketing, jrg, 25, no. 9, pp. 22-37

KREUTZER, R.T. (1990), "Die Basis für den Dialog", Absarwintschafi, no. 4, pp. 104-113

KROEZEN, T. (1998), "Khantenbinding: marketing tool of strategisch doel?", Tudschrift wor Markering.jrg. 32, no. 5 (mei), pp. $34-37$

KUIUPEES, R.J.C. (1998),

KUMAR, N., Scheer, L.K. en Steenkamp. J.B.E. (1995a), "The Effects of Supplier Faimess on Vunerable Resellers", Journal of Mawketing Research, jrg. 32, February, pp. 54-65

KUMAR, W. Scheer, L.K. en Steenkamp, JB.E.M. (1995b), "The Effects of Perceived Interdependence on Dealer Attitudes", Jounal of Marketing Research, jrg. 32, August, pp. 348356

L

LABARBERA, P.A. en Mazursky, D. (1983), "A Longitudinal Assessment of Consumer Satisfaction/Dissatisfaction: The Dynamic Aspect of the Cognitive Process", Jound of Marketing Research, no. November, pp. 393-404

LAGACE, R.R., Dahlstrom, R. en Gassenheimer, J.B. (1991), "The Relevance of Ethical Salesperson Behavior on Relationship Quality: The Pharmaceutical Industry", Joumal of Personal Selling \& Sales Management, jrg. 11, no. 4 (Fall), pp. 39-47

LAKATOS, P.A.M. en Kralingen, R.M. van (1985), Naar 1990: een kwestie wan lijd en geld. Verandering van de Nederlandse samenleving in 45 irends, Elsevier, Amsterdam/Brussel

LEEFLANG, P.S.H. (1986), "Belang van strategische markeing neemt toe", Harvard Holland Review, no. $6 . \mathrm{pp} .107-117$

LEEFLANG, P.S.H. en Beukenkamp, P.A. (1981), Probleengebied marketing, een managenewbenadewing, Stenfert Kroese, Leiden/Antwerpen

LEVITT, T. (1983a), "Alter the sale is over ...", Harvard Business Review, jrg. 61, no. 5 (September/October), pp. 87-93

LEVITT, T. (1983b), The Marketing Imaginarion, The Free Press, New York

LILJANDER, V. en Strandwik, T. (1994), "The Nature of Relationship Quality", paper, in: EIASMworkshop on Quality Management in Senices. $W$, Proceedings-Part II, Marne-La-Vallee, France, May 12-13

\section{M}

MALHOTRA, N.K. (1996), Marketing Research: An Applied Orientation, 2nd. ed, Prentice-Hall, New Jersey

MARKETNG NEWS (1985), "AMA Board approves new marketing definition", jirg. 19, I maart, p. 1.

MATHEU, IE. en Zajac, D.M. (1990), "A Review and Meta-Analysis of the Antecedents, Correlates, and Consequences of Organizational Commitment", Psychological Bulletin, jrg. 108, no. 2, pp. $171-194$

MoKENNA. R. (1991), Relationship maketing: successful strategies for the age of the customer, Addison-Wesley, New York

MEYCR, J.P. en Allen, N.ل. (1987), "Organizational Commitment: Toward a three component model", Research Bulletin No. 660, The University of Western Ontario, Department of Psychology, London

MITTAL, B. en Lee, M.S. (1988), "Seperating brand choise involvement from producer involvement via consumer involvenent profiles". Advances in Consumer Research, jrg. 15, pp. $36-40$ 
MTTTAL, B. en Lee, MS. (1989), "A causal model of consumer involvement", Jownal of howomic Psychology, jrg. 10. pp. 363-389

MOLENAAR, CN.A. (1993), Inieractieve marketing: het einde wan de massamarkenthg, Management Press, Amsterdan

MOLENAAR, CNA. (1994), "Interactieve marketing", Thdschrif woor Markeing, jrg. 28, no. 5 (mei), pp. 47-5.1

MOORMAN, C., Zaliman, G. en Deshpande, R. (1992), "Relationships Between Providers and Users of Marketing Research: The Dynamics of Trust Within and Between Organizations", Joturnat of Marketing Research, jrg. 29, no. August, pp. 314-329

MORGAN, R.M. en Hunt, S.D. (1994), "The Commitment-Trust Theory of Relationship Marketing", Joumal of Marketing, jrg. 58, no. 3 (July). pp. 20-38

MOWDAY, R.T., Steers, R.M. en Porter, L.W. (1979), "The Measurement of Otganizational Commitment", Joumal of Vocational Behavior, jig. 14, pp. 224-247

MOWDAY, R.T., Porter, L.W. en Steers, R.M. (1982), Employe-organizanional linkages, Academie Press, New York

MSI REVIEW (1991), "Philip Kotler Explores the New Marketing Paradigm", Spring, pp. 1, 4, 5

MURROW, J.L. en Hyman, M.R. (1994), "Direct Marketing: Passages, Defintion, and Déja Vu", Joumal of Direct Marketing, jrg. 8 , no. 3, pp. $45-56$

MUTERS, C.M.E. (1997), Informatietechnologie en klawenbinding: een relatie? doctoralscriptic Universiteit Maastricht, FdEWB, Maastricht

$\mathbf{N}$

NAERT, P.A, en Leellang, P.S.H. (1978), Building Implementable Marketing Models, Martinus Nijhoff Social Sciences Division, Leiden/Boston

NAUMANN, E en Shannon, P. (1992), "What Is Customer-Driven Marketing?", Business Hortzons, jrg. 35, no. 6 (November/December). pp. 44-52

NES, R. van, Machielse, I., en Rijn, $O$, van (1998), "Nieuwe wegen voor het meten wan loyaliteit", Onderzoek, jumi/julli, pp. 24-25

NUNNALLY, J.C. (1978), Psychomeric Theory, 2nd. ed, McGraw-Hill, New York

O

OTSMAA, M. en Greenberg, C.M. (1989), "Relationships offer lifetime walue, not just one-time trial", Marketing News,jrg. 23, 25 september, p. 16

\section{$\mathbf{P}$}

PALMER, A. (1994a), "Relationship Marketing: Time to Enrich the Marketing Curriculum?", Journal of Marketing Education, Summer, pp. 34.41

PALMER, A. (1994b), "Relationship Marketing: Back to Basics?", Joural of Markering Management, jrg. 10, no. 7, pp. 571.579

PARASURAMAN, A., Zeitham, V.A. en Berry, L.L. (1985), "A Conceplual model of service quality and its implications for future research", Joumal of Marketing, jrg. 49, no. 4, pp. 4li-50

PARVATIYAR. A. en Sheth, JN. (1994), "Paradigm shift in marketing theory \& approach: the emergence of relationship marketing", in: Sheth, JN. en Parvatiyar, A. (cds), Relationship marketing: Theory. Methods and Applications, 1994 Research conference proceedings, Fnory University, Atlanta 
PAME, A., Christopher, M. Clark, M. en Peck, H. (1995), Relationship Marketing for Cowpetitive Advaniage: Winning and kesping custamers, Butterworth/Heinemann, Oxford

PEELEN, E. (1989a), "Veranderende relaties in de marketing", in: Wierenga, B. (red.), Marketimg Informatiesystemen in de praktijk, studiedag te Eindhoven d.d. 4 oktober, Studiecentrum voor Bedrif en Overheid

PEELEN, E. (1989b), Relaties 1 wssen consmen en aanbieder: Een basis voor herhalingsaankopen, proefschrift, Haveka Alblasserdam

PEELEN, E. (1990a), "De relatielevenscyclus van consumenten. Uitgangspunt woor het relatiemanagement in consumentenmarkten", in: De Kracht van het Conract, de lezingen van het NIMA Marketing Congres '90, pp. 191-195

PEELEN, E. (1990b), "De aanbieder in het voetspoor van de consument: relatiemanagement in consumentenmarkten", Tifdschrift woor Marketing, jrg. 24, no. S (mei), pp. 9-17

PEELEN, E. (1991), "Relaties tussen consument en aanbieder: een basis voor herhalingsaankopen", in: Bronner, A.E. (red.), Recente ontwikkelingen in het marktonderzoek, jaarboek '91-'92 van de NVuM, de Vrieseborch, Haarlem, pp. 168-187

PEELEN, E., Ekelmans, C.F.W. en Wijn, P. (1987), Relatiemarketing doar Middel wan Direct Marketing, Lester Wunderman Instituut, Amsterdam

PEELEN, E., Ekelmans, C.F.W. en Vijn, P. (1989), "Direct Marketing for Establishing the Relationships Between Buyers and Sellers", Joumal of Direct Marketing, jrg. 3, no. 1 (Winter), pp. $7-14$

PELSMACKER, P. De en Kenhove, P. Van (1994), Marktonderzoek: Methoden en toepassingen, Garant, Leuven/Apeldoom

PEPPERS, D. en Rogers, M. (1993), The One to One Future: Building Relationships One Cusioner at a Time, Currency Doubleday, New York

PETER, S.I. (1998), "Kundenbindung als Marketingziel", Absatzwirtschaft, no. 7, pp. 74-81

PETERSON, R.A. (1995), "Relationship Marketing and the Consumer", Journal of the Academy of" Marketing Science, jrg. 23, no. 4 (Fall), pp. 278-281

PETROF, J.V. (1997), "Relationship Marketing: The Wheel Reinvented?" "Business Horizons" no. November-December, pp. 26-31

POIESZ, T.B.C. en Van Raaij, W.F. (1993), "A Psychological Approach to Relationship Quality in Industrial Markets", Papers on Economic Psychology, no. 117, Erasmus Universiteit, Rotterdam

PORTER, M. (1980), Competitive Sirategy: Techniques for Analyzing Industries and Competitors, The Free Press, New York

PORTER, M. (1985), Compertive Adwanage, Techniques for Creating and Sustaining Superior Performance, The Free Press, New York

PORTER, L.W., Steers, R.M., Mowday, R.T. en Boulivan, P.V. (1974), "Organizational Commitment, Job Satisfaction, and Tumover among Psychiatric Technicians", Journal of Applied Psychology, jrg. 59, no. 5, pp. 603.609

$\mathbf{R}$

REICHHELD, F.F. (1996), The Loyalty Effect: The Hidden Force Behind Growth, Profits, and Lasting Value, Harvard Business School, Boston

REICHHELD, F.F. en Sasser Jr., W.E. (1990), "Zero Defections: Quality Comes to Services", Harvard Business Review, september-oktober, pp. 105-111

ROOMER, J. (1990a), DM: Theorie, methoden en techmeken wan direct marketing, Samsom. Alphen aan den Rijn/Deurne

ROOMER, J. (1990b), "Verwarting rond direct marketing", Tujdschrift voor Marketing, jig. 24, no. 10 (oktober), pp. 25-33

ROOMER, J., Bouten, H. e.a. (1982), Handboek Direct Marketing, Kluwer, Deventer, 1982-1985 
ROSENBERG, L.J. en Czepiel, J.A. (1984), "A Marketing Approach for Customer Retention", The Joumal of Consumer Marketing, jrg. 1, pp. 45-51

ROWE, C.W. (1989), "A Rewiew of Direct Marketing and How it can be Applied to the Wine Industry", European Jownal of Marketing, jrg. 23, pp. 5-14

RUEKERT, R.W. (1992), "Developing a Market Orientation: an Organizational Strategy Perspective", International Jowmal of Research in Marketing, no. 9, pp. 225-245

RUYTER, K. de, Wetzels, M. en Thijssen, M. (1997), "Wan accountant naar accountmanager". MAB, jrg. 71 , no. 10, pp. $531-541$

$\mathbf{S}$

SAMPATHKUMARAN, S. (1994), "Migration analysis helps stop customer attrition", Marketing News, Aug. 29, pp. 18-19

SANDVIK, K., Grönhaug, K. en Lindberg, F. (1997), "Routes to Customer Retention: The Importance of Customer Satisfaction, Performance Quality, Brand Reputation and Customer Knowledge", in: LeClair, D.T. en Hartline, M. (red.), 1997 AMA Winter Educators" Conference: Marketing Theory and Applications, jrg. 8, Chicago, pp. 211-217

SCHIJNS, J.M.C. (1991), "Direct Marketing: basis voor heldere theorievorming", Tifdschrifl voor Marketing, jrg. 25, no. 9 (september), pp. 28-35

SCHIJNS, J.M.C. (1994), "De kracht van het contact: nieuwe impulsen voor relatiemarketing", Tijdschrift voor Marketing, jrg. 28, no. 10 (aktober), pp. $61-66$

SCHIINS, J.M.C. (1996a), "Klantenrelaties", hoofdstuk 28 in de Grondslagen, Marketing in Meervond, aflevering $S$, februari, Klwwer Bedrijfswetenschappen, Deventer

SCHIJNS, J.M.C. (1996b), "Measuring Relationship Strength for Segmentation Purposes", in: Parvatiyar, A. en Sheth, J.N. (eds.), Comemporary Knowledge of Relationship Marketing, 1996 Research Conference Proceedings, Center for Relationship Marketing, Emory University, Atlanta, pp. 25-31

SCHINNS, J.M.C. (1998), "The Impact of a Membership Program on Relationship Strength: results of exploratory research", in: Sheth, J.N en A. Menon (eds.), 1998 Research Conference Proceedings: New Frontiers in Relationship Marketing Theory and Practice, June 12-14, Emory University, Atlanta, Georgia, pp.

SCHINS, J.M.C. en Lemmink, J.G.A.M. (1994), "Consumer Relationships and Marketing Strategy", in: Bloemer, J, Lemmink, J.G.A.M. en Kasper, J.D.P. (eds.), Markering: Ifs Dywamics and Challenges, Proceedings, 23 rd EMAC ANNUAL CONEERENCE, The Netherlands, Matastricht. pp. $1439-1442$

SCHIJNS, J.M.C. en Schröder, G.J. (1996), "Segment Selection by Relationship Strughth", Jourmal of Direct Marketing, jrg. 10, no. 3 (Summer), pp. $69-79$

SCHLOSSBERG (1989), Marketing News, jrg. 23, 25 september

SCHOFIELD, A. (1995), "The Definition of Direct Marketing: A Rejoinder to Bauer and Miglautsch", Journal of Direct Marketing, jrg, 9, no. 2 (Spring), pp. 32-38

SCHOLTENS. A.I. (1996). The Association Between Global Corporate Philanthrophy and Customer Commitment: A Research at The Body Shop, doctoraalscriptie Universiteit Maastrichi, FdEWB, Maastricht

SCHRIVER, S. (1997), "Customer Loyalty: Going, Going ...", American Demographics, no. September, pp. 20-23

SCHROODER, G. (1994), Meien van relatie-sterkte in de consumentenmarki: literatumstudie on empirisch onderzoek, doctoraalscriptie, FdEW, Rijksuniversiteit Limburg, Maastricht

SCHÜRNG, H. (1991), Database Marketing: Einsaz von Datenbanken fïr Direktmarketing, Verkauf und Werbung, Verlag Moderne Industrie, Landsberg 
SCHURR, P.H. en Ozanne, J.L. (1985), "Influences on Exchange Processes: Buyers' Preconceptions of a Seller's Trustworthiness and Bargaining Toughness", Jounal of Consumer Research, jrg. 11. pp. 939.953

SHANI, D. en Chalabini, S. (1992), "Exploiting Niches Using Relationship Marketing", The Journal of Services Marketing, jrg. 6, no. 4 (Fall), pp. 43-52

SHARP, B. en Sharp, A. (1997), "Loyalty programs and their impact on repeat-purchase loyalty patters", Intemational Joumal of Research in Marketing, jrg. 14, pp. 473-486

SHETH, JN. (1993), "Relationship Marketing: An Emerging School of Marketing Though", proceeding, presented at the Winter Conference of the AMA, February

SHETH, J.N. en Parvatiyar, A. (1995), "Relationship Marketing in Consumer Markets" Antecedents and Consequences", Jow wal of the Academy of Marketing Science, jrg. 23, no. 4 (Fall), pp. 255271

SIRGY, M.J. en Lee, D.J. (1994), "Relationship marketing and beyond: a Quallty-of-life approach to consumer marketing", in: Sheth, J.N. en Parvatiyar, A. (eds.), Relationship marketing: Theory, Methods and Applications, 1994 Research conference proceedings, Emory University, Atlanta

SMEETS, Y. (1998), "Hoe werkoop je reizen direct? Bex Reizen over Direct Marketing", Customer Base, jrg. 4, no. 3, p. 19

SOLLNER, A. (1996), "Asymmetrical Commitment in Business Relationships", in: Sheth, J.N. en Sollner, A. (red.), Development, Managenent and Governance of Relationships, Intemational Conference on Relationship Marketing, 29-31 maart 1996 te Berlijn, pp. 175-176

SPEKMAN, R.E. (1988), "Strategic Supplier Selection: Understanding Long-Term Buyer Relationships" "Business Horizors, no. July-August, pp. 75-81

STAUSS, B. en Neuhaus, P. (1996), "Das Unzufriedenheitspotential zufriedener Kunden", Marktorschung und Management, no. 4, pp. 129-133

STEENKAMP, J.E.B.M. (1991), "Kwaliteit en 'customer relations", Tijdschriff woor Marketing, jrg. 25 , no. $\mathbb{1}$ (januari), pp. $40-48$

STONE, M., Woodcock, N. en Wilson, M. (1996), "Managing the Change from Marketing Planning to Customer Relationship Management", Long Range Planning, jrg. 29, no. 5, pp. 675-683

STORM, C.M. (1991), "Marketing: terug naar af?", Tijdschrift woor Marketing, jrg. 25, no. 11 (november), Pp. 144-152

STORM, C.M. (1992), "Marketing van binnen uit", Bedriffskunde, jrg. 64, no. 2, pp. 199-206

STRANDVIK, T, en Liljander, V. (1994a), "A Comparison of Episode Performance and Relationship Performance for a Discrete Service", paper presented at 3. Dienstleistungsmarketing-Workshop, 24-25 Feb., Berlin, Germany

STRANDVIK, T. en Liljander, V. (1994b), "Relationship Strength in Bank Services", in: Sheth, J.N. en Parvatiyan, A. (eds.), Relationship marketing: Theary, Methods and Applications, 1994 Research conference proceedings, Emory University, Atlanta

SWAN, J.E., Trawick, I.F. en Silva, D.W. (1985), "How Industrial Salespeople Gain Customer Trust", Industrial Marketing Managemen, jrg. 14, pp. 203-211

T

TAPP, A. (1998), Principles af Direct of Database Marketing, Pitman, London

TILLEMANS, M.M.E. (1998), Relatiemarketingprogramma's: Mofivatie vam consumenten voor lidmaatschap, doctoralscriptie Universiteit Maastricht, FdEWB, Maastricht

TREACA, M. en Wiersema, F. (1993), "Customer Intimacy and Other Value Disciplines", Hanard Business Review, no. January-February, pp. $84-93$

TURNBULL, P.W. en Valla, J-P. (1986), Strotegies for International Industrial Marketing, Croomhelm, London 
TURNBULL, P.W. en Wilson, D.T. (1989), "Developing and Protecting Profitable Customer Relationships", Industrial Marketing Managenen, jrg. 18, pp. 233-238

V

VAVRA, T.G. (1992), Aftermarketing: how to keep customers for life through relationship manketing, Business One Irwin, Homewood, Illinois

VENETIS, KA. (1997), Service Quality and Customer Loyalty in Professional Business Service Relationships: An empirical investigation into the customer-based service quality concept in the Duch adwertising industry, proefschrift, Universiteit Maastricht.

VERSTEEG, M. (1996a), "De klantenkaart: fenomenaal gemeengoed", Tijdschrift voor Markethg, jrg. 30 , no. 1/2 (januari-februari), pp. 16-18

VERSTEEG, M. (1996b), "Klantenkaarten", in: Postma, P. en Van Bel, E.J. (red.), Handboek Direct Marketing, Samsom, Alphen aan den Rijn, 1994, pp. B3300.1-B3300.12

W

WATERSCHOOT, W. van en Bulte, C. van den (1992), "The 4P Classification of the Marketing Mix Revisited", Joumal of Marketing, jrg. 56, no. 4 (October), pp. 83-93

WEBSTER, F.E. jT. (1992), "The Changing Role of Marketing in the Corporation", Journat of Marketing, jrg. 56, no. 4 (October), pp. 1-17

WEIERS, R.M. (1984), Marketing Research, Prentice-Hall, Englewood Cliffs

WILLENBORG, G.B.W. en Leeflang, P.S.H. (1997), "Relatiemarketing: een nadere beschouwing", $M A B$, september, pp. 441-454

WILLS, G. en Wills, J. (1992), "Journey to Marketing Clubland", Marketing Intelligence de Planning, jrg. 10, no. 2, pp. 22-36

WILSON, D.T. (1990), Creating and Managing Buyer-Seller Relationships, ISBM Report 5 1990, The Pennsylvania State University

WILSON, D.T. (1995), "An Integrated Model of Buyer-Seller Relationships", Journal of Academy of Marketing Science, jrg. 23, no. 4 (Fall), pp. 335-345

WILSON, D.T. en Mummalaneni, V. (1988), Modeling and measuring Buyer-Seller Relationships, ISBM Report 3-1988, The Pennsylwania State University

WULF, K. de en Vergult, Ch. (1997), "Trouw via klantenbindingssystemen: utopie of werkelijkheid", in: Herman, J. et al. (red.), Jaarboek CuromerBase 1998, pp. 95-107

$\mathbf{Y}$

YOUNG, L.C. en Denize, S. (1995), "A Concept of Commitment: Alternative Views of Relational Continuity in Business Service Relationships", Joumal of Business and Industrial Marketing, jrg. 10, no. 5, pp. $47-62$

Z

ZEITHAML, V.A. en Bitner, M.J. (1996), Services Markeing, McGraw-Hill, New York ZWART, P.S. (1994), Methadent van Marktonderzoek, vierde druk, Stenfert Kroese, Houten 


\section{SUMMARY}

\section{MeAsUring and MaNAGRG CUSTOMER ORGANISATION RELATIONSHIPS}

Changing market circumstances have led to a situation in which the traditional marketing mix approach is no longer adequate in all cases to achieve a sustaned competitive advantage. The efforts of marketing managers can no longer be directed merely at bringing in new customers. They will also have to pay attention to keeping existing customers. This appears to lead to more effective and efficient marketing and communication strategies. Keeping customers implies managing relationships. Relationship management, in tum, requires "relationship measurement", making the relationship concept measurable and applicable. In order to be able to evaluate the effects of measures that strengthen relationships, it is necessary to measure the strength of relationships (the degree of commitment) between consumers and organisations. The core question, which this study attempts to answer, is therefore:

How can we measure the strength of relationships (the degree of comminment) berween consumers and organisations?

To be able to answer the above question, three research questions have been defined:

1. What data provide an indication of the strength of a relationship between (end) user and supplier, and which of these can be used in operational terms to construct an instrument that can measure the strength of the relationship?

2. (How) can the measuring instrument for the strength of relationships be used to segment, describe and monitor relationships? And,

3. What factors play a role in the explanation of the strength of relationships?

This thesis focuses on the development of an instrument that can be used on the one hand to measure the strength of relationships, and on the other hand to make recommendations for the use of this instrument for management purposes (segmentation and control).

Chapters 2 and 3 outline the theoretical framework used for this research projoct. Chapter 4 approaches the three research questions from a theoretical point of view and presents the research models and hypotheses. The design and implementation of the empirical research are explained in Chapter 5 . Chapter 6 contains the analysis of the data set. Chapter 7 gives explicit answers 10 the three research questions, draws conclusions and discusses the implications and directions for further research.

Chapter 2 deals with the characteristics of transactions and transaction marketing on the onc hand, and of relations and relationship marketing on the other.

A pure transaction is defined as a one-off exchange of values between two parties, without any previous or subsequent interaction. In reality, pure transactions are rare and therefore abstract. They do, however, constitute the starting point of a continum for relationships and alliances, and hence create a useful starting point for theoretical analysis. A discrete transaction thus constitutes the basis on which a relationship can be built.

If the marketing activities concentrate on the ad hoc transaction and subsequent exchange of goods or services for money, with generally anonymous customers, we speak of twansaction markering. 
A relationship is defined as an interaction process that is controlled by both economic and noneconomic objectives, is direct, integrated, and applies to multiple transactions, taking place between a supplier and a consumer in connection with the purchase and use of household goods and services.

Relationship marketing is defined as an integrated effort to identify, maintain, and build up a network with individual consumers and to continuously strengthen the network for the mutual benefit of both sides, through interactive, individualised and value-added contacts over a long period of time.

Relationships can be analysed from a behaviour dimension and a perception dimension. These are centred, respectively, around the factual events and the subjective interpretation of these events. The distinction of a behaviour dimension and a perception dimension will be the primary starting point for research concerning the strength of relationships, because it is considered relevant in consumer markets to describe a relationship in terms of attitudes and behaviour of consumers.

Chapter 3 contains a strategic and instrumental implementation of the concept of relationship marketing.

Direct marketing is defined as a form of marketing, directed at establishing, maintaining, and enhancing direct relationships between a supplier and his customers within one (or more) product market combination(s). The marketing activities are based on knowledge of individual (potential) customers; the marketing instruments can be tailored to individual needs. The most distinctive features are the use of direct communication and/or direct distribution.

The connection between direct marketing and relationship marketing is that both have a similar effect, considering the efforts made to create individual relationships. Relationship marketing then indicates the concept on the basis of which activities are carried out, while direct marketing specifies such activities.

A relationship marketing programme is defined as a structured programme, consisting of a combination of marketing mix instruments, offering different advantages and rewards to (certain) customers in order to create an added value for the product or the service, the main objectives being: keeping customers, developing customers and strengthening relationships.

Customer clubs are a specific category of relationship marketing programmes. A cusiomer club is a fictitious association of purchase decision-makers from a particular target group, organised by one or more suppliers, with memberships being offered to customers with the aim of keeping in regular contact with them and to stimulate them. As a marketing instrument, customer clubs fit both within the framework of the relationship marketing concept and within a direct marketing strategy. This makes them eminently suitable for building up direct relationships with customers. It also renders such programmes eminently suitable for our empirical research aimed at measuring the strength of relationships.

Chapter 4 approaclies the three research questions from a theoretical perspective and describes the research models and hypotheses.

The strength of a relationship is defined as the strength of an individual"s identification with and involvement in a particular organisation. It was proposed to measure the strength of relationships using the relationship commitment scale, a version of the organisational commitment questionnaire that has been adlapted to the marketing context. This is because we believe that the domain of the construct, originating from the organisation literature, can be extended to include external 
relationships, such as those between suppliers of fast moving consumer goods and their customers. Applying the RLM model, the strength of relationships can be used to montor, classify and describe relationships. The RLM model (Relationship perception and Loyalty Matrix) can be compared to the product portfolio. But instead of products, relationships with customers are taken as the unit of analysis in the RLM model. An analysis of the RLM model provides insight in the possibilities of strengthening relationships with customers, influencing their purchasing behaviour, or both.

To give managers and scientists greater insight in the factors that may explain the strength of relationships with customers, a model is proposed. In this model, the strength of a relationship is made dependent on a number of antecedents that have emerged from research as being of fundamental importance for the development of relationships, i.e.: trust, switching costs, and attractiveness.

Chapter 5 explains the design and implementation of the two studies included in this research project. The method of data collection used was a "multiple study, multiple sample' approach. In practice, this meant that present, former and potential members of the Gulpener Beer Guild were approached in the first study. In the second study, present and former members of the Gall \& Gall Wine Pass Holder programme were interviewed. The sample frameworks were created by the NAW data files (containing names, addresses, and ZlP-codes) supplied by the participating organisations. Both studies made use of several independent, random, systematic samples. For each subgroup/set, a (disproportional) nett sample of approximately 250 respondents was taken. In the Gulpener study, 1,180 addresses were approached, yielding 758 respondents $(64 \%)$. For Gall \& Gall, 1,131 individuals were approached, which resulted in 500 respondents $(44 \%)$.

Chapter 6 presents the results of the empirical study. On the basis of the results of the data analysis, the following can be reported. It appears that the relationship commitment questionnaire (RCQ) can be used as reliable and walid scale to measure the strength of relationships between suppliers and their end users. It also appeared that the attitude component and the behaviour component represent substantially different dimensions in the relationships studied. Regression analyses yielded positive connections between "relationship strength" on the one hand and "atractiveness", "perceived switching costs" and "trust' on the other hand. It also appeared that this limited number of independent variables is capable of explaning a large part of the variance in the strength of relationships. The results of the two studies also suggest that a relationship is a dynamic process, although this dynamic process does not follow the same pattem in both studies.

In the Gulpener study, "tust" and "attractiveness" constitute the most fundamental explanatory variables, in the sense that these variables make a significant contribution to the explanation of the 'strength of the relationship' in all three subgroups. 'Switching costs' only do so among present and Cormer members. Apart from the fact that 'switching costs' do not make a significant contribution for each subgroup, the relative importance of the other influencing variables "trust" and 'attractiveness' also differs. For potential members and present members, "trust' makes the most significant contribution to the explanation of RC, followed by 'attractiveness". Among former members, the reverse is the case.

In the Gall \&, Gall study, in which two subgroups were analysed, "attractiveness", "switching cosis" and "trust" play a significant role among both present and former members. Among present members, the variance of RC is explained most by 'attractiveness', followed at some distance by 
"trust" and "switching costs', respectively. Among former members, the variable "attractiveness" also coniributes most to the explanation of the variance in $\mathrm{RC}$, but in this case it is followed by the variables 'switching costs" and 'trust', respectively.

A remarkable observation is the fact that among present members of the Gulpener Beer Guild, a certain 'basic' or 'minimum' level for RC may be necessary in order to become or remain a member of the Beer Guild. There is no indication for such a basic level among wine pass holders, which is plausible considering the (difference of the) nature and content of the two programmes.

In Chapter 7 , we return to the research questions formulated for this study. The main conclusions and implications are given for each question.

The main conclusion is that the RCQ meets a scientific and social need for an instrument that can measure the strength of relationships in a valid and reliable way.

Another conclusion is that customer relationships can be segmented, described and monitored by means of the RLM model. The dimensions of this model are the behaviour component and the attitude component that can be distinguished within a relationship. By operationalising the attitude dimension of this RLM model by means of the RCQ, greater insight is obtained in the composition of the customer base. Using the RLM model, customers can be described on the basis of transaction information on the one hand, and the strength of their relationships with the supplier on the other. Research has shown that the strength of the relationship is positively influenced by such factors as trust, attractiveness and switching costs. By regularly including (a representative sample of) the customer base in an RLM model, it is possible to monitor changes in the strength of relationships (and/or purchasing behaviour) and to analyse and deal with unfavourable developments in the composition of the customer portfolio. Using tailor-made service, communication, up-, cross- and deep-selling, witl or without a relationship marketing programme, the strength of relationships and purchasing behaviour can be led in the desired direction.

In addition to these main conclusions, a number of other findings are discussed, including the effects of relationship marketing programmes, with their theoretical and management implications. The chapter ends with a number of recommendations for further research. 


\section{CURriculum Vitae}

Jos Schijns werd op 13 mei 1961 geboren te Wijlre. Na het voltooien van het voorbereidend wetenschappelijk onderwijs, genoten van 1973 tot 1979, studeende hij aan het Hoger Economisch en Administratief Onderwijs tot 1982. Van 1984 tot 1988 studeerde hij bedrijfseconomie aan de Universiteit Maastricht, Faculteit der Economische Wetenschappen en Bedrijfskunde.

Na het voltooien van deze universitaire studie is hij gedurende tien jaar als docent verbonden geweest aan de Universiteit Maastricht. In 1998 is hij daarnaast werkzaan geweest als senior projectleider bij Branches \& Trends b.v. te Maastricht, een bureau woor marktonderzoek en opiniepeiling. Momenteel is hij als studiebegeleider werkzaam woor de Open Universiteit Nederland.

Jos Schijns maakt deel uit van de "werkgroep universiteiten' van de DMSA, de Nederlandse Associatie voor Direct Marketing, Distance Selling en Sales Promotion. Ook treedi hij regelmatig op als extern deskundige bij afstudeeropdrachten aan de Hogeschool 'sHertogenbosch en als spreker op congressen en seminars. 